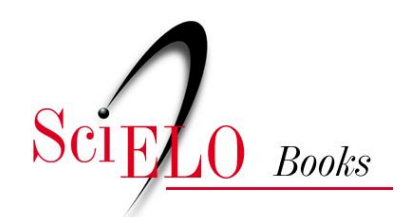

\title{
Seduepb
}

\section{Antropologia da comunicação de massa}

\author{
Isabel Travancas \\ Silvia Garcia Nogueira
}

(orgs.)

TRAVANCAS, I., and NOGUEIRA, SG., orgs. Antropologia da comunicação de massa [online]. Campina Grande: EDUEPB, 2016. Paradigmas da Comunicação collection, 307 p. ISBN 978-857879-332-6. Available from SciELO Books $<$ http://books.scielo.org $>$.

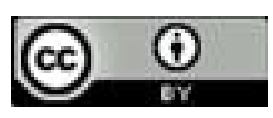

All the contents of this work, except where otherwise noted, is licensed under a Creative Commons Attribution $\underline{4.0 \text { International license. }}$

Todo o conteúdo deste trabalho, exceto quando houver ressalva, é publicado sob a licença Creative Commons Atribição 4.0.

Todo el contenido de esta obra, excepto donde se indique lo contrario, está bajo licencia de la licencia $\underline{\text { Creative }}$ Commons Reconocimento 4.0. 
Isabel Travancas

Silvia Garcia Nogueira

(Organização)

ANTROPOLOGIA DA

COMUNICAÇÃO DE MASSA
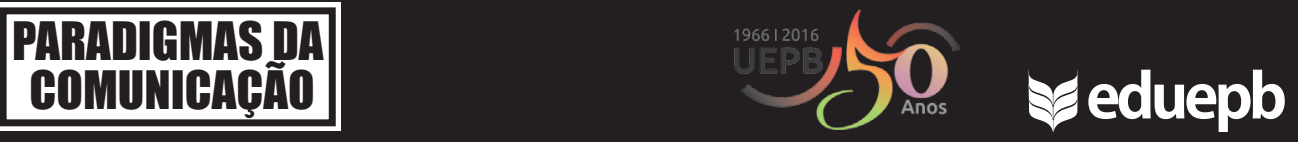
Editora da Universidade Estadual da Paraíba

Luciano do Nascimento Silva | Diretor

Antonio Roberto Faustino da Costa | Diretor-Adjunto

Conselho Editorial

Presidente

Luciano do Nascimento Silva

\section{Conselho Científico}

Alberto Soares Melo

Cidoval Morais de Sousa

Hermes Magalhães Tavares

José Esteban Castro

José Etham de Lucena Barbosa

José Tavares de Sousa

Marcionila Fernandes

Olival Freire Jr

Roberto Mauro Cortez Motta

\section{Coleção PARADIGMAS DA COMUNICAÇÃO}

Editor: Luiz Custódio da Silva

Editor Adjunto: Cidoval Morais de Sousa

Conselho Editorial

Antonio Roberto Faustino da Costa

Cidoval Morais de Sousa

Fernando Firmino da Silva

Isabel Travancas

Luiz Antonio Mousinho Magalhães

Luiz Custódio da Silva

Roberto Marden Lucena

Silvia Garcia Nogueira

Thiago Quiroga

Wellington Pereira

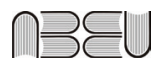

Editora filiada a ABEU 


\section{Isabel Travancas}

Silvia Garcia Nogueira

(Organização)

\section{ANTROPOLOGIA DA COMUNICAÇÃO DE MASSA}

\section{Geduepb}

Campina Grande - PB

2016 
Copyright $\odot$ EDUEPB

A reprodução não autorizada desta publicação, por qualquer meio, seja total ou parcial, constitui violação da Lei $n^{\circ}$ 9.610/98.

A EDUEPB segue o Acordo Ortográfico da Língua Portuguesa de 1990, em vigor no Brasil, desde 2009.

\section{Editora da Universidade Estadual da Paraíba}

Luciano do Nascimento Silva | Diretor

Antonio Roberto Faustino da Costa | Diretor-Adjunto

Design Gráfico

Erick Ferreira Cabral

Jefferson Ricardo Lima Araujo Nunes

Lediana Costa Frutuoso

Leonardo Ramos Araujo

\section{Divulgação}

Zoraide Barbosa de Oliveira Pereira

\section{Revisão Linguística}

Elizete Amaral de Medeiros

\section{Normalização Técnica}

Jane Pompilo dos Santos

A636 Antropologia da comunicação de massa [Livro eletrônico]./ Isabel Travancas; Silvia Garcia Nogueira (Organizadoras). Campina Grande: EDUEPB, 2016. (Coleção Paradigmas da Comunicação).

2400 kb. 308 p.

Modo de acesso: Word Wide Web <http://proreitorias. ascom.uepb.edu.br/prograd/?page_id=655

\section{ISBN 978-85-7879-256-5}

ISBN EBOOK 978-85-7879-263-3

1. Comunicação. 2. Antropologia. 3. Mídia - televisãoconsumo. 4. Meios de comunicação. I. TRAVANCAS, Isabel. II. NOGUEIRA, Silvia Garcia. III. Título.

21 ed. CDD. 


\title{
Nota dos Editores
}

\author{
A Coleção PARADIGMAS DA COMUNICAÇÃO \\ tem como foco estudos que contemplem a \\ comunicação social e midiática como constituinte \\ da sociabilidade contemporânea, a partir de \\ abordagens teóricas múltiplas dos diferentes campos \\ de conhecimento.
}




\section{Sumário}

A Comunicação de Massa no campo da Antropologia

Isabel Travancas

Silvia Garcia Nogueira

Da mediação à punição: visões e confrontos do consumo entre classes em um seriado de TV

Carla Barros

Já vale tudo? Dilemas éticos e suas representações midiáticas em tempos de paradigmas deslizantes 51 Ana Lucia Enne

Jovens rurais e as desigualdades sociais do campo representadas no Jornal Nacional 69 Julia Schnorr

A crônica como um espaço itinerante da cidade 95 Jeana Laura da Cunha Santos

"Afinal de contas, autoajuda funciona ou não?": apontamentos sobre o estudo antropológico de produtos culturais 
Imagens juvenis no cinema brasileiro contemporâneo

Janie k. Pacheco

High school cinematográfica: juventude, consumo

e popularidade nos filmes de John Hughes

César Cundari da Rocha Santos

Lennita Oliveira Ruggi

Marcelo Francisco

Democracia en imágenes. Fantasmas y esperanzas

en los relatos electorales de la Argentina

contemporánea (1983-2011)

191

Mercedes Calzado

Manchetes assustadoras: a construção social do medo entorno de um caso de violência sexual 219

Jimena Maria Massa

Visões de um quase acontecimento:

desenvolvimento, sustentabilidade e as disputas de

sentido no debate midiático sobre Belo Monte 251

Luciana de Oliveira

As estratégias da Secom/PR e a construção de uma identidade brasileira no âmbito internacional. 283

Silvia Garcia Nogueira

Sobre os autores 


\section{A Comunicação de Massa no campo da Antropologia}

Isabel Travancas

Silvia Garcia Nogueira

\section{Introdução}

Há mais de dez anos, quando começaram a surgir os primeiros Grupos de Trabalho ou Seminários Temáticos sobre Comunicação de Massa nos Congressos da área de Ciências Sociais, mais especialmente na Antropologia, não se poderia imaginar o quanto esse campo iria crescer e ser uma presença nos eventos futuros. E é um pouco sobre essa história que gostaríamos de falar.

A grande referência para os estudos sobre a Indústria Cultural e os meios de comunicação de massa, durante muito tempo, foram os trabalhos da chamada Escola de Frankfurt, especialmente a obra de Theodor Adorno, Max Horkheimer e Walter Benjamin. Eles não só produziram uma reflexão original sobre essa indústria e seus produtos como deram a ela um status de objeto legítimo de pesquisa. Adorno e Horkheimer (1991) com seu texto clássico "A Indústria Cultural: o esclarecimento como mistificação das massas" estavam preocupados em entender como a cultura tinha se transformado 
em produto e todos eram forçados a passar pelo filtro da indústria cultural. Nela, não há lugar, segundo eles, para a crítica nem para o respeito. Uma visão bastante radical, classificada como "apocalíptica” por Umberto Eco (1998), em seu também importante ensaio sobre a indústria cultural. Essas fontes foram essenciais para a construção de um espaço de reflexão sobre os meios de comunicação de massa dentro da Antropologia.

A Escola de Chicago, com seus estudos sobre a cidade, seus habitantes e seus estilos de vida foi outra corrente fundamental por olhar a questão urbana sob um novo prisma e demonstrar que a Antropologia não precisava apenas estudar povos exóticos e distantes. O trabalho de Robert Park (2008, p.51-70) é relevante não só pelo fato de ele ter sido jornalista e enfatizado a influência dessa experiência na sua formação, mas por procurar ver "as notícias como forma de conhecimento" destacando inclusive que "no mundo moderno o papel da notícia tem assumido maior importância em comparação com outras formas de conhecimento, a história, por exemplo" (PARK, 2008, p.70). E para o autor, o surgimento do repórter pode ser considerado um dos mais importantes eventos da sociedade norte-americana.

Dentro de um contexto mais contemporâneo de reflexão sobre os meios de comunicação de massa, os trabalhos de duas antropólogas norte-americanas se destacam. São elas Debra Spitulnik e Lila Abu-Lughod.

Spitulnik é professora da Emory University e escreveu uma tese de doutorado sobre a rádio na África. Sua resenha sobre a interseção da Antropologia com a Comunicação, publicada em 1993, no Annual Review of Anthropology, chama a atenção para o fato de ainda, naquela época, não ser possível falar em uma "antropologia dos meios de comunicação de massa”, embora, na última década, tenha havido um aumento do interesse em estudá-los. Segundo a 
antropóloga, há inúmeras maneiras de se abordar antropologicamente os meios de comunicação de massa: como instituições, como lugares, como práticas comunicativas, como produtos culturais, como atividades sociais, como formas estéticas e como desenvolvimentos históricos.

Abu-Lughod é professora da Columbia University e vem estudando questões de gênero, cultura e política no contexto da sociedade egípcia. Ela é uma dos organizadores do livro Media worlds: anthropology on new terrain (2002), junto com Faye Ginsburg e Brian Larkin, publicado em 2002 e ainda inédito no Brasil. Ele reúne 20 artigos sobre a comunicação de massa sob diversas perspectivas, produtos e países. Spitulnik é autora de um dos textos desta coletânea onde aborda sua pesquisa etnográfica sobre rádio na Zâmbia. Abu-Lughod também realizou uma pesquisa etnográfica sobre a recepção de televisão no Egito (2001) onde discute a interpretação dos personagens e das narrativas produzidas pela televisão norte-americana pelas mulheres nativas.

No Brasil, um dos trabalhos pioneiros sobre comunicação dentro do campo antropológico é a pesquisa sobre televisão da antropóloga Ondina Leal (1986). Em A leitura social da novela das oito, a autora estabelece um diálogo com os pensadores da Escola de Frankfurt e com os teóricos da comunicação, para entender o lugar e o papel da televisão, especialmente da novela das oito, na sociedade brasileira. Para isso, selecionou dois grupos de famílias para juntos assistirem à novela. $\mathrm{O}$ primeiro era formado por pessoas das classes populares e o outro por pessoas de camadas médias intelectualizadas. Ambos residentes na cidade de Porto Alegre. Ela percebeu que o significado simbólico da televisão era muito distinto nas duas famílias.

No âmbito da publicidade e do consumo, as pesquisas de Everardo Rocha $(1985,1995)$ foram uma novidade em termos de 
tema e abordagem. Na primeira, estudou os publicitários e analisou anúncios buscando entender a lógica da produção publicitária e seus significados. Em sua tese de doutorado procurou discutir as correntes que problematizaram os meios de comunicação de massa e investigar o lugar da publicidade na sociedade contemporânea.

Isabel Travancas desenvolveu em sua dissertação de mestrado uma pesquisa sobre carreira e identidade entre jornalistas (1993). Seu objetivo foi entender como se constitui a identidade deste profissional a partir de uma etnografia e de entrevistas com cerca de 50 jornalistas da imprensa carioca. Silvia Nogueira e Candice Vidal também escolheram o jornalismo e os jornalistas como objeto de investigação. A primeira realizando uma etnografia da redação de dois grandes jornais do Rio de Janeiro e a segunda fazendo uma análise da figura do repórter a partir das matérias do Prêmio Esso.

Esses são alguns trabalhos das décadas de 1980 e 1990 que podem ser considerados uns dos primeiros dentro dessa temática da antropologia da comunicação de massa no Brasil. De lá para cá, o campo cresceu e se ampliou. E um dos lugares para reflexão mais fecunda foram os congressos da área.

Em 2001, no XXV Encontro Anual da ANPOCS, realizado em Caxambu, Isabel Travancas coordenou com Patrícia Farias o Seminário Temático "Antropologia e comunicação”. Ele reuniu trabalhos sobre jornalismo, cinema, televisão, música e publicidade. Foi sem dúvida um dos primeiros congressos da área a ter um núcleo de discussão específico sobre meios de comunicação de massa. Uma parte destes artigos foi reunida no livro de mesmo título publicado em 2003.

Na 23a Reunião Brasileira de Antropologia (RBA), ocorrida em Gramado, Rio Grande do Sul, em junho de 2002, juntamente com Patrícia Farias, Isabel Travancas organizou uma mesa de Comunicações Coordenadas "Antropologia e comunicação" onde 
foram apresentados seis trabalhos sobre figuras públicas e o papel da mídia na sua construção, telenovelas, publicidade, imprensa e música. Foi uma tentativa de continuar levando o tema da comunicação de massa para os encontros da Associação Brasileira de Antropologia (ABA).

Em 2004, foi organizado pelos professores Peter Fry e Esther Hamburguer o Fórum de Pesquisa "Mercado, consumo e mídia: disputas por representações" na 24a RBA, realizada em Recife, Pernambuco, em junho. Neste encontro, o foco não foi apenas a questão da comunicação de massa, mas sua perspectiva de consumo e mercado. Dos 24 trabalhos apresentados, as principais temáticas foram: consumo, circulação de mercadorias, propaganda, moda, televisão e representações da mídia, em especial dos jornais.

No $25^{\circ}$ encontro da $A B A$, em 2006, não houve nenhum Grupo de Trabalho ou Seminário sobre comunicação de massa sob o olhar antropológico. Isso veio a acontecer na reunião de 2008, em Porto Seguro, Bahia, quando Isabel Travancas e Nara Magalhães coordenaram o Grupo de Trabalho "Diferenças e desigualdades na mídia: um olhar antropológico". Compuseram o GT 14 trabalhos e cinco painéis distribuídos em três sessões cujos temas foram: a representação da diferença na televisão, uma antropologia da mídia e imprensa, televisão, violência e consumo. A televisão foi, sem dúvida, o tema preponderante dos trabalhos e abordada de diversas formas. Estudos empíricos e teóricos, análises de programa e de receptores demonstrando que seu lugar vem crescendo também no contexto acadêmico e em particular no campo da antropologia.

Belém, no Pará, foi a cidade da $27^{a}$ Reunião Brasileira de Antropologia, realizada de 1 a 4 de agosto de 2010. Nesta reunião, Isabel Travancas com o antropólogo português e pesquisador do Instituto Universitário de Lisboa (ISCTE) Filipe Reis coordenaram o Grupo de Trabalho "Antropologia e meios de comunicação", 
cujo título foi inspirado no artigo de Debra Spitulnik (1993) "Anthropology and mass media". O grupo congregou 16 comunicações e cinco posters. Os autores dos trabalhos eram brasileiros, ainda que dois portugueses selecionados não tenham podido comparecer. A discussão e a temática da primeira mesa foram a metodologia de trabalho em pesquisas sobre comunicação. Já a segunda mesa versou sobre os trabalhos etnográficos sobre a imprensa no Brasil e em Portugal, e a produção e a recepção midiática em diferentes países foram discutidas na última sessão.

Além das reuniões da $\mathrm{ABA}$, aconteceram diversos eventos regionais destinados às regiões Norte e Nordeste denominados ABANNE. No ano de 2003, Patrícia Farias e Isabel Travancas coordenaram o Grupo de Trabalho denominado "Antropologia e comunicação" com 29 trabalhos distribuídos em seis sessões com os seguintes assuntos sendo discutidos: consumo e marketing, cinema e vídeo, música, televisão, mídia impressa e rádio e internet. Naquele momento, houve uma presença considerável de trabalhos sobre consumo, marketing e propaganda, uma vez que ainda eram raros os grupos dedicados a esses temas. A música também tem aparecido de forma cada vez mais eventual na medida em que há outros espaços de discussão para ela nos congressos. Os autores dos trabalhos não estavam restritos ao universo regional do Norte e Nordeste, havendo pesquisadores de todas as partes do país.

Na ABANNE realizada em Natal, Rio Grande do Norte, em agosto de 2009, Silvia Nogueira e Isabel Travancas foram as responsáveis pelo Grupo de Trabalho "Antropologia e comunicação" que consistiu em três mesas sobre: etnografias da comunicação, publicidade e direitos humanos e comunicação. $\mathrm{O}$ tema desta última estava estreitamente ligado à temática mais geral do encontro que foi “Direitos, Justiça e diferença na América Latina”. 
A última RBA, realizada na PUC de São Paulo em julho de 2012, contou com o Grupo de Trabalho "Antropologia da comunicação de massa” coordenado por Silvia Nogueira e Isabel Travancas. Neste grupo, foram apresentados 18 trabalhos de pesquisadores em distintos momentos da carreira, portanto, havia mestrandos, mestres, doutorandos e doutores, além de graduando escrevendo junto com mestres ou doutores os textos.

A diversidade regional foi outro ponto de destaque, não havendo apenas antropólogos da região Sudeste. Ao contrário, havia participantes de todas as regiões do país. Nem todos tinham formação em Antropologia. Gente de Letras e de Comunicação também fez parte do GT. As quatro mesas abordaram os seguintes temas: televisão, imprensa e mercado editorial, política e cinema e, a última, publicidade e consumo.

Como temos percebido, ao longo destes mais de 10 anos de participação em congressos, televisão continua sendo um tema muito relevante e segue despertando o interesse dos pesquisadores. Imprensa é outro assunto sempre presente nos grupos. Um tema que nem sempre é discutido dentro de uma perspectiva de uma Antropologia da Comunicação de Massa é o cinema, pois comumente faz parte do conjunto de pesquisas no campo da Antropologia Visual. A política sempre perpassa as discussões sobre os meios de comunicação, algumas vezes de forma mais genérica e outras, mais específica, como foi o caso deste grupo de 2012. Um assunto que raramente apareceu foi o mercado editorial e os livros de maneira geral. Algumas das exceções foram as pesquisas de Isabel Travancas. A primeira - sua tese de doutorado - foi apresentada no Seminário Temático da Associação Nacional de Pós-Graduação e Pesquisa em Ciências Sociais (ANPOCS) de 2001 com o título "O livro no jornal" e a segunda, a comunicação "O livro como objeto da mídia", compôs a programação do Grupo de Trabalho na Reunião de 
Antropologia do Mercosul (RAM) de 2011, sobre a qual falaremos em seguida.

Um detalhe importante nesta tentativa de mapear a presença da discussão sobre os meios de comunicação no campo da Antropologia corresponde às transformações sofridas pelos títulos dos GTs. Eles começam de forma mais aberta e depois passam a unir os dois campos - Antropologia e Comunicação -, até que, no último congresso, já se postulou uma Antropologia da Comunicação de Massa. Este título procura precisar o objetivo e o enfoque das pesquisas.

Além destes encontros nacionais bienais da $\mathrm{ABA}$ e dos encontros regionais, um congresso de Antropologia da América Latina vem crescendo a cada evento. Trata-se da Reunião de Antropologia do MERCOSUL - RAM - iniciada em 1995. Ela vem sendo realizada de dois em dois anos, na Argentina, no Brasil e no Uruguai.

Em julho de 2007, na VII Reunião de Antropologia do Mercosul sediada na Universidade Federal do Rio Grande do Sul (UFRGS), em Porto Alegre, os antropólogos Nara Magalhães e Sergio Caggiano - este último argentino e professor da Universidad de Buenos Aires e da Universidad de La Plata - organizaram o Grupo de Trabalho "Antropólogos e as interpretações de interpretações da mídia”. Foram discutidos os temas de gênero na mídia, do "Outro" e suas representações midiáticas e do consumo e da cultura popular e da cultura massiva em três sessões com apresentação de 18 dos 28 previstos. Por ser um evento internacional, havia pesquisadores de várias nacionalidades.

Na RAM seguinte, de 2009, na qual Buenos Aires foi a sede, quatro antropólogos - dois argentinos Maria Graciela Rodriguez e Sergio Cagginano e duas brasileiras, Isabel Travancas e Nara Magalhães - lançaram a proposta do Grupo "Antropología y comunicación”. Este GT recebeu mais de 70 resumos de autores de 
diversas nacionalidades. Foram selecionadas 37 comunicações, divididas em cinco sessões. A construção da representação de grupos diversos em diferentes mídias (imprensa, televisão, publicidade e rádio) foi um dos pontos mais abordados no conjunto dos trabalhos, assim como a internet apareceu como objeto de pesquisa através de estudos sobre lan houses e sobre as apropriações das classes populares desta nova mídia.

Na última RAM, realizada em Curitiba em 2011, Isabel Travancas e a antropóloga argentina Patrícia Fasano foram responsáveis pelo Grupo de Trabalho "Antropologia da comunicação". Seu objetivo foi reunir a maior gama possível de pesquisas antropológicas sobre a comunicação de massa produzidas nos países do MERCOSUL. Além de possibilitar uma discussão sobre os trabalhos, a intenção era refletir sobre os mesmos em uma perspectiva comparativa. Foram organizadas três sessões intituladas: "A construção da identidade na mídia: jovens e leitores, populações de fronteira e grupos indígenas", "A televisão em debate: identidade e consumo" e "Moda, gênero, saúde e política e suas representações midiáticas". Os 26 trabalhos que compuseram o grupo, entre seis painéis e 20 comunicações tiveram uma amplitude grande de temas. Mais uma vez, a televisão ocupou um lugar importante, seguida pela imprensa escrita. Pela primeira vez, o livro e seus leitores foram objeto de dois trabalhos.

Cabe dizer ainda que ao longo dos anos, desde que surgiram os primeiros GTs e similares sobre Antropologia e Comunicação, alguns dos autores presentes neste livro participaram de suas discussões de diferentes formas: como debatedores, apresentadores de comunicação oral e/ou ouvintes. Este é o caso particular de Ana Lucia Enne, Carla Barros e Silvia Nogueira, além de Isabel Travancas, que acompanharam mais de perto o desenvolvimento do campo. Nessa trajetória, ainda, foi possível perceber pessoas em 
diferentes níveis na hierarquia acadêmica se incorporando ao grupo: professores, doutorandos que viraram doutores e mestrandos que viraram mestres de um evento para outro. Assim, fazem parte desta coletânea pessoas que participaram mais de uma vez dos congressos citados, como Luciana de Oliveira, Jimena Massa e Lennita Ruggi, e pesquisadores que estão se aproximando da temática, como Julia Schnorr, Jeana Santos, Talita Castro, Janie Pacheco, César Cundari da Rocha Santos, Marcelo Francisco e Mercedes Calzado.

Este livro reúne 11 artigos apresentados no Grupo de Trabalho "Antropologia da comunicação de massa" da $28^{a}$ Reunião Brasileira de Antropologia, realizada na PUC de São Paulo de 2 a 5 de julho de 2012. Foram enviados para as organizadoras mais de 50 trabalhos e 18 selecionados para compor quatro mesas de temas variados. A primeira tratou da televisão, sua representação e recepção. A segunda foi sobre as narrativas da mídia e abordou o mercado editorial, a crônica e a imprensa em diferentes contextos. Política e cinema foram os temas centrais da terceira mesa e publicidade e consumo os da última.

Carla Barros vem estudando as empregadas domésticas desde seu doutorado em Administração na Coppead quando analisou o consumo de empregadas e sua relação com as patroas. No texto deste livro, ela segue investigando o mesmo grupo profissional e suas relações de consumo através do seriado A Diarista, da TV Globo, exibido entre 2004 e 2007. A seu ver, o cotidiano da diarista Marinete está muito marcado pela "carência material" e quando a protagonista tenta consumir o mesmo que os patrões é penalizada. Ao longo do programa, a protagonista se coloca como uma espécie de mediadora entre dois mundos: o dos "pobres" e o dos 
"ricos". Barros estabelece uma conexão entre o seriado e sua pesquisa etnográfica buscando entender as ambiguidades presentes nas representações de "patroa" e "empregada" e em seus comportamentos como consumidoras.

Ana Lucia Enne vem, desde seu mestrado e doutorado em Antropologia no Museu Nacional da UFRJ, pesquisando os meios de comunicação de massa, em particular a Baixada Fluminense, memória e representação social. Neste artigo, ela vai discutir um programa de televisão - a novela Vale Tudo - e o filme A rede social. A questão ética é o foco do seu trabalho. Partindo da recepção à novela quando de sua exibição pela primeira vez em 1988 e depois em 2011, Enne percebe uma diferença de reação do público em relação aos vilões e suas atitudes. Se, num primeiro momento, foram muito criticados, já no século XXI, suas atitudes e seu comportamento desonesto foram relativizados e de certa forma aceitos, como no caso do filme norte-americano sobre o processo de criação do Facebook e as atitudes do proprietário da rede social.

Julia Schnorr é mestranda em Comunicação Midiática da Universidade Federal de Santa Maria e seu artigo analisou dois grupos de jovens rurais de classes populares: um pertencente a famílias assentadas pelo Movimento dos Trabalhadores Rurais Sem Terra (MST) e o outro ligado ao projeto de Economia Solidária. Seu objetivo foi perceber como este universo se relaciona com o Jornal Nacional (JN) e suas representações do meio rural, do trabalhador do campo e da pobreza. Para eles, fica evidente que a prioridade do telejornal é o mundo urbano e apenas assuntos como o uso de agrotóxico e o agronegócio despertam maior interesse. Outros chamam a atenção para o fato de o MST aparecer sempre na televisão como um movimento violento, principalmente em suas manifestações. $E$ todos são muito críticos em relação à maneira como o $\mathrm{JN}$ apresenta a pobreza no meio rural, sempre a relacionando à miséria e à vulnerabilidade. 
A crônica e sua relação estreita com o universo urbano é o tema abordado por Jeana Santos. Para a pesquisadora doutora em Letras, a crônica é emblemática da experiência moderna e inaugura uma nova perspectiva para a cidade como um lugar de produção de novos sentidos e comportamentos. A partir de algumas crônicas da virada do século no Rio de Janeiro de Machado de Assis e João do Rio, Santos analisa a cidade que traduz o imaginário de uma época. A seu ver, João do Rio é uma figura paradigmática dessa junção entre o flâneur e o jornalista. Ele é aquele que com sua aguda observação irá documentar os tipos urbanos retratando, assim, a rua como essência da modernidade.

O universo de livros de autoajuda é o tema do trabalho de Talita Castro em sua tese de doutorado. Ela busca entender como este gênero de enorme sucesso comercial, no Brasil e no exterior, possui significados tão distintos em contextos diversos como o mundo acadêmico, o editorial e o público em geral. Sua reflexão parte da ideia de que estes livros são definidos pelos intelectuais como negativos, risíveis e pouco sérios. Castro analisou textos e entrevistas de autores de livros considerados de autoajuda e percebeu que os estereótipos neles presentes indicam que é através deles que se pensa esse gênero. A seu ver, a própria pesquisa antropológica sobre este tema acaba sendo vista com estranheza e desprezo. Do contrário, os únicos objetivos dessa investigação seriam: descobrir se os livros deste gênero são "eficazes" e tornam a pesquisadora capaz de escrever um deles e assim enriquecer.

A produção fílmica e as representações nela envolvidas referentes aos jovens e à juventude são temáticas compartilhadas pelos artigos de Janie Pacheco e de César Cundari da Rocha Santos, Lennita Oliveira Ruggi e Marcelo Francisco.

$\mathrm{O}$ texto de Janie K. Pacheco parte da premissa adotada por Dayrel (2003) de que existem jovens específicos, que se 
encontram em contextos específicos, o que significa que não há uma suposta juventude, mas juventudes. Para demonstrar e discutir esse modo de abordar o tema, a autora tece um breve panorama sobre produções fílmicas desde os anos 1950, embora seu foco de análise recaia sobre seis películas produzidas no período entre 2002 e 2011. Para Pacheco, uma vez que a juventude é uma categoria social consolidada e constituída por imagens midiáticas desde as primeiras décadas do século XX, é no cinema que se pode observar o modo como a cultura juvenil se expressa. Nesse sentido, embora as narrativas, na maioria das vezes, tenham como cenário os centros urbanos, as temáticas são diversas: violência e criminalidade, tráfico de drogas, busca por emprego, dificuldades no convívio social, iniciação sexual, relacionamento amoroso, entre outras.

César Santos, Lennita Ruggi e Marcelo Francisco optaram por abordar especificamente filmes sobre high school lançados nos anos 1980, em especial os do roteirista-produtor-diretor John Hughes, considerado nos EUA como pai do gênero. São analisados Gatinhas e Gatões (1984), Clube dos Cinco (1985), Mulher Nota Mil (1985), Curtindo a Vida Adoidado (1986), Garota de Rosa-Shocking (1986) e Alguém Muito Especial (1987). O que se pretende discutir são as formas de sociabilidade escolar presentes nesses filmes, envolvendo jovens entre si e nas relações com adultos. Para os autores, fica claro que, nas produções, a aprendizagem não é tida como relevante, perdendo espaço para temas recorrentes como consumo, popularidade e sexualidade.

Tanto Mercedes Calzado quanto Jimena Massa de algum modo trabalham com a ideia do medo, do risco e a questão de segurança em contextos argentinos distintos. No primeiro caso, relacionadas às imagens trabalhadas em campanhas políticas audiovisuais e, no segundo, a manchetes de jornais relativas à violência sexual. 
Em seu artigo, Calzado analisa as campanhas audiovisuais dos candidatos presidenciais na Argentina a partir do retorno da democracia, abordando os significados da violência e do risco em suas construções imagéticas. Como a autora observa, nas sociedades contemporâneas, a proteção se torna um imperativo categórico de gestão política, uma vez que o risco é percebido como incontrolável e fruto de uma debilidade estatal para lidar com ele. Assim, as campanhas eleitorais apresentam-se como locais onde simultaneamente é possível diagnosticar a construção de tais ameaças à ordem social e apresentar possibilidades de controle do "perigo" pelo Estado. A partir de promessas de campanha, a política surge, então, como um território de sonhos e esperanças.

Já Jimena Massa parte de um caso publicamente conhecido como "o estuprador serial de Córdoba" (Argentina), que teve enorme repercussão na mídia nacional e internacional. A autora mostra a construção social do medo, com ênfase nas retóricas midiáticas sobre a violência e a (in)segurança urbana. Discute, ainda, numa perspectiva de gênero, que a enunciação midiática constrói e amplifica um medo que é, quase sempre, feminino. Nessa narrativa, o estupro é tratado como um sofrimento repentino e como quebra do cotidiano, em que as mulheres são caracterizadas ao mesmo tempo como vítimas e corajosas, e o homem é representado a partir de imagens animalizadas ou patologizadas. A análise dessa construção discursiva permite mostrar também em que medida os imaginários midiáticos configuram práticas que modificam de forma substantiva hábitos e estilos de vida.

Quem também analisa um caso amplamente repercutido nos meios de comunicação de massa é Luciana de Oliveira. A autora apresenta e analisa os discursos sobre desenvolvimento e sustentabilidade presentes numa amostra do debate midiático nacional sobre a instalação da Usina Hidrelétrica de Belo Monte na Amazônia brasileira. Ao 
adotar a perspectiva teórica do "acontecimento" ou do "quase acontecimento", e da ideia de que os discursos "fazem-fazer" e "fazem-falar" - presente em Latour - a autora discute atores e enquadramentos tradutores de modos de entendimento acerca das relações entre natureza-cultura, que se colocam em disputas hegemônicas de sentido.

Finalmente, Silvia Nogueira, em seu artigo, tem como pressuposto o entendimento de que na nossa "sociedade do espetáculo" para entrar no jogo social da exposição midiática é fundamental tornar-se visível. Mais importante que a busca pela visibilidade em si é a administração de visibilidade na qual os jogadores tentam controlar o que e o modo como algo será dado a conhecer. Nesse sentido, a autora apresenta e analisa as estratégias utilizadas pela Secretaria de Comunicação da Presidência da República para a produção de informações sobre o "Brasil", direcionadas a formadores de opinião pública mundial, com o objetivo de influenciar as percepções sobre o país no âmbito internacional. Para isso, utiliza abordagens tanto do campo da Antropologia quanto das Relações Internacionais, numa tentativa de discussão sobre que "Brasil" é esse apresentado pelo governo brasileiro, e as dimensões políticas e culturais estratégicas presentes nesse jogo em que a utilização dos meios de comunicação de massa desempenha papel central.

\section{Referências}

ABU-LUGHOD, L. A interpretação de cultura(s) após a televisão. Cadernos de Antropologia e Imagem, Rio de Janeiro, n.132, p.103129, 2001. .; GINSBURG, F.; LARKIN, B. Media Worlds: anthropo-

logy on new terrains. Berkeley: University of California Press, 2002. 
ADORNO, T.; HORKHEIMER, M. Dialética do esclarecimento. Rio de Janeiro: Jorge Zahar, 1985.

BENJAMIN, W. Obras escolhidas. São Paulo: Brasiliense, 1998.

ECO, Umberto. Apocalípticos e integrados. São Paulo: Perspectiva, 1998.

LEAL, O. F. A leitura social da novela das oito. Petrópolis: Vozes, 1986.

NOGUEIRA, S. G. Facetas do rádio. Uma etnografia das emissoras de Ilhéus (Sul da Bahia). (Tese) Doutorado PPGAS/UFRJ, 2005. (mimeo).

. A construção da notícia em dois jornais cariocas: uma abordagem etnográfica. Dissertação (Mestrado em Antropologia Social), PPGAS/UFRJ, 1998. (mimeo)

PARK, R. A notícia como forma de conhecimento: um capítulo dentro da sociologia do conhecimento. In: BERGER, C.; MAROCCO, B. (Orgs.) A era glacial do jornalismo: teorias sociais da imprensa. Porto Alegre: Sulina, 2008. Vol. 2.

ROCHA, E. Magia e capitalismo. São Paulo: Brasiliense, 1990. . A sociedade do sonho. Rio de Janeiro: Mauad, 1995.

SPITULNIK, D. Anthropology and mass media. Annual Review of Anthropology, n. 22, p. 293-314, 1993. 
SOUZA, C. V. Repórteres e reportagens no jornalismo brasileiro. Rio de Janeiro: Fundação Getúlio Vargas, 2010.

TRAVANCAS, I. O mundo dos jornalistas. 4. ed. São Paulo: Summus Editorial, 1993.

TRAVANCAS, I.; FARIAS, P. (Orgs.). Antropologia e comunicação. Rio de Janeiro: Garamond, 2003. 


\section{Da mediação à punição: visões e confrontos do consumo entre classes em um seriado de TV}

Carla Barros

\section{Introdução}

O presente artigo se propõe a realizar uma análise das relações de consumo expressas no seriado A Diarista, exibido pela TV Globo entre os anos de 2004 e 2007. Para tanto, será desenvolvida uma análise das representações relativas aos diferentes universos sociais que aparecem no seriado - a saber, o dos "pobres" e o dos "ricos" - onde a dimensão do consumo surge como meio privilegiado de expressão de diferenças sociais. Douglas e Isherwood (2004), em um trabalho clássico no campo dos estudos do consumo, chamavam atenção para a capacidade deste fenômeno de "dar sentido" ao universo cotidiano: "O consumo usa os bens para tornar firme e visível um conjunto particular de julgamentos nos processos fluidos de classificar pessoas e eventos" (p.115). O campo de estudos de consumo veio se constituindo a partir daí com a contribuição de diversos autores - entre os quais, Colin Campbell (2001) e Daniel 
Miller (2010) - que procuraram retirar este fenômeno da posição de mero reflexo da produção, colocando-o em um lugar central de análise, capaz de produzir um discurso sobre as relações sociais. Abandonava-se, assim, uma visão utilitária do consumo, que prevalecia no viés economicista, passando a se dar a devida atenção ao seu significado cultural, suas práticas e seus sentidos públicos, em contraposição às explicações centradas no plano do indivíduo.

$\mathrm{O}$ artigo se insere, assim, em uma perspectiva de diálogo entre as áreas de antropologia do consumo e comunicação, procurando, ainda, relacionar a produção televisiva escolhida ao seu contexto sociocultural mais amplo, promovendo um contraponto entre a obra ficcional e o material resultante de uma etnografia realizada pela autora, voltada para a compreensão do consumo de empregadas domésticas (BARROS, 2007). Neste estudo, a mídia televisiva apareceu como peça importante no encontro entre dois mundos o da patroa e o da empregada.

Conforme já argumentou Gomes (1998), a telenovela pode, até certo ponto, ser analisada como um mito, por apresentar uma visão "totalizante" da realidade:

O que significa dizer, mais uma vez, que na telenovela brasileira não existe problema impossível de ser 'formulado' e equacionado, uma vez que ela apresenta um modelo completo e holístico de sociedade, no qual tudo se encontra encaixado (hierarquizado) e tem o seu lugar (GOMES, 1998, p.25).

A autora propõe, na verdade, que a novela seja percebida como um produto que se situaria entre o discurso mítico e o histórico, por ter uma ambição totalitária por um lado, e, por outro, incorporar o tempo e a mudança. 
Partindo da ideia de que o seriado $A$ diarista também possa ser analisado em seus aspectos míticos, no sentido de podermos encontrar ali um modelo holístico e "estável" de sociedade, onde as partes se encaixam de modo hierárquico (DUMONT, 1972), o desafio da análise recai, inicialmente, sobre o reconhecimento das representações sobre os universos sociais que se confrontam na trama e os modos possíveis de reconhecimento e relacionamento com o mundo do Outro.

Antes de entrar na análise propriamente dita, cabe aqui indicar o que está se entendendo como "modo hierárquico". Louis Dumont (1972) argumenta que a noção de indivíduo é o princípio estruturador da ideologia moderna, em que as partes (indivíduos) prevalecem sobre o todo (sociedade). Na sociedade moderna, o indivíduo é concebido como o valor supremo, definido como um ser autônomo, livre das amarras sociais. A este modelo Dumont contrapõe a noção de hierarquia, em que o todo tem sempre precedência sobre as partes. Aqui, a identidade das pessoas se constitui a partir de uma série de relações pré-definidas pela totalidade social, em que um termo da relação tem primazia sobre o outro - homem sobre mulher, velhos sobre novos, e assim por diante. No esquema hierárquico, a determinação de valores está fundamentalmente em esferas localizadas fora do indivíduo, como a religião, a família, a comunidade e a tradição. A hierarquia estudada por Dumont aparece em sua obra não apenas como uma propriedade do sistema de castas da Índia, mas como um princípio de classificação presente em qualquer sociedade. Hierarquia, nesta concepção, implica em complementaridade entre as partes, ou seja, em relações não-igualitárias onde as diferenças se encontram naturalizadas.

A seguir, segue a análise proposta das representações sobre universos distintos no seriado A Diarista - a contraposição do mundo de "pobres" e "ricos". 


\section{A diarista: consumo e punição no confronto entre dois mundos}

O seriado A Diarista, exibido pela TV Globo de abril de 2004 a julho de 2007, ao longo de quatro temporadas ${ }^{1}$, figura ao lado de outras produções que passaram a apresentar histórias desenvolvidas em ambientes de classes populares, como Cidade dos Homens, seriado da mesma TV Globo exibido entre os anos de 2002 e 2005, e Vidas Opostas, novela veiculada na TV Record em 2006 e 2007, ambas com enredos que se passam no cotidiano de favelas cariocas. No seriado A Diarista, as tramas têm como cenário principal o emprego doméstico e envolvem Marinete, a diarista-personagem título. Chama atenção, inicialmente, que em um seriado com uma protagonista pertencente às camadas populares, a dimensão do trabalho seja central para o desencadeamento das tramas - as histórias são desenvolvidas, em geral, a partir de situações que ocorrem no "serviço" de Marinete, em especial da interação entre a diarista e seus patrões, que mudam a cada episódio. $\mathrm{O}$ universo popular por onde Marinete circula também tem destaque nas histórias, sendo formado pelas amigas Dalila (vizinha e "mãe de santo"), Ipanema (trabalha como bombeira e se veste de modo masculinizado) e Solineuza (melhor amiga, sujeita a chacotas da parte de Marinete devido à sua enorme "burrice"). $\mathrm{O}$ dono da agência de empregadas, seu Figueirinha, completa a lista dos personagens fixos do seriado.

Ao fazer um breve comentário sobre o seriado em um trabalho anterior (BARROS, 2007), já havia ressaltado que uma das marcas do programa era a recorrente afirmação da diferença entre "pobres"

1 Em 2011, estava previsto o retorno do seriado à grade da emissora; no entanto, as gravações foram interrompidas, conforme divulgado na época pela imprensa, devido a problemas de saúde da atriz Claudia Rodrigues, protagonista do programa. 
e "ricos" - uma série de bordões eram ditos pela protagonista durante os episódios, destacando as características e a imutabilidade de cada uma daquelas condições sociais, em especial a da pobreza, entre eles: "pobre sempre anda com a carteira profissional na bolsa", "ouvido de pobre não escolhe o que ouve", "fruto do mar de pobre é banana d'água“, "pobre só vai pra frente quando a polícia corre atrás", "em tempos de saci, uma calça dá pra dois" e "bêbada rica é divertida, bêbada pobre é pervertida". Concluindo o comentário, observava que todas as vezes que a diarista vivia alguma situação de possibilidade de mudança do seu lugar social, os resultados eram catastróficos, levando a um retorno e à conformidade com o papel de subordinada ao final.

Em uma passagem emblemática de uma edição do programa ${ }^{2}$, Marinete chora copiosamente ao ver uma propaganda de margarina, dizendo que aquela cena nunca iria acontecer com ela - na peça publicitária, um homem oferece à sua mulher uma fatia de pão com margarina, em um clima de felicidade extrema, tendo como cenário uma cozinha de classe alta, ampla e bastante iluminada pela luz do sol. O "sonhar acordado" provocado pela propaganda (ROCHA, 1985; CAMPBELL, 2001) está interditado para a diarista, que não poderá viver a transformação promovida pelo produto, porque o seu lugar - como "pobre" - não será mudado, por mais que tente.

Seu papel nas tramas é, muitas vezes, o de salvar os "ricos" de alguma situação crítica, embora em tantas outras ela provoque um grande caos nas casas onde trabalha. Nos moldes de uma relação hierárquica (DUMONT, 1972), os papéis são definidos de modo complementar - cabe à diarista "pobre" cuidar e, eventualmente, "salvar" seus patrões, enquanto recebe em troca o pagamento em forma de "diária" e proteção.

2 Programa exibido no dia 19 de abril de 2005. 
Em um artigo elaborado com outros colegas ${ }^{3}$ (SUAREZ; MOTTA; BARROS, 2009), destacamos como a oposição de classes sociais ocupa um papel central na definição dos personagens e suas trajetórias no seriado. Esta oposição ("pobres" x "ricos") é traduzida no comportamento de consumo de Marinete e de seus patrões. Assim, o universo do consumo dos ricos é marcado pelo excesso, esbanjamento e fartura; o de Marinete e suas amigas, pelo signo da restrição e escassez. Em um dos episódios ${ }^{4}$, por exemplo, Marinete controla em sua casa o consumo de suco por Dalila, enquanto na casa dos patrões, ela reclama da quantidade de comida que precisa preparar: "parece que eles nasceram numa lanchonete!" O episódio também mostra o desperdício, já que os adolescentes jogam no lixo parte dos sanduíches preparados.

Para ilustrar a contraposição entre os dois universos, reproduzo aqui uma das análises ${ }^{5}$ :

A oposição restrição (pobre) x excesso (ricos) também se evidencia quando Marinete idealiza a viagem que terá oportunidade de fazer ao exterior. Figueirinha, o dono da agência de empregos, pretende lhe remunerar com a passagem de ônibus. Sem outra opção de receber seu pagamento, ela aceita a proposta já que também se sente tentada pela possibilidade de viajar para fora do país. Em pensamento a diarista "viaja” para um paraíso imaginário, onde ela está deitada numa cadeira

3 As análises dos episódios apresentadas no artigo feito com colegas foram desenvolvidas por Maribel Suarez para um trabalho realizado no âmbito de uma disciplina ministrada pelo Prof. Paulo César Motta, no curso de Doutorado em Administração do IAG/PUC-Rio.

4 Episódio: Aquele com os Adolescentes.

5 Episódio: Aquele do Paraguai I. 
de praia, com chapéu, maiô e óculos escuros. A música de fundo é "Viva la vida loca", e um homem parecido com o cantor latino Rick Martin dança, enquanto ela bebe um drink de abacaxi e come frutas, com voracidade. A seguir, conversando com as amigas, esse "sonho de consumo" volta a se manifestar. No que poderia ser o quarto de um luxuoso motel, Marinete assiste à dança do belo "latino" e bebe champanhe com ansiedade: primeiro normalmente, depois do gargalo da garrafa, deixando transbordar pela boca, até que ela come a própria taça. Enquanto ele rebola, ela também se delicia com gelatina, lambuzando o corpo, no que promete ser uma noite de excessos. Numa cena a seguir, Solineuza comenta com Dalila: "Tu já imaginou a Nete no estrangeiro, dando uma de patrão e fazendo compras?” Assim, o processo de transformação de Marinete (do comportamento de empregada à patroa), concretizado na viagem ao exterior, parece reforçar a visão dos patrões como uma vida de esbanjamento, em contraposição às limitações que a doméstica vive no seu dia-a-dia. (SUAREZ; MOTTA; BARROS, 2009, p.214).

Neste e em outros episódios analisados no referido trabalho, alguns aspectos chamam atenção. Em especial, o lugar das práticas de consumo como definidoras de diferentes situações de classe e a dramatização da "mudança de lugar" da diarista, quando confrontada com a possibilidade de usufruir do "mundo dos ricos", seja como sonho ou "realidade". O seriado sugere que mesmo tendo a posse dos bens de outra classe, Marinete termina por revelar o seu lugar de origem. Ainda que consiga vencer a "barreira de entrada" para o consumo (por exemplo, adquirir o produto), a forma de consumir acaba por revelar que ela não pertence ao universo dos ricos. Trata-se do que Bordieu (1980) classificou como habitus e 
se relaciona ao fato de que uma pessoa pertencente a determinado grupo compartilhe gestos, posturas, que têm no conjunto um poder modelador que acaba garantindo a homogeneização dos gostos dentro de um grupo social.

Outro ponto a ser destacado em $A$ diarista é que a experimentação do consumo dos ricos não se dá a partir de uma escolha de Marinete, mas sim como fruto de acaso, revelando seu pouco controle das situações em que se observaria um deslocamento do personagem para uma experiência de outra classe social. Pensando de um modo relacional, o "consumo dos ricos" seria marcado pela escolha e excessos, enquanto o "consumo dos pobres" pela passividade e carência material. Ao tentar passar do seu universo social para o do outro através da mediação do consumo, a diarista experimenta uma série de infortúnios e humilhações, que a levam invariavelmente de volta ao seu mundo familiar.

Pode-se fazer aqui um contraponto com o trabalho de Machado e Vélez (2008 p.96) sobre a telenovela colombiana Yo Soy Betty la $\mathrm{Fea}$, onde os autores mostram que o conflito básico apresentado na obra é instaurado entre "beleza" e "feiúra", sendo este último "um conceito que tem menos a ver com atributos físicos do que com a estratificação dos papéis sociais numa sociedade de valores rigidamente cristalizados". Ao analisar a originalidade do modelo trazido por essa novela, chamam atenção de como os aspectos físicos - e, portanto, visíveis dos personagens - são percebidos como correlacionados com o lugar ocupado dentro de um determinado universo social concebido, em um primeiro momento, como imutável. A novela acabaria, na verdade, por subverter e "desarrumar" esse sistema estável apresentado inicialmente, enquanto no seriado brasileiro se observa uma reafirmação da estrutura hierárquica que sustenta as relações entre pobres e ricos. 


\section{Luz, Câmera... Inanição!: a lógica da carência material}

Será desenvolvida agora uma análise do episódio $L u z$, Câmera... Inanição!, da $3^{a}$ temporada, escolhido por ser um caso exemplar da lógica da carência material atribuída ao universo da diarista, além de apresentar um "filme dentro do filme", o que acaba por explicitar as representações sobre o mundo dos "pobres" que se quer aqui evidenciar.

O episódio começa com uma contraposição clássica no seriado - enquanto Marinete trabalha e "dá duro" fazendo faxina, a patroa dorme no sofá, como um sinal claro do ócio reinante na casa dos ricos. Nesse momento, toca o telefone e a patroa é acordada por Marinete para atender seu filho. Desde o início, as referências e a caracterização do personagem do filho da patroa aparecem com contornos irônicos, começando pelo discurso da mãe, que reclama que, aos quarenta anos, ele "vive pedindo dinheiro para fazer filmes com mendigos, ele diz que é artista, cineasta”. Em seguida, a patroa pergunta se Marinete não conhece alguma simpatia que pudesse tirar a "mania" de cineasta do filho. A delimitação dos universos da diarista e da patroa é recorrente no seriado, onde a religiosidade popular, o misticismo e as "crendices" são associados ao cotidiano de Marinete, em contraposição ao universo da ciência e racionalidade presentes no mundo dos ricos.

Por outro lado, os patrões podem recorrer, eventualmente, ao universo "mágico" popular, como é o caso, sugerindo a existência de certa eficácia nesses recursos, além do aspecto de complementaridade e "ajuda mútua" entre dominantes e dominados. Ao final da conversa, Marinete sugere à patroa fazer uma promessa para a padroeira de Porto das Caixas, relatando ter tido sucesso em um pedido para ter um "fogão de seis bocas", motivo de orgulho. 
Combinam, então, que a diarista irá, no dia seguinte, fazer uma faxina em um outro apartamento da patroa onde mora o filho.

A caracterização do universo social da diarista e de suas amigas prossegue com o emblema da restrição material - em uma cena na cozinha de sua casa, Marinete frita um ovo com três gemas, para ser dividido entre ela, Solineuza e Ipanema. Os pedidos quanto ao cozimento do alimento são feitos à Marinete - Solineuza quer a "clara mole", enquanto Ipanema quer "dura" - mas não podem ser atendidos, por ser, de fato, um só ovo "fundido", a ser repartido pelas três. Uma indicação, entre outras, que sugere um cotidiano onde as escolhas e gostos pessoais são suplantados pela lógica da escassez.

Vale ressaltar que o episódio promove, em um determinado plano, uma inversão no habitual contraponto entre ricos e pobres. O cineasta aparece inserido em um cenário de restrição material sua geladeira está vazia, sua casa tem poucos bens materiais e ele não paga a pensão dos filhos. Só que esta restrição não é fruto do "destino" de ter nascido pobre, mas sim resultado de sua escolha em ser cineasta; uma opção que, mesmo ridicularizada na trama, revela um "sonho" a ser perseguido, como uma expressão de sua idiossincrasia e vontade individual. Ao mesmo tempo, é como se o personagem "se desse ao luxo" de viver como pobre, pois sabe que a qualquer momento pode recorrer à mãe para sair da circunstancial carência material. Embora haja esse plano de inversão no episódio, as usuais representações sobre o universo da diarista se reproduzem em outros momentos, como a adesão ao mundo místico-popular e a comida compartilhada.

O episódio prossegue no apartamento onde mora o cineasta, Serginho, que aparece em uma primeira cena fazendo planos com a sua assistente e namorada, Dani. A chegada de Marinete apresenta-se como uma solução para o cineasta, que até então não sabia objetivamente sobre o que seria seu próximo filme, tendo definido 
apenas que falaria de "pobre". Resolve, então, que Marinete será a protagonista, por encarnar a realidade de uma pessoa marcada pelo signo da penúria. Entusiasmado, começa a imaginar o filme, descrevendo para a namorada como seria a primeira cena: "A história começa numa boca arreganhada, sem dente. Aí passa para o dia-adia da Marinete, vamos buscar a origem da pobreza na infância, já que na infância ela não teve o que comer. O homem é o que come”.

Nesse meio tempo, uma série de incidentes faz com que o dinheiro que Marinete e as amigas usariam para ir até Porto das Caixas para pagar a promessa relativa ao fogão de seis bocas cai nas mãos do cineasta, livrando-o de ser preso por não ter pagado a pensão dos filhos. $\mathrm{O}$ cineasta resolve contar à Marinete que ela será a protagonista do filme, tentando convencê-la de que o dinheiro está sendo aplicado em uma boa causa, já que agora ela e Ipanema são "produtoras associadas" do filme, e terão seus dividendos com o sucesso futuro. Apesar da relutância inicial, Marinete, por fim, concorda com a realização das filmagens.

A decepção do cineasta e da assistente é grande ao constatarem que o ambiente da casa de Marinete não é de penúria como pensado ao ir ao banheiro, ficam desalentados ao constatarem que "a descarga funciona e "o papel higiênico não está pendurado no arame”. O desencanto prossegue ao verem que o fogão da diarista tem seis bocas e que a geladeira é maior que a do cineasta, além de estar repleta de comida. Serginho reclama que o apartamento foge totalmente da ambientação pensada - que incluiria "cachorro amarrado com fio de luz, sandália remendada com grampeador, caneca feita de lata e móveis quebrados". A partir daí, tem a ideia de filmar em seu próprio apartamento, mais condizente com a precariedade que esperava encontrar.

As distâncias entre os universos sociais voltam a ser enfatizadas na sequência do episódio. Para fazer um "laboratório", o cineasta e a assistente vão a um forró, para "sentirem de perto" a diversão 
popular. Um "nativo" chama a namorada para dançar, e Serginho a incentiva: "Aproveita pra saber como é que eles são..."

Nesse ínterim, as coisas começam a dar errado para Marinete e as amigas, o que é interpretado como sendo como um sinal do não pagamento da promessa - o emblemático fogão de seis bocas começa a apresentar defeito, Solineuza é abandonada pelo namorado e o cabelo de Ipanema começa a cair em grande quantidade.

O filme começa a ser rodado no apartamento do cineasta, em preto e branco, e com a voz em off anunciando que a obra iria falar de "Marinete dos Santos, uma vítima do sistema. Uma mulher batalhadora que começou de baixo, e lá ficou”.

Após um incêndio em seu apartamento durante as filmagens, o cineasta fica sem ter onde morar. Marinete sugere que volte para casa da mãe, indo com ele para fazer a mediação. A mãe o aceita em casa, com a condição de que "pare de brincar de artista e arrume um emprego sério". O retorno do cineasta acontece após a mãe ter feito uma promessa "à santinha", pedindo que o filho largasse a ideia de ser cineasta, conforme sugerido por Marinete. Ao ver seu pedido atendido, agradece à Marinete, indo todas, ao final do episódio, até Porto das Caixas para pagar a promessa. Na cena dentro da igreja, a distância entre a atitude das personagens fica bem marcada. A postura da patroa é de silêncio respeitoso, lançando olhares de reprovação para a falta de contenção das outras. Além das roupas exuberantes e decotadas, o núcleo da diarista fala alto e mostra um relacionamento bem próximo com a santa, deixando que todos ouçam suas rezas. Marinete agradece as graças alcançadas utilizando uma linguagem cheia de gírias, conversando com a santa com grande intimidade.

Após o cumprimento da promessa, tudo retorna ao normal - o fogão volta a funcionar sem problemas, o cabelo de Ipanema deixa de cair e o namorado de Solineuza reaparece. 
O episódio Luz, Câmera... Inanição! é de especial interesse porque, por um lado, ao ironizar a percepção do cineasta sobre o universo de Marinete, acaba relativizando a própria visão dominante em outros episódios, onde o universo dos pobres é, de modo recorrente, equacionado à escassez e o dos ricos à opulência.

Tanto na visão do cineasta sobre o que seria a "pobreza", quanto na percepção dominante nos episódios sobre o mundo dos pobres, encontra-se atualizado um determinado modo de conceber o universo de "baixa renda". Existe aqui a ideia de que grupos populares viveriam em um mundo marcado pela lógica da falta, da sobrevivência e da carência material. Os recursos, sempre escassos, levariam a uma postura de passividade frente à vida e de sujeição a condições sociais adversas. Analisando especificamente os reflexos desta visão no campo do consumo, membros de camadas populares não seriam protagonistas porque não fariam escolhas - como já indicou Slater (2002), a possibilidade de escolha é fundamental na gênese do consumo moderno - mas responderiam a "necessidades básicas". Tais percepções encontram-se, de fato, bastante disseminadas na sociedade, tanto no campo do senso comum quanto em certos segmentos do meio acadêmico. Por um lado, pode-se perceber uma visão moralista sobre o consumo, que "condena" os pobres quando estes adquirem bens "supérfluos" do ponto de vista de quem acusa. Nessa concepção, os indivíduos de baixa renda deveriam se restringir ao mundo dos bens adequados ao seu status, marcado pela carência material e sem escolhas no campo do consumo. Um dos modelos produzidos pelo mundo acadêmico e que tem correspondência com tais pressupostos é o da "hierarquia de necessidades", criado nos anos 40 pelo psicólogo e Professor universitário norte-americano Abraham Maslow.

A "pirâmide de Maslow" propõe que o comportamento humano possa ser explicado a partir do entendimento de uma 
hierarquia de necessidades universais, que compreenderia cinco categorias distintas, das mais "básicas" às mais complexas: necessidades fisiológicas, de segurança, de participação e afeição, de estima e de autorrealização. Estas necessidades estariam organizadas de forma hierárquica, pois se manifestariam no ser humano à medida que um estágio anterior fosse satisfeito (MASLOW, 1954). Existiram "necessidades mais básicas", que estariam na base da pirâmide, tais como fome, sede, sono e sexo - os indivíduos nesse plano seguiriam seus instintos, consumindo para saciar suas necessidades de sobrevivência e não teriam novas motivações até que esse estágio fosse satisfeito.

Modelos como o da "Pirâmide de Maslow", que atualizam a lógica da carência material, podem ser refutados quando se considera que precariedade de recursos materiais não significa precariedade simbólica. $\mathrm{O}$ ser humano se caracteriza enquanto tal por estar imerso na cultura, que não pode ser entendida como um simples agregado de traços culturais. Sua característica distintiva é exatamente o fato de viver segundo uma lógica simbólica, e não prática, como mostrou Sahlins (1979), entre outros. O fato de que alguns grupos tenham mais dificuldades de sobrevivência material não implica que sejam movidos segundo uma lógica prática, de sobrevivência, o que, se fosse verdade, inclusive, faria deles menos humanos do que os outros.

Pensando no campo das ciências sociais brasileiras sobre os modos de vida da classe trabalhadora, vale ressaltar que até os anos 80, a maioria desses estudos - inventariados de forma abrangente por Sarti (1996) - definia tais segmentos essencialmente a partir de suas relações de trabalho. Tanto em abordagens marxistas quanto nos trabalhos que pesquisavam as "estratégias de sobrevivência" da base da pirâmide, o foco de análise recaía sobre os mecanismos que as famílias estudadas usavam para garantir sua "sobrevivência 
material". Como destacou Sarti (1996, p.17), a dimensão simbólica não encontrava espaço nesse tipo de análise, pois tudo parecia ser movido graças a uma "razão prática" que permitia às pessoas sobreviverem em um ambiente de grande escassez material. Tratava-se de uma verdadeira lógica da "falta", seja de bens, de trabalho ou de "consciência de classe". Somente a partir dos anos 80 , o quadro se reverte, em especial, com o surgimento de vários estudos etnográficos abordando temas como o cotidiano e relações de família e gênero. Estes estudos passaram, assim, a enfatizar o modo de vida e as representações sociais de segmentos de trabalhadores pobres urbanos, mostrando como é a dimensão cultural que, de fato, instaura a vida em sociedade. $\mathrm{O}$ foco na "falta" acaba por encobrir o simbolismo que organiza e cria sentido para a vida de qualquer grupo social (SAHLINS, 1979).

\section{Televisão, consumo e mediação}

Procurando analisar de que modo são representados diferentes universos sociais e suas relações em $A$ Diarista e sabendo que o "outro" pobre é uma construção do seriado, e não um dado natural, alguns aspectos merecem atenção. Em primeiro lugar, o modo como a dimensão do consumo aparece como meio privilegiado na definição do que seja o universo de pobres e ricos. O "mundo dos bens" (DOUGLAS; ISHERWOOD, 2004) comunica estilos de vida e embute visões de mundo, classificando pessoas e coisas como em um grande sistema totêmico (SAHLINS, 1978; ROCHA, 1985). Como visto, o seriado aborda o relacionamento da diarista com seus patrões a partir de um "viés de classe", apresentando uma contraposição entre dois universos distintos - um marcado pela escassez e outro pela abundância material. A estabilidade dos dois mundos é rompida quando a diarista tenta usufruir de bens 
e serviços do mundo do "outro" rico. Quando isso acontece, uma série de problemas e catástrofes se sucedem, até que a personagem volte para seu local de origem, sugerindo que a mudança de lugar, nesse contexto, apresenta-se como um caminho a ser evitado a todo custo. As diferenças entre pobres e ricos encontram-se naturalizadas e expressas no mundo dos objetos, e o consumo torna-se, assim, o palco das diferenças.

Retornando à questão dos aspectos míticos da narrativa do seriado, foi visto como as relações hierárquicas que estruturam o sistema são reafirmadas ao final. O mito, segundo Lévi-Strauss (1970), traz sempre uma espécie de "conforto" social ao promover uma resolução de ambiguidades colocadas inicialmente. Paradoxos são assimilados e resolvidos por fim, já que o mito contém uma mensagem em prol da tradição. $\mathrm{O}$ seriado, como visto, reafirma os lugares de patroa e empregada como universos distintos e complementares, sendo a mudança de lugar encarada como uma disrupção no sistema, que deve logo ser reparada para o retorno à estabilidade inicial. Como o mito tem esse efeito estabilizador, acaba por explicitar o custo da mudança e reforçar um universo marcado por relações hierárquicas.

A possibilidade de se tornar o Outro, no caso, a trajetória do universo da diarista ao da patroa através do consumo, revela um dos pontos críticos da sociedade brasileira. Conforme já sugeriu DaMatta (1994), encontramos em larga escala em nosso contexto um "horror à mobilidade", especialmente no que tange à troca efetiva de posição social. A anulação das diferenças e a possibilidade de mudar de lugar teriam espaço legitimado no carnaval, uma experiência que promove a inversão das relações cotidianas, mas com hora certa para começar e terminar. Em outros momentos, a ideia de mobilidade social seria um ponto crítico e sensível de nossa estrutura social. 
O episódio analisado chama atenção porque, ao ironizar a percepção do cineasta sobre o universo de Marinete, acaba relativizando a própria visão dominante em outros episódios, onde a representação dicotômica sobre universo dos ricos e dos pobres prevalece. De certo modo, a trama do cineasta é um momento em que o seriado ri de si próprio. Embora a contraposição entre escassez e opulência esteja presente como em outros episódios, o cineasta aparece como "esfomeado" e "pobre", enquanto Marinete tem a casa arrumada e a geladeira cheia. $\mathrm{O}$ episódio opera, de fato, um ir-e-vir nos signos dos dois universos, que parecem estar sempre revestidos de um certo grau de ambiguidade. A compra do "fogão de seis bocas", símbolo do mundo dos ricos, não foi fruto do esforço e do trabalho de Marinete, mas sim ganho em uma rifa, após o pedido feito através de uma promessa.

O seriado expressa, dentro do que foi visto, algumas questões importantes na dinâmica da sociedade brasileira, no que se refere à possibilidade da mudança, localização de pessoas dentro do tecido social e as relações possíveis entre diferentes segmentos sociais. Mais uma vez, o episódio do cineasta é exemplar por mostrar o papel de mediadora exercido pela diarista - que é quem, afinal, apresenta a solução para o problema da patroa. A "promessa para a santa" sugerida por Marinete acaba funcionando, fazendo com que o filho deixe de ser artista e volte a morar na casa da mãe.

Na sociedade moderno-contemporânea, o tema da mediação tem grande relevância, por permitir o trânsito e o contato entre universos distintos em um cenário de heterogeneidade sociocultural e diversificação de papéis sociais. Os indivíduos imersos no meio urbano, em especial, estão potencialmente expostos a uma grande diversidade de experiências, por circularem através de universos onde se atualizam valores e visões de mundo distintas e, às vezes, conflitantes, como assinalam Velho e Kuschnir (2001): 
A vida social só existe através das diferenças. São elas que, a partir da interação como processo universal, produzem e possibilitam as trocas, a comunicação e o intercâmbio. $\mathrm{O}$ estudo da mediação e, especificamente, dos mediadores permite constatar como se dão as interações entre categorias sociais e níveis culturais distintos. [...] Num contínuo processo de negociação da realidade, escolhas são feitas, tendo como referências sistemas simbólicos, crenças e valores, em torno de interesses e objetivos materiais dos mais variados tipos. A mediação é uma ação social permanente, nem sempre óbvia, que está presente nos mais variados níveis e processos interativos. (VELHO; KUSCHNIR, 2001, p. 9-10).

O sistema social brasileiro, em particular, ainda mantém em vários planos uma estrutura hierárquica com muitas gradações e um padrão de dominação de cunho personalista, como já mostrou a análise clássica de DaMatta (1981). Não se está aqui desconsiderando a dinâmica histórica do país, em que as relações sociais marcadas pelo individualismo e pelos princípios universais estão cada vez mais presentes, mas apenas afirmando que uma visão de mundo hierárquica (no sentido de Dumont, 1972), ainda, é bastante presente em diversos planos sociais. Nesse contexto, mediadores são figuras fundamentais, por facilitarem a comunicação entre as diversas partes do sistema.

Em um estudo anterior (BARROS, 2007), analisei o papel da empregada doméstica como uma importante mediadora na sociedade brasileira. No trabalho em casa de famílias de camadas médias e altas da população, as empregadas têm contato com códigos culturais distintos de seu meio de origem, o que fornece a possibilidade de investigação da dinâmica desse encontro em que regras, 
hábitos, gostos, estéticas e comportamentos são comunicados e confrontados. A vivência cotidiana com a "intimidade" de uma realidade distinta da sua faz dela uma intérprete privilegiada, que leva e comunica diferentes experiências sociais de um ponto a outro de sua trajetória, tornando-se, assim, uma mediadora entre estilos de vida e experiências sociais diversas.

O seriado se insere nesse contexto cultural, mostrando uma relação de complementaridade entre patroa e diarista - a primeira oferece salário e eventual proteção, a segunda, além do seu trabalho que contribui para a reprodução social dos ricos, pode servir de ponte para que estes tenham acesso ao universo mágico-religioso popular, que é onde as coisas realmente se resolveriam.

Hamburger (2005) lembra que segmentos sociais de classes populares consomem o conteúdo televisivo, em especial, as novelas, como modo de "se instruir sobre formas legítimas e chiques de comportamento, que identificam como verossímeis em situações distantes no espaço geográfico e/ou social” (HAMBURGER, 2005, p.169). A autora, em outro trabalho (HAMBURGER, 1998) já havia sugerido a ideia de "repertório compartilhado" na experiência televisiva, como um modo privilegiado de diálogo, troca de informações, julgamentos morais e aprendizagem entre telespectadores de diferentes classes sociais. Almeida (2003), por sua vez, mostrou em um estudo como é possível que, através da novela, determinados segmentos sociais tomem conhecimento dos modos de vida de outros grupos, que não teriam acesso de outra forma, promovendo uma espécie de "abertura" para o consumo. $\mathrm{O}$ trabalho mencionado (BARROS, 2007) segue esta linha de análise, mostrando a importância dos programas de televisão no cotidiano das empregadas, por permitirem uma imersão na sociedade de consumo e um "aprendizado" dos códigos e objetos característicos desta sociedade, em especial, do mundo dos ricos - como eles são e 
o que eles consomem. Assim, a empregada, ao circular por diferentes universos sociais, observa as "novidades" na casa da patroa que podem ser vistas também nos conteúdos televisivos - a mídia, nesse sentido, reforça um imaginário referente ao estilo de vida e hábitos de consumo dos mais abastados. "Aprende-se" em primeiro lugar a perceber como os bens são adequados para expressar distinções sociais - produtos aparecem dentro de determinados contextos sociais, sendo consumidos por grupos específicos. Também são apresentados produtos que são reconhecidos como adequados para serem utilizados pela pessoa que assiste ou ainda, são desejados exatamente por pertencerem ao universo de outros segmentos sociais. Ao transitar de volta para seu ambiente familiar, a empregada exerce o papel de mediadora, levando informações sobre este outro mundo, o que não significa uma assimilação passiva, mas sim uma "abertura para o consumo". Um dos pontos que chamam atenção no relato das empregadas (BARROS, 2007) é o modo pelo qual a discussão sobre a narrativa das novelas proporciona um comentário sobre a moralidade dos personagens e a identificação com seu próprio mundo, tanto nas conversas na casa da empregada, quanto nos seus diálogos com a patroa, em um processo de reinterpretação de conteúdos ficcionais mais "modernizantes" a partir da sua própria ótica cultural, comparativamente mais hierárquica e "tradicionalista”.

Tanto no seriado analisado quanto na pesquisa realizada sobre empregadas, a dimensão do consumo aparece como meio privilegiado de expressão de diferenças sociais. Enquanto a análise da narrativa do seriado aponta para a reafirmação de um universo estável, onde a mudança ocorre para que as coisas voltem ao "seu lugar", uma imersão na experiência de "assistir televisão" junto às empregadas revela que o "repertório compartilhado" (HAMBURGER, 1998) não dilui magicamente barreiras sociais, mas cria um 
campo de possibilidades de diálogos e "aberturas" para o consumo (BARROS, 2007), o que pode ser entendido como uma relativa aproximação entre mundos distintos.

\section{Referências}

AGUIAR, Neuma (org). Hierarquia em classes. Rio de Janeiro: Zahar, 1974.

ALMEIDA, Heloísa B. Telenovela, consumo e gênero. Bauru, SP: EDUSC, 2003.

BARROS, Carla. Trocas, hierarquia e mediação: dimensões culturais do consumo em um grupo de empregadas domésticas. Tese (Doutorado em Administração). Rio de Janeiro: COPPEAD/UFRJ, 2007.

BORDIEU, Pierre. Le sens pratique. Paris: Minuit, 1980.

CAMPBELL, Colin. A ética romântica e o espírito do consumismo moderno. Rio de Janeiro: Rocco, 2001.

DAMATTA, Roberto. Carnavais, malandros e heróis: para uma sociologia do dilema brasileiro. 3. ed. Rio de Janeiro: Zahar, 1981.

. O que faz o Brasil, Brasil? .7. ed. Rio de Janeiro: Rocco. 1994.

DOUGLAS, Mary; ISHERWOOD, Baron. O mundo dos bens: para uma antropologia do consumo. Rio de Janeiro: UFRJ, 2004. 
DUMONT, Louis. Homo hierarchicus. Paris: Gallimard, 1972.

GOMES, Laura Graziela. Novela e sociedade no Brasil. Niterói, RJ: EdUFF, 1998.

HAMBURGER, Esther. "Diluindo fronteiras: a televisão e as novelas no cotidiano". In: NOVAES, Fernando A.(dir.); SCHWARCZ, Lilia M. (org.). História da vida privada no Brasil: contrastes da intimidade contemporânea. São Paulo: Companhia das Letras, 1998. vol. 4.

. O Brasil antenado: a sociedade da novela. Rio de Janeiro:

Jorge Zahar, 2005.

LÉVI-STRAUSS, Claude. O pensamento selvagem. São Paulo: CEN, 1970.

MACHADO, Arlindo; VÉLEZ, Marta Lucia. O quartel das feias. Cadernos de televisão. n. 2, ago. 2008.

MASLOW, Abraham. Motivation and personality. New York: Harper\&Row, 1954.

MILLER, Daniel. Stuff. Cambridge: Polity Press, 2010.

ROCHA, Everardo. Magia e capitalismo. São Paulo: Brasiliense, 1985.

SAHLINS, Marshall. Cultura e razão prática. Rio de Janeiro: Zahar Ed., 1979. 
SARTI, Cynthia. A família como espelho: um estudo sobre a moral dos pobres. Campinas, São Paulo: Autores Associados, 1996.

SLATER, Don. Cultura do consumo \& modernidade. São Paulo: Nobel, 2002.

SUAREZ, Maribel; MOTTA, Paulo César; BARROS, Carla. Consumo e castigo: um retrato das relações de consumo no seriado A Diarista. In: ROCHA, Angela; SILVA, Jorge. (Orgs). Consumo na base da pirâmide: estudos brasileiros. Rio de Janeiro: Mauad X, 2009.

VELHO, Gilberto; KUSCHNIR, Karina (Orgs.). Mediação, cultura e política. Rio de Janeiro: Aeroplano, 2001. 


\section{Já vale tudo? \\ Dilemas éticos e suas representações midiáticas em tempos de paradigmas \\ deslizantes}

Ana Lucia Enne

\section{Introdução}

Em 2010/2011, o Canal Viva, mantido pela Rede Globo de Televisão com programação na maior parte constituída por produtos antigos desta emissora, reexibiu, no horário da madrugada, a telenovela "Vale Tudo", de Gilberto Braga (em coautoria com Aguinaldo Silva e Leonor Bassères), veiculada originalmente em 1988/1989 no horário nobre das 20 h. ${ }^{6}$ O sucesso da audiência levou a novela aos principais jornais e revistas, sendo também assunto diário nos comentários em diversas redes sociais, como o Twitter e o Facebook. Seu plot principal, segundo Gilberto Braga, era discutir "até que ponto valia ser honesto no Brasil"? A trama,

6 Confira: http://pt.wikipedia.org/wiki/Vale_Tudo - Acesso em: maio 2012.

7 Idem. 
girando então em torno de questões éticas e dramas familiares no Brasil da década de 80 , chamou a atenção por sua atualidade e colocou em cena novamente personagens que fizeram história na tevê brasileira, como os vilões Odete Roitman, Marco Aurélio e Maria de Fátima (vividos respectivamente por Beatriz Segall, Reginaldo Faria e Glória Pires), os honestíssimos Raquel Acioly, Poliana, Tia Celina e Solange (interpretados por Regina Duarte, Pedro Paulo Rangel, Nathalia Timberg e Lidia Brondi) e os conflitantes Ivan Meireles e Heleninha Roitman (Antonio Fagundes e Renata Sorrah).

No entanto, chamou-nos a atenção, inclusive por adesão pessoal, a reação de muitos que acompanharam a novela na exibição original e novamente em 2011, revelando nas redes sociais seu espanto por estarem se identificando e mesmo torcendo pelos vilões antes execrados, ao mesmo tempo em que não se percebiam identificados com os até então heróis da história. Isso, de alguma forma, já havia acontecido na primeira exibição, mas de forma ainda branda. Na reexibição, este processo se adensou fortemente. Se o produto era o mesmo, o que poderia estar causando uma mudança tão acentuada na recepção daquelas mensagens, senão uma transformação no contexto social e cultural em que aqueles espectadores viviam em 1988 e em $2010 ?^{8}$ Essa expressiva alteração na leitura do público nos trouxe a inquietude que agora motiva este artigo. Diante de um deslizante contexto da pós-modernidade, como abordaremos no decorrer deste artigo, valores que no contexto original

8 Nossas observações são qualitativas e refletem, evidentemente, uma limitada compreensão da recepção da novela, não tendo, neste sentido, pretensões quantitativas, abrangentes ou totalizantes. São somente insights que gostaríamos de partilhar. Assim, reconhecemos que existem limitações em termos de perfil e abrangência em nossas referências. Agradeço as ponderações feitas acerca deste ponto nas discussões realizadas no GT Antropologia da Comunicação de Massa na ABA 2012. 
da novela operavam como sentidos mais fixados e reconhecidos em termos de bom e mau comportamento, agora entravam em um terreno de relativismo e mesmo inversão.

No mesmo ano de 2010, estreava nos cinemas o filme norte-americano "A rede social" ("The social network", dirigido por David Fincher), que conta a trajetória de Mark Zuckerberg (vivido no filme porJesse Eisenberg), o proprietário da rede social Facebook. ${ }^{9}$ Baseado em fatos reais, a trama é recheada de situações em que o personagem central passa para trás, na fundação e consagração do site mundialmente popularizado, amigos e sócios. Estamos diante de um cenário de quebra de parâmetros éticos, em que mentiras, golpes e traições são comuns. Diante do mesmo, como se constroem as representações acerca dos personagens? Pretendemos, neste artigo, explorar como um produto construído já em um contexto de "modernidade líquida", nos termos propostos por Z. Bauman (2000), ou de "corrosão do caráter", como afirma Richard Sennett (1999), apresenta seus personagens e as questões éticas, estabelecendo um contraponto com a narrativa desenvolvida em "Vale Tudo", no contexto dos anos 80. Acreditamos que as reações do público, acima descritas, funcionarão como um alinhave interessante para nossa reflexão.

Assim, como indicamos em nosso resumo, pretendemos, nesse artigo, abordar como os deslocamentos nas fronteiras referentes aos paradigmas éticos de uma perspectiva do tipo moderna para outra do tipo pós-moderna permitiram também um deslocamento nas representações midiáticas acerca dos valores éticos e suas implicações nas subjetividades e sociedades contemporâneas. Através da comparação proposta, pretendemos mapear como as representações midiáticas permitem compreender as práticas socioculturais nas quais se inserem e, para além disso, como formatos veiculados

9 Cf.http://pt.wikipedia.org/wiki/A_Rede_Social - Acesso em: maio 2012. 
na cultura de massa contribuem para a consolidação de determinadas visões de mundo acerca de temáticas deslizantes por excelência.

\section{"Vale Tudo" e os "dilemas éticos da cultura brasileira"}

No mesmo ano da veiculação da novela "Vale Tudo", especificamente em 1988, Jurandir Freire Costa publicava A ética e o espelho da cultura, em que discutia, através de uma série de artigos, questões éticas da cultura brasileira no contexto dos anos 80 . Pretendemos destacar aqui a parte 2 de sua "Introdução", denominada justamente "Dilemas éticos da cultura brasileira", título ao qual recorremos também para indicar do que se trata esta parte de nosso artigo.

Para Jurandir Freire Costa, estaríamos, naquele momento histórico, frente a um "dilema ético", em que "os princípios morais da cultura perdem a força que deveriam ter na direção das ações práticas" (1988, p.38). Era, portanto, na concepção de Freire Costa, um momento de crise, e como tal, algo ainda não resolvido, em transição, sem definição mais concreta. Assim, "existe uma "crise nos valores éticos" quando os indivíduos não mais se orientam pelos ideais de conduta moral aceitos e não sabem ou não conseguem propor novos ideais compatíveis com a tradição cultural" (id.).

Neste momento de transição, Freire Costa diagnostica duas hipóteses para explicar as causas de crise e, como consequência, as formas de resolvê-las. Partindo das observações foucaultianas, chama a primeira de "hipótese jurídica". A partir dessa perspectiva, a ética (ou a moral):

É vista como um código de regras ideais de conduta. A crise é o conflito com o código, determinado pelo afastamento das condutas práticas do modelo ideal. O conceito central neste conflito 
é o da transgressão (...). Pensamos que não agimos como seria bom agir porque uns transgridem as normas por cinismo e outros por ignorância (COSTA, 1988, p.39).

Neste sentido, há um incômodo pela sensação de falta: "falta de culpa; de vergonha; de decoro; de compromisso; de responsabilidade; de solidariedade; de sentido cívico; de sensibilidade política etc." (1988, p.40) A solução, portanto, deveria necessariamente passar pela "restauração dos valores perdidos" (id)

Neste caminho, a busca pelos valores tradicionais seria sempre ameaçada pelo risco conservador, embora Jurandir Freire Costa (1988, p.41) nos lembre que "fazer valer a autoridade da tradição moral, ainda que pela força se for preciso, não aponta compulsoriamente para o conservadorismo". No entanto, esse seria um risco sempre presente.

Por outro lado, existiam os que percebiam a crise dos valores éticos por um viés positivo, exatamente pelo seu potencial de contestação do sistema estabelecido. Jurandir Freire Costa se refere a esta visão como "hipótese produtiva". Aqueles que a defendiam percebem-se não como infratores, mas como "criadores de condutas inovadoras positivas". Nas palavras do autor, trata-se de conceituar os modos tradicionais de agir e pensar como "preceitos menores", ou seja:

Princípios idealistas, fantasiosos, ineficientes, puritanos, franciscanos, repressivos, obsoletos, em suma, como conselhos edificantes, do "catecismo dos perdedores”. Não só os cínicos - cegos em relação a valores - e os miseráveis - analfabetos em relação a valores - opõem-se à tradição moral que conhecemos. Os homens "felizes", "os vencedores”, como se costuma dizer, também. É 
o advento da "consciência feliz" na "ideologia do bem-estar. (COSTA, 1988, p.42).

Tal "ideologia do bem-estar" se identificaria como valores "modernizadores", que em nossa leitura já apontam para várias das características listadas por estudiosos da pós-modernidade, tais como:

Ser neo-liberal em economia; ser a favor da privatização de tudo que possa vir a dar lucro; cultuar a tecnologia da informática e dos multimídias; ser "liberado"em matéria de sexualidade; adotar o consumo ostentatório como estilo de vida; construir identidades pessoais pela filiação a grupos particularizados por marcas corporais, traços étnicos, convicções religiosas etc; tornar-se praticante e consumidor das inúmeras tecnologias de bem-estar físico-mental e, por fim, fazer do sucesso na mídia sintoma de auto-realização e da linguagem da publicidade, meio intelectual privilegiado das discussões culturais (COSTA,1988, p.43, grifos do autor).

A partir destas observações, Freire Costa descreve essa ideologia como apolítica, particularista, determinista e autoritária. No entanto, atém-se mais detalhadamente no ponto que nos interessa para esse artigo: a construção da imagem do sucesso. Segundo ele, no ethos que descreve, "os indivíduos não cultuam mais nem virtudes públicas, nem privadas” (1988, p.45). E isso altera substancialmente o que concebe como "heroísmo".

$\mathrm{Na}$ ideologia do bem-estar, o que conta não é a virtude, é o sucesso. A distância ética entre os dois é enorme. O sucesso é indiferente à virtude. Seu parâmetro é a visibilidade. Donde a simbiose com 
a publicidade ou o "espaço publicitário". O sucesso vive da publicidade e ambos dependem do mercado de objetos. (...) Não se pede mais que pense em qual é a melhor escolha para ele e para o outro, pede-se que calcule qual a melhor tática para ser "bem-sucedido". (...) O sucesso tornou-se um meio "naturalizado" ou "socializado" de construção de identidade pessoal. A diluição do sujeito na moral do consumo e do mercado faz do sucesso uma das poucas condições de posse da admiração do outro. Admiração desejada porque significa acesso a um maior número de bens materiais e à distinção pelos signos do consumo ostentatório. (COSTA, 1988, p.45).

Voltemos agora à novela "Vale Tudo". Há claramente, em seu enredo, a tematização dos dilemas éticos apontados por Jurandir Freire Costa. De um lado, estão os personagens "éticos", que se pautam por valores tradicionais e por condutas que prezam valores como honestidade, honradez, solidariedade, amizade, fidelidade etc.; de outro, os personagens que estão mais diretamente ligados à descrição da "ideologia do bem-estar", em que o sucesso (relacionado claramente à possibilidade de ascensão, de manutenção do poder econômico a qualquer preço, de fazer parte da elite econômica) é a meta e a justificativa para qualquer atitude moralmente condenável. São visões de mundo radicalmente opostas, simbolizadas em seus extremos pelos personagens éticos (em especial, Raquel Acioly) e pelos personagens para os quais "vale tudo" para conseguir seus objetivos (em especial, Odete Roitman e Maria de Fátima). Em meio a esses polos demarcados, encontramos um personagem ambíguo, Ivan Meireles, que oscila entre posturas éticas (e o amor de Raquel) e posturas antiéticas (com possibilidades de ascensão e sucesso na carreira e na vida econômica). 
Quando exibida, em 1988, o repúdio à vilania, embora as performances dos atores fossem muito aplaudidas, foi claro. Raquel era a grande heroína nacional, a que vinha de uma situação difícil (perdeu a casa depois que sua traiçoeira e ambiciosa filha Maria de Fátima vendeu seu único bem para fugir para o Rio de Janeiro e ficar rica), tendo inclusive que vender sanduíches na praia para sobreviver, e que com trabalho honesto, amigos leais, pensamento positivo e "muita garra" (o que nos faz lembrar de slogan recente que visa a celebrar essa postura: "sou brasileiro e não desisto nunca") se transformou em vencedora e proprietária de uma empresa de alimentos. Raquel simbolizava a ascensão pelo trabalho honesto, pela vida correta, generosa com amigos e empregados, sem nunca incorrer em falhas morais mesmo perdendo, com isso, seu amor e sendo desprezada pela própria filha. Por outro lado, Maria de Fátima, a filha ingrata, simbolizava o desejo de sucesso, poder e dinheiro, não importa a que preço. O Brasil de fins de 1980, em termos de opinião pública, não tinha dúvidas: a heroína era Raquel, a vilã Maria de Fátima. E Ivan oscilava entre os dois modelos de conduta, simbolizando no mundo ficcional os dilemas éticos mapeados no contexto sociocultural daquele período no texto de Jurandir Freire Costa.

Gostaríamos de nos focar, neste artigo, no capítulo final da novela. Em "Vale Tudo", a grande vilã, Odete Roitman, já havia sido assassinada, mas não por suas maldades ou crimes, e sim por um acaso fatal (foi confundida com uma possível amante de Marco Aurélio e morta com tiros pela esposa Leila, vivida por Cássia Kiss). Não se tratava, no sentido moral, de uma punição. Os outros dois vilões, Marco Aurélio e Maria de Fátima, "se dão bem". Em cena famosa, Marco Aurélio, com a esposa e o enteado, foge para o exterior de avião com o dinheiro que havia roubado da TCA, firma de aviação da família Roitman na qual era vice-presidente, dando 
uma "banana" para o Brasil e para o público brasileiro. Maria de Fátima, por sua vez, depois de quase se arrepender de suas artimanhas que só rendiam insucessos, consegue se casar, em um arranjo com seu amante Cesar (Carlos Alberto Ricceli), com um príncipe da Lombardia, que, como descreve Tia Celina no último capítulo, entre espantada e admirada, é "de uma das melhores casas da Lombardia", inclusive iniciando "carreira na política". Assim, "vai ser um casamento grandioso, convidados do mundo inteiro, ampla cobertura na imprensa internacional". ${ }^{10}$ Seu projeto de ascensão se consagrava: rica, iria para o exterior, viver na Europa, seu grande sonho. Ou seja, os vilões não são punidos.

Mas a última cena é dedicada à Raquel e ao seu amado Ivan. Acreditamos que as cenas finais têm um papel fundamental na performance discursiva, fechando os sentidos e conformando a moral pretendida, dentre de uma representação normativa. Ivan, depois de confessar ter praticado crime de suborno, passa dois anos na prisão. Na cena final, Ivan já saiu da prisão, um homem livre que pagou pelo seu crime, tendo encontrado Raquel à sua espera no portão do presídio. Apaixonados, felizes, livres para viver seu amor e uma vida tranquila, pautada pelos valores honestos e vitoriosos de Raquel, caminham despreocupados pelo calçadão festivo do Arpoador, cercados por brasileiros comuns, simples, vivendo de maneira correta sua vida, ao som de "isso aqui, oô, é um pouquinho do Brasil, iaiá, um Brasil que canta e é feliz, feliz, feliz... é também um povo de uma raça que não tem medo de fumaça e não se entrega não", tomando sorvete, abraçados, prontos para serem felizes no Brasil que se esperava construir dali para frente, a partir desses parâmetros éticos. ${ }^{11}$ Os vilões ficam impunes, mas não lhes cabe seu país. Só lhes resta

10 Cf.http://www.youtube.com/watch?v=pnFab5S1a3E - Acesso em: maio 2012.

11 Idem. 
partir. O Brasil, diz a mensagem final, é para os brasileiros éticos, corretos, honestos e trabalhadores.

\section{"Já vale tudo?" ou "a corrosão do caráter"}

Cerca de dez anos depois da exibição da novela e da publicação do livro de Jurandir Freire Costa, Richard Sennett lança $A$ corrosão do caráter. Seguindo a linha que já vinha desenvolvendo em trabalhos anteriores, identifica que há uma perda da dimensão política solidária na sociedade contemporânea, o que irá se refletir em vários aspectos da vida social, como as relações de trabalho e as pessoais. Sobre essas, vamos nos debruçar aqui. Analisando a flexibilidade que irá marcar o capitalismo no período estudado, Sennett considera que:

"Talvez o aspecto da flexibilidade que mais confusão causa seja seu impacto sobre o caráter pessoal. Os antigos anglófonos, e na verdade escritores que remontam à antiguidade, não tinham dúvida sobre o significado de "caráter": é o valor ético que atribuímos aos nossos próprios desejos e às nossas relações com os outros. Horácio escreve que o caráter de alguém depende de suas ligações com o mundo. (...) Caráter são os traços pessoais a que damos valor em nós mesmos, e pelos quais buscamos que os outros nos valorizem". (SENNETT, 1999, p.10).

Neste sentido, a definição se aproxima daquela dada por M. Pollak à identidade, em que essa teria um:

Sentido de imagem de si, para si e para os outros, isto é, uma imagem que uma pessoa adquire ao 
longo da vida referente a ela própria, a imagem que ela constrói e apresenta aos outros e a si própria, para acreditar na sua própria representação, mas também para ser percebida da maneira como quer ser percebida pelos outros. (POLLAK, 1992, p.204).

Ambas as definições apontam para o caráter construído dessa imagem pessoal que buscamos apresentar para os demais, como formas públicas de nosso self.

Para Sennett, a flexibilidade das sociedades atuais enfraqueceu o caráter, pois cessam as necessidades de uma apresentação mais coerente e continuada do self, de acordo com valores socialmente partilhados. Assim, ele afirma:

Como decidimos o que tem valor duradouro em nós numa sociedade impaciente, que se concentra no momento imediato? Como se podem buscar metas de longo prazo numa economia dedicada ao curto prazo? Como se podem manter lealdades e compromissos mútuos em instituições que vivem se desfazendo ou sendo continuamente reprojetadas? (SENNETT, 1999, p.10-11).

Assim, a flexibilidade das relações cria a possibilidade do enfraquecimento do caráter enquanto princípio ético. Em suas palavras:

Esse é o problema do caráter no capitalismo moderno. Há história, mas não narrativa partilhada de dificuldade e, portanto tampouco destino partilhado. Nessas condições, o caráter se corrói; a pergunta “Quem precisa de mim?” Não tem resposta imediata (1999, p.175-176). 
De forma semelhante, Z. Bauman (1998) lamenta a perda das referências coletivas e solidárias na modernidade líquida, em que as relações sociais se pautam pela fluidez e pelo desconforto com os parâmetros éticos modernos. Especialmente atravessadas pelo consumo, as relações sociais se tornam competitivas, discriminatórias, separatistas, não coletivizadas. Há um desejo permanente, diz Bauman, de se tornar "consumidor", mas nem todos conseguem alcançá-lo. Isso cria, em sua concepção, sociedades divididas, vidas despedaçadas, indivíduos sem âncoras e preocupados com os signos do sucesso e do status.

Há no contexto pós-moderno descrito pelos dois autores, a consagração da "ideologia do bem-estar". O sucesso, pessoal e financeiro, é a meta a ser alcançada a qualquer custo. E sua posse, não importa por qual via, é legitimada em termos gerais pela grande mídia e pelo senso comum. Neste sentido, o filme "Rede Social" é bastante ilustrativo.

Trata-se, como dissemos anteriormente, de uma narrativa acerca do processo de construção de um site de relacionamentos, que do âmbito interno de uma universidade norte-americana, se propaga como um fenômeno global, atingindo quase um bilhão de usuários em $2012^{12}$. No entanto, os bastidores de criação do Facebook são recheados de traições e golpes de parte de seu proprietário, Mark Zuckerberg. Segundo o filme e diversas fontes, ele teria roubado a ideia dos gêmeos Cameron e Tyler Winklevoss e de seu parceiro Divya Narendra, que inclusive o processaram por isso, e depois teria lesado seu amigo e sócio, o brasileiro Eduardo Saverin, cujo apoio financeiro teria sido vital para a realização do projeto em seu início.

12 Cf. http://www.jb.com.br/ciencia-e-tecnologia/noticias/2012/05/14/mundotem-1-bilhao-de-usuarios-de-redes-sociais-diz-estudo/ - Acesso em: maio 2012 
Zuckerberg é acusado em vários processos e condenado a pagar cerca de 100 milhões de dólares, a partir de acordos entre as partes. É, portanto, publicamente alguém cuja ascensão se dá por golpes e roubos. No entanto, é considerado uma bem-sucedida personalidade mundial, celebrado e valorizado por sua "criação", mas principalmente por sua trajetória de sucesso, independentemente dos meios utilizados para alcançar tais fins. O slogan do filme é claro nesse sentido: "Você não consegue fazer 500 milhões de amigos sem fazer alguns inimigos". ${ }^{13}$ Portanto, a consagração quantitativa requer algumas perdas qualitativas, e isso é parte do jogo pelo sucesso.

Na representação cinematográfica, Zuckerberg não demonstra expressivamente nenhuma manifestação de constrangimento ou culpa.É claramente um "esperto", alguém que sabe usar as oportunidades para "se dar bem", às custas de lealdade, amizade, fidelidade etc. Eduardo, o sócio brasileiro lesado, em um determinado momento lamenta que seu pai (e, de forma geral, o senso comum) o considere um idiota por ter sido passado para trás daquela forma. Neste sentido, há uma inversão considerável nas formas de representação encontradas em "Vale Tudo" em sua leitura original. O honesto passado para trás lamenta ser visto como um idiota; o "esperto" sem caráter é celebrado como vencedor.

Vamos nos focar, novamente, na cena final, agora do filme, para tentarmos perceber como se fecham, narrativamente, os sentidos propostos. Na sede do Facebook, sozinho em uma cadeira, Zuckerberg tenta adicionar a garota que tentou conquistar, tendo sido repudiado e chamado por ela de "babaca", no Facebook. A cena mostra Zuckerberg, solitário, na cadeira, no escritório vazio, apertando continuamente a tecla de atualização do FB. Em tese, a

13 Cf. http://pt.wikipedia.org/wiki/A_Rede_Social - Acesso em: maio 2012. 
mensagem final é: o crime não compensa, o que ele rende é solidão. Frases soltas indicam o quanto ele teve que pagar para os gêmeos e o que aconteceu com Eduardo. E dados sobre o FB: "Facebook tem 500 milhões de usuários em 207 países. Está avaliado em 25 bilhões de dólares”. Mas eis que aparece a frase final. Apoteótica e taxativa, fechando com o rosto do ator em close: "Mark Zuckerberg é o mais jovem bilionário do mundo". 14 No plano afetivo, ser "babaca” pode até não compensar, mas quem se importa com isso? No plano econômico, medida do sucesso e da projeção da imagem, acesso ao mundo dos bens e provavelmente de mulheres, Zuckerberg é o mais bem sucedido de todos, o grande vitorioso, o que "se deu bem".

Voltemos à "Vale Tudo", agora em sua fase de reapresentação no canal Viva, em 2011. A reação do público estonteia: os antigos heróis e seus valores são chatos, ultrapassados, merecem sofrer. A hora é de celebrar os "espertos", os que lutam "para se dar bem", os que sabem o que querem e não medem esforços para conquistar o sucesso, o poder, o dinheiro. Maria de Fátima, tal qual Mark Zuckerberg, é a nova heroína. Na verdade, em capítulo visionário no decorrer da novela, Gilberto Braga já havia profetizado essa mudança. Em uma cena no apartamento de Cesar, Olavo (vivido por Paulo Reis), seu parceiro picareta nas armações, comenta que admira Maria de Fátima por sua coragem e talento. Ele diz que ela irá longe e que o Brasil ainda vai reconhecer Maria de Fátima por suas atitudes. E vaticina afirmando que Maria de Fátima é uma heroína pós-moderna. ${ }^{15}$

14 Cf. http://www.youtube.com/watch?v=8UhONY3-1os - Acesso em: maio 2012, tradução livre.

15 Capítulo sem referência, assistido pela autora no decorrer da reapresentação no canal Viva. 
Consideramos essa cena um marco do que tentamos argumentar nesse artigo. Há uma mudança expressiva nos modos de ver o mundo quando comparamos o cenário dos anos 1980 com o fim do século XX. Lá é possível perceber, como bem delimitou Jurandir Freire Costa, uma crise em andamento, um dilema ético entre valores tradicionais e novas formas de agir e pensar. No cenário mais recente, ao que parece, esse dilema já vem se resolvendo, com a paulatina consagração dos valores associados à "hipótese produtiva" e à "ideologia do bem-estar" que o autor descreveu.

\section{Algumas observações finais}

Tentamos mapear, neste artigo, como duas formas de ficcionalização, uma telenovela de 1988 e um filme de 2010, operam com representações complexas no que tange a questões éticas fundamentais. Assim, nosso trabalho permite, ainda que de forma não explorada em razão dos limites de tempo e espaço aqui destinados, uma abordagem acerca da relação entre a cultura de massa e o jogo representacional das condições sócio-históricas-culturais em que suas produções são criadas e exibidas. Sem operarmos com visões dicotômicas acerca do papel dos meios de comunicação de massa nas sociedades em que se inserem, entendemos que seus produtos tanto refletem como servem de modelo para formas de ver o mundo, em uma relação dialética. Assim, se "Vale Tudo", nos anos 1980, traduz dilemas éticos que atravessam a sociedade naquele período, funciona também como diretriz comportamental, indicando via moral em sua cena final o que compensa de fato; da mesma forma, "A Rede Social", ao mesmo tempo em que narra a trajetória deslizante em termos morais de seu personagem principal, consagra este estilo de vida associado ao sucesso financeiro através de sua cena final. Ambos, neste sentido, são performativos, são estratégias 
linguísticas que não só representam, mas criam mundo, não só se inserem e dialogam com a realidade, mas a constroem socialmente no campo discursivo.

Mas a reação da plateia nos mostra que toda construção discursiva opera no contexto da interpretação e da recepção. Assim, é na reconfiguração que a pedagogia moral de um produto veiculado em um meio de comunicação de massa, como a televisão, pode se confirmar ou não. A normatização performatizada no final de "Vale Tudo" encontra eco em parte da recepção dos telespectadores dos anos 80 , mas é renegada por parte da audiência que assiste à sua reexibição. Neste sentido, o tempo é condição fundamental para a narrativa se configurar e criar mundo, lembrando mais uma vez a teoria da tríplice mimese de Paul Ricoeur (1984).

Sem dúvida, é possível perceber como os jogos narrativos deslizaram, em termos representacionais, no que tange aos valores éticos consagrados na história moderna ocidental, quando comparamos os dois produtos. Neste sentido, as representações parecem ter acompanhado os deslizamentos da vida pós-moderna, em que os valores tendem a se apresentar mais flexíveis e impermanentes. Trata-se de um processo ainda aberto, em permanente desconstrução e reconfiguração, mas que de qualquer forma parece apontar para uma fragilidade cada vez maior dos valores mais tradicionais como norteadores da ação dos sujeitos na vida privada e pública, com a apologia de valores menos compromissados com a vida coletiva e com o outro, voltados mais especificamente para a vitória pessoal, cada vez mais associada à conquista do poder aquisitivo e do sucesso publicitário.

Jurandir Freire Costa e Richard Sennett, nossas referências principais neste artigo, parecem perceber, em dois momentos distintos (fins de 80 e fins de 90), esta tendência. E como estamos elegendo aqui cenas finais para pensarmos a "moral da história", 
também em suas falas finais, respectivamente em seu artigo (Costa) e em seu livro (Sennett), deixam perceber suas posições e visões de mundo acerca do que está se passando com os valores éticos neste processo histórico que descrevem. E, em nossa interpretação, o que os une é o tom de lamento e inquietação.

Assim, Jurandir Freire Costa indaga, em seu último parágrafo:

Abdicando da ideia de sujeito moral em favor de identidades parcializadas, construídas pelas regras do mercado de bens ou pelas marcas da realidade em nossos corpos, atravessamos uma fronteira sem conhecer o outro lado. Nada mais fácil do que gozar com a crueldade infligida ao outro. (...) Não se abandonam impunemente estas crenças. É preciso que o que entendemos por amor, amizade, solidariedade, fraternidade, generosidade e, inversamente, por crueldade, indiferença etc., nada mais signifiquem para que uma outra forma de vida possa tomar o lugar da atual. Se isto vier a acontecer, o mundo não será mais o mesmo. Muitos de nós não saberiam o que fazer de um mundo assim. Como viver num mundo assim?. (COSTA, 1988, p.55).

Sennett considera que uma vida sem solidariedade gera uma impossibilidade em termos de contrato social, o que fadaria o regime que o sustenta ao fracasso, se referindo, especificamente, ao capitalismo. E profere: "sei que um regime que não oferece aos seres humanos motivos para ligarem uns para os outros não pode preservar sua legitimidade por muito tempo" (1999, p.176).

Entendemos as inquietações dos dois autores. E acreditamos que esse artigo é também uma forma de expressar as nossas. 


\section{Referências}

BAUMAN, Z. Comunidade. A busca por segurança no mundo atual. Rio de Janeiro: Jorge Zahar Editores, 2003.

. Globalização: as consequências humanas. Rio de Janeiro:

Jorge Zahar, 1999.

. Modernidade líquida. Rio de Janeiro: Jorge Zahar, 2000.

CASTELLS, Manuel. A sociedade em rede. A era da informação: economia, sociedade e cultura, v.1. São Paulo: Paz e Terra, 1999.

COSTA, Jurandir Freire. A ética e o espelho da cultura. Rio de Janeiro: Rocco, 1988.

GIDDENS, A. As consequências da modernidade. São Paulo: UNESP, 1994.

POLLAK, Michel. Memória e identidade social. Revista Estudos Históricos, v.5, n. 10. Rio de Janeiro: FGV, 1992.

RICOEUR, Paul. Tempo e narrativa. Campinas: Papirus, 1984.

SENNETT, Richard. A corrosão do caráter. Rio de Janeiro: Record, 1999. 


\section{Jovens rurais e as desigualdades sociais do campo representadas no Jornal Nacional}

Julia Schnorr

\section{Introdução}

Os meios de comunicação já estão inseridos no cotidiano da sociedade. Do rádio à comunicação através de telefones móveis, a tendência é a inserção mais profunda em nosso cotidiano, especialmente com as novas plataformas. A geração atual desconhece uma vida sem televisão. Embora existam o telefone celular, smartphones e o computador, a televisão ainda é importante para a conformação de comportamentos e como meio de informação de diversas famílias, em especial no meio rural e na classe popular. Os jovens, seja no campo ou na cidade, cresceram com a assistência da televisão. $O$ que ela ensinou a esses jovens? O eletrodoméstico já ocupou grande parte do lazer dos jovens rurais. $\mathrm{O}$ tempo em família ainda é compartilhado com a assistência da televisão. O que a mídia construiu através do agendamento de notícias sobre o meio rural? E sobre as desigualdades sociais? 
A partir da afirmação de que a mídia tem um papel importante na sociedade, bem como uma possibilidade de agendamento das pautas, o trabalho busca identificar como os jovens leem as notícias sobre as ruralidades no Jornal Nacional, o telejornal com maior audiência no Brasil. Para isso, detemos a atenção na construção das representações midiáticas sobre o modelo de desenvolvimento rural e sobre o pequeno e o grande proprietário. Dessa forma, entrevistamos jovens que moram em localidades rurais de Santa Maria (RS), especificamente aqueles filhos de assentados da reforma agrária ou que estejam envolvidos com grupos de Economia Solidária. Pedro Henrique, 17 anos, é filho de assentados. No mesmo local em que vive, no assentamento Carlos Marighella, cresceram Raimundo e Lúcia, ambos de 18 anos. Já Igor, 17 anos, faz parte de um grupo de Economia Solidária, o Terra Viva.

O Jornal Nacional, programa analisado junto aos jovens, é parte da programação da Rede Globo e centra-se desde 1969, ano de sua construção, como um instrumento de consolidação da unidade nacional. Anderson (2008, p.32), ao utilizar o conceito de comunidade imaginada, referindo-se à nação, afirma que "mesmo os membros da mais minúscula das nações jamais conhecerão, encontrarão, ou sequer ouvirão falar da maioria de seus companheiros, embora todos tenham em mente a imagem viva da comunhão entre eles." Como pontos-chaves da formação da nação, o historiador cita a língua impressa através de livros. Podemos analisar a televisão através desse viés. Quando a Rede Globo inaugurou no Brasil, a integração nacional acabou sendo um dos objetivos do canal. O Jornal Nacional, um dos seus principais programas, foi o carro-chefe.

A partir do momento em que tratamos a televisão sob o aspecto da vida cultural, ou seja, como parte da cultura brasileira, ela torna-se fundamental para compreender a sociedade do país. 
Vizeu (2009, p.77) entende a televisão como um local de referência, como construções didáticas, pois "a televisão na sociedade contemporânea cumpre essa função de reforçar que a realidade existe e que não estamos sozinhos no mundo." Nesse sentido, Maia (2009, p.176) versa sobre as particularidades do telejornalismo em nosso país:

\begin{abstract}
Uma vez encontrado o lugar da TV na vida das pessoas, pensamos também na representação do telejornal para os brasileiros. Dentre uma população com precário hábito de leitura, o noticiário televisivo ganha status de local de orientação, ao qual homens e mulheres recorrem nas sociedades complexas a fim de obter informações para compreender seu cotidiano, seu mundo.
\end{abstract}

A televisão, dessa forma, tem seu lugar na cultura brasileira, com seus produtos trabalhando para a nossa de construção da realidade. Ela é, igualmente, ponto referencial para diversos indivíduos, pois serve como "válvula de escape", conforme apontam os depoimentos que Travancas (2007 apud VIZEU, 2009, p.78) traz:

Não é à toa que alguns comentavam que, embora o jornal mostrasse tragédias e notícias negativas, assistir ele dava uma sensação de tranquilidade. $\mathrm{E}$ comentavam que viam o Jornal Nacional também para relaxar de suas rotinas estressantes e corridas de uma grande metrópole.

Seja como forma de entretenimento, informação ou como referência de orientação, a assistência da televisão é importante no Brasil, pois dá auxílio para compreender de um ponto de vista a realidade do país. Na mídia brasileira, podemos encontrar casos 
em que as classes populares são ridicularizadas ou têm suas vidas particulares expostas, como no Pânico na TV16 e no Programa do Ratinho. Entendemos que as representações midiáticas tornam familiar algo que não costuma ser, como a riqueza para as classes populares e a pobreza para as classes altas. No entanto, Bourdieu (1991, p.448) afirma que as classes dominantes constroem elas mesmas suas representações, fazendo com que os "dominados" fiquem em uma posição de negociação ou resistência simbólica.

Em nossa pesquisa, trabalhamos a desigualdade como portadora de um significado social. Ela não surge naturalmente, não é "inerente à existência da totalidade ou de uma parcela da humanidade em um determinado tempo e lugar; ao contrário, a pobreza é produzida e reproduzida socialmente. "(CAMPOS, 2011, p.51). Por isso, interessa-nos investigar as leituras dos jovens rurais sobre as representações midiáticas da desigualdade social do campo.

\section{Material e métodos}

Temos como amostra inicial quatro jovens que são ou foram moradores e/ou trabalhadores em áreas rurais e que tenham ligações familiares com esse meio, como por meio de familiares. Pedro Henrique, Lúcia e Raimundo cresceram juntos no assentamento Carlos Marighella, a cerca de $12 \mathrm{~km}$ da região central de Santa Maria. Já Igor mora no distrito Arroio Grande, distante $25 \mathrm{~km}$ do centro da cidade.

16 Ressaltamos que Pedro Henrique e Raimundo, dois entrevistados na pesquisa, durante nosso um ano de acompanhamento, modificaram alguns aspectos na assistência televisiva. Não assistem mais ao seu antigo programa favorito, o Pânico na TV, por exemplo. Pedro Henrique afirma que perdeu o interesse após entrar na faculdade e agora mantém uma postura crítica: "deixei de assistir porque só fazem chacota das pessoas, não é legal." 
Para a seleção, o critério foi a assistência frequente da televisão e do Jornal Nacional. Essa escolha foi baseada na experiência de Morley (2001), que realizou um estudo etnográfico de recepção do NationWide em ambientes artificiais e com pessoas que não necessariamente assistiam ao programa. Seu método foi revisado, $\mathrm{e}$ ele afirmou que a assistência em ambientes cotidianos e com receptores familiarizados com os programas é o melhor caminho para a recepção. Dessa forma, realizamos entrevistas semiestruturadas e a entrevista biográfica com os jovens selecionados, sendo que a etnografia foi realizada com todos, salvo com Lúcia ${ }^{17}$, que atualmente não reside em Santa Maria.

Os jovens, que têm idades de 17 e 18 anos, declaram-se estudantes, feirantes e/ou agricultores. A maioria da amostra é composta por homens. A dificuldade em encontrar mulheres jovens que morem no campo corrobora pesquisas que demonstram a masculinização do meio rural (Carneiro, 2005; Weisheimer, 2009). Notou-se que o casamento e o nascimento de um filho, como foi o caso encontrado no assentamento Carlos Marighella, delimita o fim da juventude, já que jovens casados e com filhos não eram indicados quando se questionava para a comunidade em quais famílias se poderia encontrar jovens. Nossa pesquisa objetivou compreender as formações distintas que influenciam na construção de suas leituras, bem como analisar as leituras das desigualdades sociais do campo que os jovens têm da mídia referenciada.

Dividimos nossa investigação com os jovens em três momentos, sendo eles a pesquisa da história de vida, a assistência do telejornal em suas residências, com ou sem seus familiares, adequando-se ao ritmo cotidiano dos jovens, e, por fim, a assistência de vídeos selecionados sobre temáticas relacionadas às desigualdades

17 Nome fictício. 
sociais e ruralidades, tema em que se encaixam as notícias sobre os movimentos sociais. Não houve sequência determinada, realizamos as entrevistas de acordo com a disponibilidade dos jovens e a necessidade da investigação. Os momentos de entrevistas se mesclaram ao de observação participante, ocorrendo, também, as conversas informais com os pais e os moradores mais antigos das localidades.

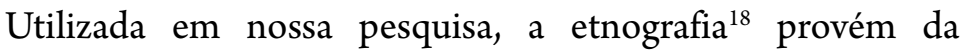
Antropologia e assumiu importância expressiva ao longo dos anos 1980, adquirindo nova abordagem ao ser utilizada em estudos de gênero ou em meios urbanos. A etnografia passou também a ser construída para sua utilização nos estudos da mídia, empregada na recepção especialmente como "uma forma de interpretação que pretende aguçar nossa sensibilidade para os detalhes de como as pessoas lidam com a televisão em seus cotidianos [tradução nossa]" (ANG, 1991 apud DROTNER, 1994, p.395).

O cotidiano é a força motriz para a etnografia, já que possibilita fornecer detalhes e construir subjetividades e características da ordem do abstrato. $\mathrm{O}$ ato de assistir à televisão, que tem fortes vínculos no dia a dia e por várias vezes está incluído nas atividades rotineiras das pessoas, está relacionado ao cotidiano: “Televisão é a vida cotidiana. Para estudar um, temos que estudar ao mesmo tempo o outro [tradução nossa]” (SILVERSTONE, 1989, apud, DROTNER, 1994, p.345).

18 Em nossa pesquisa, utilizamos a etnografia crítica da recepção. Denominamos o método como crítico, porque ele dá atenção, como aponta Ronsini (2007), também à reprodução social, e não somente à criatividade e à resistência dos receptores. A mesma autora, em seu livro "Mercadores de sentido: Consumo de mídia e identidades juvenis" afirma que esse pensamento é construído a partir da "apreensão do sentido possível que os atores sociais dão às práticas sociais e culturais produzidas na relação com os meios de comunicação tecnológicos.” (RONSINI, 2007, p.77) 
Através do contato estabelecido com esses jovens e suas famílias, assim como acompanhando a assistência da televisão, observando a lida no campo e o estar em casa, buscamos entender as particularidades e vivências de cada indivíduo, interpretando a partir disso o significado da mídia para os receptores:

El hogar o la família, insertos en un ambiente social y cultural más amplio, proporcionan, con sus pautas de interacción cotidiana, con sus propios sistemas internos de relaciones, y su própia cultura de legitimación y de formación de la identidade, un laboratorio para la investigación naturalista del consumo y la producción de sentido. (MORLEY, 1992, p. 263)

Nas análises de recepção, a etnografia obteve importância especialmente por relativizar as assertivas da crítica ideológica, na qual houve a "desmitificação" do poder dos meios sobre a audiência. No entanto, Escosteguy (2001, p.42-3) pondera essa afirmativa, pois crê que:

Ao operar no ponto de encontro onde determinadas condições sociais transformam-se em condições especificamente vividas, trabalha-se por dentro de fronteiras. Nesse estreito espaço, de difícil acesso, corre-se o risco permanente de celebrar as resistências ao reconhecer que as audiências respondem ativamente às formas culturais massivas, principalmente, se for levado em consideração o trabalho anteriormente executado de "desmistificar, denunciar e condenar" o poder dos meios sobre a audiência.

Dessa forma, consideramos que o receptor estabelece uma relação ativa com os textos midiáticos, mas não buscamos uma 
vinculação esperançosa de autonomia, ou uma euforia com a vitalidade das audiências, para citar Escosteguy (2001, p.44). Nesse caso haveria uma submissão das relações de poder, o que não concordamos. Assim, falar em mediação e etnografia não significa entrar diretamente no debate da recepção ativa.

Ao total, foram realizados trinta encontros com os quatro jovens, sendo alguns com suas famílias, outros somente com o entrevistado. As entrevistas foram realizadas em suas residências, algumas na varanda, outras na sala ou na cozinha. Seguidamente os pais apareciam e ouviam alguns minutos da entrevista, mas não interferiram efetivamente.

Acompanhamos as feiras livres, aos sábados pela manhã, no Centro de Referência de Economia Solidária Dom Ivo Lorscheiter. Lá era o local onde a família de Igor comercializava seus produtos. Inicialmente minha presença parecia ser um incômodo, especialmente para os jovens. Os pais tinham mais iniciativa para falar comigo. Após algumas semanas de observação participante, as conversas tornaram-se corriqueiras, especialmente após minha apresentação aos curiosos, como os amigos das famílias e os clientes mais assíduos. Essas atividades ocorreram antes das entrevistas e da assistência ao telejornal nas residências, mas continuaram de forma mais esparsa após os encontros em suas residências. No assentamento, enquanto esperávamos os jovens chegarem do trabalho ou da escola, houve uma aproximação do cotidiano familiar, além da possibilidade de questionar os pais sobre a história da família e do assentamento.

Para trabalhar com os jovens, também selecionamos algumas matérias relacionadas às desigualdades sociais do campo. A seleção desse material visou contemplar algumas categorias trabalhadas na pesquisa, sendo elas: agronegócio, agricultura familiar, homem do campo, transgenia e movimentos sociais. Esses vídeos foram assistidos 
em suas residências, em horário acordado entre pesquisador e entrevistado.

\section{Resultados e discussão}

O meio rural foi o principal carro chefe do projeto desenvolvimentista do país, gozando de especial atenção até o início do século $\mathrm{XX}$, quando da ascensão da urbanização e da industrialização. Prova disso é que, nos séculos anteriores, as casas do campo eram mais bem cuidadas que as da cidade, o que representa uma forma de distinção e status. No decorrer do século XX, os parâmetros mudaram. $\mathrm{O}$ centro de desenvolvimento focou-se no meio urbano e o campo foi relegado à sua função extrativista e agrícola. O meio rural como modo de vida (Wanderley, 1999) passa a entrar em crise. Às representações do meio rural como um lugar tranquilo e sossegado (Williams, 1989), somam-se aquelas do atraso.

Hoje, pensar nas ruralidades pode significar sossego para muitas pessoas. No entanto, há outras significações para os trabalhadores do campo. Para os jovens da amostra, falar sobre o rural é versar sobre o trabalho pesado e que, por vezes, exercem desde tenra idade; é ver o trabalhador como um guerreiro, mas também como um sofredor; é afirmar que são diferentes em relação ao jovem que cresceu na cidade, ao mesmo tempo em que não percebem diferenças gritantes entre o meio urbano e o rural, especialmente porque sua conjuntura possibilita transpassar as fronteiras culturais entre o campo e a cidade. Além disso, pensar no meio rural, para esses jovens, é falar sobre planos para a propriedade ou, de uma forma saudosista, contar como era a vida com as famílias que deixaram "para fora" antes de se mudarem para o meio urbano em busca de realização pessoal, educação e emprego. As representações sobre o meio rural são diversas, bem como os modos de vivenciar esse espaço. 
O mundo rural não gera notícias recorrentes no Jornal Nacional. A distância das rotinas jornalísticas e do próprio mundo de vida dos profissionais da informação colabora para que as matérias priorizem o meio urbano. Devemos lembrar, ainda, que de acordo com o último censo, a população brasileira é mais urbanizada que há 10 anos. Já em 2000, 81\% dos brasileiros viviam em áreas urbanas; e, em 2010, esse número aumentou para $84 \%$. De acordo com observação do telejornal realizada pela pesquisadora durante os meses de outubro de 2011 a fevereiro de 2012, as matérias sobre ruralidades versaram, em sua maioria, sobre economia agrícola, em especial àquela relacionada ao mercado exportador. Há matérias, também, sobre secas e enchentes. $\mathrm{O}$ mundo rural referindo-se a um espaço de vida e de reprodutividade social é pouco mostrado no Jornal Nacional.

Fernandes (2010, p.189), ao falar sobre a mídia brasileira - e ele engloba a Rede Globo, o jornal Folha de São Paulo e a revista Veja -, afirma que tenta-se impedir que a realidade do campo brasileiro apareça como de fato é: uma das estruturas fundiárias mais concentradas do mundo e ainda em processo de intensificação dessa desigualdade rural." Para o autor, a mídia colabora mostrando os conflitos, mas não explica o motivo de existirem, focando os problemas nos movimentos camponeses, como o MST.

Para Campos (2011, p.109), os grupos de comunicação difundiram a concepção de que a produção de alimentos em grande escala é sinônimo de agronegócio. A generalização do termo faz considerar as iniciativas produtivas agroindustriais ou agropecuárias como agronegócio, quando podem ser ao contrário. Os agricultores que consomem insumos e têm maquinários pesados em suas propriedades não necessariamente estão alinhados a esse modelo de desenvolvimento rural.

O uso de agrotóxicos continua sendo um assunto polêmico para os jovens. Os pequenos agricultores buscaram, ao longo dos anos, 
uma proposta de diferenciação com alimentos orgânicos e agroecológicos. Dessa forma, a produção generalizada com agrotóxicos é rechaçada. Os jovens, ao assistirem às notícias sobre a utilização do agrotóxico, referem-se ao produto como um "veneno". Percebe-se que o agrotóxico não é "somente" um elemento químico. Para os jovens, a opinião sobre os agrotóxicos se amparam na ideologia fornecida pelos movimentos sociais. Outro jovem destaca que os produtores que desejam parar de utilizar o produto terão dificuldades para trabalhar com a commodity, pois as sementes já estão acostumadas: "como é que agora eles vão fazer para poder segurar a produção sem esse veneno? Com certeza vai dar muito mais trabalho para eles."

A relação do agrotóxico com a saúde também é lembrada. Um rapaz questiona os motivos que fizeram com que o produto fosse proibido nos Estados Unidos, como foi mostrado em uma reportagem do Jornal Nacional: "será que pra lá (Estados Unidos) não está fazendo mal para que eles retirem (de circulação)?” Por anos a família do jovem Igor trabalhou com plantação de fumo, como diversas outras pequenas propriedades na Quarta Colônia ${ }^{19}$. Essa produção é conhecida historicamente por sua dependência de agrotóxicos que, por vezes, acabam afetando a saúde dos agricultores. Esse frequente uso causou problemas de saúde em seu pai, e a mudança para a hortifruticultura foi essencial para a melhora da sua qualidade de vida. Sua mãe relatou que se tivessem continuado com a monocultura do fumo, ela teme que seu marido já estivesse morto. A partir da influência familiar, além do conhecimento adquirido nas oficinas de capacitação do projeto Cooesperança/Esperança, Igor tem contato com ideias fortemente contrárias ao uso de agrotóxicos e também à transgenia vegetal.

19 A Quarta Colônia Imperial de Imigração Italiana foi criada em 1877, no Rio Grande do Sul. 
Os jovens leem o Jornal Nacional a partir de seu cotidiano como pequenos agricultores. Para Pedro Henrique, as diferenças se fazem visíveis entre a sua propriedade e aquela que vê nas matérias sobre ruralidades: "faz questão de mostrar o tratorzinho" ou "falou que tem 160 trabalhadores fixos nessa propriedade, imagina." No assentamento, além de não existir mão de obra fixa contratada, o pai de Pedro Henrique trabalha com arado de tração animal, o que é considerado algo penoso e em desuso até mesmo por outros pequenos agricultores. A mecanização no assentamento Carlos Marighella é ínfima.

Ao assistirem a uma matéria sobre os transtornos que a transposição do Rio São Francisco estavam causando às famílias de pequenos agricultores no nordeste brasileiro, Lúcia diz que esses se encontravam "abandonados e piores do que já estavam", ou seja, a condição dos agricultores anteriormente era ruim e, com os transtornos, piorou. Aqui, éimportante ressaltar a categoria de sociabilidade, já que a moça deixou a zona rural, pois a família enfrentava problemas financeiros, principalmente porque seu núcleo familiar era grande e não conseguia cultivar todos os hectares de terra da propriedade que detinha. A situação da família de Lúcia é apontada por Raimundo: "a família dela enfrentava dificuldades, eram em número maior. Foi a única saída [ela sair do meio rural]”. Sobre a matéria do Rio São Francisco, Lúcia complementa, ao afirmar que a população das cercanias aparece como abandonada, que ela fica com a "a sensação de total desleixo do próprio governo."

Igor pensa diferente, pois acredita que os agricultores da matéria que tiveram suas casas danificadas com rachaduras causadas pelas explosões nas construções ganharam indenizações para deixar suas casas e já poderiam ter saído de suas propriedades. 
Os agricultores não saíram, porque não quiseram. Eles (o governo) estão dando indenizações, estão dando tudo para sair. O problema não é do governo, é dos moradores. (Igor, 17 anos, Grupo Terra Viva)

Os agricultores, no período das secas foram buscar emprego nas obras, mas não encontrarem emprego nas construtoras que estão trabalhando na transposição. Para Lúcia, isso mostra claramente a desigualdade social que existe no país. A promessa de progresso que a transposição traria, seja através da irrigação, seja por meio das vagas nas obras, ficou, para a moça, não é uma realidade, também porque as obras estão paradas em diversos lugares. Lúcia afirma:

Os grandes dão pouca ou quase nenhuma importância à sociedade da classe baixa, e que onde poderia dar mais renda e gerar mais empregos foi apenas ilusão para aquele povo. (Lúcia, 18 anos, assentamento Carlos Marighella)

Todos os jovens da amostra garantem que no Jornal Nacional são veiculadas mais notícias sobre agronegócio do que são apresentadas matérias relacionadas à agricultura familiar. Um dos motivos citados pelos jovens é que "a agricultura familiar não é uma coisa que dê muito dinheiro". Outro jovem aponta que "nunca falam do homem do campo". Um filho de assentado conta que o Jornal Nacional não mostra o pequeno produtor, mas sim aquele que já está estruturado

$\mathrm{O}$ pequeno agricultor, com uma hortinha de 50 por 30, com um canteiro de alface, um de cenoura, um de beterraba, não vai ter, não vai mostrar isso. Gostaria que mostrassem no Jornal Nacional, mas 
não vão. (Pedro Henrique, 17 anos, assentamento Carlos Marighella)

Para os jovens, o telejornal mostra o homem do campo como um sofredor, seja quando está em extrema seca ou quando sofreu com as enchentes. Guerreiro ou alguém que venceu as intempéries climáticas: essas são algumas características que os jovens dão para o homem do campo. A identidade social desse morador é ser um trabalhador do campo. O rural está ligado ao trabalho agrícola. Assim, os jovens concordam com a leitura do telejornal, a de que o homem do campo é alguém sofredor, "por causa de todo esse trabalho braçal que tem", diz Pedro Henrique. Raimundo também salienta o lado sofrido do homem do campo no Jornal Nacional, pois, para ele, o morador do campo aparece mais na época de apelos climáticos.

Quando aparece ali (no Jornal Nacional), aparece quando a pessoa perde tudo. Nunca ouvi na vida dizer: "Ah! O agricultor está bem de vida porque deu muito lucro na plantação." (Raimundo, 18 anos, assentamento Carlos Marighella)

Igor aponta outro lado. De acordo com ele, o Jornal Nacional prioriza os aspectos positivos do meio rural, não destacando as dificuldades do campo. O jovem cita o exemplo de uma matéria que mostrava a história de vida de uma agricultora familiar que tinha transformado sua vida.

Ela saiu, estava trabalhando numa feira comum, como a minha mãe, que saiu daqui e foi trabalhar numa feira grande. Ela saiu de um agronegócio pequeno que ganhava pouco para ganhar bastante. Como vou dizer assim, ganhava, em dinheiro, duzentos reais e foi lá para ganhar mil ou mil e 
pouco, aí ela se desenvolveu, ela foi crescendo mais, tendo mais coisas, entendeu? (Igor, 17 anos, Grupo Terra Viva)

Igor traz o exemplo do telejornal para sua vida pessoal. Sua mãe era empregada doméstica e seu pai trabalhava para uma empresa fumageira. Hoje eles trabalham como feirantes e são reconhecidos, pois trabalham na maior feira de Santa Maria. Para ele, a identificação com a matéria está relacionada com a mudança de vida positiva da família.

\section{O MST e a reforma agrária}

Mais de uma vez, em distintas perguntas, o assunto mídia e MST surgiu nas respostas, em especial com os jovens do assentamento Carlos Marighella. Eles se empolgavam durante suas argumentações, como se esse fosse, também, um momento de direito de resposta. Especialmente aqueles que tinham esse comportamento eram os jovens que haviam vivenciado de forma mais forte o cotidiano de ação do MST, como Pedro Henrique e Lúcia, que viveram respectivamente, por quatro anos corridos e dois anos, com períodos na cidade, em acampamentos. São os jovens, também, que são filhos de atuais ou antigos dirigentes do MST.

De acordo com Fernandes (2010, p. 179), a luta pela terra é um luta territorial e de família, "já que envolve o conjunto de seus membros em diversas atividades." Por mais que somente um dos membros esteja envolvido diretamente com os acampamentos ou ocupações, "a família camponesa toda se envolve na mobilização pela terra, cuidando de várias outras necessidades básicas."

O envolvimento de somente um membro familiar nos acampamentos é o caso da família de Raimundo. Embora isso tenha ocorrido, ele tem uma postura firma em relação às ocupações, o que lhe garante uma leitura de resistência, pois diz que o Jornal 
Nacional mostra os militantes do MST como "pessoas violentas. Isso que eles mostram. Pessoas que invadem tudo quanto é coisa." Não obstante ele tenha algumas críticas internas à política da época do acampamento e ao abandono do movimento social em relação ao assentamento, especialmente após a dissolução da cooperativa que mantinham, Raimundo acredita que o Jornal Nacional deveria mostrar outro lado do MST

Tinha que ter mais informação do que é que é Sem Terra. Eles falam muita coisa dos Sem Terra, não é pouco não. Chamando de ladrão.. esse tipo de coisa. Para falar dos Sem Terra tem que ter mais informação, do que só falar mal. Eu nunca ouvi falar bem dos Sem Terra na TV. Isso eu nunca vi. (Raimundo, 18 anos, assentamento Carlos Marighella)

A crítica dos jovens é que os militantes do MST aparecem como "baderneiros, bagunceiros", dando "a impressão que vão destruir alguma coisa, que vão chegar ali quebrando tudo." Pedro Henrique ressalta que essa é a impressão que o telespectador tem no final da matéria, pois a construção da notícia, ao seu ver, tendencia a notícia à desordem, à violência e à destruição. Para Lúcia, que também tem uma leitura resistente nessa questão, as notícias sobre as manifestações não problematizam o motivo da existência do movimento social, ou seja, a reforma agrária.

Quando estão noticiando sobre o MST, foi sempre quebrando alguma coisa, destruindo alguma coisa ou brigando por alguma coisa. Eu sempre vi isso no Jornal Nacional. No contexto bem em si não é tão mostrado o porquê daquela reforma 
agrária. Mais é mostrado o que eles estão fazendo naquele momento sem ter um antes ou em ter um depois. (Lúcia, 18 anos, assentamento Carlos Marighella)

Igor, que não é ligado ao processo da reforma agrária, afirma que o MST aparece no Jornal Nacional sempre de uma forma violenta, especialmente em suas manifestações. O jovem confirma que não tem nada contra a reforma agrária, mas não é a favor dos métodos do movimento social. Em conversas informais, Igor destaca o medo que tem de sua propriedade, que tem sete hectares, ser visada pelo MST para suas manifestações. Ele afirma que "o MST, ele gosta de caminhar (em referência às marchas). Por que a Dilma não pega um pedaço de terra lá na Amazônia e dá pra eles?"

Querem aumento tudo bem, mas para que fazer toda a destruição que eles fazem em lavouras, tomar lavouras, destruir cercas, fazer tiroteio como aquela vez, quando não sei quantos morreram lá com o tiroteio com a polícia? (Igor, 17 anos, Grupo Terra Viva)

Através da análise dos dados da amostra, percebemos que os jovens da amostra que são filhos de assentados da reforma agrária, ou seja, Pedro Henrique, Lúcia e Raimundo, têm, a partir de suas vivências, tanto no movimento social, quanto na cotidianidade familiar, uma criticidade em relação ao $\mathrm{JN}$ no que se refere à representação do movimento social em suas matérias. O jovem Igor, embora faça parte de um ambiente familiar a favor da reforma agrária e que, por vezes, conviveu com assentados no Feirão Colonial e no projeto Cooesperança/ Esperança, acaba tendo uma leitura contrária ao MST, baseadas especialmente na codificação apresentada pelo Jornal Nacional. 


\section{A pobreza}

Em nosso trabalho, não tratamos a pobreza como se sua existência fosse natural em nossa sociedade. Para nós, as desigualdades são socialmente construídas. Os jovens da nossa amostra são pertencentes à classe popular ${ }^{20}$. Embora sejam proprietários de terra, são pequenos produtores. Produzem hortifruticultura, têm pequenos animais, alguns estão, com a ajuda de programas federais ou municipais, começando a escavação de micro açudes para a produção de peixes. Contudo, as famílias fazem parte da massa trabalhadora agrícola que não emprega mão de obra assalariada e que envolve o âmbito familiar em sua administração e trabalho cotidiano. $\mathrm{O}$ auxílio à produção agrícola de alguns membros da família podem não ser, também, remunerados. ${ }^{21}$

A resistência da representação da pobreza no Jornal Nacional é majoritária em nossa amostra. Todos os jovens discordam da maneira como o pobre é mostrado no telejornal. De maneira geral, os jovens afirmam que a miserabilidade e a vulnerabilidade dessa classe são as principais características apresentadas pela classe popular no Jornal Nacional. Para Lúcia, o telejornal apresenta a pobreza como algo negativo, o que ela discorda

20 Como lembra Hall (2006, p.245), o termo "popular" guarda relações muito complexas com o termo "classe". Hall (2006, p.241) tem como definição do termo popular "as formas e atividades cujas raízes se situam nas condições sociais e materiais de classes específicas; que estiveram incorporadas nas tradições e práticas populares”. A sua definição do popular está em relação contínua com as classes dominantes, seja de antagonismo, influência ou relacionamento, mas não existem "'culturas" inteiramente isoladas e paradigmaticamente fixadas, numa relação de determinismo histórico, a classes "inteiras" - embora existam formações culturais de classe bem distintas e variáveis.” (HALL, 2006, p.245)

21 Quadros, Waldir; Maia, Alexandre. Estrutura Sócio-Econômica do Brasil. Revista Economia Contemporânea, Rio de Janeiro, v. 14, n. 3, p. 443-468, set./dez. 2010 
É mais ou menos assim: ser pobre não é defeito. $\mathrm{Eu}$ acho que eu também sou pobre e não me arrumo mal assim. Ser pobre não é defeito, acho que não tem muita diferença. Só um pouco de menos luxo... um pouco menos de luxo. Não tem muita diferença. (Lúcia, 18 anos, assentamento Carlos Marighella)

Os jovens propõem que o telejornal mostre outro lado da vida das classes populares. Uma classe mais festiva, que foque mais no em seu cotidiano: "Ele vai para o trabalho, foi cansativo, voltou pra casa, vai tomar o chimarrão dele, vai conversar com a mulher dele. Não é totalmente bom ou totalmente ruim, tem um meio termo."

Raimundo, mesmo sendo filho de assentados, não é envolvido com o MST. Muito menos gosta de política. No entanto, sente em seu cotidiano as diferenças de classe. Para ele, pobres e ricos vivem em situação antagônica. É evidente a apropriação do conceito de identidade de classe através de vivências de seus pais, em especial no mundo do trabalho, em padarias, na fábrica e em obras de construção civil. O jovem citou o exemplo do pai de seu de colega de escola que trabalhou 15 anos em uma empresa e foi demitido. Para o jovem, isso causa grande revolta:

Todo rico que começa a enriquecer, enriquece em cima de pobres. Os ricos não valorizam os pobres. Eles fazem as pessoas trabalhar, trabalhar, trabalhar, e quando estão bem, mandam eles embora. Ali no Distrito Industrial tem vários exemplos. O pai trabalha ali e conhece bem. Se as pessoas vão procurar emprego aqui e não dão, vão encontrar aonde? (Raimundo, 18 anos, assentamento Carlos Marighella) 
Igor, ao contrário dos outros, tem uma visão distante da desigualdade social, uma vez que diz não percebê-la no seu dia a dia. Afirma ter realizado um trabalho para o colégio sobre a temática, e que encontrou diversos sites sobre o assunto na internet, mas que não sabe falar sobre o tema. No entanto, o jovem não nega a desigualdade, ele sabe que existe, percebe no seu cotidiano, mas não pensa sobre o assunto, não tem criticidade. Não faz, por exemplo, a inter-relação da realidade de pequenos agricultores com a dos latifundiários, bem como a realidade das concentrações urbanas abordadas em telejornais. Quando questionado sobre o que poderia ser realizado para diminuir a desigualdade social em nosso país, o jovem demonstra distância e pouca reflexão em sua resposta

Não sei. Não trabalho com vida social. Não sei, pior que não sei mesmo. Não presto atenção nisso aí, né. (Igor, 17 anos, Grupo Terra Viva)

\section{Alguns apontamentos}

Os entrevistados utilizados para construção deste artigo, Igor, Pedro Henrique, Lúcia e Raimundo, têm matrizes parecidas. Embora discordem em diversas situações, os jovens concordam que o desenvolvimento rural no país enfrenta problemas com o latifúndio e o uso de agrotóxicos. A mediação família e movimento social, permeadas pela classe social, são fundamentais para entender as leituras das representações midiáticas. As histórias de vida dos jovens ajudam a explicar a leitura da mídia realizada pelos jovens. Por vezes, suas famílias foram oprimidas pela dependência de empresas fumageiras, no caso de Igor, ou por realmente não terem acesso à terra, no caso dos jovens envolvidos com o MST. A opressão os acompanhou em suas vidas. 
De modo geral, os jovens idealizam o meio rural como um local pacífico e com qualidade de vida, apresentando como aspectos negativos a falta de transporte público e privado, bem como a falta de lazer, saúde, comunicação e educação. No entanto, percebemos que Igor (Ecosol) e Pedro Henrique (Carlos Marighella) têm projetos de vida que mesclam o meio rural e o urbano. São esses jovens que mais circulam entre os dois espaços - para estudo, trabalho e lazer - e fazem planos para suas vidas de modo que se interliguem o campo e a cidade, caracterizando o que Carneiro (2005) chama de novas fronteiras culturais rural-urbanas.

Os jovens da amostra estão inseridos no contexto das transformações que o país vive nos últimos tempos. Partícipes da nova classe média, as famílias dos jovens estão cada vez mais inseridas na sociedade de consumo. Essa inserção é conquistada a um alto custo, como extensas horas de trabalho, além de, por vezes, enfrentarem o preconceito de classe que diferencia na vida prática a classe média tradicional e a nova classe trabalhadora. A nova classe média da amostra é a favor da transferência de renda condicionada do governo federal, e a maioria dos jovens participa do programa Bolsa Família, tendo uma leitura de resistência sobre a codificação proposta pelo Jornal Nacional.

O momento do telejornal é de encontro familiar. Após um dia de trabalho e estudo, essa é a hora de reunião, de contar o que ocorreu na jornada. As intimidades, por vezes, competem com o volume do som da televisão. Se a história que o familiar tem a contar é mais interessante que a matéria do Jornal Nacional, os olhos se deslocam da televisão e acompanham a narrativa do momento, que é, dependendo da família, de confraternização. Independente disso, constatamos que o momento reúne famílias.

Percebemos que, ao contrário do rechaço maior que há em relação ao agrotóxico, as matérias sobre transgênicos apresentaram 
maior aceitação nos entrevistados. Leituras negociadas foram encontradas em Lúcia e em Raimundo, mas por motivos distintos. Lúcia destaca a produtividade do transgênico, enquanto Raimundo perde-se nas explicações, afirmando ser "coisa de Sem Terra" ser contra transgênico. Pedro Henrique e Igor, mais próximos de movimentos sociais, mantêm suas posições de resistência, sendo contrário à utilização do transgênico. Para os jovens que têm leituras resistentes, a agroecologia e o uso de defensivos naturais são o caminho para um desenvolvimento rural sustentável.

Outra temática que encontramos resistência é a representação da pobreza no JN. Os jovens discordam sobre como as classes populares estão representadas no telejornal, em especial sobre o enfoque na miserabilidade em que se encontram. Pedro Henrique, Raimundo e Igor confirmam que o Jornal Nacional prioriza o aspecto ruim de ter menos dinheiro e Lúcia acredita que ser pobre não é defeito.

Todos os jovens assentados são contrários às representações do MST no telejornal, sendo que Raimundo e Pedro Henrique criticaram alguns aspectos desse movimento social. Igor tem uma leitura alinhada à codificação dominante do Jornal Nacional, acreditando que os militantes fazem atos violentos e truculentos. Consideramos que ser jovem oriundo da agricultura familiar e relacionado a movimentos sociais, seja em prol da reforma agrária ou da economia solidária, não garante a criticidade do jovem em relação à mídia e nem seu envolvimento político em organizações civis. As leituras são decorrentes da mediação de classe, do histórico de vida, do envolvimento familiar no movimento social e da experiência escolar. Entre o ficar e o sair do meio rural, os jovens decidem-se entre a realização pessoal e a dependência financeira dos pais, que ainda ocorre em boa parte da amostra. 
A criticidade em relação aos meios de comunicação, que é bandeira dos movimentos sociais trabalhados, é um dos pontos a serem fortalecidos ou desenvolvidos nos discursos dos jovens. Pedro Henrique é o que apresenta maior criticidade, pois faz ponderações em relação aos telejornais e, de maneira geral, não confia nos meios de comunicação. $\mathrm{O}$ jovem diz que "por um lado talvez essas informações que eles passam não condizem com a verdade, né." Já Igor tem uma visão ingênua da televisão, pois confia nos programas televisivos e acredita que é um meio de comunicação para informar a população, "para a gente saber, né". Raimundo confia só em alguns programas de televisão, sendo que o Jornal Nacional é um deles. Lúcia diz que os telejornais são fontes de informação confiáveis, porque têm um grande público de assistência e, para ela, seria difícil enganar um grande público. Os jovens criticam algumas matérias, em especial suas representações, mas em geral confiam na qualidade técnica do telejornalismo, o que tem auxílio na credibilidade jornalística que o JN construiu nos últimos anos.

Para os jovens, embora assistam e tenham assistido durante muitos anos ao Jornal Nacional, eles são veementes em dizer que o programa não tem importância no cotidiano. Alguns apontam que há necessidade de se ter um filtro das informações para assistir ao Jornal Nacional, mas, em geral, afirmam que não faz diferença no dia a dia. Os jovens, no entanto, não têm uma variedade de acessos a informações jornalísticas que não sejam esse telejornal. Travancas (2007) afirma que para camadas populares a televisão é um veículo de informação fundamental. No caso, quanto menos condições sociais uma família tiver, mais difícil é o acesso à pluralidade de informações. Às vezes a única fonte de informação jornalística é o Jornal Nacional. Embora possam assistir a outros canais de televisão, como SBT, Band e Record, é válido 
problematizar aqui a diversidade editorial da chamada "grande mídia” brasileira. O quanto difere as notícias jornalísticas desses canais de televisão pública?

\section{Referências}

ANDERSON, Benedict. Comunidades imaginadas: reflexões sobre a origem e a difusão do nacionalismo. São Paulo: Companhia das Letras, 2008.

BOURDIEU, Pierre. La distinción - criterios y bases sociales del gusto. Madrid: Taurus, 1991.

CAMPOS, Christiane. A face feminina da pobreza em meio à riqueza do agronegócio: trabalho e pobreza das mulheres em territórios do agronegócio no Brasil: o caso de Cruz Alta-RS. Buenos Aires: CLACSO, 2011.

CARNEIRO, Maria José. Juventude Rural: Projetos e Valores. In: ABRAMO, Helena; Branco, Pedro. Retratos da juventude brasileira: análises de uma pesquisa nacional. Fundação Perseu Abramo: São Paulo, 2005, p.243-26.

DROTNER, Kirsten. Menos é mais: estudos etnográficos de mídia e seus limites. In: LOPES, Maria Immacolata V. de. Temas contemporâneos em comunicação. São Paulo: Edicon/Intercom, 1997.

ESCOSTEGUY, Ana Carolina D. Cartografias dos estudos culturais: uma versão latino-americana. ed. On-line. Belo Horizonte: Autêntica, 2001. (Coleção Estudos culturais; 8). Disponível em: $<$ http://identidadesculturas.files.wordpress.com/2011/05/ 
cartografias-dos-estudos-culturais-uma-versc3a3o-latino-americana. pdf $>$.

FERNANDES, Bernardo. Formação e territorialização do MST no Brasil. In: CARTER, Miguel (org.). Combatendo a desigualdade social - O MST e a reforma agrária no Brasil. São Paulo: Editora UNESP, 2010.

HALL, Stuart. Da diáspora - identidades e mediações culturais. Belo Horizonte: Editora UFMG, 2006.

MAIA, Aline. Televisão, telejornalismo e juventude: o que jovens da periferia pensam sobre o Jornal Nacional? Estudos em jornalismo e mídia. v.6, n. 2, p. 175 - 188 jul./dez. 2009.

MINAYO, M.C.S. O desafio do conhecimento. São Paulo: Hucitec. 1999. 269 p.

MORLEY, David. Depoimento de David Morley a Ana Carolina Escosteguy. In: Cartografias dos Estudos Culturais: uma versão latino-americana. Belo Horizonte: Autêntica, 2001. p.249-268.

QUADROS, Waldir; MAIA, Alexandre. Estrutura socioeconômica do Brasil. Revista Economia Contemporânea. Rio de Janeiro, v. 14, n. 3, p. 443-468, set./dez. 2010

RONSINI, Veneza. Mercadores de sentido: Consumo de mídia e identidades juvenis. Porto Alegre: Sulina, 2007.

TRAVANCAS, Isabel. Juventude e televisão. Rio de Janeiro: FGV, 2007. 
VIZEU, Alfredo. O telejornalismo como lugar de referência e a função pedagógica. Revista FAMECOS. Porto Alegre, n. 40, 2009.

WANDERLEY, Maria de Nazareth. O mundo rural como um espaço de vida: reflexões sobre a propriedade da terra, agricultura familiar e ruralidade. Porto Alegre: Editora da UFRGS, 2009.

WEISHEIMER, Nilson. A situação juvenil na agricultura familiar. 2009, 320 f. Tese (Doutorado em Sociologia) - Programa de Pós-Graduação em Sociologia da UFRGS. Porto Alegre: UFRGS, 2009. Disponível em: < http://www.lume.ufrgs.br/bitstream/handle $/ 10183 / 15908 / 000693991 . p d f$ ? sequence $=1>$

WILLYAMS, Raymond. Campo e a cidade na história e na literatura. Trad. por Paulo Henrique de Britto. São Paulo: Cia das Letras, 1989. 


\title{
A crônica como um espaço itinerante da cidade
}

\author{
Jeana Laura da Cunha Santos
}

\section{Introdução}

É no limiar entre dois tempos que duas experiências antagônicas, porém complementares, convivem lado a lado. Nestas zonas cinzentas, em que o novo não está completamente delineado e nem o passado é totalmente descartado que podemos depurar os sentidos e produzir quiçá uma reflexão teórica isenta de determinismos. Eis a dialética dos períodos de transição, onde o velho e o novo convivem lado a lado.

O presente trabalho procura tocar a beirada de dois tempos (a virada do século XIX para o XX) no espaço de um Rio de Janeiro constituído de passagens: entre o escravismo e a mão-deobra assalariada, entre a manufatura e o trabalho industrial, entre a Monarquia e a República, entre a escritura sacralizada do livro e a escritura mecanizada dos jornais.

Ao se atar estas pontas temporais, acaba-se por se debruçar também sobre o espaço em suas zonas fronteiriças. Nada mais emblemático desta passagem do que a transposição da zona 
domesticada da casa para a zona ignóbil da rua. Ir para a rua nos começos do século XX no Rio de Janeiro era feito com um misto de medo e prazer, o que não era prerrogativa apenas da cidade brasileira, uma vez que Walter Benjamin (1994) também se debruçaria sobre o fenômeno na sua análise da ocupação das ruas de Paris, e da consolidação da flânerie como novo modelo do habitante da cidade, aproximando o tipo do jornalista que transforma os muros em escrivaninhas, as bancas de jornal em bibliotecas e os terraços, a sacada de onde observa o ambiente.

Domesticar a ameaça subscrita na cidade era o imperativo e isso fica evidente na construção de espaços intermediários (nem tão a casa e nem tão a rua) na arquitetura da cidade. Se em Paris as galerias (que Benjamin definiria como um mundo em miniatura, com seus caminhos cobertos de vidro e revestidos de mármore e por onde se estende os mais elegantes estabelecimentos comerciais) cumpriam essa função de apaziguar o medo da rua, não seria outro o propósito da varanda no contexto brasileiro, definida por Saint-Hilaire (apud DAMATTA, 1987, p.56), europeu que visitou o Brasil em 1816 e 1822, como uma galeria sustentada por colunas de madeira que se prolonga na frente da casa e onde a gente abastada contempla a rua ao abrigo da chuva e do sol.

A arquitetura do texto também sofreria modificações. Um gênero literário do século XIX, resgatado por Benjamin, é a "literatura panorâmica". Dentro deste gênero, havia os fascículos em formato de bolso chamados de "fisiologias", que se ocupavam da descrição de tipos humanos que circulavam nas feiras de Paris. Mais tarde, dedicar-se-iam à consagração da cidade, perfilando suas ruas, seus panoramas, tudo para tornar aprazível a ameaça do outro estranho e do espaço "estrangeiro" da rua.

E se em Paris eram os fisiologistas que adquiriam status, aqui no Brasil, a crônica surgiria para aplacar os sentidos e se configurar 
como uma escritura moderna, calcada no modelo de fragmentação que abandona a casa do livro para se sagrar no veículo móvel, urbano e volátil do jornal.

E é essa passagem que nos interessa. Traçar uma fisiologia da crônica nos assuntos que documenta, já que tem os olhos voltados para as mínimas histórias que se engendram na cidade, e também enquanto uma narrativa urbana que alegoriza na sua própria forma (fragmentada, efêmera, distraída) a experiência moderna do habitante da cidade. Ao dissecá-la, pensar também no papel destes primeiros escribas (os jornalistas) que abandonaram a casa segura, canônica, domesticada da palavra livresca para se aventurar, enquanto flâneurs, no olho da rua.

Habitar as ruas é, então, tarefa do jornalista. No Brasil, a crônica seria o gênero inaugurador que retrataria o fluxo de sujeitos e fatos pelas ruas da cidade. A crônica abandonaria a casa da palavra para se deixar ir, volúvel e volátil, para o coração das ruas.

\section{Eis a origem da crônica}

Analisar a crônica enquanto um texto produzido na e sobre a cidade em trânsito é vê-la como uma narrativa urbana dentro de uma antropologia que pensa o movimento. Porque a crônica conserva em si, desde o tempo de sua gênese até os dias de hoje, os resíduos produzidos pela cidade que se moderniza. A fragmentação do olhar do homem moderno, sua necessidade de adaptar-se à aceleração da vida na cidade é sentido pelo transeunte na multidão. Forja-se uma coletividade que habita as ruas. Habitar as ruas é, então, tarefa do cronista. Se o livro é a alegoria do interior burguês, o jornal representa o fluxo de sujeitos e fatos pelas ruas da cidade em movimento. A crônica media esses dois espaços, reproduzindo o retrato de um tempo em 
que havia uma propensão do olhar para se deslocar do mundo fechado dos interiores burgueses para o mundo aberto das ruas em ebulição.

Escrita tipicamente brasileira, nela é possível detectar tanto na sua forma como nos assuntos que documenta "todo lo que en una ciudad puede ser visto flotando en su superfície” (DELGADO, 1999, p.26). Não é gratuito o fato de ter seus inícios em um Rio de Janeiro cujo traçado e formas de vida convergiam para o que se poderia definir como metrópole, em que pesem as contradições inerentes de um tempo marcado pelos descompassos políticos e sociais da virada do século XIX para o XX.

Traduzindo em si tais traços ambíguos dos momentos de transição, a crônica nasce imprecisa, volúvel, descartável, sem marco inicial, como ironizaria Machado de Assis, um de seus fiéis representantes na literatura nacional e um de seus grandes entusiastas:

Não posso dizer positivamente em que ano nasceu a crônica; mas há toda a probabilidade de crer que é coletânea das primeiras duas vizinhas. Essas vizinhas, entre o jantar e a merenda, sentaram-se à porta para debicar os sucessos do dia. Provavelmente começaram a lastimar-se do calor. Uma dizia que não pudera comer ao jantar, outra que tinha a camisa mais ensopada do que as ervas que comera. Passar das ervas às plantações do morador fronteiro, e logo às tropelias amatórias do dito morador, e ao resto, era a coisa mais fácil, natural e possível do mundo. Eis a origem da crônica. (FOLHA DE S. PAULO, 1994, p.13-15).

Marlyse Meyer (apud CANDIDO, 1992, p.93-113) ressalta a dificuldade de se precisar com exatidão o nascimento do gênero. Segundo ela, nos começos do século XIX, le feuilleton designava o rodapé da primeira página dos jornais, espaço destinado ao 
entretenimento e onde valia tudo: contar piadas, propor charadas, oferecer receitas... De espaço vale-tudo, passa, em finais de 1830, a publicar ficção em fatias, com enorme retorno financeiro para os jornais. Mas é no corpo interno do Jornal do Commércio, sob a rubrica de Variedade, que, em fins de 1830, passa-se a publicar aquilo que viria a dar na crônica: conteúdos variados, matérias traduzidas, resenhas, ficções curtas, poesias, lista de traduções etc. O romance-folhetim, "avô de todas as nossas novelas", continuaria a ocupar o rodapé da página um. Em ambos os casos, folhetim-variedade ou romance-folhetim, alguns escritores, ao terem que traduzir ou escrever a toque de caixa pelo novo imperativo da velocidade do meio jornal, transpuseram esse modo de escrita para o seu posterior texto de ficção, o que comprova a simbiose estabelecida nesse momento de transição, via folhetim ou crônica, entre a literatura e o jornalismo.

Segundo a autora, ao adotar um tom ligeiro, miúdo, da fala cotidiana, a crônica passou a incorporar também um toque de humor, libertando-se, enfim, do folhetim e passando a ter vida própria, sendo esse um momento crucial para o seu amadurecimento.

A crônica foi, então, a forma oportuna de passagem entre a literatura e o jornalismo, subscrevendo um novo estilo, contaminado pelo enquadramento fragmentário da diagramação das folhas, pela pressão dos horários, pela velocidade da própria movimentação das rotativas e em sincronia com os assuntos gerados pelas ruas de uma cidade cujo protagonista era sem dúvida o movimento.

A crônica alegoriza assim o espaço itinerante, em movimento, subscrito nas cidades. Ao revisar topografias sobre a mobilidade nas cidades, Delgado alude aos espaços transversais, cuja função seria o de transpassar, cruzar, intersectar outros territórios. "En los espacios transversales toda acción se plantearía como un a través de. No es que en ellos se produzca una travesía, sino que son la travesía en 
si, cualquier travesía. No son nada que no sea un irrumpir, interrumpir y disolverse luego" (DELGADO, 1999, p.36).

Nada mais condizente à crônica do que a ideia de sua dissolução instantânea. Se os livros almejam a permanência, a fixação e o espaço privado da casa, a crônica consolida a supremacia do que é volátil, móvel e público, tal qual a marcha incessante dos pedestres de uma cidade. Além disso, ela própria é esse espaço itinerante, uma vez que liga a literatura central, canônica, à periferia marginal do jornal, metaforizando assim a definição da Escola de Chicago, recuperada por Delgado, sobre zona de transição, que nada mais é do que um passeio que liga o distrito central às zonas habitacionais periféricas. Por essa via de passagem, por esse "espaço-trânsito", parafraseando ainda Delgado a respeito da rua, transitam tipos que fortuitamente se reconhecem e se estranham e que seguem sua marcha sem se fixar. As notícias que nela se imprimem também não têm a pretensão da durabilidade, sendo descartadas por uma outra novidade a cada nova edição do jornal, daí a constatação permanente de uma transitoriedade que permeia o tempo e contamina seres e coisas. O tempo do jornal, esvaziado da eternidade que era conferida ao livro, é cada vez mais constituído de intensidades luminosas, mas que já nascem com a marca do que não dura.

Esse sentido fora captado por Machado de Assis na pergunta de caráter benjaminiano que lançou em crônica de 1886: "Mas o que é que dura neste mundo, a não ser as Pirâmides do Egito e a boa fé da minha comadre?" (PAIVA DE LUCA, 1998, p.334-335). A crônica versa sobre os desfalques que começam a se alastrar pela cidade do Rio de Janeiro, um assunto que não duraria muito, talvez "algumas horas, dois ou três dias", "mas o que é que dura mesmo neste mundo?” - pergunta o narrador. De fato, num mundo recheado de informações cotidianas, nada mais é durável para além de alguns instantes. E, embora tal fragmento, em seu questionamento filosófico, 
pareça queixar-se da transitoriedade de tudo, a ironia contida nele revela o contrário. $\mathrm{O}$ cronista parece estar à vontade, rindo-se da caducidade que paira sobre a época. Mas, enquanto ri, denuncia-a. Transita, como sempre, tal qual o personagem Brás Cubas, de Memórias Póstumas, "entre a pena da galhofa e a tinta da melancolia" (ASSIS, 1992). Nesse lugar de passagem, esvazia a imortalidade do tempo para apostar na sua repetição e decadência.

A mesma transitoriedade está presente no jornal. Osman Lins tem uma metáfora interessante para denotar a passagem do livro ao jornal. Compara-os a duas moradas distintas. A primeira procura "isolar do século as coisas permanentes ou aquelas para as quais desejaria o homem uma vida que ultrapasse a duração da sua" (LINS, 1974, p.125). Para isso, interpõe entre a habitação e o leito da rua degraus, erige muros e jardins nos palácios, eleva o pórtico e o altar-mor das igrejas. Esses teriam a mesma função que tem nos livros a encadernação em couro com guarnições de ferro, de ouro, de prata, de marfim, com fechaduras e correntes que assegurariam a condição de um espaço privilegiado, fora da ação do tempo. Sem falar na "gradação quase ritualística" que as várias sedimentações de um livro impõem: a capa, a guarda branca, a falsa folha de rosto, a verdadeira folha de rosto... Já o periódico preocupa-se com o temporário, e o assunto de capa de qualquer jornal ou revista esforça-se para perseguir o já:

Assim é que o jornal, por sua natureza ligado ao dia a dia, expressão do fato em andamento ou apenas consumado e prestes a ser esquecido, substituído, dispensa toda espécie de separação entre o texto impresso e o mundo. Reflexo do transitório, ele mesmo exemplo das coisas que não permanecem, não tem integridade alguma a resguardar. Ligado 
estreitamente ao tempo, sobrevém para fugir, passar, ser esquecido (LINS, 1974, p.126).

Mas, paradoxalmente, esse corpo que nasceu para ser esquecido eterniza a experiência de ruptura que uma multidão urbana teve ao se desalojar da morada do livro. Uma morada que prometia a continuidade de uma tradição, embalada por ideais burgueses de distanciamento, individualidade e permanência. Uma morada cujo interior dificilmente comportaria aquela que Walter Benjamin (1994) chamaria de "massa". Desalojada de tal morada, o interesse dessa massa urbana encontraria respaldo no corpo similar ao seu do jornal. Entre o individual e o coletivo, entre a permanência e o que não dura, entre o que está distante e bem guardado e o que está próximo e enxovalhado, entre o que tem casa e o que habita as ruas, ambos (massa e jornal) inclinar-se-iam para os segundos elementos dessas dicotomias.

E como se viu, a crônica é esta zona de passagem. $\mathrm{O}$ cronista é o flâneur que habita/desabita a cidade ao percorrê-la a pé, atento ao ir e vir do fluxo humano e das informações. Ele se apropria não tanto da cidade em si, mas de suas zonas itinerantes, constituindo a metáfora eficaz do que Delgado pleiteia para o estudo da antropologia urbana quando diz que ela deveria se debruçar menos sobre a cidade e mais sobre os espaços usados transitoriamente, sejam públicos (ruas, vestíbulos, parques, metrô), sejam semipúblicos (cafés, bares, discotecas, superfícies comerciais).

Es ahí donde podemos ver producirse la epifanía de lo que se há definido como especificamente urbano: lo inopinado, lo imprevisto, lo sorprendente, lo oscilante... La urbanidade consiste en esa reunión de extraños, unidos por la evitación, el anonimato y otras películas protectoras, 
expuestos a la intempérie, y al mismo tiempo, a cubierto, camuflados, mimetizados, invisibles (DELGADO, 1999, p.33).

Neste sentido, o usuário do espaço urbano é quase sempre um transeunte, alguém que está ali apenas de passagem.

Uma embriaguez acomete aquele que longamente vagou sem rumo pelas ruas. A cada passo, o andar ganha uma potência crescente; sempre menor se torna a sedução das lojas, dos bistrôs, das mulheres sorridentes, e sempre mais irresistível o magnetismo da próxima esquina, de uma massa de folhas distantes, de um nome de rua (BENJAMIN, 1994, p.186).

A descrição acima cabe ao flâneur, tipo surgido na Paris do início do século XIX e analisado por Benjamin que o aproximaria do jornalista. "A base social da flânerie é o jornalismo. É como flâneur que o literato se dirige ao mercado para se vender" (BENJAMIN, 1994, p.225). Sua força de trabalho é o tempo que gasta na contemplação dos bulevares. As novas experiências na cidade são a sua matéria-prima. $\mathrm{O}$ espetáculo da cidade o inebria e converte-se em mercadoria para consumo desta massa através das páginas volantes do jornal,

O mundo urbano tem características e particularidades que se expressam no jornalismo. Quando Georg Simmel (1979) cita o anonimato, as relações transitórias e a superficialidade como aspectos dos indivíduos urbanos, não se pode deixar de associar essas características ao jornalista. $\mathrm{O}$ jornalista experimentará no seu cotidiano a cidade como espaço da diversidade, do cruzamento de mundos e "tribos" 
diferentes, desvendando territórios heterogêneos e construindo, assim, um mapa, para muitos habitantes, desconhecido. (TRAVANCAS, 2010, p.123).

Para João do Rio, talvez o primeiro jornalista da história brasileira porque ao contrário dos outros cronistas do seu tempo imergiu no bojo das ruas para extrair material para seus textos, o flâneur (também chamado por ele de "pedestre da poesia da observação") é um ingênuo porque, "conhecendo cada rua, cada beco, cada viela, sabendo-lhe um pedaço da história, (...), acaba com a vaga idéia de que todo o espetáculo da cidade foi feito especialmente para seu gozo próprio" (RIO, 2011, p.32). E completa: "Eu fui um pouco esse tipo complexo, e, talvez por isso, cada rua é para mim um ser vivo e imóvel” (RIO, 2011, p.33).

Se para Delgado (1999), os protagonistas da antropologia urbana não poderiam ser comunidades coerentes e homogêneas e sim os atores de uma alteridade que se generaliza (passantes a deriva estrangeiros, trabalhadores e moradores das vias públicas, dissimuladores natos, peregrinos eventuais, etc.), diríamos de João do Rio que fazia a seu modo uma antropologia da cidade. Nas suas crônicas de amor às ruas todo um documento emblemático destes tipos que transitam no seio de uma cidade que enquanto cresce se torna "arruada": o cigano, o trapeiro, o apanha-rótulos, o selista, o caçador, o ledor, o tatuador, o vendedor de orações, o mercador de livro, o pintor da cidade, o velho cocheiro... Exemplos do que João do Rio chamaria de "pequenas profissões ignoradas":

Oh! Essas pequenas profissões ignoradas, que são partes integrantes do mecanismo das grandes cidades!

O Rio pode conhecer muito bem a vida do burguês de Londres, as peças de Paris, a geografia da 
Manchúria e o patriotismo japonês. A apostar, porém, que não conhece nem a sua própria planta, nem a vida de toda essa sociedade, de todos esses meios estranhos e exóticos, de todas as profissões que constituem o progresso, a dor, a miséria da vasta Babel que se transforma. (RIO, 2011, p.60).

Tais tipos são como o cronista que extrai das ruas (e devolve a elas) o insumo de seu ofício. $\mathrm{O}$ ir e vir despretensioso dos passos do flâneur/cronista que vagueia pelos espaços em movimento da cidade imprime-se no modo como executa a crônica: pouca coisa sobrevive sob as ruínas produzidas por uma cidade que se industrializa. Sempre há uma novidade, uma nova moda, a disputar o olhar de quem vagueia desinteressado, seja ele cronista ou leitor. Não é à toa que Raul Antelo vê familiaridade entre a crônica e a modernidade justamente por ambas sucumbirem à moda:

Ambas são sensíveis à circunstância repentina, ao que surge sem regras e com urgência. Ambas, porém, correm o risco de anulação na moda, explosão do acontecimento que perde seu modo na medida em que acontece, passando a ser mera informação, copiada, reproduzida, gasta. (ANTELO, 1989, p.38).

Em que pese o caráter paradoxal da crônica que usa em sua estrutura e assuntos o movimento apenas para produzir inércia, ela documenta o instante pioneiro em que a utopia de imortalidade e centralidade do livro também não dava mais conta de uma massa urbana em profunda transformação. A crônica registra o momento em que o indivíduo abandona o lugar central da casa (seja ela a casa da palavra que é o livro ou a casa real) para aventurar-se, enquanto massa, no "olho da rua", representado aqui pelo jornal. E se "la antropología urbana debería presentarse entonces más bien como una 
antropologia de lo que define la urbanidad como forma de vida" (DELGADO, 1999, p.26), a crônica representa a cidade e suas ruas menos em seu traçado espacial e mais na alma que se desprega de seus transeuntes.

E “o que é a rua?”, perguntar-se-ia João do Rio que teria consultado vários dicionários na busca por uma definição. Para tais dicionários, a rua era "apenas um alinhado de fachadas por onde se anda nas povoações. Ora a rua é mais do que isso, a rua é um fator da vida nas cidades, a rua tem alma!" (RIO, 2011, p.29). "As ruas são a morada do coletivo", diria Benjamin (1994, p.194), para quem "a rua conduz o flanador a um tempo desaparecido" (1994, p.185), tempo da infância.

A crônica documenta, então, o significado e a essência da rua na modernidade. No descompasso das passadas do transeunte/ cronista moderno que, distraído, vive a dialética própria dos períodos de transição, a representação de uma antropologia urbana que pouco tem a ver com os centros fixos, domesticados e estáveis.

Si la antropologia urbana quiere serlo de veras, debe admitir que todos sus objetos potenciales están enredados en una tupida red de fluidos que se fusionan y licúan o que se fisionan y se escinden, un espacio de dispersiones, de las intermitências y de los encabalgamientos entre identidades. (DELGADO, 1999, p.45).

O mesmo caráter de dispersão e circulação encontra-se na crônica. Contra a rigidez e durabilidade da literatura canônica, debruça-se sobre o movimento e as histórias mínimas que se processam nas ruas da grande cidade. E, ao fazê-lo, perfaz um movimento similar ao que Rocha e Eckert reivindicam para a antropologia urbana: o deslocamento do "foco de análise da descrição realista da 
cidade na história para um conhecimento compreensivo da cidade segundo os acontecimentos anódinos que ocorrem no seu interior e a efervescência que rege a vida ordinária de seus habitantes" (ROCHA; ECKERT, 2005, p.95). Ou nas palavras do personagem Brás Cubas:

Quem não sabe que ao pé de cada bandeira grande, pública, ostensiva, há muitas vezes várias outras bandeiras modestamente particulares, que se hasteiam e flutuam à sombra daquela, e não poucas vezes lhe sobrevivem? Mal comparando, é como a arraia-miúda, que se acolhia à sombra do castelo feudal; caiu este e a arraia ficou. (MACHADO DE ASSIS, 1992, p.23).

Por sua natureza miúda, a crônica assume um lugar estratégico para a reflexão antropológica.

Nas grandes metrópoles, a vida humana torna-se objeto principal de estudo pelos "retalhos, os resíduos", "secundário ou excêntrico": a moda, o jogo, o colecionador, os dioramas, a prostituição, o flâneur, as passagens, o interior, as ruas, a fotografia, o réclame. (ROCHA; ECKERT, 2005, p.83, grifos do autor).

A crônica é, sem dúvida, um destes resíduos.

\section{Conclusão}

Neste artigo, procuramos derivar do residual da crônica um registro do instante pioneiro em que a experiência do urbano passou a ser tematizada e vivenciada pelo jornalista/habitante da 
cidade moderna. Para tanto, procuramos definir o gênero, buscando suas características e origens, muito embora a imprecisão e a indefinição - tanto no que diz respeito a seu nascimento quanto a sua forma - sejam suas marcas por excelência.

A partir da análise de algumas crônicas produzidas pelos primeiros jornalistas brasileiros, na virada do século XIX para o XX, especificamente no Rio de Janeiro - cidade que traduz todo o imaginário da época e que ditava modas e costumes - deriva-se uma experiência pioneira na relação com as ruas, seus modos de vivência e comportamentos urbanos, capaz de dialogar com a teoria produzida por Walter Benjamin no contexto europeu. Demonstramos que, na Paris do século XIX, já havia uma demanda por uma narrativa que perfilasse os transeuntes de uma cidade em vias de modernização e que aplacasse o medo de se ir às ruas e exaltasse o fascínio de aventurar-se na multidão. Adotamos aqui a perspectiva do filósofo alemão que consiste em tomar a realidade por algo descontínuo, misturando os tempos, entrelaçando as várias histórias, dissolvendo o centro, preferindo as bordas, as margens, os produtos menores.

A interface entre a Antropologia, a Comunicação e a Literatura enfatiza problemáticas também fronteiriças: a ocupação da cidade, o espaço intermediário das galerias, o texto intermediário entre o livro e o jornal (a crônica), o ofício intermediário entre o literato e o jornalista (o cronista), entre outras.

A imersão em algumas crônicas do período recortado (finais do século XIX, começos do XX) revela assuntos pertinentes ao entendimento do significado do urbano no contexto moderno, tais como o encantamento pelas ruas, traduzido na descrição panorâmica de seus espaços, na fisiologia de seus habitantes, no fluxo de informações que as ruas fornecem. Por fim, derivam-se daí cruzamentos 
entre a teoria e os produtos textuais selecionados e discute-se a figura do jornalista-flâneur na sua especificidade pioneira.

Porque é da experiência de passagem do grande literato para o pequeno (miúdo) cronista das ruas que se extrai a filosofia (não total, porém ambígua e aberta) dos tempos. E, para isso, o papel da crônica, essa cultura marginal diante da Cultura, adquire importância decisiva. A crônica, por ser uma estrutura que não faz parte da escritura canônica, talvez documente melhor o movimento impreciso da história (assim como Benjamin optou pelo drama barroco alemão do século XVII, e não pela forma mais bem acabada de drama - o espanhol - porque da sua imprecisão e da sua exclusão do sentido tradicional de belo é que poderia ser derivada a imperfeição de uma história que se queria linear e contínua).

Afinal, na perspectiva benjaminiana, são as formas abandonadas, não muito lembradas pela historiografia oficial, que revelam a verdadeira história se representando. Ou nas palavras de Machado de Assis (1998, p. 336), em crônica do dia 22 de março de 1886, da Gazeta de Notícias: "A história estuda-se em documentos assim, não preparados, mas ingênuos e sinceros; é deles que se pode sacar a vida e a fisionomia de um tempo".

\section{Referências}

ANTELO, Raúl. João do Rio: o dândi e a especulação. Rio de Janeiro: Taurus-Timbre, 1989.

BENJAMIN, Walter. Charles Baudelaire: um lírico no auge do capitalismo. Tradução de José Carlos Martins Barbosa e Hemerson Alves Baptista. 3.ed. São Paulo: Brasiliense, 1994. 
CANDIDO, Antonio. A vida ao rés-do-chão. In: . et al. A crônica: o gênero, sua fixação e suas transformações no Brasil. 108 Campinas; Rio de Janeiro: Ed. da UNICAMP/Fundação Casa de Rui Barbosa, 1992.

DAMATTA, Roberto. A casa e a rua: espaço, cidadania, mulher e morte no Brasil. Rio de Janeiro: Guanabara, 1987.

DELGADO, Manuel. El animal público: hacia una antropologia de los espacios urbanos. Barcelona: Anagrama, 1999

FOLHA DE S. PAULO (Org.). Machado de Assis: crônicas escolhidas. São Paulo: Ática, 1994.

LINS, Osman. Guerra sem testemunhas: o escritor, sua condição e a realidade social. São Paulo: Ática, 1974. (Coleção ensaios, v. 2).

MACHADO DE ASSIS. Memórias póstumas de Brás Cubas. 3.ed. São Paulo: FTD, 1992.

MEYER, Marlyse. Voláteis e versáteis. De variedades e folhetins se faz a chronica. In: CANDIDO, Antonio... et al. A crônica: o gênero, sua fixação e suas transformações no Brasil. São Paulo: Editora da UNICAMP; Rio de Janeiro: Fundação Casa Rui Barbosa, 1992. p. 93-133.

PAIVA DE LUCA, Heloisa Helena (org.). Balas de estalo de Machado de Assis. São Paulo: Annablume, 1998.

RIO, João do. A alma encantadora das ruas: crônicas. 5. reimpr. São Paulo: Companhia de Bolso, 2011 
ROCHA, Ana Luiza Carvalho da; ECKERT, Cornélia. O tempo e a cidade. Porto Alegre: Editora da UFRGS, 2005.

TRAVANCAS, Isabel Siqueira. O mundo dos jornalistas. 4.ed. São Paulo: Summus, 2011. 


\section{"Afinal de contas, autoajuda funciona ou não?": Apontamentos sobre o estudo antropológico de produtos culturais}

Talita Castro

\section{Situação 1:}

Ano de 2007, cidade de São Paulo.

Sexta-feira, por volta das oito horas da noite, resolvi matar o tempo da espera pelo encontro combinado com um amigo dentro de uma livraria, garimpando alguns títulos para a minha pesquisa de mestrado em antropologia social que se aproximava do fim do seu primeiro ano. Sentei em um dos pufes da Livraria Cultura localizada no Conjunto Nacional, complexo arquitetônico da Avenida Paulista, com cinco ou seis livros da sessão de autoajuda no colo. Todos os títulos falavam do mesmo assunto: relacionamentos afetivos problemáticos e estratégias para sua superação, e se dirigiam a um público leitor feminino. Fiquei por ali a folheá-los durante aproximadamente quarenta minutos. A loja estava cheia e em torno dos poucos pufes, bastante disputados pelos clientes, costuma formar-se uma espécie de fila invisível. Como a hora marcada se 
aproximava, deixei os volumes em um bloco de espuma que faz as vezes de mesa perto dos pufes, onde muitos livros são colocados, e me levantei. Meu lugar foi prontamente ocupado por duas mulheres, mais velhas que eu, aparentando por volta dos cinquenta anos de idade. Eu ainda estava perto quando pude escutar, vinda de uma delas, uma exclamação que coaduna com boa parte das impressões sobre autoajuda que venho recolhendo ao longo destes anos de pesquisa. Ao passar os olhos pelos livros que eu havia deixado ao lado do pufe, com certo desprezo visível, ela disse: "nossa, essa daqui estava desesperada!".

\section{Situação 2:}

Em agosto do ano seguinte, como parte da pesquisa, comecei a estabelecer contatos com autores dos livros catalogados como autoajuda com os quais eu estava trabalhando, em busca de entrevistas e/ou depoimentos sobre os textos, mercado editorial e motivações para publicações. Nesse sentido, algumas respostas de Andrea Franco, autora de 40 sim! E daí? Um guia de qualidade de vida para as mulheres depois dos 40 anos, chamaram a minha atenção justamente pela sua ênfase no distanciamento do rótulo da autoajuda. Através de correspondência eletrônica, Andrea me falou sobre a rubrica editorial que seu livro recebeu:

Nunca me preocupei com a classificação de autoajuda. O livro não tinha essa intenção. Não fiz nenhum esforço para me distanciar da autoajuda. Quando eu disse que o meu livro não era desse ramo, foi porque ele não é do tipo: "Como ser sexy depois dos 40 anos”, entendeu? Isso é autoajuda! E o meu livro não é assim. O objetivo não é esse! O objetivo é promover a saúde e o bem-estar na 
maturidade através de informações de médicos e outros especialistas. Não leio autoajuda. Não é preconceito, mas sempre estive envolvida com outros livros. (Andrea Franco, autora do livro: 40 sim! E daí? Um guia de qualidade de vida para as mulheres depois dos 40 anos - Grifos do autor).

\section{Situação 3:}

Algumas reações são comuns em duas ocasiões nas quais tenho oportunidade para falar da minha pesquisa: em encontros acadêmicos, mais ou menos formais, ou quando sou solicitada por jornalistas para comentar "o sucesso da autoajuda", desde que a defesa da minha dissertação me alçou à categoria de especialista no tema. Falo aqui mais especificamente de risos e de uma simpatia quase que imediata ao meu discurso, que contrasta radicalmente da recepção que trabalhos construídos em torno de temas mais ortodoxos dentro da disciplina costumam receber ${ }^{22}$. Uma reação praticamente certa é o questionamento que dá título a este trabalho - "e você acha que autoajuda funciona mesmo?" -, feito pelos pares acadêmicos em tom mais jocoso, justiça seja feita, do que por quem me aciona para contribuir com alguma reportagem ou matéria jornalística. Destaco ainda outra indagação, restrita ao ambiente acadêmico, que já me foi feita muitas vezes por colegas: "na verdade, você está estudando autoajuda para depois escrever o seu próprio livro [e ficar rica], não é?”.

As três situações relacionadas acima revelam sentidos atribuídos a um complexo e apenas aparentemente homogêneo conjunto

22 Reação para a qual, acredito eu, a minha postura certamente mais informal do que o esperado nestas circunstâncias certamente contribui. 
de discursos associados ao termo autoajuda ${ }^{23}$ que parecem respingar no trabalho de pesquisa que se pretende fazer sobre ele. $\mathrm{O}$ objetivo deste texto é abordar a imagem negativa que essa produção cultural recebe em diversos contextos por diferentes atores, sejam eles possíveis leitores, autores ou produtores de conhecimento, tanto na mídia quanto em ambientes de pesquisa acadêmica. Tomando o lugar que me cabe, o de pesquisadora, entre esta tríade de posições, trata-se de buscar compreender as expectativas externas ao meu trabalho que, de certa forma, projetam juízos de valor sobre o universo empírico das minhas investigações e parecem impor, como ponto de partida, uma relação de descrença nos efeitos desta produção cultural e descrença em relação à própria seriedade da minha investigação antropológica ${ }^{24}$. Tudo se passa como se fosse preciso, a princípio, negar a autoajuda para poder realizar um estudo crítico sobre algo que é sempre definido pela negativa e pelo afastamento ${ }^{25}$.

23 Salem, 1992b, p.2.

24 Assim como Carolina Parreiras relatou sobre sua pesquisa no Orkut em “'Não leve o virtual tão a sério'? Uma breve reflexão sobre métodos e convenções na realização de uma etnografia do e no on-line", de 2011.

25 As reflexões aqui propostas são um desenvolvimento da minha dissertação de mestrado em antropologia social, Auto-ajuda e a reificação da crise da meia-idade, defendida no final de 2009 pela Universidade Estadual de Campinas (UNICAMP), e da pesquisa de doutorado que venho realizando desde então na mesma instituição. Os dois trabalhos contaram e contam atualmente com financiamento da Fundação de Amparo à Pesquisa do Estado de São Paulo (FAPESP) e versam sobre concepções de curso de vida cristalizadas na produção nacional e internacional de literatura de autoajuda, por meio da mediação da operatória de marcadores sociais da diferença como gênero, geração e classe social. Cabe destacar que meu trabalho não se baseia em uma pesquisa de recepção, mas sim no conteúdo dos livros e em contatos com autores e agentes do mercado editorial - opções que certamente acirram os estranhamentos aqui abordados. 
Como ponto de partida da reflexão, apresento dois textos literários, com registros catalográficos diferentes, que têm nas imagens do que se entende por autoajuda suas principais motivações. A saber, o romance Ser feliz ${ }^{\oplus}$, de 2001, do canadense Will Ferguson, e o conto "Livros de autoajuda: como largar este vício", do escritor pernambucano radicado na cidade de São Paulo, André Laurentino, publicado na coletânea de 2007, intitulada 35 segredos para chegar a lugar nenhum: literatura de baixo-ajuda, organizada pela socióloga e escritora paulista Ivana Arruda Leite.

"Se, um dia, alguém escrevesse um livro de auto-ajuda que realmente funcionasse, que sanasse nossos infortúnios e eliminasse nossos maus hábitos, os resultados seriam catastróficos" (FERGUSON, 2003, p.8). Esse axioma serviu de inspiração ao canadense Will Ferguson para que ele escrevesse seu romance. Ouvido originalmente da boca de uma assessora de imprensa, referia-se originalmente aos estragos que um exemplar de autoajuda definitivo traria para o mercado editorial. Mais de dois anos depois, o autor publica sua sátira apocalíptica sobre os efeitos de um livro que garantisse o bem-estar e a resolução dos problemas que a maior parte dos títulos do gênero promete. $\mathrm{E}$ a ironia da narrativa revela uma dimensão importante da imagem negativa que a autoajuda possui: a saber, a ideia de que se trata de elemento próprio a uma economia de frustrações que não pode atuar significativamente sobre as angústias às quais se dirige, sob a pena desta própria dinâmica mais geral desaparecer.

Ser feliz ${ }^{\oplus}$ acompanha a entediante rotina do editor literário Edwin Vincent de Valu, empregado no Departamento de NãoFicção da Panderic Inc., editora fictícia de porte médio no cenário estadunidense. Edwin é construído por Ferguson como um sujeito comum, ordinário: quase um completo perdedor, frustrado e cético por natureza e por ocasião. Tendo de gastar boa parte de seu tempo 
de trabalho na peneira dos chamados manuscritos "não solicitados e sem agente" (FERGUSON, 2003, p.28) enviados à editora, de Valu adquirira algum grau de impaciência para tratar o material - a chamada pilha de baboseiras - e também o resto de sua vida.

A prosa ácida de Ferguson descreve a guinada que o cotidiano de Edwin sofre a partir do momento em que toma em suas mãos pela primeira vez o original de Tupak Soiree, $O$ que aprendi na montanha. $\mathrm{O}$ calhamaço de quase mil páginas, datilografado à mão numa velha máquina de escrever, com pequenos adesivos de margaridas dispostas aleatoriamente em suas laudas, parecia recusar-se aos padrões editoriais nos quais Edwin se esforçava para enquadrá -lo. Nas palavras do próprio personagem:

É um manuscrito muito estranho. É longo, complexo e, pelo que parece, não tem uma forma ou uma estrutura clara. Eu tinha imaginado que seria disposto da maneira habitual, dividido em capítulos - você sabe, um sobre cigarro, um sobre planejamento financeiro, outro sobre alcançar a felicidade interior etc. etc. -, mas na verdade é um longo monólogo divagante, os elementos separados vão se entrelaçando para formar um todo. $\mathrm{E}$ o mais esquisito é que, embora não tenha estrutura alguma, não no sentido clássico, o livro tem um fluxo definido. Tudo se relaciona com todo o resto. Soiree passa de um argumento para o seguinte sem que a gente nunca saiba realmente quando termina uma seção e começa outra. E o texto? Às vezes é terrível: corriqueiro, ralo e cheio de chavões. Outras vezes é uma prosa linda, quase profunda. Há seções inteiras que parecem saídas de dentro de um manual básico de auto-ajuda, felizes e oh, tão sinceras, e aí, de repente, ele envereda 
por uma metafísica e o dilema da identidade do ser humano. É uma miscelânea. (FERGUSON, 2003, p. 107 - 108).

Após ter sido perdido e recuperado, e escapar de uma edição radical para ser publicado como Bombons para a alma, o original de Soiree é enviado à gráfica intacto, "sem alarde nem publicidade" (FERGUSON, 2003, p. 163), inaugurando o fim do mundo, conforme o conhecemos ${ }^{26}$. A partir daí, a saga do "livro de auto-ajuda definitivo" (FERGUSON, 2003, p. 39) narra a destruição de gigantescas instituições ocidentais contemporâneas, dependentes basicamente de frustrações e ansiedades humanas, tais quais as indústrias do tabaco, álcool e drogas ilegais, o trânsito nas grandes cidades e as variadas tendências da moda, para citar alguns exemplos. Ao passo em que os recordes de venda do exemplar são continuamente estabelecidos e solapados, multiplicam-se os avisos de "fui pescar" nas portas dos grandes escritórios, sintomáticos da adesão dos leitores, até então executivos e workaholics de marca maior, à "receita para a humanidade" (FERGUSON, 2003, p. 32) de Soiree. E somente o editor deste petardo silencioso, de Valu, parece perceber - e temer - o que se passa ${ }^{27}$.

26 Fórmula que dá nome à segunda parte do romance.

27 Em uma conversa com a também editora May Weatherhill, Edwin faz seu diagnóstico catastrófico, suspeitando de que o livro pudesse ser fruto de algum programa secreto de computador: "May, tudo está prestes a ruir à nossa volta. Tudo. Estou falando da sociedade, do país, da economia. É o fim da vida como a conhecemos. E por quê? Por causa de Tupak Soiree e da fórmula dele, produzida por computador, para a felicidade humana. Você disse 'então as pessoas se tornam felizes, que mal há nisso?' May, toda a nossa economia foi construída sobre as fraquezas humanas, sobre maus hábitos e inseguranças. Moda. Lanches rápidos. Carros esporte. Engenhocas tecnológicas. Acessórios para sexo. Centros de dieta. Clubes de homens carecas. Pequenos anúncios. Seitas religiosas esquisitas. Times esportivos profissionais. Salões de cabeleireiro. Crises de homem na meia idade. Extravagâncias de compras. Todo o 
A grande percepção de Ferguson, materializada nas angústias proféticas do editor, parece estar no ato de revelar, com sarcasmo e desprendimento, as razões para o sucesso da autoajuda. Ser feliz ${ }^{\varnothing}$ descortina os meandros desse nicho editorial ao narrar a saga de uma publicação que se diferencia do que se encontra no mercado justamente pela sinceridade em assumir seus mais negativos estereótipos: por exemplo, o de que só existem muitos títulos porque nenhum deles até hoje funcionou ${ }^{28}$. Sua fórmula carrega uma concepção de humanidade - bastante etnocêntrica, há de se dizer, fortemente centrada em anseios de consumo - que é radicalmente ameaçada pela satisfação simples e pacífica, no sentido mais morno da palavra, trazida pela leitura do best-seller. O que aprendi na montanha tem consequências drásticas para a humanidade porque esgota o que chamei acima de economia de frustrações, dinâmica que sustentaria o mercado editorial em questão mas também uma série de outras indústrias da sociedade contemporânea. Nas palavras de Valu:

Eu edito livros de auto-ajuda. Pode acreditar em mim, eu sei. Todo mundo está procurando alguma coisa e a questão é que essa coisa nunca é encontrada. Todo mundo precisa de ajuda. Ou no mínimo pensa que precisa (FERGUSON, 2003, p. 176).

nosso estilo de vida é construído sobre falta de autoconfiança e insatisfação. Pense no que aconteceria se as pessoas fossem realmente felizes, felizes mesmo. Realmente satisfeitas com a própria vida. Seria uma catástrofe. O país inteiro pararia - e se os Estados Unidos pararem, você não acha que o resto do mundo ocidental para também? Estamos falando de um efeito dominó em escala global. O fim da história” (FERGUSON, 2003, p. 228 - 229).

28 Ferguson (2003, p. 172). 
E a ironia da narrativa de Ferguson reside no fato de que o autor do livro de grande sucesso da sua ficção não tem problemas em assumir posições das quais os escritores de livros catalogados como autoajuda na vida real buscam se afastar constantemente. Falo aqui mais especificamente da ideia do guru ou dono da verdade, capaz de doar receitas eficazes para seus leitores. Ferguson apresenta o autor de autoajuda como alguém que sabe ser dotado do poder para transformar toda uma civilização e que parece não se importar tanto com isso. E mais: como alguém que se utiliza disso simplesmente para ganhar dinheiro, como é o caso do autor de $O$ que aprendi na montanh ${ }^{29}$. Soiree choca de Valu porque oferta na medida exata e, por isso mesmo, catastrófica, justamente aquilo que todo leitor de autoajuda buscaria em tais publicações: uma receita eficaz para a felicidade. E é tal franqueza de propósitos que contrasta com a autoajuda para além da ficção tão real criada por Ferguson.

Se há algo que parece alinhavar a diversidade dessa produção literária trata-se justamente da insistência dos autores na recusa em assumir a posição de Soiree ${ }^{30}$. Para a autoajuda de carne e osso é importante localizar no leitor os dispositivos empoderantes, afastando de quem escreve o autoritário posto de dono da verdade. São informações científicas, para uns, e experiências de vida compartilhadas, para outros, que possibilitam as reflexões daqueles que buscam suas páginas. $\mathrm{E}$ o tom da escrita deve ser, quase sempre, $\mathrm{o}$ de uma conversa, como se o autor estivesse apenas acompanhando o leitor em sua jornada de (auto) conhecimento e transformação

29 "Quer saber o meu segredo? Não há segredo. Eu apenas sentei e bati à máquina. Escrevi tudo de uma vez só, sem parar para reescrever ou mesmo conferir o que tinha escrito. Achei que era na auto-ajuda que estava o dinheiro. Quer saber por que escrevi o livro? Pelo dinheiro, pura e exclusivamente." (FERGUSON, 2003, p. 356).

30 Posição válida, ao menos, para aqueles com os quais venho travando contato ao longo da pesquisa. 
pessoal. Como coloca Regina Lemos, autora de Quarenta: a idade da loba, de 1994: "Assumir posturas, sim, como há várias posturas assumidas ao longo deste livro. Mas dar conselhos, não. Contar histórias, trocar experiências, conversar [...]" (LEMOS, 1996, p. 19).

Em outra prateleira da livraria, reservada para livros nacionais de humor, 35 segredos para chegar a lugar nenhum: literatura de baixo-ajuda reúne, como seu título diz, trinta e cinco textos de diversos autores brasileiros, organizados por Ivana Arruda Leite, que ironizam alguns dos principais clichês do mercado da autoajuda. A maior parte dos contos se constitui formalmente como receituário e aborda questões fúteis ou absurdas, ironizando a maneira supostamente superficial com a qual as publicações de autoajuda abordariam dilemas subjetivos e existenciais. Cito, por exemplo, "Sete passos para mulheres medíocres capturarem um homem idem", de Ana Elisa Ribeiro; "Como manter a elegância enquanto seu marido dá em cima de outra", de Adrienne Myrtes; "Como transar com o marido da sua melhor amiga sem pôr em risco a amizade entre vocês", da própria Ivana organizadora do volume; "Como sorrir no retrato de família", de Lívia Garcia-Roza; e "Como continuar gostando de viver mesmo à beira da destruição total da humanidade", de Rodrigo Lacerda. Por meio de correspondência eletrônica, Leite me revelou as motivações para o livro: "surgiu da raiva que nós escritores temos dos livros de autoajuda. Um misto de raiva e inveja por eles venderem tanto e terem tanto público".

Em "Livros de auto-ajuda: como largar este vício", o escritor e publicitário André Laurentino, que publica quinzenalmente no jornal O Estado de São Paulo, constrói a caricatura do leitor viciado em livros de autoajuda. A própria possibilidade de que tal figura possa existir, ainda que apresentada ironicamente, ilustra um elemento constituinte da imagem negativa desse gênero discursivo que venho 
comentando: a noção de que há e deve haver certo grau de falibilidade em todo volume catalogado como autoajuda.

$\mathrm{O}$ texto tem apenas quatro páginas, é bastante direto, e traz algumas marcas que indicam que se trataria, na verdade, da tradução de um original na língua inglesa ${ }^{31}$. No estilo de um arrogante guru da verdade e aos moldes dos programas de passos, populares em tratamentos de desintoxicação, o autor dispõe sua receita na forma de um método cujo nome é formado por um acrônimo de seus próprios estágios:

O Método Q.U.I.T. - Como fazer? Q.U.I.T. consiste em quatro passos fáceis para se livrar do problema, e qualquer pessoa de mediana capacidade consegue cumpri-lo. Até mesmo VOCÊ! Basta seguir a sequência do Q.U.I.T. ${ }^{\circledR}$ e certamente você sairá um VENCEDOR (LAURENTINO, 2007, p. 30).

Os quatro passos consistem em: questionar, entender, inibir e exterminar os sinais indicativos do vício em autoajuda. $\mathrm{O}$ primeiro e o terceiro momentos do método, assim como o próprio acrônimo que o batiza, fazem referência ao suposto original em inglês. Entender está representado pela letra $\mathrm{U}$, já que diz respeito ao termo understand, seu equivalente em inglês; assim como exterminar, provavelmente aparece como uma tradução de terminate, com a última inicial do nome, a letra $\mathrm{T}$. $\mathrm{E}$ o próprio nome do método torna-se um chiste ao fazer clara referência ao termo quit, que pode ser entendido como uma tradução do verbo desistir - atitude das menos louváveis

31 Cabe destacar que é nos Estados Unidos da América, no começo do século XX, que a autoajuda, nascida na Europa, ganha popularidade em vendas e os tons de psiquismo e de uma terapêutica da personalidade com os quais a identificamos atualmente (BOSCO, 2001, p. 10). 
quando se pensa em autonomia e responsabilidade, temas evocados por boa parte do material de autoajuda (RÜDIGER, 1996, p. 123; CASTRO, 2009, p. 87).

Se o romance de Ferguson me interessa principalmente por revelar, por meio da ironia, significados associados à figura do autor de autoajuda, Laurentino aborda de maneira escrachada estereótipos associados aos leitores do gênero. Logo em seu segundo parágrafo coloca:

Observo que, na maioria das vezes, as pessoas [que] tomam contato com estes livros porque são gordas, ou depressivas, ou fracassadas, ou têm casamentos infelizes, ou mexem com queijos. Não são tipos interessantes, acredite. Mas estes são apenas os mais fáceis casos - e não são eles que me abordam na rua. / Pois os viciados em livros de autoajuda são aqueles que se enquadram em TODOS os casos acima. Isto é para dizer: são um bando de sangrentos perdedores!!! Ao lerem livro depois de livro para curar tantos e tantos problemas, acabam adquirindo o mais terrível deles. Isto mesmo: o vício em autoajuda! (LAURENTINO, 2007, p. 29).

Diferentemente do que colocam os escritores com quem venho dialogando, este autor fictício de autoajuda, justamente por partir do pressuposto de que seus leitores são perfeitos fracassados, é categórico ao afirmar que ele e seu livro é que serão responsáveis pelas transformações em suas vidas. Não há espaço para modéstia nem para o reconhecimento das capacidades de quem o lê.

Para entender o problema, precisamos entendê-lo.

Vejamos: o termo autoajuda vem da combinação 
de dois terríveis fatores: auto (ou seja, você) + ajuda. Tudo que envolve você resume-se a FRACASSO. Principalmente quando você resolve ajudar alguém. Principalmente se este alguém é você novamente. De uma vez por todas, ENTENDA isto: um fracassado não é a melhor pessoa para ajudar outro fracassado. Pior ainda se eles forem a mesma pessoa. Foi por isso que você comprou este livro. ELE é que vai ajudá-lo a se livrar da autoajuda!!! Isto não parece brilhante? (LAURENTINO, 2007, p. 31). [Grifos do autor].

E o texto ainda termina com mais um comentário sarcástico a uma tendência comum no mercado das publicações de autoajuda: a significativa quantidade de títulos autorreferenciados ${ }^{32}$, encarada como simples estratégia de mercado.

Se você achou o fim algo abrupto, ainda não está pronto. Compre outro exemplar e volte ao passo Q. Mas se está realmente curado, você deve ser capaz de lançar este livro ao lixo. E assim partiremos um do outro, para nunca mais nos vermos. Se você for capaz de fazer isto, agora, parabéns! VOCÊ CONSEGUIU! Mas não o faça antes deste

32 O líder de vendas $O$ segredo, de Rhonda Byrne, publicado em 2006, deu origem a uma avalanche de outras publicações. Entre estas, cito: A chave do maior segredo do mundo, do brasileiro Lauro Trevisan, publicado em 2007; A chave do segredo, de Esther \& Jerry Hicks, também publicado em 2007; A ciência por trás do segredo, publicado por Wallace Wattles em 2008; Lições de um mestre: o segredo além do segredo, publicado por John McDonald também em 2008; e, por fim, Muito além do segredo, de Ed Gungor, publicado em 2007, que se dispõe a conciliar a lei da atração de Pyrne com dogmas cristãos. Vale lembrar que o livro que inspira todos estes já é uma adaptação de um filme, homônimo, lançado no mesmo ano, composto por testemunhos de pessoas que conheciam então o tal segredo. 
último conselho: Último conselho! Compre e tenha sempre à mão o meu segundo livro: Como livrar-se de uma recaída. Por apenas US $\$ 45,99$. Não saia de casa sem ele. Até lá! (LAURENTINO, 2007, p.31-32). [Grifos do autor].

Juntos, os textos de Ferguson e de Laurentino, assim como as situações descritas no início deste trabalho, informam-nos sobre um conjunto mais ou menos estável de significados pejorativos associados ao termo e aos livros classificados como autoajuda. Até aqui, pode-se dizer que o leitor do gênero é entendido como alguém superficial, preguiçoso e carente; e o autor é pintado como um interesseiro e arrogante ao se colocar como dono de uma verdade generalizada, supostamente válida para todo tipo de leitor. $\mathrm{E}$ os livros são quase sempre identificados como listas de passos, soluções infalíveis, receitas para a vida das pessoas. $\mathrm{O}$ ideal do manual, negativamente encarado, sobressai-se. A seguir, busco compreender as origens históricas deste formato de produção literária e suas relações com os dados que encontrei em minha própria pesquisa.

Antes disso, um último registro de pesquisa. Recentemente, fui procurada por um jornalista da Revista Gloss, da Editora Abril, que se define como "o guia prático e contemporâneo para a jovem que precisa encontrar o seu lugar no mundo", para falar sobre livros de autoajuda. $\mathrm{O}$ número cinquenta e seis da revista, lançado em maio de 2012, traz um editorial e uma matéria de dez páginas que procuram fornecer um norte para a leitora: ironicamente, um manual sobre manuais. A imagem abaixo é das duas primeiras páginas do texto, escrito por Sílvia Amélia de Araújo e Vinícius Luiz, e traz uma imagem do fotógrafo Eduardo Girão que sintetiza elementos que venho abordando até aqui. A leitora está deitada, suas feições 
ilustram surpresa e arrebatamento e o título do livro fictício que ela lê é Resolva seus problemas sem levantar do sofá.

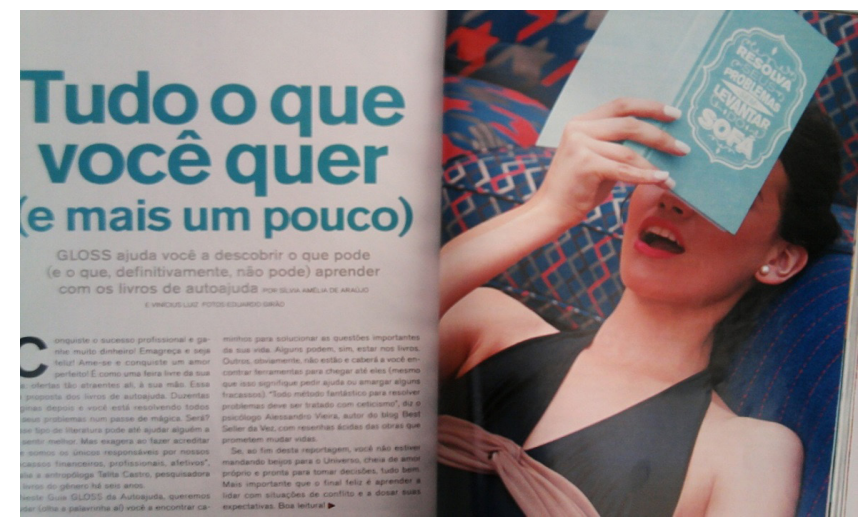

Imagem 1 - Fonte - Artigo da Revista Gloss da Editora Abril

Fonte - Fotógrafo - Eduardo Girão

O trabalho de Francisco Rüdiger, Literatura de auto-ajuda e individualismo: contribuição ao estudo da subjetividade na cultura de massa contemporânea, resultante da sua pesquisa de doutorado em sociologia pela Universidade de São Paulo, foi publicado pela primeira vez em 1995 e se estabeleceu como uma das principais referências nacionais e internacionais sobre a história desta produção e sobre suas razões sociológicas ${ }^{33}$. Em estilo de grande narrativa, e como o título sugere, trata-se de um estudo amplo, que toma a autoajuda como produto exemplar máximo da indústria cultural e, tautologicamente, como resposta eficaz às demandas histórico-sociais que sustentam seu próprio surgimento, ainda no

33 Além das citações em trabalhos brasileiros, também encontrei referências ao trabalho de Rüdiger em uma pesquisa de origem argentina (PAPALINI, 2009). 
século XIX ${ }^{34}$. Para Rüdiger, trata-se de pensá-la como operatória das exigências de individuação que se massificam no contexto moderno até os dias atuais. Suas reflexões estranham e relativizam o sujeito como dado ${ }^{35}$ e colocam essa produção cultural como um dispositivo, entre outros, a uma reflexividade propriamente individualista $^{36} . \mathrm{O}$ argumento, com suas próprias palavras:

A literatura de auto-ajuda constitui uma das mediações através das quais as pessoas comuns procuram construir um eu de maneira reflexiva, gerenciar os recursos subjetivos e, desse modo, enfrentar os problemas colocados ao indivíduo pela modernidade. $\mathrm{O}$ movimento dessa última desintegrou as representações coletivas e os simbolismos comuns que recomendavam a salvação do eu por meio da fusão dos propósitos pessoais com os propósitos da comunidade. $\mathrm{O}$ resultado desse processo foi a criação de uma sociedade de

34 "A literatura de auto-ajuda - o conjunto de relatos, de manuais, de textos, às vezes multimídia, que ensina como conduzir a vida, sobrepujar a depressão, manejar com pessoas, exercitar a sexualidade, parar de fumar, prosperar financeiramente, etc. - conta-se entre os fenômenos de indústria cultural que construíram seu próprio universo espiritual e responderam com sucesso às demandas colocadas pelas condições que suscitaram seu florescimento, engendrando, com o passar do tempo, uma série de práticas, sobretudo de leitura, através das quais o individuo comum vem tentando descobrir, dentro de si, os recursos e a solução dos problemas criados pela vida moderna." (RÜDIGER, 1996, p. 9).

35 "O indivíduo enquanto sujeito, como valor, não é meramente dado, precisa ser construído e conservado, através de um trabalho sobre si mesmo, dialeticamente mediado pela pessoa" (RÜDIGER, 1996, p. 238).

36 Anthony Giddens, em A transformação da intimidade: sexualidade, amor \& erotismo nas sociedades modernas, de 1992, coloca a autoajuda e também as ciências sociais como indices dos processos da reflexividade institucionalizada na modernidade (GIDDENS, 1993, p. 10). Angelo M. Bosco encerra o seu trabalho também colocando a autoajuda como mediadora eficaz para a construção de subjetividades (BOSCO, 2001, p. 87). 
indivíduos livres que convivem com uma comunidade degradada, mas também de um conjunto de problemas pessoais que tornou profundamente problemática essa liberdade. / Na modernidade, parece que a liberdade individual vai perdendo sentido à medida que aumenta a liberdade do homem. As práticas tecidas pela referida literatura representam um veículo dos diversos movimentos de subjetivação popular através dos quais o homem comum procura resolver esse paradoxo. (RÜDIGER, 1996, p. 14-15).

Popularizado nos Estados Unidos da América ao longo do século XX, o termo autoajuda surge, segundo o autor, na Escócia, em meados do século anterior. Escritor de tratados morais, o médico Samuel Smiles publica em 1859 Self-help - traduzido rapidamente no Brasil, que vivia um contexto socioeconômico bastante diverso, como Ajuda-te. ${ }^{37} \mathrm{O}$ inusitado da genealogia apresentada por Rüdiger está em enxergar neste marco inicial de uma produção tão própria à modernidade resquícios de outras disposições morais. A ideia de manipulação pessoal está presente, mas possui outros

37 O historiador Robert W. Slenes faz menção a estas traduções quando comenta sobre as preocupações e preconceitos da elite brasileira em relação ao comportamento das classes trabalhadoras no final do século 19: “... havia o reconhecimento tácito de que o 'aburguesamento' do modo de ser do trabalhador livre não aconteceria por um processo natural, mas dependeria da 'tutela' da própria burguesia e do Estado. No Brasil, o problema da transição do trabalho escravo ao trabalho livre, que levantava o espectro de uma mudança profunda nas práticas disciplinares, provavelmente fez com que parecesse especialmente necessária a adoção de estratégias de tutela. Chama a atenção, nesse sentido, que pelo menos três dos livros de Samuel Smiles, o propagandista escocês das virtudes da 'economia doméstica moral' e das vantagens provenientes da 'subordinação do apetite animal à razão, à providência e à prudência', haviam sido traduzidos para o português e publicados no Rio de Janeiro até 1880" (SLENES, 1999, p. 141). 
fins. Buscando alguma conservação moralista em um contexto social de fortes transformações, o trabalho aparece como categoria moral importante, já que incita à disciplina, obediência, atenção e perseverança. $\mathrm{O}$ objetivo deste e de outros tratados é a conservação pessoal por meio de um equilíbrio subjetivamente tranquilo entre padrões mais tradicionais de sociabilidade e alguns processos de individualização que se acirram. A autoajuda de Smiles erige-se em representações sobre a humanidade que se diferenciam bastante daquelas que sustentam os estereótipos em Ser feliz $z^{\circledR}$ :

Assim, verifica-se que o homem como sujeito que vive para satisfazer suas necessidades, o homem do desejo descoberto pelo pensamento psicológico moderno, é uma figura estranha a essa doutrina da auto-ajuda. Neste contexto, o homem definese como sujeito que pode transformar o dever em hábito, construindo praticamente o conceito de sua vida através do trabalho empregado em sua carreira durante toda sua existência. O homem de valor, por conseguinte, não é o homem que deseja, que vence ou que crê, mas o homem que labora e produz; que é cuidadoso com os pequenos detalhes de seu ofício. (RÜDIGER, 1996, p. 44).

Como coloca Angelo Bosco, que também se inspira no trabalho de Rüdiger para construir a sua análise em Sucessos que não ocorrem por acaso: literaturas de auto-ajuda, dissertação de mestrado em sociologia de 2001, trata-se de uma produção preocupada com o resgate de virtudes pessoais que estavam sendo solapadas em virtude de novas necessidades provocadas por transformações sociais em curso. Segundo Bosco, é com a apropriação do termo autoajuda por autores estadunidenses, já na virada para o século XX, que os sentidos se deslocam desse referencial e denotam, gradualmente, 
uma perspectiva mais terapêutica no sentido da valorização e construção de uma individualidade única, atraente e destacada ${ }^{38}$. Para este autor, isso tem a ver com o próprio desenvolvimento da economia de mercado e com o florescimento de grandes organizações empresariais, para as quais tais condições são eleitas como parte imprescindível do perfil profissional almejado: trata-se da valorização do fator humano em um contexto de crescente burocratização das atividades de trabalho.

O chamado Novo Pensamento, "verdadeiro movimento de auto-ajuda” (RÜDIGER, 1996, p. 72), é tomado pelos autores em questão como uma espécie de meio caminho dentre as transformações pelas quais passa o gênero desde seu surgimento até os dias atuais. Trata-se do desenvolvimento de teorias mentalistas para a solução dos problemas das pessoas que se distanciam de afirmações de fundo mais moral em busca de tratamento e legitimação de cunho cientificista. Segundo Rüdiger, esse tipo de postura se enrijece com o advento da chamada Psicologia Positiva ${ }^{39}$. Os mandamentos morais gradualmente perdem espaço para a contínua reiteração da força de vontade que, cada vez mais, remete a técnicas para indução de estados mentais agradáveis e para a produção

38 "Ao final do século XIX e início do século XX, a literatura do sucesso apresenta mudanças de direção e desloca-se do cultivo das virtudes para o desenvolvimento das qualidades da personalidade. A mudança sugere o esmorecimento dos ideais associados ao bem-estar da comunidade, intensificando, ao mesmo tempo, a ideia de uma competição entre indivíduos, que se fundamenta, principalmente, no cultivo das habilidades pessoais." (BOSCO, 2001, p. 10).

39 "A psicologia positiva é um movimento recente dentro da ciência psicológica que visa fazer com que os psicólogos contemporâneos adotem uma visão mais aberta e apreciativa dos potenciais, das motivações e das capacidades humanas." Cf. http:// pt.wikipedia.org/wiki/Psicologia_positiva. 
e alteração de novas realidades. O que se reafirma são os poderes $d a$ mente para atrair prosperidade e bem-estar:

O princípio básico da nova ciência reduzia-se, como ainda hoje, à seguinte fórmula: o sucesso na vida pode ser mentalizado e colocado sob domínio do pensamento. $\mathrm{O}$ pensamento pode se transformar em ação, é a chave para ser bem sucedido (RÜDIGER, 1996, p. 88).

Gradualmente, a personalidade individual ganha ares de coisa maleável e os how-to-do books popularizam-se, na década de 1930, como manuais para a manipulação da personalidade ${ }^{40}$. $\mathrm{O}$ maior best-seller de autoajuda ao longo de todo o século XX - e um dos maiores de toda a história mundial do mercado editorial - é publicado em 1936: Como fazer amigos e influenciar pessoas, de Dale Carnegie. Segundo as estimativas de Rüdiger, teria vendido mais de quinze milhões de exemplares em todo o mundo desde então ${ }^{41}$. É próprio deste momento a valorização de técnicas de comportamento e comunicação em detrimento dos procedimentos de mentalização, que perdem popularidade nas publicações. Não são gratuitas as descobertas de Rüdiger sobre outras ocupações destes autores, vanguarda do que o autor chama de novo ethos da personalidade: eram oradores, encabeçavam cursos de treinamento profissional e estavam concatenados com técnicas de pesquisa de

$40 \operatorname{Bosco}$ (2001, p. 13).

41 "A documentação disponível demonstra sem dúvida que, durante os primeiros anos do século XX, diversos escritores e filósofos populares sublinharam as vantagens de saber explorar os recursos da expressão pessoal, recorrendo para tanto aos mais variados princípios doutrinários. Entretanto, o verdadeiro desenvolvimento dessa tendência de auto-ajuda ocorreu mais tarde, devendo-se sobretudo à intervenção de Dale Carnegie." (RÜDIGER, 1996, p. 115). 
mercado para conduzirem cientificamente suas colocações. É nesse momento, marcado pela grande popularização destas publicações, que começa a se solidificar a concepção da autoajuda como manual, receituário para a produção de determinados resultados esperados: seja ele a conquista de popularidade, como o best-seller de Carnegie indica, ou de autoconfiança, como Norman Vicent Peale, outro grande nome do gênero, propõe na década seguinte em Como confiar em si mesmo e viver melhor, de 1948. O rótulo de advice books - livros de conselhos, numa tradução literal - dado pelo mercado estadunidense a muitos títulos que no Brasil são catalogados como autoajuda não deve ser tomado como algo gratuito, portanto. Aliás, muitos dos trabalhos estrangeiros que me servem de referencial teórico para a análise utilizam esta terminologia para definir seus universos de pesquisa ${ }^{42}$.

$\mathrm{O}$ que as falas dos autores com quem entrei em contato - e os estereótipos presentes em Ser feliz ${ }^{\circledast}$ e no conto de Laurentino parecem indicar que é esse tipo de representação que se tem como dado quando se pensa em autoajuda. E é essa imagem forte que os impele a negar quase que veementemente o posto daquele que sabe como fazer alguém, seu leitor, alcançar determinado objetivo. Por isso, a postura mais recente do diálogo que busca ruir com hierarquias entre autor e leitor, da livre exposição de histórias de vida que, de alguma forma - nunca ofertada como a melhor de todas - lidaram com problemas tomados como questões privadas ${ }^{43}$. É

42 Este é o caso, por exemplo, de algumas publicações da socióloga estadunidense Arlie Hochschild como a que ela escreve em parceria com a socióloga japonesa Kazuko Tanaka "Light and heavy: american and japanese advice books for women" (HOCHSCHILD; TANAKA, 2003).

43 “[...] podemos dizer que, socialmente, os tratados do gênero representam um território, ou campo de experiência, do problema que segmentos expressivos das camadas médias urbanas são para si mesmos enquanto coletivo de indivíduos; constituem 
na multiplicidade de informações e de narrativas que parece estar a possibilidade de comunicação, aprendizado e transformação. As palavras da cientista política Lúcia Avelar no início do Prefácio de Quarenta: a idade da loba, de Regina Lemos, são sintomáticas nesse sentido:

\begin{abstract}
[...] ao iniciar a leitura de Quarenta, construído a partir de relatos de mulheres de todas as partes deste imenso e diverso país, não conseguia mais parar. Vi-me levada de um relato a outro, sentindo-me como se eu estivesse ali, com cada entrevistada, aprendendo coisas sobre os meus sentimentos, a minha sexualidade, só que pela voz de outras mulheres. Com cada entrevistada de Regina Lemos, eu ampliava a minha percepção sobre 'lados' meus e sobre dificuldades que eu julgava serem apenas minhas, nesta lúcida (embora nem sempre fácil) caminhada de viver, não conforme regras preestabelecidas, mas escutando a própria voz interior. Senti, então, ressonância (LEMOS, 1996, p. 13) [Grifo do autor].
\end{abstract}

uma tentativa de articular, para essas pessoas, uma resposta interior à transformação nas necessidades metafísicas em problema privado, verificada em nossa civilização. / A literatura do gênero, sabemos, é formada, sobretudo, por manuais e textos de prática, que contém basicamente, 'uma metodologia para conquista do sucesso material, isto é, riqueza e poder; um conceito a respeito da autorrealização pessoal e sobre os meios de como obtê-la; e uma dimensão transcendente, que vincula a realização individual à ordem moral que rege o universo'. / No entanto, encontram-se nela também narrativas em primeira pessoa, histórias de vida, em que o sujeito relata a descoberta de suas forças mais íntimas e a maneira como as empregou para superar seus problemas individuais ou narra como passou por um processo de mudança interior, tornando-se, por conta própria, uma nova pessoa." (RÜDIGER, 1996, p. 143). 
$\mathrm{O}$ juízo sobre a autoajuda como fonte praticamente inesgotável de receitas para a construção de uma personalidade cada vez mais vendável, mesmo quando os fins pretendidos não são pecuniários, foi se consolidando desde a década de 1930 até provocar reações desse tipo nos dias atuais. Para Bosco, como já colocado, isso tem a ver com a imposição de um tipo de racionalidade próprio à esfera produtiva, de trabalho, para o âmbito das relações sociais e afetivas. Para este autor, os manuais refletem a percepção dos problemas como desajustes pessoais para os quais tais textos proviriam soluções de adequação e encaixe. Isso não se altera, segundo o sociólogo, a despeito das mudanças nos rumos editoriais desde então: os instrumentos necessários à realização pessoal permanecem única e exclusivamente no indivíduo ${ }^{44}$.

A discrepância existente entre a noção cristalizada de autoajuda como sinônimo de manual e aquilo que os autores contemporâneos dizem fazer tem a ver com o desenvolvimento daquilo que Anthony Giddens chamou de institucionalização da dúvida e da atitude reflexiva na modernidade tardia ${ }^{45}$. Para este autor, o traço distintivo das chamadas sociedades modernas em relação às tradicionais é a ascensão de um ideal libertário, responsável pelo desprendimento das pessoas em relação a padrões morais supraindividuais. Isso se reflete, inclusive, no status do conhecimento:

A modernidade institucionaliza o princípio da dúvida radical e insiste em que todo conhecimento tome a forma de hipótese - afirmações que bem podem ser verdadeiras, mas que por princípio estão sempre abertas à revisão e podem

\footnotetext{
$44 \operatorname{Bosco}(2001$, p. 18).

45 Giddens (2002, p. 10).
} 
ter que ser, em algum momento, abandonadas. Sistemas de conhecimento acumulado (...) representam múltiplas fontes de autoridade, muitas vezes contestado internamente e divergentes em suas implicações. Nas situações a que chamo de modernidade 'alta' ou 'tardia' - nosso mundo de hoje - o eu, como os contextos institucionais mais amplos em que existe, tem que ser constituído reflexivamente. Mas essa tarefa deve ser realizada em meio a uma enigmática diversidade de opções e possibilidades. (GIDDENS, 2002, p. 11).

Nesse contexto, parece realmente ser pouco plausível que indivíduos que publicam livros aceitem a posição de donos da verdade que lhes é taxada pelos estereótipos associados ao termo autoajuda.

Como já colocado, tomar a autoajuda quase que indiscriminadamente como sinônimo de manual não é prerrogativa apenas de quem é sujeito neste ramo editorial. Muitas vezes, também quem o toma por objeto de reflexão sociológica faz essa associação, até mesmo reafirmando as cores negativas com as quais a ideia do receituário é comumente pintada. Rüdiger, ainda na introdução de seu livro, faz algumas fortes colocações nesse sentido:

A perspectiva em que nos situamos eventualmente carrega aspectos profissionais da personagem caricaturizada (sic) pelo publicista, mas decididamente não se identifica com a figura do contra-escritor que ela refere e, por isso, rejeita com firmeza a sugestão de que a presente pesquisa não só equivale a um 'livro de anti-ajuda' como contém uma refutação performativa das proposições avançadas sobre sua matéria de estudo. Segundo nosso juízo moral, a literatura do gênero, majoritariamente, 'não passa de uma 
forma de charlatanismo, de maneira de se iludir a si mesmo', conforme dizia Max Weber. Por outro lado, concordamos, em tese, com a ideia de que um esclarecimento histórico-filosófico do assunto em foco precisa fugir do 'ressentimento' que, segundo a não obstante má consciência dos pregadores, (às vezes) move seus críticos (RÜDIGER, 1996, p. 27).

Como assunto maldito que se torna, negar a autoajuda parece até mesmo dever ser tarefa de quem estuda este gênero literário considerado menor entre os meios intelectuais ${ }^{46}$. É buscando escapar de armadilhas - inclusive aquela encapsulada em qualquer resposta que eu dê ao questionamento que dá título a este trabalho, já que isso seria aceitar o tipo de busca de satisfação e as soluções que leigos e especialistas esperam encontrar nos volumes catalogados como autoajuda - que venho tentando trabalhar antropologicamente um objeto cercado de menoridade, a despeito de sua ampla circulação em nossa sociedade.

Os desafios dessa pesquisa provocam reflexões sobre o próprio exercício antropológico e sobre fronteiras, transformações e hierarquias constituintes deste campo de conhecimentos. Pensar sobre as exigências extras de legitimidade que meu trabalho parece suscitar é também considerar a própria historicidade de objetos antropológicos: é relativamente recente, por exemplo, a estabilização dos estudos sobre telenovela no campo, eclipsados sobre o guarda-chuva midiático. É, sobretudo, considerar as diferenças e desigualdades internas ao campo que, de certa forma, prestigiam determinadas discussões em detrimento de outras. Entendendo

46 Salem (1992b, p. 2). 
que os marcadores sociais da diferença não perpassam somente a forma como realizamos as nossas análises mas também a posição que ocupamos no campo de pesquisa, como antropólogos, e nos corredores institucionais, como colegas, encerro o texto destacando um elemento de gênero constituinte e determinante da minha inserção acadêmica.

Sou uma jovem pesquisadora voltada para o estudo de um objeto cujas associações com a feminilidade já foram destacadas, tanto para o mercado anglo-saxão ${ }^{47}$ quanto para o cenário nacional ${ }^{48}$. Para Cynthia Schrager, isso se deve à conversão deste campo literário em espaço de discussão de problemas femininos fora de contexto feminista ${ }^{49}$ : aquilo que Hochschild chama de abdução do feminismo ${ }^{50}$. Há que se ponderar, portanto, essa associação quando a minha posição como antropóloga é, de certa forma, questionada por meio de comentários e chistes dirigidos ao meu objeto e aos meus propósitos de pesquisa. Abordagens que talvez não seriam feitas em se tratando de objetos mais tradicionais da disciplina.

47 Hazleden (2003, p. 425).

48 "Em termos quantitativos, na atual realidade brasileira - segundo dados de pesquisa de mercado sobre o perfil do leitor brasileiro - os leitores de auto-ajuda são, em sua maioria, mulheres com mais de quarenta anos de idade, de escolaridade média, e pertencentes às classes B e C. Nos Estados Unidos da América, o mesmo ocorre, pois elas são as grandes consumidoras desta literatura, além de serem muitas vezes consideradas destinatárias das obras" (ALVES, 2005, p. 22).

49 Schrager (1993, p. 177).

50 Hochschild (1994). 


\section{Referências}

ALVES, Vera Lucia Pereira. Receitas para a conjugalidade: uma análise da literatura de auto-ajuda. 2005. 246 f. Tese (Doutorado em Educação). Faculdade de Educação: Universidade Estadual de Campinas: Campinas, 2005.

ARAÚJO, Sílvia Amélia; LUIZ, Vinícius. Tudo o que você quer saber (e mais um pouco): GLOSS ajuda você a descobrir o que pode (e o que, definitivamente, não pode) aprender com os livros de autoajuda. Revista Gloss, São Paulo, n. 56, 2012. p. 196 - 205.

BOSCO, Angelo Marcos. Sucessos que não ocorrem por acaso: literaturas de auto-ajuda. 2001. 94 f. Dissertação (Mestrado em Sociologia). Instituto de Filosofia e Ciências Humanas, Universidade Estadual de Campinas: Campinas, 2001.

CASTRO, Talita. Auto-ajuda e a reificação da crise da meia-idade. 2009. 214 f. Dissertação (Mestrado em Antropologia Social). Instituto de Filosofia e Ciências Humanas: Universidade Estadual de Campinas: Campinas, 2009.

FERGUSON, Will. Ser feliz ${ }^{\circledast}$. 2.ed. Trad.: Manoel Paulo Ferreira. São Paulo: Companhia das Letras, 2003. 397 p.

FRANCO, Andrea. 40 sim! E daí? Um guia de qualidade de vida para as mulheres depois dos 40 anos. São Paulo: Idéia\&Ação/ Matrix, 2008. 221 p. 
GIDDENS, Anthony. A transformação da intimidade: sexualidade, amor \& erotismo nas sociedades modernas. Trad.: Magda Lopes. São Paulo: Editora da Unesp, 1993. 228 p.

. Modernidade e identidade. Trad.: Plínio Dentzein. Rio de Janeiro: Zahar Editor, 2002. 233 p.

HAZLEDEN, Rebecca. Love yourself: the relationships of the self with itself in popular self-help books. Journal of sociology. Melbourne, v. 4, n. 39, p. 413 - 428, 2003.

HOCHSCHILD, A. R.; TANAKA, Kazuko. Light and heavy: american and japanese advice books for women. In: HOCHSCHILD, A. $R$. The commercialization of intimate life: notes from home and work. Berkley. Los Angeles \& Londres: The University of California Press, p.58-72.2003.

HOCHSCHILD, A. R.; TANAKA, Kazuko. Light and heavy: american and japanese advice books for women. In: HOCHSCHILD, A. $R$. The commercialization of intimate life: notes from home and work. Berkley. Los Angeles \& Londres: The University of California Press, 2003. p. $58-72$.

LAURENTINO, André. Livros de autoajuda: como largar este vício. In: LEITE, Ivana Arruda (org.). 35 segredos para chegar a lugar nenhum: literatura de baixo-ajuda. Rio de Janeiro: Bertrand Brasil, p.29-32. 2007.

LEMOS, Regina. Quarenta: a idade da loba. 11. ed. São Paulo: Globo, 1996.320 p. 
PAPALINI, Vanina. 2009. Silenciar el cuerpo: paliativos para las nuevas modalidades de relación y de producción. In: CONGRESSO ASSOCIAÇÃO LATINO-AMERICANA DE SOCIOLOGIA, 27, 2009, Buenos Aires. Anais... Buenos Aires: Associação LatinoAmericana de Sociologia, 2009. CD-ROM.

PARREIRAS, Carolina. Não leve o virtual tão a sério? Uma breve reflexão sobre os métodos e convenções na realização de uma etnografia do e no on-line. In: CUNHA, Flávia M.; DULLEY, Iracema; FERIANI, Daniela M. (orgs.). Etnografia, etnografias: ensaios sobre a diversidade do fazer antropológico. São Paulo: Annablume/ FAPESP, p. 43-61.2011.

RÜDIGER, Francisco. Literatura de auto-ajuda e individualismo: contribuição ao estudo da subjetividade na cultura de massa contemporânea. Porto Alegre: Editora da Universidade Federal do Rio Grande do Sul, 1996. 295 p.

SALEM, Tania. A despossessão subjetiva: dos paradoxos do individualismo. Revista Brasileira de Ciências Sociais, São Paulo, v.7, n.18, p.62-77, 1992a.

. Manuais modernos de auto-ajuda: uma análise antropológica sobre a noção de pessoa e suas perturbações. Rio de Janeiro: Universidade Estadual do Rio de Janeiro: Instituto de Medicina Social, 1992b. 36 p. (Série Estudos em Saúde Coletiva, v.7).

SCHRAGER, Cynthia D. Questioning the Promise of Self-Help: a Reading of Women Who Love Too Much. Feminist Studies, College Park, v. 1, n. 19, p. 177 - 192, 1993. 
SLENES, Robert W. Esperanças e recordações: condições de cativeiro, cultura centro-africana e estratégias familiares. In: . Na senzala, uma flor: esperanças e recordações na formação da família escrava: Brasil, Sudeste, século XIX. Rio de Janeiro: Nova Fronteira, p.131-197. 1999. 


\section{Imagens juvenis no cinema brasileiro contemporâneo}

Janie k. Pacheco

\section{O cinema como expressão da cultura juvenil}

Em seus primórdios, o que despertava a curiosidade das pessoas acerca do cinema era sua capacidade de "reproduzir", de forma quase perfeita, as imagens do mundo real. As técnicas de reprodução do final do século XIX, da fotografia ao fonógrafo e ao cinematógrafo, perseguiam, assinala o crítico francês André Bazin, o realismo integral (MERTEN, 2007). Imaginava-se que "a vida (poderia ser reproduzida) tal como ela era", mas, "na verdade, não é bem assim, e as modernas teorias dos autores deixam claro que o que vemos na tela é menos o mundo que a visão do mundo pelos artistas" (MERTEN, 2007, p.16).

Tais ponderações podem ser encaminhadas à constituição de certas imagens ou representações acerca da juventude fixadas no/ pelo cinema. É consenso entre estudiosos que a juventude é uma categoria social erigida sobre uma faixa etária surgida na sociedade moderna ocidental, sendo, portanto, uma construção socio-histórica particular (LEVI; SCHMITT, 1996; GROPPO, 2000; 
ABRAMO, 2005; VELOSO, 2009; SAINTOUT, 2009). Como pondera Enne (2010), se a juventude é essa categoria social que emerge no processo de constituição da modernidade ocidental, apenas nas primeiras décadas do século XX, este jovem se torna sujeito objetivado em vista desse recorte etário e da sua confluência com o consumo e a mídia.

Seria incorreto, em vista dessas premissas, desconsiderar o quanto essa categoria, a juventude, tem sido construída pelos meios midiáticos (tanto impressos quanto eletrônicos) com mais intensidade a partir da década de 1950 (MIRA, 2001; FREIRE FILHO, 2008). Convém assinalarmos também que ascensão da música popular, em especial o rock, desempenha um papel igualmente notável para a constituição dessa categoria social (CARMO, 2001; BRANDÃO; DUARTE, 2004).

Gradualmente, valores, comportamentos, bens materiais e simbólicos passam a fazer parte de uma cultura juvenil, como apontam Sarlo (2000), Carmo (2001) e Borelli; Rocha; Oliveira (2009). E nesse sentido, o cinema constitui-se uma referência ímpar na constituição das culturas juvenis, sobretudo com a cinematografia norte-americana ${ }^{51}$. Quem assiste nos dias de hoje a Juventude transviada (1955), filme estrelado por James Dean, Natalie Wood e Sal Mineo, pode não perceber transgressão e rebeldia, mas, naquele contexto, assinalam Borelli; Rocha; Oliveira (2009, p.114):

$[\ldots]$ a calça justa e a jaqueta vermelha diziam
que os jovens não queriam mais se vestir com o
mesmo terno e gravata dos adultos, e o automóvel
passava a ser o principal aliado nas suas andanças

51 Lembramos que, neste período, década de 1950, a linguagem cinematográfica estava consolidada e ao aparato tecnológico que viabiliza o cinema já estava incorporado o som e a fotografia em cores (MERTEN, 2007). 
pela cidade. $O$ filme trazia a emergência das buscas de afirmação da inserção juvenil no mundo e da cultura do risco: os "rachas" de carro e o uso do revólver colocavam o "matar ou morrer" como as únicas saídas para as disputas cotidianas. (BORELLI; ROCHA; OLIVEIRA, 2009, p. 114).

Num período curto de tempo, outros filmes tematizaram tanto a "rebeldia", a "transgressão" quanto a "delinquência" juvenil, como O selvagem (1954), Sementes da violência (1955), O prisioneiro do rock (1955) e Ao balanço das horas (1956)..$^{52}$ Além disso, a música, a dança e, consequentemente, os novos comportamentos sugeridos se tornam elementos vitais nessas narrativas juvenis, assinala Bueno (2005).

Os novos modelos de comportamento social evidenciados pelo cinema sinalizam as mudanças que se processam no pós-guerra, como afirmam Borelli; Rocha; Oliveira (2009), cujos efeitos mais notáveis relacionados à liberalização dos costumes se processam na década de 1960, na perspectiva de Hobsbawn (1995). Como nos lembra Groppo (2000), há também a importância recíproca de juventude, lazer e cultura de massa, uma vez que lazer e diversão passaram a identificar juvenilidade. Morin (1984) é um dos primeiros a apontar a juvenilidade como um elemento altamente expressivo da composição das "mitologias modernas" da cultura de massa que neste momento ganha corpo.

52 Contudo, a produção de filmes voltados ao segmento juvenil, sobretudo garotos adolescentes, já existia desde os anos 1940 nos Estados Unidos, eram os quickies, assim denominados por serem de baixo orçamento e de rápida produção. Na década seguinte, ganham força os teenpictures, ou teenpics, filmes que "abordavam o sexo, atrocidades e monstruosidades, bem como assuntos oportunos e controversos envolvendo a juventude dos anos 50 e 60" (BUENO, 2005, p. 26). 


\section{O jovem no cinema nacional}

Bueno (2005, p.30) afirma que a "sinergia entre as indústrias musicais e cinematográficas detectadas no contexto norte-americano se reproduziu em outros mercados, como o brasileiro", embora não com a mesma desenvoltura e com certos descompassos. O primeiro filme nacional no qual o rock se faz presente chama-se $D e$ vento em popa (1957), é estrelado por Oscarito, ator símbolo das chanchadas da Atlântida. De jaqueta de couro e brilhantina nos cabelos, ele faz uma paródia ao cantor-sensação daquele momento: Elvis Presley. Outros filmes se seguiram associando rock e juventude, sobretudo na década de 1960, estrelados pelos cantores Jerry Adriani, Roberto Carlos e Antônio Carlos.

Nessa mesma década, a proposta estética e política do Cinema Novo, encabeçada por Glauber Rocha, assinalava outro caminho. "A juventude no Cinema Novo", afirma Bueno (2005, p.57), "se associava a uma perspectiva de redescoberta e renascimento, muitas vezes relacionada ao redescobrimento do espaço de atuação desse jovem, espaço este visto como território da nação". Dessa forma, o jovem retratado em seu contexto urbano e familiar, "era o agente político revolucionário inserido na estrutura global das transformações sociais". Além do Cinema Novo, frisa a autora, o Cinema Marginal também problematizou, a partir de sua produção e estética, "a transformação do país em uma nação moderna" (2005, p. 59). Esta vertente inclusive seria responsável pela renovação da cinematografia nacional voltada para o entretenimento, traço este que marca as produções voltadas ao público juvenil, em vista da linguagem mais anárquica e provocadora adotada, constatada em Roberto Carlos em ritmo de aventura (1968) e nos demais filmes protagonizados pelo "rei" Roberto Carlos e dirigidos por Roberto Faria. 
A década de 1970 registra títulos que direcionam apelos eróticos tanto para os jovens quanto para os espectadores de pornochanchadas, tipo de filme que se tornou marca registrada do período. O sucesso do filme Embalos de sábado à noite (1977), estrelado por John Travolta, fez com que programas televisivos e filmes voltados aos jovens utilizassem quase de forma obrigatória as palavras "ritmo", "embalo" e "alucinante", como é possível notar nos títulos Sábado alucinante e Nos embalos de Ipanema, ambos de 1979 (BUENO, 2005).

Títulos significativos voltados aos jovens vão ser encontrados, na década de 1980, em vista da dinâmica do campo cinematográfico associado à indústria editorial, presente nas adaptações das autobiografias homônimas Feliz ano velho, de Marcelo Rubens Paiva, e Com licença, eu vou à luta, de Eliane Maciel; ou à indústria fonográfica nos "filmes de praia", Menino do Rio e Garota Dourada, ou ainda Bete Balanço e Rock estrela (BUENO, 2005) ${ }^{53}$.

No entanto, na década seguinte, a produção fílmica no país é fortemente abalada pelas medidas do Presidente Fernando Collor de Mello, que veio a extinguir de órgãos culturais, como a Empresa Brasileira de Filmes S.A. (Embrafilme), que, embora com dificuldades, era o que sustentava o cinema brasileiro. Para se ter ideia do impacto dessa "política cultural", em 1992, apenas dois filmes de longa-metragem foram lançados no Brasil (NAGIB, 2002). Dentre os raríssimos títulos da década que tematizam a juventude estão: Não quero falar sobre isto agora (1991), Murilo Salles; A ostra e o vento (1997), Walter Lima Jr e Como ser solteiro (1998), Rosane

53 Convém assinalar a produção cinematográfica proveniente do Rio Grande do Sul, “fora do eixo" Rio-São Paulo, na década de 1980, que, guardadas proporções com a produção nacional, é significativa, conforme assinala Seligman (2001 apud BUENO, 2005). 
Svartman. Passado esse período de turbulência, assinala Autran (2009), uma nova legislação, calcada na renúncia fiscal, revitaliza a produção cinematográfica através da Lei do Audiovisual.

\section{Diferença e desigualdade nas imagens juvenis no cinema nacional}

A diversidade temática e estética na produção cinematográfica, na primeira década do século XXI, é notável. Como assinala Eduardo (2011, p.14), ao fazer um balanço desse período: os filmes nacionais ambicionam ser representativos de "um estado de coisas do país em nosso tempo". Tal direcionamento, como o próprio autor assinala, contudo, não é novidade no cinema nacional:

Desde antes do Cinema Novo, nos anos 1960, havia uma reivindicação de olhar para nossa realidade, não apenas para recolher uma justa aparência para nossas paisagens, mas também para lidar com traços de síntese das noções de país. Se não síntese, ao menos enfoques que, apesar de se dirigirem a algo específico (ao sertão, à classe média, à favela, ao analfabetismo, à imigração), não bastam em si mesmos. (EDUARDO, 2011, p. 14).

Tal diversidade, ainda que de forma menos intensa, é percebida nos filmes que têm o jovem como protagonista. No período de 2000 a 2006, é possível contabilizar, segundo Rego (2009), 17 títulos. Em levantamento para o estudo que realizamos, contabilizamos até o presente momento mais 17 películas com essa característica produzidas entre 2007-2011.

Todavia, em que pese a existência desses filmes, o diagnóstico efetuado por Freire Filho (2008, p. 43) é muito revelador: "Em 
contraste com a representação relativamente escassa da adolescência e da juventude no cinema nacional, a abordagem do tema pela nossa mídia impressa é profusa e instigante, multiplicando-se pelas mais variadas seções”. Isto é, o cinema (in) forma "menos" sobre o jovem/ juventude no que tange a processos de subjetivação do que a mídia impressa põe em marcha ${ }^{54}$. Rocha e Pereira (2009) corroboram essa perspectiva ao afirmarem que esta tendência midiática, sobretudo, em matérias jornalísticas, oportuniza tanto a constituição de estereótipos quanto a constituição de um imaginário multifacetado acerca da adolescência/juventude.

Tendo em mente esses aspectos, podemos nos debruçar sobre seis filmes que tematizam o jovem/juventude e/ou adolescente/ adolescência. A composição desse corpus visa tão-somente, no presente momento, a tecer algumas considerações preliminares acerca das representações dessa categoria no cinema. A seleção das obras efetuou-se em vista do destaque obtido junto à crítica especializada, embora isto nem sempre tenha se convertido em boas cifras de bilheteria. Os filmes selecionados foram incluídos em três categorias orientadas pela seguinte questão: quais são os tipos de jovens que aparecem no cinema brasileiro contemporâneo? Apresentamos a seguir a sinopse dos filmes selecionados e a correspondente categoria na qual foram alocados para que possamos seguir na exposição pretendida.

Os filmes Cidade de Deus (2002), de Fernando Meireles e Kátia Lund, e Sonhos roubados, de Sandra Werneck (2009), compõem a primeira categoria intitulada Juventude à beira do desvio.

54 Em pesquisa bibliográfica conduzida para a realização desta pesquisa, foram localizadas até o presente momento somente a tese de Bueno (2005) e a dissertação de mestrado de Rego (2009), ambas voltadas à temática do jovem no cinema nacional. 
Cidade de Deus é o filme que assinala o período chamado de pós-retomada do cinema brasileiro ${ }^{55}$. Embora com ressalvas em vista de uma possível estetização da pobreza e da violência, a crítica especializada assevera que nenhum filme causa tanto impacto no início dos anos 2000 quanto a adaptação do romance homônimo de Paulo Lins ${ }^{56}$. Houve detratores e defensores apaixonados do filme. Resumidamente, a narrativa trata das mudanças operadas no tráfico de drogas, dos anos 1960 aos 1980, e a gradativa substituição da maconha pela cocaína na Cidade de Deus, condomínio habitacional popular na zona oeste da cidade do Rio de Janeiro. Sob a ótica de Buscapé, morador local, que, apesar da "pressão do meio" não se envolve com o tráfico, somos conduzidos aos meandros desse submundo e aos seus principais personagens (Zé Pequeno, Cenoura, Bené, Mané Galinha), bem como as alianças e disputas que realizam.

Sonhos roubados conta a vida de três jovens moradoras de uma favela carioca. Jéssica tem um filho pequeno. Como não dispõe de recursos próprios para criar o filho, sozinha, necessita, com relativa frequência, contar com o auxílio de outras pessoas (o avô materno, o ex-namorado e a mãe deste, que é evangélica) para isto. Para fazer frente à "dureza da vida", aceita se passar por esposa de

55 Esta obra, para os especialistas do campo cinematográfico, marca tanto o fim do "cinema da retomada" (cujo marco é Carlota Joaquina realizado em 1995), quanto o início do "cinema da pós-retomada", que perdura até o presente momento.

56 Para o crítico Luiz Zanin Oricchio (2003, p.160), “[...] não há dúvida que Cidade de Deus é o filme que articula por completo a linguagem contemporânea do cinema e da sociedade", retornando de maneira consistente a alguns ambientes do cinema nacional, como o sertão e a favela. O primeiro, na visão do autor, "é tratado em filmes em geral despolitizados, o que é uma marca do nosso tempo. Já a favela é vista de maneira mais rica e também menos idealizada em relação ao que foi nos anos 50 e 60. Retrata-se nela o que há de problemático, mas também de criativo” (Id, 2003, p.160). 
um presidiário mediante pagamento em dinheiro. Sabrina é a única a ter uma ocupação que lhe fornece algum ganho, embora precário: é atendente de uma lanchonete. Todavia ela é demitida no início do filme, pois costuma não cobrar pelos lanches que serve. Após a demissão, envolve-se com um traficante. Daiane, a mais jovem das três, mora na casa da tia materna, onde é constantemente assediada pelo tio. Ela busca estabelecer vínculos afetivos com o pai, que mora na mesma favela. Todavia ele não a reconhece como filha. Esporadicamente, prostitui-se. No decorrer do filme, estabelece uma relação de amizade com a dona de um salão de beleza no qual vem a trabalhar como cabeleireira.

Cidade de Deus tem, no tráfico de drogas, o fio condutor da narrativa, já em Sonhos roubados a prostituição é deflagrada em vista de situações a partir das quais a premência das condições objetivas impede ou dificulta a realização de projetos de vida. Não à toa os atores que dão vida aos personagens são em sua maioria negros e mantêm ocupações precárias através das quais buscam obter seu sustento.

Além disso, a família e a escola inexistem ou se mostram pouco presentes na condução dessas histórias. Em Cidade dos homens inexistem arranjos familiares ou situações que remetam ao espaço escolar. Já em Sonhos roubados Jéssica e o filho pequeno residem com o avô materno e Daiane mora com os tios maternos. Nas situações dramatizadas desses filmes, a família perde sua força como ordem simbólica, na acepção de Sarti (2004, p.13), ou seja, como uma "realidade constituída pela linguagem, socialmente elaborada e internalizada pelos indivíduos (que se torna), um campo privilegiado para se pensar a relação entre o individual e o coletivo, portanto, entre mim e o outro".

Destacamos também que nesses dois filmes não há cenas que se passem na escola, mas situações que remetem à mesma. Podemos 
aqui ponderar o que esta ausência revela acerca dos membros das classes menos favorecidas: "presos à presença do mundo, ou seja, à necessidade, percebem, vagamente, oportunidades de elevação social pela via escolar" (PEREIRA; CATANI, 2002, p. 112).

Os filmes Meu nome não é Johnny (2008), de Mauro Lima, e Bruna Surfistinha (2010), de Marcos Baldini, compõem a segunda categoria intitulada heróis tortos. $\mathrm{O}$ primeiro traz a ascensão e queda de um jovem como traficante e o segundo narra as experiências de uma jovem que se torna garota de programa. Primeiramente chama a atenção que as duas narrativas enfocam personagens midiatizados por suas subversões de conduta antes de virarem tema de filmes. Em segundo lugar, os dois protagonistas são jovens de classes médias urbanas, destoando significativamente da origem social dos protagonistas da categoria anterior ${ }^{57}$. Apesar do investimento dos pais na formação dos filhos, em especial na obtenção de um capital cultural (no sentido atribuído por BOURDIEU, 2007), visualizamos em suas vidas uma conduta desviante (no sentido dado por BECKER, 2008). Em Meu nome não é Johnny, João se torna traficante de cocaína; e em Bruna Surfistinha, Raquel envereda para a prostituição, adotando o nome que a tornaria famosa nacionalmente.

Podemos visualizar duas distintas formas de redenção para esses protagonistas: em $\mathrm{Meu}$ nome não é Johnny, o protagonista abandona a "vida de traficante" (afinal vendia droga para comprar para si), não sem antes ficar trancafiado num manicômio judiciário; e Bruna Surfistinha deixa a prostituição, não sem enfrentar o descenso profissional (e moral): deixa de ser uma garota de programa

57 Especulamos se esta combinação, histórias reais e protagonistas "desviantes" de classe média, associada a uma narrativa ágil com dosagem moderada de violência física e/ou cenas de sexo não explícitas tenha contribuído para o êxito comercial desses filmes: somados, o número de espectadores chega a mais de 7 milhões (ANCINE, 2011). 
que possui um blog e tem agenda lotada de clientes e se torna uma prostituta. É este blog no qual descreve suas experiências como Bruna Surfistinha que posteriormente foi convertido em livro e se tornou um best-seller.

A família e a escola aparecem timidamente nesses dois filmes. A vida em família de João, que é filho único, sobressai-se no período da infância. Já as situações vivenciadas por Raquel sugerem alguém que se encontra fora de lugar: nem a família nem a escola contribuem para que possa se constituir como sujeito.

As melhores coisas do mundo (2010), de Laís Bodanski; e Desenrola (2011), de Rosane Svartman, constituem a terceira e última categoria chamada filmes para adolescentes. Destacamos que o chamariz publicitário dessas duas produções estava centrado justamente nisto, ou seja, filmes voltados ao público adolescente ${ }^{58}$.

As melhores coisas do mundo retrata a adolescência de Mano (Hermano): a primeira experiência sexual, a vida na escola, o primeiro amor, preconceito e dramas familiares (por conta da separação dos pais e da tentativa de suicídio de Pedro, irmão mais velho). Já a trama de Desenrola está centrada na "primeira vez" de Priscila, situação antecipada em vista da viagem a trabalho que sua mãe terá de realizar, oportunizando que ela fique sozinha em casa.

A presença constante de dois agentes socializadores chama a atenção nos filmes pertencentes a essa categoria: a família e a escola. Nessas circunstâncias, a família se afirma como ordem simbólica, sendo fundamental para o processo de subjetivação dos protagonistas dessas histórias (SARTI, 2004). E aqui ressaltamos que os

58 Entendemos que a estratégia de lançamento dessas produções mostrou-se coerente com o público jovem que constituiu a parcela significativa das salas de cinema do país (localizadas, sobretudo, em shopping centers), conforme menciona Autran (2009). O desempenho de bilheteria foi considerado razoável: cada filme conseguiu atrair quase 300 mil espectadores aos cinemas (ANCINE, 2011). 
arranjos familiares mostrados são distintos, mas o papel que a família cumpre nesses filmes contrasta fortemente com os filmes que compõem a primeira categoria: em As melhores coisas do mundo, Mano depara-se com a separação dos pais e faz uma descoberta: o pai é gay e tem um namorado; e em Desenrola, os pais de Priscila são separados, ela vive com a mãe e o pai tem uma nova esposa e uma filha pequena.

O papel da instituição escolar, por sua vez, nessas produções vem ao encontro das formulações de Abramo (2005) acerca da juventude na sociedade contemporânea. Para a autora, esta categoria caracteriza-se como uma segunda socialização necessária "para a complexidade das tarefas de produção e a sofisticação das relações sociais que a sociedade industrial trouxe” (2005, p. 41). Esta preparação é realizada pela escola, o que implica a "suspensão do mundo produtivo (e da permissão de reprodução e participação); estas duas situações (ficar livre das obrigações do trabalho e dedicado ao estudo numa instituição escolar) se tornaram os elementos centrais de tal condição juvenil” (2005, p. 41).

O significado social que isso abarca é que a compreensão da juventude como um período de transição, ou de uma "moratória", para utilizar a expressão de Erik Erikson (1986 apud ABRAMO, 2005, p.41), uma vez que compreenderia "esse adiamento dos deveres e direitos de produção, reprodução e participação, um tempo socialmente legitimado para a dedicação exclusiva à formação para o exercício futuro dessas dimensões da cidadania”. Não à toa, acontecimentos importantes para o andamento e desfecho das narrativas que envolvem os personagens centrais têm como cenário a escola. Além disso, nenhum dos personagens exerce ou está preocupado em exercer alguma atividade/ocupação que lhe garanta o seu sustento ou forneça algum tipo de ganho regular. 
Podemos afirmar que nos filmes que compõem a primeira categoria a juventude dos personagens não tem visibilidade, de alguma forma, ela "desaparece" em meio às situações de violência deflagradas pelo tráfico de drogas e/ou pela vulnerabilidade social na qual se encontram os personagens. Como assinala Novaes ([s.d.], p.1), sendo a sociedade brasileira marcada por "grandes distâncias sociais, são desiguais e diferentes as possibilidades de se viver a juventude como uma moratória, como tempo de preparação" ${ }^{\text {99 }}$.

Correndo o risco de cometer algum exagero, nos filmes que compõem a segunda categoria se evidencia uma ideia romantizada de juventude dada a sua recusa em "obedecer" às regras da sociedade (ou às regras do mundo adulto): João e Raquel, cada um a seu modo, são heróis hedonistas, oferecem prazer e buscam o prazer.

E quanto à terceira categoria, a ênfase recai nas descobertas, experiências e projetos de vida dos protagonistas, Mano e Priscila, para os quais tanto a família quanto a escola desempenham papel fundamental. Aliás, a existência de projetos de vida para eles é indissociável de um pensamento prospectivo, ou seja, a visão de que o futuro (e o que ele trará) é mais importante do que o presente.

\section{Considerações finais}

Estas reflexões preliminares acerca das representações do jovem no cinema brasileiro deste novo século nos sugerem não apenas características culturais distintas, mas desigualdades sociais marcantes. Tal como aponta Novaes ( $\mathrm{s} / \mathrm{d}$ ), ao expor suas ponderações sobre a juventude contemporânea, a vivência da condição

59 Não sem razão, das inúmeras críticas recebidas pelo filme poucas delas mencionam a presença de jovens, a atenção centrava-se na pobreza, no tráfico de drogas e nas ações de violência deflagradas por conta das disputas entre os traficantes. 
juvenil está estreitamente associada à origem social, aos níveis de renda, às disparidades entre o campo e a cidade e entre regióes de um mesmo país. Tais disparidades se evidenciam nas formas dessa vivência juvenil, seja em bairros de classe média de cidades como São Paulo ou Rio de Janeiro, seja na periferia desta última.

Como a vivência dessa condição juvenil é diversa - e muitas vezes desigual - não só as temáticas abordadas nesses filmes são diversas: violência e criminalidade associadas ao tráfico de drogas, prostituição, dificuldade de convívio social, iniciação sexual, relacionamento amoroso, mas também as composições das imagens sobre essa condição.

Metz (1980) assinala que o cinema produz uma impressão do real. A natureza imaginativa daquilo que o cinema pode vir a significar é o que o torna um manancial (quase) inesgotável de projeções e emoções. O cinema mostra aquilo que está mais próximo do real, embora não seja a própria realidade. Trazendo essas premissas para os filmes que compõem o corpus dessas reflexões, os filmes incluídos nas categorias juventude à beira do desvio e heróis tortos nos fornecem imagens juvenis marcadas pela intensidade dramática das histórias a serem narradas, norteadas por determinados princípios narrativos e estéticos. Tais princípios nos oferecem imagens nas quais a impressão do real que cerca esses jovens é intensa, cruel, violenta. Já na categoria filmes para adolescentes a impressão do real produzida é distinta, aberta, lúdica, é como se ambos os filmes fornecessem possibilidades para os jovens viverem a vida, realizarem descobertas acerca de si e dos outros.

Por fim, mas não menos importante, cabe assinalar que a sinergia entre a indústria editorial e a cinematográfica inaugurada, na década de 1980, mantém-se profícua, pois à exceção de Desenrola, os demais filmes analisados são adaptações de histórias ficcionais (Cidade de Deus e As melhores coisas do mundo), biografias que se 
tornaram best-sellers (Bruna Surfistinha e Meu nome não é Johnny) ou ainda reportagens sobre as vicissitudes de jovens pobres (Sonhos roubados).

\section{Referências}

ABRAMO, Helena. Condição juvenil no Brasil contemporâneo. In: ABRAMO, Helena W.; BRANCO, Pedro Paulo M. (orgs.). Retratos da juventude brasileira: análises de uma pesquisa nacional. São Paulo: Instituto Cidadania: Editora Fundação Perseu Abramo, 2005.

AGÊNCIA Nacional de Cinema - ANCINE, Disponível em: $<$ http://www.ancine.br> Acesso em: dez. 2011.

AUTRAN, Arthur. O cinema brasileiro contemporâneo diante do público e do mercado exibidor. Significação, São Paulo, n.32, 2009.

BECKER, Howard. Outsiders: estudos de sociologia do desvio. Rio de Janeiro: Jorge Zahar, 2008.

BORELLI, Sílvia H.S.; ROCHA, Rose de M.; OLIVEIRA, Rita de Cássia (coord.). Jovens na cena metropolitana: percepções, narrativas e modos de comunicação. São Paulo: Paulinas, 2009.

BOURDIEU, Pierre. A distinção: crítica social do julgamento. São Paulo: Edusp: Porto Alegre: Zouk, 2007.

BRANDÃO, Antonio Carlos; DUARTE, Milton Fernandes. Movimentos culturais de juventude. São Paulo: Moderna, 2004. 
BUENO, Zuleika de P. Leia o livro, veja o filme, compre o disco: a produção cinematográfica juvenil brasileira na década de 1980. Tese (Doutorado em Multimeios), Universidade Estadual de Campinas: Instituto de Artes, 2005.

CARMO, Paulo Sérgio do. Culturas da rebeldia: a juventude em questão. : São Paulo: Editora SENAC, 2001.

DAYRELL, Juarez. O jovem como sujeito social. Revista Brasileira de Educação, n.24, set/dez, 2003.

EDUARDO, Cléber. Que país é este? In: CINEMA BRASILEIRO - anos 2000, 10 questões. Rio de Janeiro: Centro Cultural Banco do Brasil, [2011]. p.14. Disponível em: <http://www.bb.com.br/docs/ $\mathrm{pub} /$ inst/img/CatalogoCinemaBras.pdf $>$

. Para onde vão nossos heróis? In: CINEMA BRASILEIRO - anos 2000, 10 questões. Rio de Janeiro: Centro Cultural Banco do Brasil, [2011]. p.20. Disponível em: <http://www.bb.com.br/docs/ pub/inst/img/CatalogoCinemaBras.pdf $>$.

ENNE, Ana Lúcia. Juventude como espírito do tempo, faixa etária e estilo de vida: processos constitutivos de uma categoria-chave da modernidade. Comunicação, mídia e consumo. São Paulo, v. 7, n.20, nov. 2010.

FREIRE FILHO, João. Retratos midiáticos da nova geração e a regulação do prazer juvenil. In: BORELLI, Silvia H.S.; FREIRE FILHO, João (orgs). Culturas juvenis no século XXI. São Paulo: Educ, 2008. 
GROPPO, Luís Antonio. Juventude: ensaios sobre sociologia e história das juventudes modernas. Rio de Janeiro: Difel, 2000.

HOBSBAWN, Eric. A revolução cultural. In: . A era dos extremos. São Paulo: Companhia das Letras, 1995.

LEVI, Giovanni; SCHMITT, Jean-Claude (orgs.). História dos jovens. São Paulo: Companhia das Letras, 1996.

MERTEN, Luiz Carlos. Cinema: entre a realidade e o artifício. 2.ed. Porto Alegre: Artes e Ofícios, 2007.

MIRA, Maria Celeste. O leitor e a banca de revistas. São Paulo: Olho d'água, 2001.

MORIN, Edgar. Cultura de massa no século XX: o espírito do tempo. 6.ed. Rio de Janeiro: Forense Universitária, 1984. (Coleção Neurose, v.1).

NAGIB, Lucia. O cinema da retomada: depoimentos de 90 cineastas dos anos 90. São Paulo: Editora 34, 2002.

NOVAES, Regina. Juventude e sociedade: jogos de espelhos, sentimentos, percepções e demandas por direitos e políticas públicas. [s.d.].

ORICCHIO, Luiz Z. Cinema de novo: um balanço crítico da retomada. São Paulo: Estação Liberdade, 2003. 
PEREIRA, Gilson; CATTANI, Afrânio. Espaço social e espaço simbólico: introdução a uma topologia social. Perspectiva, Florianópolis, v.20, n. Especial, jul./dez. 2002.

RÊGO, Isabel Almeida M. do. A cultura jovem contemporânea presente na sinergia de linguagens do cinema brasileiro. Dissertação (Mestrado em Comunicação), Programa de Pós-Graduação: Faculdade de Comunicação Social: Pontifícia Universidade Católica do Rio Grande do Sul, 2009.

ROCHA, Everardo; PEREIRA, Claudia. Juventude e consumo: um estudo sobre a comunicação na cultura contemporânea. Rio de Janeiro: Mauad X, 2009.

SAINTOUT, Florencia. Jóvenes: el futuro llego hace rato: percepciones de um tiempo de cambios: família, escuela, trabajo y política. Buenos Aires: Prometeo Libros, 2009.

SARLO, Beatriz. Cenas da vida pós-moderna: intelectuais, arte e videocultura na Argentina. Rio de Janeiro: UFRJ, 2000.

SARTI, Cynthia A. A família como ordem da simbólica. Psicologia USP, v.15, n.3, 2004.

VELOSO, Letícia. Breve revisão sobre a sociologia da juventude. 2009. (mimeo). 


\section{High school cinematográfica: juventude, consumo e popularidade nos filmes de John Hughes}

César Cundari da Rocha Santos

Lennita Oliveira Ruggi

Marcelo Francisco

\section{"É infantil e estúpido, mas a escola também é": cinema high school nos anos 80:}

(3’12) Ferris Bueller: "Como poderia suportar a escola num dia como este? É meu $9^{\circ}$ dia doente este semestre. É duro inventar doenças novas. Se houver o $10^{\circ}$ terei de vomitar, ou não dará mais certo. Para enganar os pais basta umedecer as mãos. Não é um sintoma específico. Creio muito nisso. Dizem que a melhor saída é a falsa febre, mas... se tiver mãe nervosa, pode ir parar num consultório médico. Isso é pior que escola. Finja dor de estômago e quando curvar-se, chore e lamba as mãos. É infantil e estúpido, mas a escola também é. A vida passa muito depressa. Se não 
pararmos para curti-la, podemos perdê-la. Tenho mesmo uma prova hoje. Não era conversa fiada. Sobre Socialismo Europeu. Quer dizer: para quê isso? Não sou europeu, nem pretendo ser. Então, quem liga se são socialistas? Podiam ser anarquistas, fascistas, isto não muda o fato de eu não ter um carro" (Curtindo a vida adoidado, Hughes, EUA, 1986. - grifos do autor).

Tal como anunciado pela previsão do tempo no rádio-despertador, "um dia como esse" significa temperaturas acima de $21^{\circ}$ em Chicago. Após convencer seus pais de um pretenso mal-estar para não ir à aula, o protagonista do filme Curtindo a vida adoidado, Ferris Bueller, explica diretamente ao público as melhores formas para aplicar um golpe bem sucedido. Nada tão dramático que implique uma visita médica, mas grave o suficiente para evitar uma avaliação sobre socialismo europeu. Se a vida passa depressa, algo infantil e estúpido como a escola é perda de tempo. $\mathrm{O}$ interesse de Ferris está voltado para questões muito mais importantes, como o carro que almeja ganhar de presente.

Sendo o processo de escolarização retratado como algo desinteressante, faz sentido que o cinema high school tenha se pautado preferencialmente nos relacionamentos, nas amizades e na curtição: onde a vida de verdade acontece. Tal como caricaturada nos filmes mainstream do gênero, a sociabilidade juvenil sedimenta representações sobre alunos e alunas, professores e professoras, mães e pais - sinalizando a existência de um processo de enunciação compartilhado que privilegia as relações pessoais no ambiente escolar e tem implicações relevantes para o imaginário contemporâneo sobre educação. A proposta deste artigo é investigar tal imaginário, mapeando questões relativas à classe social e gênero em algumas das principais produções dos anos 1980. Serão foco de 
análise: relações com a escola e relações na escola, padrões de consumo, confrontos geracionais e sexualidade.

Parte de um projeto mais amplo que pesquisa as representações sobre educação na mídia de entretenimento ${ }^{60}$, nossa intenção é indicar chaves de leitura para seis filmes escritos, dirigidos e/ou produzidos por John Hughes na década de 1980: Gatinhas e gatões (1984), Clube dos cinco (1985), Mulher nota mil (1985), Curtindo a vida adoidado (1986), Garota de rosa-shocking (1986) e Alguém muito especial (1987).

Em meio a uma reinvenção do cinema norte-americano, contrapondo-se ao sucesso dos concorrentes europeus (BISKIND, 2009), Hughes pode ser enquadrado como um visionário cujos filmes tinham um público-alvo bem específico: os/as adolescentes. As películas por ele produzidas jamais davam prejuízo, tinham um custo extremamente baixo e, até por isto, eram feitas quase sem pressão por parte dos estúdios. Este contexto converteu Hughes de roteirista do grupo National Lampoon ${ }^{61}$ em um dos mais prestigiados diretores da década de 80 nos EUA.

Com uma fórmula simplificada de fazer fílmico, Hughes emplacou hits cinematográficos que ainda hoje têm grande apelo

60 A maioria dos argumentos levantados nesse trabalho foram desenvolvidos coletivamente em debates do Grupo de Pesquisa Olhares sobre a escola: a educação nos discursos de entretenimento, vinculado ao Setor de Educação da UFPR e financiado pela PRAE/UFPR. Agradecemos a Andressa Fontana Pires, Débora Tamires Porcel, Marilene Noriko Treider Otani, Roberto Jardim e Vanessa Raianna Gelbecke por seu engajamento no grupo durante o segundo semestre de 2011 e pelas ideias compartilhadas.

61 Um dos mais cultuados grupos de comédia dos anos 70 nos Estados Unidos, a National Lampoon, começou como uma revista mensal produzida por estudantes de Harvard. Após um grande sucesso, o grupo passou a incorporar atores, roteiristas e diretores em seus quadros. Alguns dos principais filmes da marca são Férias frustradas (1983) e Clube dos cafajestes (1978). 
e influência. Não por acaso, é referenciado em Hollywood como pai do gênero high school. Ele (re)elaborou uma narrativa cinematográfica pautada nas relações de sociabilidades juvenis, retratando o contexto dos anos 80. Sua obra pode ser caracterizada como um dos maiores sucessos numa década que viu explodir o mercado juvenil. Segundo Susannah Gora:

[...] creating smart entertainment for young people wasn't just the sensitive thing to do; it also made great business sense, because teenagers had indeed became an increasingly powerful demographic around this time. Spurred on by the rise of two-income families and the fact that many kids held after-school jobs, teens spending [in US] skyrocketed between 1975 and 1985, even though the teen population shrank in those years $^{62}$ (GORA, 2010, p.66-67).

Ainda que não fosse nova, a representação da juventude no cinema sofreu alterações relevantes na década de 80 , dando ensejo a um significativo corpus cinematográfico com características próprias, como a preferência pela encenação do contemporâneo, a contestação da sociabilidade escolar e do mundo adulto e a difusão de padrões estéticos e de consumo. Paulatinamente, os filmes high school passaram a ser reconhecidos como um gênero próprio, com

62 “ $[\ldots]$ criar programas de entretenimento astutos para jovens não era apenas uma questão de sensibilidade; também fazia muito sentido empresarial, pois os jovens tinham de fato se tornado um grupo demográfico relevante durante esse período. Estimulados pelo aumento das famílias com dois rendimentos e pelo fato de muitos/ as jovens terem empregos de meio período após a escola, o poder de gasto dos jovens [nos EUA] elevou-se assustadoramente entre 1975 e 1985, mesmo que o número total de jovens tenha diminuído ao longo dos mesmos anos" (GORA, 2010, p. 66-67, tradução livre). 
características facilmente identificáveis e estratégias de enunciação recorrentes.

Em Hollywood goes to school, Robert Bulman (2005) propõe classe social como um critério de análise para as produções sobre high school, identificando duas categorias de filmes. A primeira delas retrata comunidades urbanas pobres com alta incidência de afro-americanos/as e/ou latinos, nas quais o enredo está focado em uma figura institucional (quase sempre um/a professor/a) de classe média que supera a hostilidade inicial de estudantes pobres, revoltados e "sem futuro" em favor da plena integração escolar. Em tais filmes os/as estudantes são transformados em função da atuação catalisadora e apaixonada de um/a adulto/a que lhes oferece oportunidades de desenvolvimento através do saber escolar, do ingresso na faculdade, etc. Em larga medida favoráveis à manutenção do status quo, tais narrativas representam negativamente as estratégias de subversão e contestação juvenis. Enfatizam um tipo específico de futuro ideal ou ação salvadora: a da classe média - capaz de sanar conflitos através do crescimento individual, prescindindo de transformações sociais de maior envergadura. São representativas dessa espécie de filmes obras como Lutando contra o destino (EUA, 2005) e $O$ triunfo (EUA, 2006).

Saindo dos bairros pobres concentrados nas grandes metrópoles, uma segunda categoria catalogada por Bulman dá preferência à representação de adolescentes pertencentes à classe média moradores dos subúrbios. Em tais produções o/a protagonista geralmente não é um/a adulto/a, mas um/a jovem em busca de seu "verdadeiro eu”. Tal busca implica questionar os padrões estabelecidos, seja pela família, pela instituição escolar ou pelo grupo de amigos/ as - padrões que impõem limitações e exigem uma superação corajosa para "ser você mesmo". Longe de valorizar a educação formal, o cinema de high school que retrata a classe média privilegia saberes 
não escolares, especialmente aqueles ligados a relacionamentos humanos, autodescoberta e expressão pessoal.

Na tipologia elaborada por Bulman ${ }^{63}$, os filmes de Hughes são facilmente identificados com a segunda categoria, relacionada aos colégios de subúrbio frequentados por adolescentes de classe média. A questão de classe não está completamente ausente dos enredos de Hughes, mas as escolas representadas estão bem distantes do estereótipo pichação/violência/reprovação característico dos filmes sobre jovens pobres. Os cenários privilegiados por Hughes são tipicamente classe média. Mesmo personagens retratados como pobres não vivem dinâmicas de superação como as preconizadas nos filmes da primeira categoria. Em contraste com a negligência e ausência características dos estereótipos das famílias de baixa renda, na vida dos heróis e heroínas de Hughes, há certa estabilidade domiciliar e o cotidiano não é violento - exceção feita ao personagem Bender, de Clube dos cinco. De forma simplificada, podemos dizer que em Hughes o "lado errado do trilho", não é tão cruel nem tão violento quanto nos filmes que retratam escolas em áreas urbanas pobres.

Em relação ao saber escolar, as obras de Hughes corroboram plenamente a tipologia formulada por Bulman. Cenário secundário para dramas infinitamente mais importantes, as salas de aula não são o espaço preferencial para a ação da câmera. Tal como retratado pelo cinema hollywoodiano, a trama escolar está relativamente distante dos conteúdos disciplinares e as funções educacionais da instituição são secundárias. $\mathrm{O}$ contraste mais significativo traçado por Hughes entre o currículo obrigatório e os interesses juvenis

63 A análise de Bulman inclui ainda filmes que retratam escolas particulares na qual convivem jovens ricos e "filmes estrangeiros" (categoria esta duvidosamente colonialista), ambos com menor expressividade (quantitativa) na produção cinematográfica analisada pelo autor e que não serão debatidos aqui. 
se revela em Curtindo a vida adoidado. Ferris demonstra profundo desinteresse pelo programa de história econômica (o tal socialismo europeu) e Hughes utiliza diversos artifícios de linguagem fílmica para acentuar o contraste entre a escola e a "vida". Enquanto Ferris conversa com o público, canta no chuveiro, ouve música, dança, prova um coquetel e toma banho de sol, cortes alternados mostram na escola o professor fazendo vagarosamente a chamada. Não apenas as cores e a iluminação, mas a trilha sonora, a movimentação de câmera e a montagem reforçam a representação da sala de aula como espaço de monotonia e tédio, enfatizado pela expressão facial dos/as estudantes. Enquanto a "vida" fora da escola segue uma estética vídeo-clipe, os estudantes dormem e babam sob a luz fria e a voz repetitiva do professor em enquadramento estático.

O papel desempenhado pelos educadores em amplo sentido (os adultos, sejam professores/as, pais, mães ou diretores) é retratado por Hughes costumeiramente de modo jocoso. Diferentemente dos filmes que delineiam um adulto-salvador para a juventude pobre, em Hughes, o adulto é ou repressor da liberdade adolescente e/ou alienado da sociabilidade juvenil, incapaz de diálogo e compreensão. $\mathrm{O}$ distanciamento do mundo adulto é, com efeito, um dos maiores articuladores da vivência comum adolescente, algo capaz de amenizar as diferenças entre um esportista, um nerd, um loser, uma princesa e uma louca - tal como descrito em $O$ clube dos cinco. Allison, a louca, resume o consenso do grupo e sua separação do universo adulto com uma frase: "Quando você cresce, seu coração morre”.

\section{Jornada do herói adolescente: como deixar de ser ninguém}

Seria, entretanto, desrespeitoso e limitador imaginar que a rejeição ao currículo escolar e ao mundo adulto implica a recusa ao processo educacional como um todo. Ponto comum aos filmes de 
Hughes, fiel ao esquema da jornada do herói, é o percurso de aprendizado preconizado pelos protagonistas e/ou coadjuvantes. $\mathrm{Na}$ maioria das vezes, os personagens estão em uma posição desprivilegiada no universo escolar, quando determinada situação e/ou sua própria coragem os fazem entrar em uma peregrinação por "terras estranhas" (mesmo dentro da sociabilidade escolar), onde passarão por momentos de dificuldade, de reflexão e mudarão sua forma de pensar. Por fim, os heróis e heroínas evidenciarão quão mesquinha é a vida dos/as populares, quão desrespeitados são os sentimentos dos desprivilegiados/as na escola e/ou quão viciadas são as concepções de mundo que permeiam as relações adultas - compartilhando com o seu círculo de convivência (e com o público que assiste ao filme) os aprendizados alcançados ao longo do percurso. Essa forma narrativa tem óbvias conexões com a lógica estrutural da jornada do herói, difundida em Hollywood por Christopher Vogler com base na obra de Joseph Campbell ${ }^{14}$.

As relações com colegas e a superação das dificuldades enfrentadas (ainda que distantes das avaliações escolares) são as verdadeiras lições preconizadas pelas produções de Hughes. Se as relações com a escola são amplamente desinteressantes, as relações na escola (entre estudantes e de estudantes com os poderes institucionais) são o alvo principal de reflexão, tanto para revelar como para criticar o sistema social reinante nas high schools estadunidenses.

64 De acordo com tal estrutura narrativa, o/a protagonista atravessa as seguintes etapas: mundo comum; chamado à aventura; recusa do chamado; encontro com o mentor; travessia do primeiro limiar; realização de testes e provações, encontro com aliados e com inimigos; aproximação da caverna oculta; provação suprema; recompensa; caminho de volta; ressurreição; retorno com elixir (VOGLER, 2006, p. 27). Trata-se de um percurso de aprendizado clássico, identificável de alguma forma em todos os filmes aqui debatidos. 
Sherry B. Ortner argumenta que há, nas high school estadunidenses, um sistema social específico cujo habitus apresenta extraordinária duração histórica e abrangência geográfica. A vida social entre estudantes da high school envolve ser ininterruptamente julgada e avaliada, num processo de rotulação que atribui a cada pessoa um "tipo" hierárquico. A despeito das mudanças de nomenclatura ao longo do tempo, Ortner defende que os tipos permanecem relativamente constantes:

(i) populares: representantes de turma, esportistas, cheerleaders, promqueens (topo da pirâmide escolar);

(ii) losers: nerds, geeks, eggheads (bizarros e estranhos, mesmo que muito inteligentes);

(iii) outsiders: hoods, druggies, burnouts, greasers, hempies, sluts (drogados, revoltados e subversivos em geral, com forte estigma desfavorável à população de baixa renda) e, finalmente;

(iv) nobodies: "ninguéns" (pessoas que não se encaixam em nenhuma das outras denominações e são ignoradas pelos que estão acima na escala hierárquica).

Os tipos sociais estruturam o universo simbólico escolar no qual todos devem operar. Para a maioria dos/as estudantes, independente da categoria, ser popular é a meta principal, o que explica o esforço de manutenção do status quo por parte daqueles que estão no topo da hierarquia de prestígio.

Para Ortner, há uma lógica subjacente ao sistema social escolar que se baseia em dois eixos: classe social e personalidade/caráter. Apesar das diferenças de classe geralmente não serem expressas em léxico político ou com referências ao mundo do trabalho, a desigualdade opera de maneira evidente na linguagem da distinção (em sentido bourdieusiano). Para alguém engajado no vocabulário cotidiano, roupas, acessórios, vizinhança, ascendência e disponibilidade 
de dinheiro são códigos precisos de alocação na tipologia que separa "os que têm" dos que "não têm".

A origem de classe, todavia, não tem exclusividade na determinação da categoria de pertencimento de alguém. Ser inteligente, atraente, talentoso e envolvente são igualmente importantes e se relacionam com uma dimensão de personalidade ou caráter individual, sendo possível que alguém cuja família é pobre circule entre os/as populares ${ }^{65}$. A origem de classe se articula com o eixo personalidade/caráter, já que está diretamente relacionada ao desenvolvimento da autoestima, da extroversão e do carisma características cruciais para a popularidade. Ortner salienta que as categorias são definidas e atribuídas a partir da perspectiva de quem está no topo. Aparência e charme não são atributos intrínsecos, mas construídos e valorizados em contexto: utilizados ativamente para assegurar a estrutura de poder vigente.

Apesar da questão do prestígio ser problematizada em todas as obras de Hughes aqui debatidas, Clube dos cinco se destaca tanto pela extrema estereotipização dos personagens quanto pela densidade da trama explicitamente crítica aos limites impostos pelos grupos de convivência. $O$ cenário quase exclusivo do filme é a biblioteca da Shermer High School, onde cinco estudantes cumprem nove horas de detenção em um sábado. $\mathrm{O}$ fato de passarem o dia juntos de pessoas com as quais não conviveriam no cotidiano "normal" é o gerador de conflito.

Ao longo da trama, os cinco estereótipos (o esportista, a princesa, o outsider, o nerd e a louca) se veem obrigados, não sem dificuldades, a retirarem as máscaras e revelarem suas similaridades.

65 Nos filmes de Hughes, essa é precisamente a posição de Amanda Jones em Alguém muito especial. Sua beleza e o relacionamento com um dos garotos ricos (Hardy) são os principais capitais de que dispõe no mercado escolar. 
Como expressa Brian Johnson, o nerd, após um dia de convívio forçado: "os termos mais simples e as definições mais convenientes" não são suficientes para descrever o que cada uma das pessoas envolvida é. A conclusão do filme atesta claramente que todos são a junção dos diferentes estereótipos. Para que o final redentor se enuncie, todavia, é necessário que cada estereótipo seja elaborado, confrontado e desconstruído. Claire, a princesa, por exemplo, deve responder por seus privilégios de classe (cujo emblema são os brincos de brilhante, a BMW de seu pai e o sushi para o almoço), por sua conduta "popular" e decorrente menosprezo que reserva aos "ninguéns". Depois que a amizade entre o grupo é selada com o "fumo da paz" - numa representação hiperbólica do uso de maconha - Claire afronta o outro membro popular presente, o esportista Andrew:

(1h20’48) “Se o Brian chegar para falar com você na segunda-feira, o que você vai fazer? Imagine isso. Você com todos os seus amigos esportistas. Você sabe exatamente o que vai fazer. Vai falar 'oi', e quando ele sair... vai zoá-lo e todos os seus amigos vão achar que você realmente não gosta dele”. (Clube dos Cinco, Hughes, EUA, 1985).

A lucidez e a sinceridade de Claire testemunham a pressão do grupo de influência, que constrange as relações de amizade em conformidade com a necessidade de manutenção do sistema hierárquico vigente, tal como elaborado por Ortner. Um dos problemas com Brian, enunciado já nos primeiros diálogos do filme, é não acessar as sutis diferenciações entre os clubes de matemática, física ou latim, dos quais faz parte, e o conselho estudantil, no qual Claire está engajada. Brian é, neste sentido, o estereótipo do nerd, alguém incapaz de compreender e articular os códigos de conduta vigentes 
e perceber a diferença entre os clubes acadêmicos (dos nerds) e os sociais (dos populares).

A declaração franca feita por Claire, todavia, é simultaneamente possibilidade de redenção para Brian, pois permite enfatizar sua superioridade moral em relação à falsidade dos populares, já que ele cumprimentaria qualquer um/a na segunda-feira, incluindo Claire. Assim como acontece com estes dois personagens, que passam por uma jornada de superação pessoal, todos os outros adolescentes retratados no filme atravessam jornada similar. Segundo Vogler (2006), a complexidade do roteiro é diretamente proporcional à dificuldade em enquadrar (analiticamente) os personagens apresentados na chamada jornada do herói. Ao invés de apenas um, são cinco os heróis retratados no filme e todos são também simultaneamente mentores e vilões uns para os outros.

Anthony Michael Hall ${ }^{66}$, ator que interpreta Brian, é a imagem do geek nos filmes de Hughes. Além de Clube dos cinco, Hall está presente em Gatinhas e gatões (como Farmer Ted) e Mulher nota mil (como Gary) - personagens que inspiram simpatia e pena. Ligeiramente ruivo e desengonçado, com a boca constantemente aberta numa cabeça desproporcional ao corpo franzino, Hall incorporou durante os anos 80 uma figura recorrente na sociabilidade escolar estadunidense: aquele que tenta, mas é incapaz de ser (positivamente) popular. $\mathrm{O}$ geek é com frequência cronicamente apaixonado por uma garota popular, alguém além de seu estatuto que o rejeita reiteradas vezes.

Cada uma das jornadas percorridas por Hall nos roteiros de Hughes estabelece críticas ao estatuto da popularidade, ironizando

66 Alguns críticos argumentam que Hall encarna o alter ego de Hughes, predicado reforçado pelo diretor ter interpretado o pai de Brian em Clube dos cinco, ainda que numa aparição de poucos segundos e sem diálogo. 
as expectativas de comportamento ao exagerar o estereótipo e insinuar outras possibilidades de vivência, outras estratégias de reconhecimento social. Os personagens de Hall são também reencarnações da figura do bobo, que tem a prerrogativa de contestar através do humor a seriedade do melodrama (MARTÍN-BARBERO, 2001) - sem abandonar seu papel de "bobo", alvo para o riso alheio. Não é sem importância que ao final de Clube dos cinco, Claire encarregue Brian de fazer a redação a ser entregue ao diretor, trabalho que deveria ter sido feito por todos - e ele cumpre a missão.

O filme no qual os nerds não fazem apenas papel coadjuvante, mas estão no centro da trama é Mulher nota mil, misto de ficção científica e humor exorbitante. Gary e Wyatt são dois pobres coitados na escola. Na cena de abertura, suas fantasias megalomaníacas de popularidade são interrompidas por dois esportistas que abaixam seus shorts e cuecas para todo o ginásio. $\mathrm{O}$ desespero dos amigos por se fazerem respeitáveis só é concretizado quando reencenam Frankstein (aliás, transmitido pela TV ao fundo do quadro) ao criarem no computador uma "mulher nota mil", Lisa, que se materializa em carne e osso como uma Barbie gigante com cérebro de Einstein. São os poderes mágicos de Lisa que garantem a Gary e Wyatt alcançar notoriedade e ela atua como mentora ao ensinar aos jovens as estratégias de distinção escolar.

"Possuir” uma mulher é sem dúvida o principal marcador de prestígio - ainda mais uma que seja ao mesmo tempo propriedade e criatura. Mas a construção da popularidade masculina passa também por desfilar carros de luxo, promover festas arrasadoras em casa e demonstrar coragem publicamente ao enfrentar um grupo de motoqueiros assassinos para proteger moças indefesas (muito apropriadamente, as moças protegidas tornam-se depois as namoradas de Gary e Wyatt). 
Mulher nota mil é significativamente diferente dos demais filmes produzidos por Hughes sobre o contexto escolar por trabalhar com a fantasia típica da ficção científica. Não é sem importância que nerds tenham espaço para alcançar a popularidade apenas em um mundo imaginário no qual mulheres podem ser criadas no computador e pianos voam pelas chaminés. Os nerds apaixonados da vida "real" dos outros filmes não conquistam o objeto de seu desejo. Tanto Farmer Ted, em Gatinhas e gatões; quanto Duckie, em Garota de rosa shocking, assistem a protagonista pela qual são apaixonados consolidar um romance com um rapaz popular. $\mathrm{O}$ bobo pode questionar e fazer graça, mas sua coroa existe apenas no carnaval.

Assim como Hall foi um par constante de Hughes nos filmes de high school da década de 80, Molly Ringwald alcançou enorme popularidade nos EUA a partir de suas parcerias com o diretor. Ringwald foi Claire em Clube dos cinco, Samantha em Gatinhas e gatões e Andie em Garota de rosa shocking, protagonista em cada um dos respectivos filmes. A presença marcante tanto de Hall quanto de Ringwald nos filmes de Hughes pode ser facilmente explicada seja pela preferência do diretor, publicamente declarada, seja pela influência determinante do estrelato autorreprodutor - certamente ambos os aspectos estão presentes na repetição do casting. Menosprezar, todavia, o potencial de identificação alçado por tais escolhas recorrentes seria diminuir a importância do processo de enunciação vigente (cf. MORIN, 1989). Ao contrário de Hall, destinado ao papel de geek, Ringwald representou quase toda a gradação hierárquica escolar. Foi "princesa" com Claire, "ninguém" com Samantha e "outsider-pobre" com Andie. Menos baseadas no humor, as personagens de Ringwald expressam experiências e denúncias de outros matizes, apesar de suas jornadas ecoarem de forma repetitiva as expectativas de feminilidade vigentes (especialmente relacionadas à beleza e amor). 
Gatinhas e gatões, por exemplo, desenrola-se no dia em que Samantha (a versão "ninguém" de Ringwald) completa dezesseis anos. Seus pais, preocupados com o casamento da filha mais velha no dia seguinte, esquecem-se do aniversário e emprestam seu quarto para os antipáticos avós-hóspedes, aumentando a miséria de uma adolescente obsessivamente preocupada com seu corpo. $\mathrm{Na}$ escola, Sam responde a um conjunto de questões sigilosas feitas pelas amigas: Você jáfez... [sexo]? Não. Com quem faria? Jake Ryan. O papel com as respostas deveria ir para a mesa da colega de trás, mas cai acidentalmente e é coletado por ninguém menos que Jake Ryan, amor platônico de Samantha - com quem um namoro seria pouco provável em virtude da hierarquia de prestígio. De acordo com a melhor amiga de Sam: "Ele nem sabe que você existe!"

Jake Ryan namora Caroline, a cheerleader loira, linda e rica. As dinâmicas de feminilidade expressas em Gatinhas e gatões revelam processos de competição baseados no corpo e indicam a importância de abnegação feminina (implícita na menção no irmão surdo de Caroline), dando sinais das diferenças de gênero nos parâmetros de popularidade. Ao ler o papel com seu nome, Jake Ryan "vê" Samantha, investiga sobre ela junto ao geek Farmer Ted (interpretado por Hall) e, insatisfeito com a namorada Caroline, aparece como um príncipe encantado para a aniversariante, com um bolo de dezesseis velas. Jake resgata Samantha no final da festa de casamento, onde ela tinha sido esquecida outra vez pela família. $\mathrm{O}$ novo príncipe não monta mais num cavalo branco, mas num conversível vermelho de preço elevado. Através do amor, a barreira de popularidade é rompida - todos podem ser felizes a despeito dos estereótipos reinantes (basta ser bonita o suficiente).

É também o amor o grande catalisador para o processo de superação em Garota de rosa shocking. Ringwald interpreta Andie, uma adolescente cujo pai desempregado, alcoólatra e abandonado 
pela esposa não garante à filha as marcas de distinção essenciais ao convívio escolar. A escola de Andie é segmentada por classe, barreiras geográficas nítidas marcam a separação entre "os-que-têm" e os outros, para usar a terminologia de Ortner. O pátio interno é o reino dos ricos. O pátio externo é o local de convivência dos menos privilegiados. Atravessar essas barreiras equivale a sair do "mundo comum". As colegas ricas estigmatizam Andie por suas roupas e acessórios, que ela seleciona com muito apreço estético por preços módicos pagos por seu emprego part-time em uma loja de discos. Os amigos e amigas de Andie também menosprezam os ricos, dando representatividade à classe como critério de segmentação social.

A despeito de seu status, Andie chama a atenção de Blane, rico, popular e veterano, com quem inicia uma controversa relação desaprovada pelos amigos/as de ambos. Assim como em Gatinhas e gatões, são as últimas cenas, no baile do colégio (quando Andie estreia seu vestido rosa shocking customizado), que selam o "viveram felizes para sempre". Uma versão bastante tradicional de romance está presente nos dois filmes, nos quais a concorrência com outros rivais alimenta a iniciativa tipicamente masculina e os conflitos pessoais das personagens femininas são sanados automaticamente com as juras de amor.

\section{O lado errado dos trilhos: dinheiro e glamour na popularidade escolar}

O exemplo dado por Garota de rosa shocking já seria suficiente para questionar a tipologia de Bulman, segundo a qual, as relações de classe não são enfatizadas nos filmes que retratam escolas de subúrbio. Mas Alguém muito especial, ao reencenar o drama de Andie pelo viés masculino, acentua os conflitos econômicos presentes na sociabilidade escolar. Keith é um rapaz que "vive do lado errado 
dos trilhos", local que a câmera explora já nos momentos iniciais do filme. Para grande contrariedade de sua melhor amiga (Watts), ele se apaixona por Amanda que, apesar de morar na mesma vizinhança, transita entre a elite do colégio em razão de sua beleza, carisma e relacionamento com Hardy, rico, popular e mau caráter. Em Alguém muito especial, há relativa sintonia entre a posição social (capital econômico) de cada personagem e sua respectiva categoria de pertencimento e/ou status do ambiente escolar.

Segundo Vogler (2006), a narrativa clássica do herói exige apresentá-lo em seu mundo comum para em seguida mostrar, com nitidez, o contraste de seu ambiente costumeiro com o mundo especial no qual irá empreender a aventura. Na volta do trabalho, Keith encara fixamente Hardy e Amanda na frente da casa dela. Hardy vai embora em seu carro luxuoso. Keith abaixa a cabeça e olha para as mãos sujas de graxa. $\mathrm{O}$ conjunto de signos que diferenciam Hardy e Keith são enunciados de modo enfático: a distinção social expressa no carro (bem de consumo por excelência da masculinidade hegemônica) em contraste com o trabalho manual de Keith, que conserta carros alheios.

Em cena posterior, Hardy e Amanda vão ao posto de gasolina/ oficina onde Keith trabalha. É visível a expressão de superioridade de Hardy desmerecendo o emprego de Keith, colocando-o em uma posição de submissão calcada no poder econômico. Observa-se que as posições de prestígio perpetuam seu significado para além dos muros da escola, fazendo com que Hardy seja "superior" mesmo num espaço social distinto do colégio. Numa clara tática de sabotagem, Keith se vinga ao retirar o medidor de óleo do carro e jogá-lo no lixo, promovendo a contestação da ordem social estabelecida dentro de seus limites de ação.

Em casa, seu pai (Cliff) lhe cobra interesse por entrar numa faculdade, entendendo-a como uma possibilidade para melhores 
condições de vida - revelando o principal conflito geracional do filme: o drama clássico vocação artística juvenil x pragmatismo econômico adulto. Em mais de uma cena, o amor de Keith pelo desenho e pela pintura se expressa nas representações que ele faz de Amanda. Cliff, por sua vez, imagina para o filho uma carreira em administração - e não artes - na expectativa que Keith tenha um bom emprego, isto é, angarie retorno a médio prazo com investimento em formação acadêmica. Por isso, incentiva a manter sua poupança, acreditando que por intermédio da escolarização, Keith poderá ser o primeiro membro da família "que não irá precisar lavar as mãos depois de um dia de trabalho".

Watts, a melhor amiga de Keith, desaprova seu amor por Amanda (afirmando que se trata de mero desejo sexual) e expressa sua aversão pelos ricos, os populares da escola, que "pisam" nas outras pessoas. Amanda, mesmo não sendo rica, é digna de desprezo por andar com os populares e fazer parte desse grupo por associação. Os populares retratados em Alguém muito especial são, em sua maioria, oriundos da classe média alta - como Hardy e Shayne (melhor "amiga" de Amanda). As possibilidades de destino para as férias, a diferença na qualidade de automóveis, roupas, assessórios e etc. são recorrentes marcações de superioridade econômica empregadas ao longo da narrativa. Como em $\mathrm{O}$ clube dos cinco, brincos de brilhante são utilizados como acessórios enunciando distinção, acessórios a que Amanda tem acesso por meio de empréstimos de Shayne.

A posição de Amanda entre os populares se sustenta a partir de sua beleza, salientada pela câmera em uma cena no vestiário, na qual Watts compara dolorosamente seu corpo magro, infantil e masculinizado à seminudez panorâmica e sensualizada de Amanda. Em perfeito acordo com o esquema voyeurístico de objetificação do corpo feminino descrito por Laura Mulvey (2004), Watts observa atentamente o corpo de Amanda e compara ao seu próprio, numa 
enunciação muito semelhante à da cena em que Samantha julga a si mesma em frente ao espelho em Gatinhas e gatões. O olhar hipnotizado de Watts só é interrompido quando outra garota presente no vestiário pergunta, com ar de deboche, se ela por acaso estaria usando uma cueca - enfatizando ainda mais a feminilidade "mal sucedida” de Watts. Parte da "inveja” suscitada pelo capital corporal de Amanda se deve à possibilidade que tem de alcançar o que deseja por meio da beleza. É com um jogo de sedução que Amanda persuade o orientador a liberá-la da detenção, é mediante o seu relacionamento com Hardy que se insere no grupo dos populares, é ainda a beleza de Amanda que faz com que Keith se apaixone por ela - mesmo não a conhecendo - enquanto Watts, que está sempre junto com Keith, ama-o secretamente e não é notada. Amanda é personificação da musa - reforçada pelo fato de ser a principal inspiração de Keith em seus desenhos.

Apesar de sua beleza invejável, o prestígio de Amanda depende diretamente do namoro com Hardy, o que se evidencia pelo fato de sua posição ser ameaçada quando termina a relação. Nota-se que o princípio de diferenciação dos populares em sua posição de "superioridade" está pautado tanto no capital econômico, como no habitus relacionado ao espaço social a que estes agentes pertencem, em conformidade com a teoria de Bourdieu (1992). A conjugação dos signos de distinção e das predisposições estabelece o lugar ocupado pelos agentes na escala hierárquica. $\mathrm{O}$ que está em jogo é o estabelecimento de uma diferenciação a partir da noção de espaço que, segundo Bordieu (1992), é produto de um conjunto de posições distintas definidas em uma relação de exterioridade mútua; ou seja, por relações de proximidade e/ou distanciamento configurando um ordenamento. Essa diferenciação social estabelecida a partir da não interação entre os populares e os/as “ninguém” está relacionada à perpetuação da hierarquia de prestígio. Cada estudante é rotulado 
e isto designa o espaço de convívio. Numa configuração de relações sociais em que os agentes são dotados de categorias de percepção e classificação compartilhadas, a "diferença só se torna signo de distinção (ou vulgarização) se lhe aplicarmos um princípio de visão e de divisão” (BOURDIEU, 1992, p. 23).

A preocupação dos populares de que um "dos seus" se relacione com um integrante de um grupo tido como inferior está diretamente relacionada à necessidade de manutenção de seu prestígio. Esta lógica converge com a ideia de Berger sobre o glamour: "ser invejado é uma forma solitária de confiança. Depende de não compartilhar sua experiência com aqueles que o invejam. Você é observado com interesse, mas não observa - se o fizer, tornar-se-á menos invejável” (BERGER, 2001, p. 135). A recusa de amizade, e mesmo atenção por parte dos populares em relação ao outro cuja posição é desfavorável na escala de status, equivale a uma estratégia de diferenciação social. A superioridade dos/das populares é sustentada e legitimada pela "inveja" dos demais, visto que detêm bens e privilégios desejados (carros, joias, roupas, viagens, etc.) e uma posição almejada por "todos" no quadro de relações sociais desiguais.

Conforme Berger, uma pessoa glamourosa é digna de inveja: está além do conflito e responde com desinteresse os olhares que lhe são dirigidos. Isso pode ser visualizado com maior clareza no filme Clube dos cinco, especialmente no diálogo já citado sobre não cumprimentar os novos amigos no colégio segunda-feira ( $\mathrm{O}$ mundo comum). Claire, a tipificação da popular, afirma que o nerd Brian não teria vergonha de cumprimentá-la segunda, pois os amigos de Brian a admiram. Se ela, em contrapartida, conversasse com um nerd, isso significaria um rebaixamento no status de popularidade, ou seja, a quebra do glamour. 
Em Alguém muito especial, a exclusão de Amanda do círculo dos populares está relacionada tanto com o rompimento do namoro com Hardy como com a anuência ao convite de Keith (um nobody) para um encontro. Pela lógica campbelliana, ela é chamada à aventura e, ao aceitar, atravessa o limiar. Trata-se de um fato inesperado: uma quebra da hierarquia de status. É significativo, porém, que Amanda tenha aceitado o convite logo após ter presenciado uma traição de seu namorado ${ }^{67}$. Na construção narrativa do filme, assim como nas demais obras de Hughes, o que está em jogo é a contestação da escala hierárquica escolar.

Tanto é que alguns colegas homens parabenizam Keith por sua "conquista". Duncan, o assustador colega de detenção, comenta que toda a vez que um "pobretão" rouba a namorada de um cara como Hardy é motivo para comemorar. Por outro lado, o grupo em que Amanda está inserida espera que ela fique novamente com Hardy. Shayne ironiza a possibilidade de Amanda estar realmente interessada em Keith e formula planos para que Amanda possa "dar um fora" nele e, dessa forma, colocá-lo em seu devido "lugar”. Frente a sua negativa, responde com o menosprezo típico que caracteriza o glamour. As relações estabelecidas entre os/as estudantes evidenciam sua lógica interna, pautando a mesquinhez e os vícios dos populares que estão preocupados na manutenção de sua posição de prestígio no ambiente escolar. Em conformidade com a estrutura

67 Hardy aparece em diversos momentos seduzindo outras garotas. Mesmo namorando uma das mais "cobiçadas" da escola, o mau-caráter Hardy sente a necessidade "ter" outras mulheres. O fato de ele ser "popular, bonito e rico" contribui para que "conquiste" as meninas. Na medida em que "possui” várias meninas bonitas, reforça sua popularidade ao mostrar o quão "poderoso/másculo" é. A sedução masculina é valorizada enquanto um signo de distinção que produz "inveja" aos demais meninos do ambiente escolar, mas nesse caso negativo em contraposição ao personagem íntegro e verdadeiramente apaixonado encarnado por Keith. 
do melodrama e sua recorrente deslegitimação das figuras de poder e importância (MARTÍN-BARBERO, 2001), os/as populares nos filmes de Hughes são frequentemente personagens falsos, mentirosos, pouco confiáveis e interesseiros ${ }^{68}$.

É significativo que a narrativa do filme ao mesmo tempo conteste e reforce o poder do dinheiro. Para organizar um encontro perfeito com Amanda, Keith não apenas mobiliza toda sua comunidade de amigos como utiliza a poupança destinada à faculdade, para enorme desespero de seu pai. Quando Cliff descobre o saque, resolve confrontar o filho - dando vazão aos conflitos geracionais. A conversa se transforma em um não-dialogo: Keith expressa o sentimento de não ser escutado, já que o pai impõe arbitrariamente o ingresso na faculdade visando à ascensão social. É ainda, no momento de conflito, que o protagonista pode expressar sua frustração por ser encarado como um ninguém - ao relatar que seu desprestígio advém do fato dele gostar de artes, trabalhar numa oficina e ser amigo de uma pretensa lésbica. Evidenciam-se, nesse momento, os signos de distinção que estão sendo julgados e que o rotulam negativamente. Keith está disposto a gastar suas economias, com o intuito de mostrar a Amanda (e a todos/as na escola) que ele é capaz - que é tão bom como qualquer outro. Que mesmo um "ninguém" merece atenção.

Todo o encontro com Amanda é meticulosamente planejado para mostrar o quanto ele poderia ser interessante - arranja um carro elegante, leva Amada a um restaurante luxuoso para comer o caviar mais caro do cardápio e a presenteia com um par de brincos de brilhante. É em larga medida no poder do dinheiro que reside

68 Hardy é um dos principais exemplos, mas não o único. Em A garota de rosa shocking, Steff representa o antagonista em um personagem cuja moral decadente reforça a imagem negativa dos garotos ricos e inconsequentes. 
a possibilidade de mostrar publicamente que não é um "ninguém". Por outro lado, os melhores momentos do encontro ocorrem quando Keith mobiliza recursos que não necessitam do capital econômico ou do status representado pelo dinheiro. O pai de seu colega Duncan é segurança de um museu e possibilita a entrada do casal durante a noite para ver a exposição - na qual foi incluído um desenho da própria Amanda feito por Keith.

Evidencia-se o quanto o julgamento dos demais interfere na construção da autoimagem, aos poucos, o herói desnuda as amálgamas de suas relações sociais e sua insatisfação com o lugar de desprestígio que lhe foi destinado. Aos olhos dos outros, ele não é nada, ou melhor, (utilizando a designação de Ortner), ele é um ninguém. Numa das cenas iniciais, Keith permanece em cima do trilho do trem numa postura semissuicida, aguardando-o até o último momento para se movimentar. Isso pode ser lido como a expressão de sua sensação de inexistência, tamanha inexistência que seria possível deixar de existir sem que sua ausência fosse notada ${ }^{69}$. A narrativa do filme é um esforço para provar o contrário, Keith enfrenta os limites/poderes estabelecidos, tanto a imposição do mundo adulto representada por seu pai e a obrigação de seguir uma carreira sem interesse quanto o ódio aos populares representado pela dinâmica de sociabilidade escolar.

Da mesma maneira que Gary e Wyatt, em Mulher nota mil, passam a ser notados quando são vistos junto a uma mulher sexualmente desejada, Keith alcança notoriedade a partir do

69 De forma semelhante, em Clube dos cinco, Andrew (o esportista) fala para Bender (o outsider) que sua existência não é significativa, que se Bender "desaparecesse para sempre, nem faria diferença”. Em Curtindo a vida adoidado, Cameron encara uma obra de arte no museu de forma tão insistente que o trabalho de câmera aproxima a imagem a ponto dela desfocar e a criança retratada na pintura se tornar apenas um borrado de tinta, perdendo assim seu status de pessoa, passa a ser ninguém. 
relacionamento com Amanda. O capital corporal da beleza nessas representações cinematográficas se traduz em prestígio tanto para a mulher, objetificada enquanto corpo, como para o homem que a "conquista". Ao longo da trama de Alguém muito especial, a própria Amanda demonstra possuir a percepção da unidimensionalidade com que as pessoas a observam: exclusivamente por sua beleza. Ela reconhece que mobilizou sua beleza para angariar dividendos ao aceitar o papel superficial de "linda" e não ficar sozinha, mesmo que nisso estivessem envolvidos os "motivos errados". Ao conversar com Keith, declara ter vergonha de sua origem social e ódio de ver seus "amigos" (populares) terem tudo que desejam. Keith também é acusado de usar Amanda como objeto de prestígio. O confronto dos dois produz reflexões que modificam a forma deles pensarem. Ao final da cena, eles se beijam, denotando mais uma vez o poder transformador do amor.

Depois dessa reflexão, ambos dirigem-se para casa de Hardy, a despeito da discordância de Amanda. Esse é o momento da provação suprema em que, segundo Vogler (2006), o herói enfrenta o seu maior medo ao combater as forças inimigas. Keith confronta a figura dos populares/ricos, personificada por Hardy, e põe em destaque toda a mesquinhez e arrogância dos populares. Contando com a ajuda dos aliados que conquistou ao longo da trama Duncan e outros garotos da detenção - vence a batalha e humilha Hardy na frente de grande parte da escola (ou seja, em público). Assim, a concepção de que os populares/ricos podem tudo é desmistificada. Ao sair da casa de Hardy, o casal expressa sua vitória com uma demonstração de cumplicidade e, nesse momento, presenciam Watts chorando. Finalmente Keith percebe que Watts o ama em segredo, relembra várias cenas em que ela demonstrou seu amor, descobrindo que a pessoa amada estava todo esse tempo ao seu lado. Tendo como base os aprendizados que obteve ao longo 
da jornada do herói, decide correr atrás dela. Ele não termina com a garota popular, o que difere este filme de outros onde o amor é vertente principal da mudança. Amanda, feita a jornada, decide ficar sozinha pelos "motivos certos", devolvendo os brincos de brilhante que foram dados à pessoa errada. É dessa forma que Keith retorna ao seu mundo comum com o elixir: os ensinamentos que a jornada lhe proporcionou e, junto a isso, "alguém muito especial" - sua amada.

\section{Diversão e subversão na jornada juvenil}

Em seu mais famoso filme, Curtindo a vida adoidado, Hughes elabora os motivos que levam alguém à popularidade, salientando a dimensão de personalidade. Ferris Bueller é o sujeito mais popular do colégio. Amado por todos, menos por seu diretor, que o persegue durante todo o filme na busca vã por desmascarar sua falsa doença. Apesar de todos os artifícios de obtenção de popularidade destacados acima, ele não é um exemplo de "popular" no sentido clássico. Não é rico, tampouco é alto, atlético ou excepcionalmente belo. Ele é popular por sua atenção aos outros, e seu lugar na hierarquia escolar vem mais de sua conduta em relação à vida do que suas posses. Sua extrema popularidade talvez advenha do fato dele subverter completamente os poderes estabelecidos (seja menosprezando o currículo escolar, enganando seus pais ou driblando o diretor). Ele é por excelência uma encarnação dionisíaca da vida adolescente e do bem viver característico do conceito pós-moderno da época da feitura do filme. Representação viva do que é o comportamento jovem esperado: completamente avesso à disciplina. Não por acaso Ferris é espelho, tanto para os demais personagens quanto para nós - o que se evidencia com o diálogo que estabelece conosco ao quebrar a quarta parede e falar diretamente com a câmera. 
No início do filme, quando Ferris consegue enganar seus pais e ficar em casa, ele começa a planejar seu day off, e para tanto conta com o auxílio (compulsório) de seu melhor amigo, Cameron. É esse personagem que nos chama a atenção, pois apesar de não ser o protagonista do filme, é quem vive a jornada do herói preconizada por Vogler. Na cena que nos apresenta Cameron, podemos ver um sujeito depressivo, hipocondríaco e extremamente submisso - que constantemente cede às vontades dos outros, seja dos pais, seja a de Ferris. Deitado na cama, Cameron canta "When Cameron was in Egypt's land... let my Cameron go!" Apesar de parecer pouco importante, essa cena traz consigo uma pista de como se estabelece sua relação com seu amigo popular, já que a música é uma versão de "Go Down Moses", de Louis Armstrong, uma famosa canção estadunidense cantada por afro-americanos remetendo a sua condição de ex-escravos. Na versão original, a letra parafraseada por Cameron diz "When Israel was in Egypt's land: Let my people go". A passagem bíblica na qual Moisés liberta a população judia escravizada no Egito Antigo é uma alusão à escravidão negra. É interessante notar que Cameron se coloca na frase no lugar ocupado originalmente por populações escravas, judeus ou afro-americanos. Fica evidente que ele vê a si mesmo como alguém sem vontade própria e paradoxalmente, tal qual Moisés na Bíblia, é libertado ao longo do filme pela pessoa que anteriormente ocupa o status de escravizador, Ferris.

Como seu melhor amigo, possivelmente seu único amigo, Bueller pressiona Cameron constantemente a fazer algo que ele foge durante todo o filme: divertir-se. Essa diversão pressupõe uma confrontação com os poderes adultos estabelecidos, especialmente seus pais. Apesar de sua relutância, Cameron demonstra grandes picos de felicidade com as picardias elaboradas por Ferris, e são precisamente estas brincadeiras do amigo que levam Cameron à confrontação compulsória com os adultos repressores. Ele não 
pode mais fugir da responsabilidade de falar com os pais sobre seu dia e sobre o uso do carro de estimação do pai. E é isso que o liberta. Durante todo o filme Cameron conserva uma fisionomia preocupada e só é feliz quando está com Ferris, participando da vida próspera do amigo. Quando o carro de seu pai fica irremediavelmente danificado, vemos em Cameron um semblante quase aliviado. É daí que vem sua libertação, somente assim ele completa sua jornada do herói. Segundo a construção de outros filmes e pelos padrões de sociabilidade tradicionais, Cameron poderia ser enquadrado como popular. Diferentemente de Ferris, é rico, alto, bonito e tem carro próprio. Em seu caso, entretanto, todos estes artifícios não fazem dele alguém especial, provavelmente em função da forma de conduzir sua vida e de sua submissão aos outros.

Cameron não é o único a passar por uma jornada. Assim como ele, Jeannie, a irmã de Ferris, é uma personagem que desde o início se mostra rancorosa e invejosa do status e da vida do irmão. Durante sua incessante cruzada por desmascará-lo, ela vai aos poucos vivendo com mais intensidade, mata aulas, desacata policiais, "briga" com Rooney (o diretor), é levada para a delegacia e se apaixona por um delinquente juvenil. No final do filme, Jeannie tem a oportunidade de finalmente mostrar aos pais, objeto de disputa de afeto, as mentiras de seu irmão, mas ao contrário do que se poderia esperar, ela demonstra seu "amadurecimento" e o amadurecimento de sua relação com Ferris, quando o auxilia a enganar Rooney. É pertinente frisar que a jornada de aprendizado preconizada por Jeannie seja consolidar a cumplicidade juvenil frente ao mundo adulto.

Curtindo a vida adoidado contesta com muito mais ênfase do que os outros filmes analisados os tipos clássicos padronizados. Isso vale para os estereótipos elaborados por Vogler, já que os personagens vivem jornadas paralelas, simultâneas e nas quais 
a complexificação do roteiro exige olhar para o "herói errado" Ferris não passa pela jornada, ele já está pronto. Acima de tudo, o filme contesta os tipos destacados por Ortner, já que Ferris não possui os signos necessários para se enquadrar no tipo "popular": ele gosta de arte, tal qual Keith, gosta de música clássica e antiga, não é atlético nem rico, tal qual Duckie, mas mesmo assim ele é "O popular". O filme traz a perspectiva de que alguém pode ser popular sendo "apenas" ele mesmo, ainda que de forma excêntrica e manipuladora. Na sua vida perfeita, só faltava mesmo um carro. (O socialismo europeu não é menosprezado apenas como conteúdo de disciplina escolar).

O consumo, o amor e a amizade são referenciais essenciais para a distinção social e para a construção da identidade juvenil. Um dos principais marcadores de popularidade masculina, em conformidade com o imaginário estadunidense mais amplo, são os carros. Para as garotas, o repetido brinco de brilhante é indicativo de como a popularidade feminina está calcada na beleza - a qualidade do panorama que oferecem. Como narrativas multifacetadas que permitem simultaneamente contestar e reforçar padrões, os filmes de Hughes oferecem exemplos de rapazes populares que não têm carro (sendo Ferris um dos principais exemplos) e garotas pobres, belas e com senso estético aguçado (como Andie em Garota de rosa shocking). As reiteradas contestações aos limites das hierarquias de prestígio são, possivelmente, parte do motivo para o enorme sucesso alcançado pelas obras de Hughes, indicando forte sensibilidade para as vivências juvenis. Ainda mais significativo do que contestar a sociabilidade adolescente, talvez seja dar vazão ficcional para a sua existência, reconhecendo o universo high school como legítimo e profundo o suficiente para encenar jornadas de heróis e heroínas, fazendo da própria juventude uma estrela de cinema. 


\section{Referências}

BERGER, John. Modos de ver. Rio de Janeiro: Rocco, 2001.

BISKIND, Peter. Como a geração sexo, drogas e rock'n'roll salvou Hollywood: Easy Riders, Raging Bulls. Rio de Janeiro: Intrínseca, 2009.

BOURDIEU, Pierre. Razões Práticas: sobre a teoria da ação. In: Espaço social e espaço simbólico. Rio de Janeiro: Francisco Alves, 1992.

BULMAN, Robert C. Hollywood goes to High School: cinema, schools, and American culture. New York: Worth Publishers, 2005.

CAMPBELL, Colin. A ética romântica e o espírito do consumismo moderno. Rio de Janeiro: Rocco, 2001.

CHRISTIE, Thomas A. John Hughes and eighties cinema: teenage hopes and American dreams. Kent: Crescent Moon, 2009.

CLARCKE, Jaime (ed.). Don't you forget about me: contemporary writers on the films of John Hughes. New York: London: Toronto: Sydney: Simon Spotlight Entreteinment, 2007.

GORA, Susannah. You couldn't ignore me if you tried: the Brat Pack, John Hughes, and their impact on a generation. New York: Three Rivers Press, 2010.

MARTÍN-BARBERO, Jesús. Dos meios às mediações: comunicação, cultura e hegemonia. Rio de Janeiro: Editora UFRJ, 2001. 
MORIN, Edgar. As estrelas: mito e sedução no cinema. Rio de Janeiro: José Olympio, 1989.

MULVEY. Visual Pleasures in Narrative Cinema. In: BRAUDY, Leo; COHEN, Marshall. (eds.). Film Theory and Criticism: Introductory Readings. New York: Oxford UP, p.837-848. 2004.

ORTNER, Sherry B. Burned like a tatoo: high school social categories and American culture. Ethnography, London: New Delhi: Sage Publications, p.115-148, mar., 2002.

VOGLER, Christopher. A jornada do escritor: estruturas míticas para escritores. Rio de Janeiro: Nova Fronteira, 2006. 


\title{
Democracia en imágenes. Fantasmas y esperanzas en los relatos electorales de la Argentina contemporánea (1983-2011)
}

\author{
Mercedes Calzado
}

\section{Introducción}

En épocas electorales, los spots de campaña se despliegan como escenas mediatizadas de la política. En ellos es posible relevar lo políticamente decible y pensable, los puntos sensibles de un momento histórico. Y si fijamos la mirada en la especificidad de las campañas presidenciales, nos topamos con fronteras, pasajes y continuidades entre el imaginario político de una época.

El fin de este trabajo es reflexionar sobre los significados de la violencia, el riesgo y el orden en las construcciones de las imágenes electorales a través de la búsqueda de huellas discursivas en las campañas audiovisuales de los candidatos presidenciales. Transitamos las propuestas de los candidatos vencedores en Argentina desde el retorno de la democracia en 1983 hasta la última elección en 2011. Ellos son Raúl Alfonsín (1983); Carlos Menem (1989 y 1994); 
Fernando de la Rúa (1999); Néstor Kirchner (2003) y Cristina Fernández (2007 y 2011).

En estas siete campañas perseguimos vestigios discursivos sobre el conflicto y sus modos de resolución en el imaginario político. A la vez, consideramos las modalidades retóricas de interpelación a una ciudadanía configurada como víctima de un peligro que debe ser neutralizado por las promesas de los candidatos. Con este conjunto de elementos, esbozamos un primer mapa diacrónico de la economía de las imágenes de los riesgos contemporáneos y sus modos de resolución.

El supuesto que atraviesa estas páginas es que en las sociedades de seguridad el sujeto político interpelado es el ciudadano-víctima. Víctima de la inseguridad ciudadana, víctima de las políticas oficialistas, víctima de la acción de la oposición, ciudadanos-víctima de un riesgo que debe ser neutralizado por las promesas de campaña. En momentos de conformación del discurso electoral, emergen rasgos del paradigma de la victimización (PITCH, 2003) y se revitaliza el Estado como el espacio institucional de salvaguarda a un ciudadano desprotegido ante el riesgo económico, la violencia social y la violencia delictiva.

Exploramos la pictoricidad de la historia reciente a través de un recorrido por superficies textuales capaces de arrojar las huellas de la discursividad política. Significantes que permiten localizar regularidades insertas en las formaciones discursivas (FOUCAULT, 2002; FABRI, 2000) desde las cuales alcanzaremos conjeturas interpretativas. Un análisis diacrónico sobre las campañas de los candidatos ganadores cuyo fin es bucear sobre sus similitudes y diferencias, sin dejar de lado el modo en que se incorpora el contexto en el texto (WITHE, 1992). Somos consientes del escueto recorte de este trabajo y de la importancia de avanzar en un análisis comparativo entre candidatos vencedores y perdedores en cada una de estas 
elecciones. Pero avanzamos aquí en un primer mapeo que esperamos alcance mayor exhaustividad analítica en nuevos trabajos.

\section{En campaña}

¿Por qué analizar spots? Las publicidades de campaña funcionan como puntos nodales; son escenas contemporáneas de la política en las cuales se revelan fijaciones de sentido de manera contextual y parcial. En ellos son asibles algunos de los significados contingentes de un momento político. Porque entendemos, como lo hace Laclau (2000); (LACLAU; MOUFFE, 2004), que el discurso no es una totalidad suturada, sino un conjunto de posiciones diferenciales en las que se pueden reconocer las regularidades de un momento histórico. Los spots develan lo políticamente decible y pensable de una época. En sus tramas se manifiesta una coyuntura social, histórica y cultural de la que ella misma es modelo. Es en la historia, y por la historia, donde se pronuncia el imaginario social; un magma de significaciones (CASTORIADIS, 1999) compuesto por imágenes y lenguajes; una creación continua que se define y reestructura en su tiempo.

Si las nuestras, siguiendo a Agamben (2008), son democracias consensuales, democracias de la opinión pública, debemos asumir el desafío de relevar el modo en que los medios construyen las escenas y lenguajes políticos contemporáneos. En este sentido, la mediatización de la política debe ser revisitada a partir de las particulares estéticas audiovisuales actuales y las líneas temáticas que entran en juego, en especial en una elección presidencial.

Los relatos de campaña poseen una dimensión relacional cuyo efecto de sentido debe ser considerado contextualmente. Las publicidades políticas utilizan recursos argumentativos que intervienen para realzar definiciones morales y juicios sobre el entorno. En 
política lo que se dice debe ser leído en el contexto de lo que dicen $y$, de hecho, las propuestas de intervención de campaña se materializan argumentalmente sólo en la disputa entre los enunciadores (VERÓN, 1987; 2001).

Nuestro recorrido persigue las huellas discursivas que nos revelen los riesgos. ¿Por qué centrarnos en las enunciaciones sobre el peligro y los modos de intervenir sobre él en momentos de campaña? Creemos que en las imágenes de campaña se vislumbran centralmente riesgos y esperanzas. Sus trazos recuerdan los fantasmas que nos quitan el sueño; pero también son escenas que narran nuestros sueños, nuestros deseos. La pictoricidad en la que se mueven los candidatos, el entorno que construyen alrededor de sus propuestas, bosqueja el modo en que diagnostican los escenarios sociales y se definen modalidades de intervención.

En este entramado, los riesgos son realidades virtuales; como asegura Beck (2000), que se comprenden en tanto una percepción de haciéndose real. La percepción cultural y la definición pública construyen qué se entiende por peligro. Es decir, los riesgos expresan las definiciones culturales y los estándares de una vida tolerable o intolerable. En nuestras sociedades de seguridad (FOUCAULT, 2000) es la previsión la condición fundamental para el gobierno de las poblaciones. La protección se convierte, de esta manera, en el imperativo categórico de la gestión política.

Por eso, en la modernidad el conocimiento del peligro es la base perceptiva central sobre la cual el Estado debe intervenir en su rol de oráculo capaz de vaticinar el futuro sin errores. El Estado se legitima a través de la percepción social acerca de su capacidad de protección y reproducción de la vida. Los dispositivos de seguridad insertan los conflictos en una serie de acontecimientos probables. Sin embargo, como el control no puede ser absoluto, se produce una percepción de hipertrofia de los aparatos de seguridad 
(ESPÓSITO, 2005), la protección termina siendo uno de los mayores riesgos y ello lleva a reducir el umbral de sensibilidad sobre los potenciales agresores, a la vez que debilita la legitimidad del Estado.

El peligro se percibe cotidianamente como incontrolable. No obstante, las campañas presidenciales son el momento de diagnosticar los riesgos, tanto como hacer reaparecer el lugar de un Estado capaz de aquietar el temor. La política resurge como la dimensión del sueño y de la esperanza que rearma al Estado en tanto espacio desde el cual es posible alcanzar las previsiones sobre el futuro.

\section{Hacia una economía de los riesgos contemporáneos}

Sin desconocer la dificultad de elaborar categorizaciones que simplifiquen un diagrama histórico complejo como el que implica más de 25 años de la historia desde el retorno de la democracia en Argentina en 1983, trabajamos en las próximas páginas a partir de cinco momentos desde los cuales diagramamos un mapa de la economía de los riesgos contemporáneos. Construimos estos territorios a partir de cinco fantasmas que recorren cada etapa electoral Argentina: el fantasma del autoritarismo; el fantasma de la crisis; el fantasma de la corrupción y de la inseguridad y el fantasma del pasado.

\section{3 y el fantasma del autoritarismo}

"Se va a acabar, se va a acabar, la dictadura militar". Con este slogan, los cánticos de los manifestantes en 1983 despuntan sus voces por sobre el sonido de las sirenas militares que resuenan desde fondo. Así comienza uno de los spots más reconocidos de la campaña de 1983 del candidato radical Raúl Ricardo Alfonsín, 
triunfador sobre el líder del Partido Justicialista (PJ), Ítalo Luder. ${ }^{70}$ El riesgo, como se revive en los trazos de la serie audiovisual del Partido Radical (UCR), se edifica sobre el fantasma del autoritarismo, del terror de una dictadura militar (en el poder desde 1976) que la democracia vendría a superar.

En la parte posterior de la toma, una imagen oscura sólo se detiene por una nube ennegrecida (Imagen 1). Por sobre las tinieblas, se abre una puerta que proyecta un halo de luz que ilumina levemente la penumbra del presente. La metáfora de la claridad al final del camino recuerda un presente de miedo y un futuro de esperanza.

Imagen 1 - "Más que una salida electorales es una entrada a la vida"

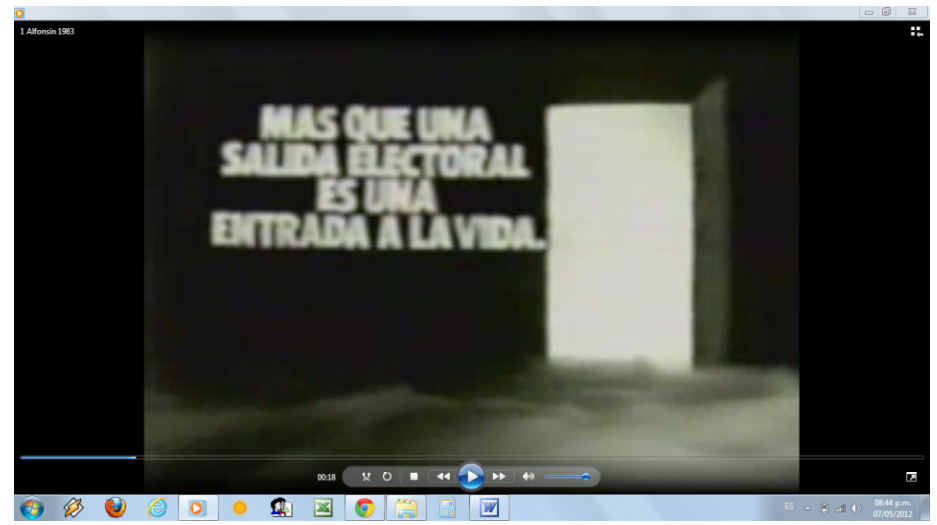

Fuente: Spot de la campaña electoral de Raúl Alfonsín de 1983, dirigida por David Rato.

70 Raúl Alfonsín (UCR) triunfa en las elecciones presidenciales de 1983 con el 51,8 por ciento de los votos contra el 40 por ciento de Ítalo Luder (PJ) y el 2,3 por ciento del tercer candidato fuerte en disputa, Oscar Alende, del Partido Intransigente (PI). Véase: (BORRINI, 2005). 
"Más que una salida electoral, es una entrada a la vida". Detrás de la nube negra se franquea una puerta en la que se percibe un albor. El presente es temor y el mañana es esperanza. El porvenir es el ingreso a la vida. Una actualidad de muerte, oscuridad y desesperación. La toma atraviesa la puerta y deposita al espectador en un acto político del Partido Radical. Ingresamos a la escena junto a una muchedumbre que parece renunciar al miedo con el flameo de sus banderas partidarias. Es la política triunfando sobre el terror. Las banderas, como se ve en otro de los spots de la misma serie, están primero presentes en un acto político que realizado en un espacio interior. Al cambiar la escena, la imagen muestra a la multitud ya no en un estadio sino en una calle céntrica de la Ciudad de Buenos Aires (Imagen 2). El relato revive el paso de la política desde un territorio privado a la esfera pública.

Imagen 2 - Colores del Partido Radical

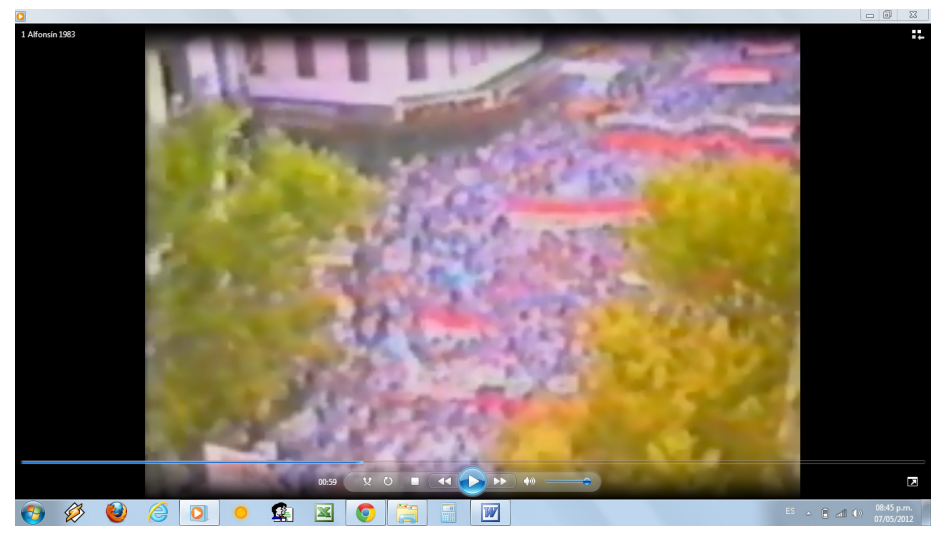

Fuente: Spot de la campaña electoral de Raúl Alfonsín, 1983.

La política irrumpe en la ciudad, franquea el riesgo y arrebata los espacios públicos hasta entonces vedados a la multitud. La oscuridad de los primeros momentos de los spots se transforma en 
luminosidad, en miles de cabezas tomadas desde el cielo. El color del exterior, del día, vence a las penumbras de la noche. La multitud es roja y blanca, lleva los colores del Partido Radical; el gentío está rodeado de árboles verdes, de vida. Son cientos, son miles que llegan a las puertas de la Casa de Gobierno para hacerla suya.

En el off del video, Raúl Alfonsín recita el eslogan de gobierno construido a partir del preámbulo de la Constitución Nacional Argentina: "Para nosotros, para nuestra posteridad y para todos los hombres del mundo que quieran habitar suelo argentino". Un fragmento de la Carta Magna que desprende de sus marcas una configuración especial del nosotros como ciudadanía argentina. También se recupera el retrato de un futuro posible que tapona el camino de muerte instaurado por el gobierno militar. La posteridad es posible para los sobrevivientes del terror. Cuando el candidato caracteriza a "todos los hombres del mundo" acentúa el horizonte de posibilidad de la pluralidad política: todos los hombres y mujeres "que deseen habitar suelo argentino". La geografía nacional deja de ser ajena y un lugar de muerte, vuelve a ser un espacio para todos los exilados que debieron abandonar su país. Un territorio que, en tanto se habita, puede ser vivido.

El candidato se define como la garantía de libertad y justicia, dos significantes amplios de democracia. Entra en juego una figura de argentinidad capaz de superar el oscuro patriotismo militar. Alfonsín se transforma en una marca nacional y cada una de sus películas concluye con un óvalo formado por la bandera argentina y la sigla " $R A$ ". Las iniciales del nombre del candidato se confunden con el inicio de dos palabras centrales en el discurso político de la época: "RA" es o bien "República Argentina", o bien "Raúl Alfonsín". La marca país es la marca del candidato.

Un fragmento más de la Constitución alimenta otro spots: "Para luchar para constituir la unión nacional, consolidar la paz interior, afianzar la justicia, proveer a la defensa común, promover el 
bienestar general y asegurar los beneficios de la libertad". El futuro es liberación y el pasado es autoritarismo. Por encima de las tinieblas se abre un futuro esperanzador en el cual el candidato anuncia:

Su hijo, mis hijos, mis propios nietos, los hijos de todos, necesitan tener las mismas oportunidades. Para eso hace falta más presupuesto en educación. Yo afirmo que esta es una cuestión de decisión y de ganas. Entremos juntos a una Argentina en la que va a ser más importante la primaria obligatoria que el servicio militar obligatorio. (Raúl Alfonsín, candidato a Presidencia da Argentina).

La educación, el porvenir y la formación son las herramientas con las que se combaten las armas. La pluralidad, la libertad por sobre la muerte y el autoritarismo militar. "Ahora Alfonsín", cierra la campaña del radical. El miedo debe ser vencido ahora, el miedo puede ser vencido ahora.

\section{9 y 1995: El fantasma de la crisis}

"Ante este caos, lo único que nos puede dar miedo es que Menem no gane", dogmatiza una publicidad del Partido Justicialista. La elección presidencial de 1989 está atravesada por el temor a la hiperinflación. Una de las mayores crisis económicas de la historia Argentina se había desatado casi un año atrás y la inflación fue su principal protagonista. Carlos Saúl Menem, el candidato del Partido Justicialista, se enfrentaba con el radical oficialista Eduardo Angeloz. ${ }^{71}$ El locutor argumenta la postura opositora al gobierno de turno:

71 En la elección de 1989 Carlos Menem (PJ) obtuvo el 47,5 por ciento de los votos; Eduardo Angeloz (UCR) el 37 por ciento y quien se consagró como tercer candidato 
Dijo Angeloz: ese es mi gobierno, es el Partido Radical el que está en el gobierno y yo soy radical. En estos seis años el gobierno radical no ha hecho nada contra quienes viven del esfuerzo y el trabajo ajenos. Los planes para controlar la inflación resultaron ser tres fracasos, que sólo beneficiaron a los especuladores... la sociedad tuvo que defenderse por sí misma de la indiferencia oficial. Indiferencia que golpeó con mayor dureza en los sectores más indefensos. Ante este caos, lo único que nos puede dar miedo es que Menem no gane. (Eduardo Angeloz, radical oficialista na política Argentina)

Los spots de campaña realzan definiciones morales y juicios políticos sobre el entorno. El axioma moral de Menem se centra en que los especuladores son incapaces de ganar la batalla a los indefensos. La enunciación política sobre el que se ascienta el relato opositor es la indiferencia del gobierno radical para controlar la inflación, el fracaso de sus planes y la defensa autónoma que debió asumir la sociedad ante la ineficacia estatal. En la coyuntura de 1989, el riesgo que acompaña la campaña es la elección de un candidato equivocado. El futuro presidente debe ser un guía de tormenta. "Hay que fijarse bien, para no elegir chicatos". Un fragmento que alude directamente a Angeloz, quien usaba anteojos, y comprueba que los radicales no sólo produjeron la crisis sino que están imposibilitados por ser cortos de vista para asumir el timón en la tempestad. "Menem Presidente. Para que vuelva la alegría", cierra otro spot con una sonrisa ilustrada sobre la pantalla. Los niños, los dibujos animados, el carnaval, la calle. Todos rasgos con los cuales se superaría la crisis hasta reconstruir el horizonte de futuro.

fue el miembro de la Unión de Centro Democrático (Ucedé), Álvaro Alsogaray, con el 6,9 por ciento. 
El miedo por la inflación y por la corrida del dólar deviene a su vez burla. En otra de las publicidades más reconocidos de 1989, el actor cómico Carlos Perciavalle se coloca la vestimenta de Benjamin Franklin y enuncia los miedos desde el interior de los márgenes de un billete de 100 dólares (Imagen 3):

Los tengo muertos. Cuidadito con trabajar, jeh! Los quiero a todos pendientes de mí.... A ver si se avivan que en este país está todo por hacerse. Lo que me pone verde es que Menem va a ganar. $\mathrm{Y}$ con este asunto de la revolución productiva, no me van a dar más bola.

La voz en off cierra el parlamento: "Por un cambio que nos favorezca a todos, Menem Presidente".

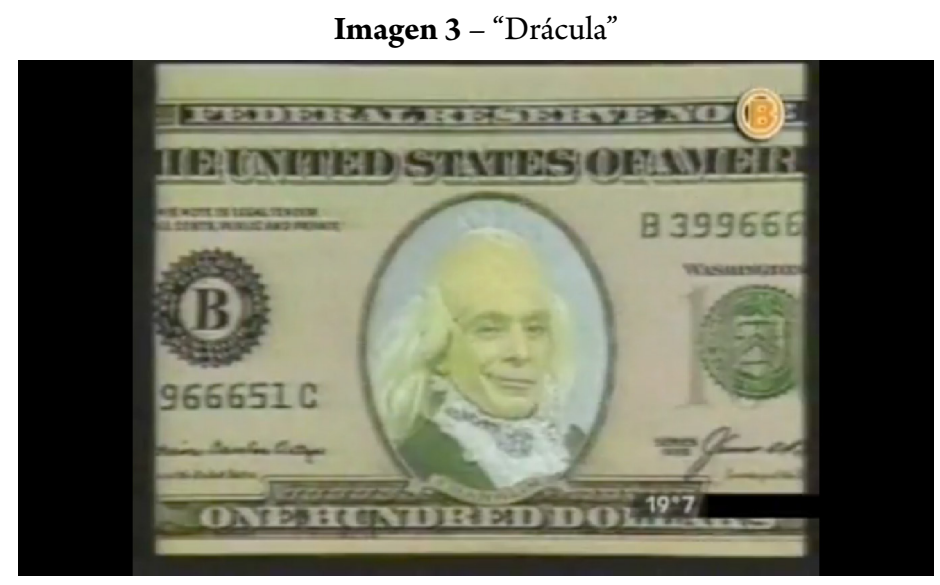

Fuente: Spot de la campaña electoral de Carlos Menem de 1989 producida por "Equipos de Difusión". 
El candidato ostenta el semblante de quien tiene la habilidad para avanzar sobre las tinieblas y conjurar el peligro: "Vivimos tiempos difíciles pero vamos a salir adelante". Menem diagnostica el escenario, propone ilusiones y vuelve a colocar una luz en el horizonte.

Otro rasgo trascendental de esta elección es el trabajo que realiza la campaña del candidato vencedor con el miedo al desorden y a la violencia que su figura y el Partido Justicialista podrían provocar. En la publicidad titulada "Drácula", nuevamente Carlos Perciavalle se coloca un traje cómico: "Primero fue el viejo de la bolsa... Luego vino el lobo feroz. El cuco de hoy se llama Carlos Saúl Menem (risas). No se deje engañar. Sigana Menem, todos los chupasangre nos vamos del país. Piénselo (risas)". Y el locutor clausura el spot: "Porque ya no somos niños, el 14 de mayo vamos a cambiar la historia". La campaña negativa del candidato radical es revisada en clave cómica por el justicialismo. El significante miedo está en disputa. Pero el temor que hegemoniza la campaña es la crisis económica, y su principal protagonista la inflación.

Menem se vuelve a presentar como candidato en 1995, luego de una reforma constitucional realizada en 1993 que le permite la reelección. La crisis económica seguía habitando el imaginario popular y la campaña justicialista renueva su apuesta al fantasma de la debacle económica. Algún tiempo antes de la elección, el "modelo económico" es metaforizado por el equipo de campaña de Menem con una Ferrari. En un episodio muy conocido durante su primer mandato, a Menem le obsequian una Ferrari que muestra a todos los medios de comunicación e, incluso, conduce por sí mismo a Mar del Plata. El radicalismo toma este episodio como símbolo de la frivolidad del Presidente, y en 1993 crean un spot al que luego el menemismo contrapone otro anuncio televisivo (Imagen 4). La publicidad justicialista exhibe distintas partes del vehículo mientras una voz en off describe las funcionalidades del vehículo: "Poder basado en la estabilidad, luz roja a la inflación, puertas cerradas al proteccionismo estatal, libertad 
para criticar, créditos para el techo propio. No dejes que te la vendan cambiada. Seguí con el mismo modelo. Votá para adelante".

Imagen 4 - "Ferrari auténtica"

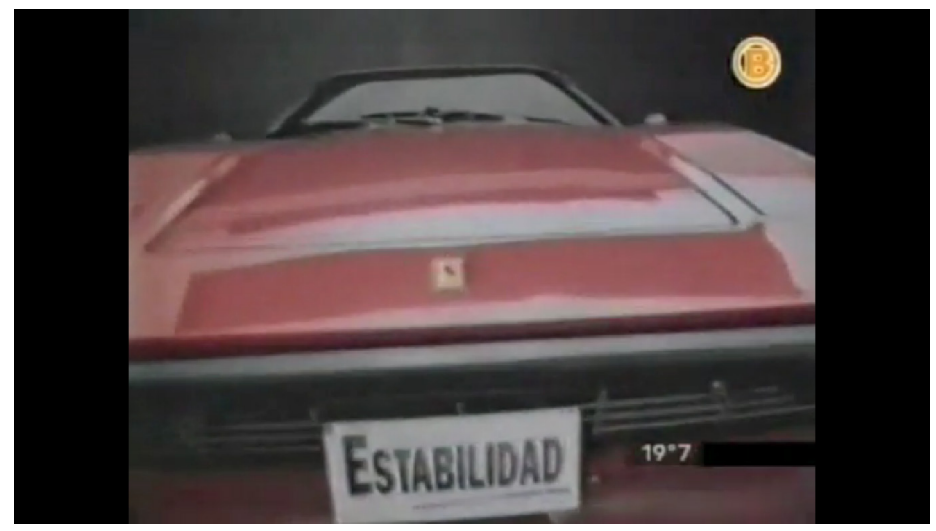

Fuente: Spot de la campaña electoral de Carlos Menem (1993) creado por Ayer Vázquez.

El riesgo virtual que confronta la campaña menemista es la vuelta al pasado. La crisis y la hiperinflación de 1989 resuenan aún en la memoria popular. En una de las películas de campaña más recordadas de 1995, luego de una salida al cine, un grupo de jóvenes discute en un bar sobre los candidatos y refresca los peligros cercanos:

A. Y... ¿buena la película, no?

B. Sí, pero no nos salgamos del tema.

A. Y, ¿qué querés? Todavía no sé a quién voy a votar.

B. No puedo creer que todavía sigas dudando. La hiper(inflación). Las demarcaciones. ¿Ya te olvidaste? ¿Y tu hermano?, ¿que no va a tener que hacer la colimba? Ahora hay créditos. ¿O cómo te compraste el departamento? Ahora hay estabilidad.

A. Sí, ¿pero el efecto tequila? 
B. ¿El efecto tequila? Pará, pará. Imaginate esta crisis sin Menem, sin el plan económico, sin la posibilidad de que haya reelección.

En una reelección la dificultad de emular los riesgos se revela en la imposibilidad de ubicar el eje del peligro por fuera de la propia esfera de influencia de la gestión gobernamental en marcha. En la continuidad de Menem, el riesgo sigue siendo la crisis pero convertida en un peligro presente a través de la debacle financiera internacional de mediados de los noventa. Si el timón sigue bien agarrado por el Presidente, el "Efecto tequila" no ingresará. Menem es la figura imaginaria del garante para que la estabilidad presente siga siendo una dimensión futura.

\section{9: El fantasma de la corrupción y el fantasma de la inseguridad}

"Voy a ser el que empuje a la cárcel a cada delincuente, a cada corrupto", garantiza el candidato radical. En una de las publicidades más repetidas de la campaña de 1999, De la Rúa camina firme bajo el frío acompañado por jóvenes armados, cual paramilitares, sin uniforme ni militar ni policial (Imagen 5). En 1999 Fernando de la Rúa, candidato radical por una amplia alianza con sectores progresistas, gana la elección frente al líder del Partido Justicialista, Eduardo Duhalde. ${ }^{72}$ Había pasado una década desde el primer triunfo de Carlos Menem, dos presidencias consecutivas y un imaginario que había cobrado fuerza, sobre todo entre los sectores urbanos medios: la corrupción era el principal problema contra el

72 Fernando de la Rúa, candidato de la Alianza, se impuso con el 48,37 por ciento de los votos, mientras que Eduardo Duhalde, por el PJ, se quedó con el 38,27 por ciento. Tercero se ubicó Domingo Cavallo (Acción por la República) con el 10,22 por ciento. 
que debía intervenir un nuevo gobierno. Pero, a su vez, comenzaba a ser relevante un tema que desde el retorno democrático no había aparecido como un conflicto central para la opinión pública: la inseguridad urbana. Sobre la base de estos dos problemas, el candidato construye una figura de ética y fortaleza para combatir los dos fantasmas de finales de la década del noventa.

\section{Imagen 5- "Miedo"}

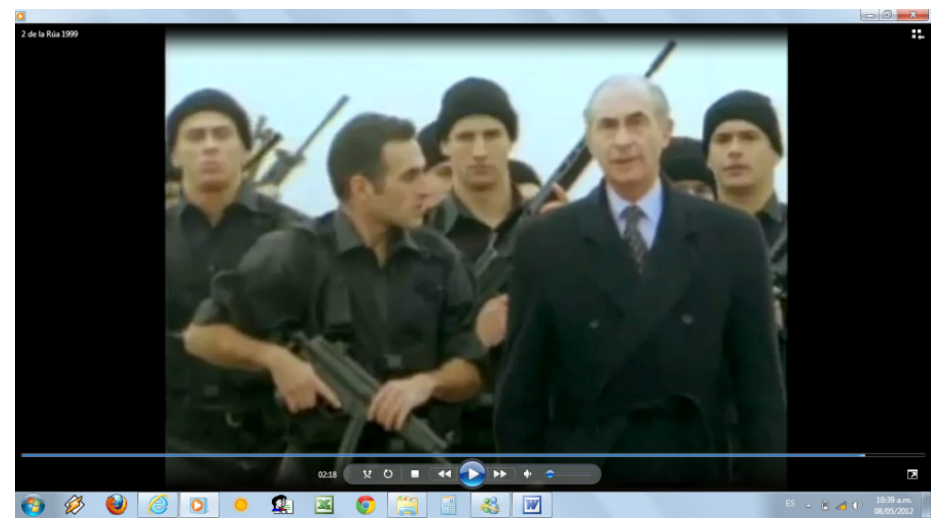

Fuente: Spot de la Campaña de Fernando De la Rua de 1999, producido por el equipo a cargo de Carlos Souto y Ramiro Agulla.

Parece ser tiempo de decir basta. "¿Alguien quiere seguir con esto?", se pregunta una voz en off mientras se suceden imágenes de desocupación, dolor, inseguridad; retratos de la crisis. Dos mujeres se abrazan y lloran (Imagen 6). Los sonidos de fondo clausuran un montaje de miedo: vientos de soledad, sirenas de violencia, risas de corrupción.

El peligro acecha en la oscuridad. Por eso el candidato, en varias de las publicidades, camina al aire libre entre tonos verdes, en medio de la naturaleza. Cuadros de llanura, fotografías de 
montañas. El verde de la vegetación, el marrón de la tierra y el azul del cielo recuerdan el horizonte posible de libertad.

Desde su perfil ético, el candidato responde a la pregunta del locutor: "Yo no quiero (seguir con esto)". Y agrega como parte de sus propuestas de campaña: "Por eso voy a crear tribunales de impuestos para que juzgue y manden a la cárcel sin demora a los grandes evasores". De la Rúa define su camino, mientras recorre la senda cotidiana de cualquier ciudadano en medio de las góndolas de un supermercado. Está entre gente trabajadora, y no quiere más impunidad, quiere justicia y, por qué no, castigo. Son películas que apelan constantemente al recurso de la verosimilitud, a la tipicidad de la retórica política: el candidato transita los espacios cotidianos junto a nosotros, como cualquier ciudadano va al supermercado y es consciente de la realidad en la que vivimos. Nos habla a través de los spots. La verosimilitud se utiliza en tanto módulo imaginativo, se aplica para evocar en el espectador momentos vividos, conversaciones previas, pensamientos en los que alguna vez buceó.

Imagen 6 - Retratos de la crisis

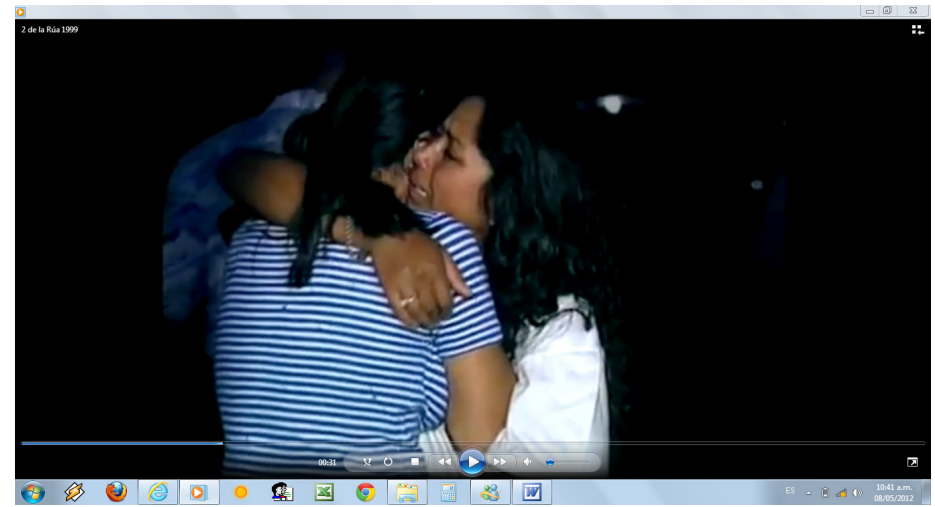

Fuente: Spot de la Campaña de Fernando De la Rua de 1999, producido por el equipo a cargo de Carlos Souto y Ramiro Agulla. 
De la Rúa engloba los miedos virtuales en otro tramo de su campaña: "Tres cosas que quiero que queden claras de la Argentina que viene: el que las hace las paga, la Argentina va a acrecer, conmigo el ajuste lo hace la política y no el pueblo. Ah, conmigo un peso un dólar". El compromiso del candidato es básicamente uno: "Como presidente me comprometo a privilegiar el respeto y a hermanar al pueblo argentino más allá de los colores políticos".

La campaña interpela a la clase media como ciudadanía-víctima. Uno de los spot más comentados durante aquellos años exhibe a un hombre que se dispone de espaldas a la cámara. "Hola soy Pablo, y salgo así porque debo tener cara de estúpido. Nos vieron cara de estúpidos". Se da vuelta y, junto con su mujer, fija su ojos en los ojos del espectador: "El 24 de octubre, vamos a volver a mirar hacia delante en la Argentina". El porvenir es posible, recuerda un Pablo que podría ser cualquiera de nosotros.

Una alumna de un colegio público rinde examen (Imagen 7). El pizarrón marca el tema de evaluación: "Argentina, Nación". La profesora pregunta: "Y si la Argentina es un país rico, ¿por qué el pueblo es pobre?". La joven responde: "Y, por los corruptos". La maestra repregunta: "¿Y qué son los corruptos?". La niña no duda: "Son las personas que le roban el trabajo y la plata a la gente". Cualquiera puede describir el terror que azota la Argentina menemista, incluso una niña de ocho años. La corrupción es un tema que recorre las mesas familiares. La maestra cierra su interpelación con un último interrogante: "Entonces, ¿qué necesita la Argentina?". Esta vez la nena duda, pero responde como si fuera una consecuencia lógica del razonamiento que viene planteándole su docente, como si estuviera ante un cálculo matemático: "Un presidente que no sea corrupto". 
Imagen 7 - "Un presidente que no sea corrupto"

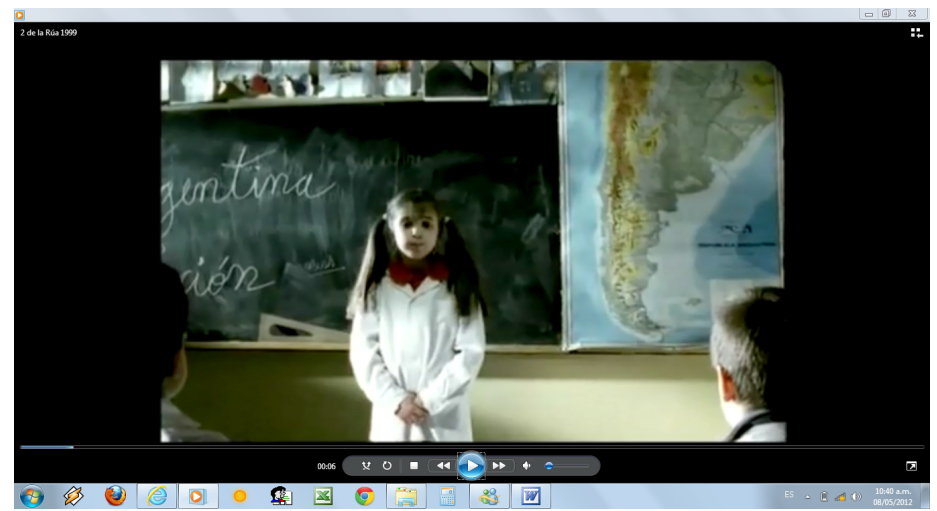

Fuente: Spot de la campaña de Fernando De la Rua de 1999, producido por el equipo a cargo de Carlos Souto y Ramiro Agulla.

De la Rúa erige su figura presidencial desde un marco moral. "Dicen que soy aburrido. Aburrido: Será que no manejo Ferraris. Será para quienes se divierten mientras hay pobreza". Las palabras del candidato radical en otro spot recuerdan la especulación, la jocosidad, la perversión de la desigualdad del modelo menemista. Y mientras recupera la fotografía de una casa pobre de alguna parte de la Argentina, sentencia: "No quiero un pueblo sufriendo mientras algunos pocos se divierten. Quiero un país alegre, quiero un pueblo feliz". La moral arremete contra la corrupción. La felicidad y la codicia de unos pocos se contraponen a la felicidad de todo el pueblo. El futuro reaparece ya no sobre las tinieblas del autoritarismo militar, sino sobre la violencia de la criminalidad y la corrupción representada en torno del menemismo: "Quiero la dignidad que tuvimos, la que perdimos, la que vamos a volver a tener". "Voy a ser el Presidente de una Argentina distinta, eso el lo que voy a ser". Luego de la inmoralidad, volver a ser. 


\section{3-2011 - El fantasma del pasado}

"Usted no lo conoce demasiado, porque es nuevo, no pertenece a la generación política del fracaso". "Anda tranquilo por la calle, quiere a su familia, no miente, hace lo que dice, es tal como lo ves". En 2003 el peligro que recorre las pantallas en época de campaña es el pasado de crisis y de corrupción. Muy cerca resuenan las cacerolas, las protestas y las muertes que sentenciaron a la Argentina en 2001. Muy cerca Néstor Kirchner, el candidato poco conocido del Frente para la Victoria, arremete contra la corrupción a través de la figura de su principal oponente en las elecciones: Carlos Menem. ${ }^{73}$

"Todos vamos a notar la mejoría, pero sin ostentación, vamos a trabajar tan silenciosamente como hasta ahora". Kirchner convierte su debilidad en virtud. No lo conocemos, parece decir, porque no formó parte de la fastuosidad, trabajó en su provincia como cualquiera de nosotros. $\mathrm{Y}$ hoy, como todos los ciudadanos, quiere un país en paz.

El riesgo virtual de 2003 es nuevamente la crisis. Ahora, el candidato vencedor se esgrime como aquél que posee el saber para enfrentar las dificultades: "Tomó su provincia muy endeudada, pagó, ahorró y hoy Santa Cruz tiene el menor índice de desocupación y los más altos salarios". Conoce la gestión porque estuvo a cargo de un Estado provincial, por eso "tiene equipos, tiene planes y sabe gobernar". Tiene "1800 profesionales". Viene "trabajando durante más

73 Los dispersos resultados de la primera vuelta, que fueron definitivos debido a la renuncia de Menem a competir en el ballotage por calcular que sería perdedor en la segunda vuelta, fueron los siguientes: Carlos Menem 24,45 por ciento; Néstor Kirchner 22,24 por ciento; Ricardo López Murphy 16,37 por ciento; Alberto Rodríguez Sáa 14,11 por ciento; Elisa Carrió 14,05 por ciento, y Leopoldo Moreau 2,34 por ciento. 
de dos años en 40 ciudades de la Argentina. Tenemos -agrega- una radiografía detallada y exhaustiva de todas las actividades". Porque: "es imposible administrar lo que no se conoce". El entorno trazado por las imágenes es el de un país con dificultades que demanda un candidato con saberes técnicos para enfrentar los riesgos pasados, que aún resuenan en el presente. Desde aquí, reaparece la territorialidad del porvenir: "Un día vamos a decir que con Kirchner pudimos mejorar el futuro de nuestros hijos".

La línea temporal y argumentativa de Kirchner en 2003 prosigue en la candidatura oficial de Cristina Fernández cuatro años más tarde. ${ }^{74}$ Su campaña en 2007 se construyó sobre claras referencias al pasado reciente y a la esperanza que germina de las cenizas. "Dolores Argentina, la nena que nació el día en el que todos queríamos morir" es uno de los spots más representativos de esta etapa. En la película una cigüeña atraviesa la pantalla con una recién nacida. Franquea las movilizaciones populares de 2001, supera el helicóptero del Presidente que se escapa de la Casa Rosada en 2001, logra trasponer el humo negro y la represión (Imagen 8).

74 En la elección de 2007 Cristina Fernández de Kirchner por el Frente para la Victoria obtuvo el 45,4 por ciento, y Elisa Carrió por la Coalición Cívica el 23 por ciento. Roberto Lavagna, por la Concertación Una Nación Avanzada, ocupó el tercer lugar con el 16,9 por ciento. 


\section{Imagen 8 - "Dolores Argentina"}

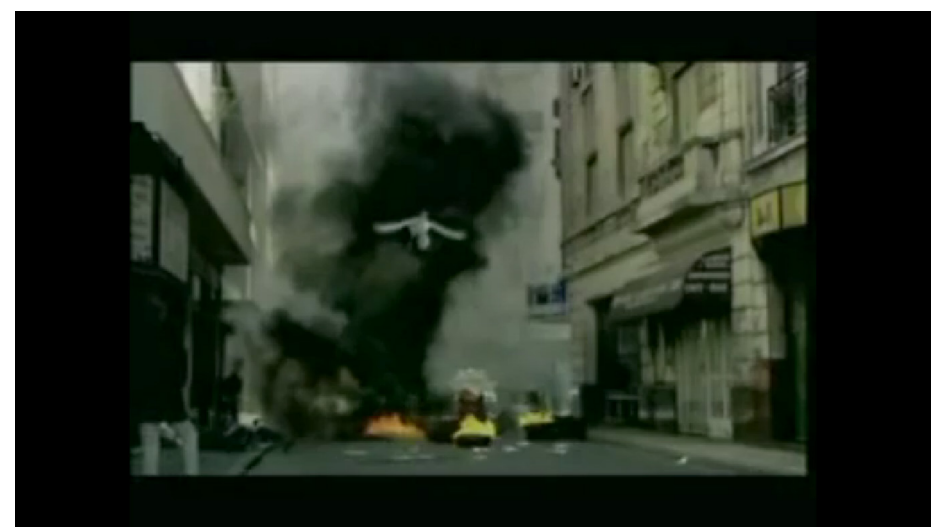

Fuente: Spot de la Campaña de Cristina Fernández para la elección de 2007.

El spot recurre a la ficcionalización y el espectador se reconoce en los personajes típicos de su narrativa, en el entorno propuesto por el argumento. Los personajes funcionan como "tipos", como casos individuales, son figuras capaces de sustituir nuestras experiencias; funcionan como modelos que expresan la vida del receptor. El padre, ansioso, recibe a Dolores en el mismo momento en el que está viendo aterrado por televisión al helicóptero de Fernando de la Rúa salir de la Casa de Gobierno, como todos nosotros lo vivimos pocos años atrás. Al escuchar el llanto de su hija recién nacida, su preocupación se convierte en alegría.

El spot continúa el relato. La crisis llega incluso a impedir que el padre inscriba a la niña en el registro civil. "En algunas cacerolas abolladas la gente empezó a cocinarle", apunta la líder de la Asociación de derechos humanos Abuelas de Plaza de Mayo, Estela Carlotto, apoyando la campaña de la futura Presidenta. El miedo de los padres, señala el relato, era que sus primeras palabras fueran 
Patacones o Lecop, haciendo referencia a las monedas paralelas al peso que funcionaron en Argentina durante los años de la crisis. Pero la nena dijo: "Mamá, como todos los chicos". Y así, "Dolores Argentina aprendió a sumar antes que a restar". "Hoy Dolores Argentina es una chica normal". La normalidad. "Cada vez la llaman más Argentina y menos Dolores" y "lo más importante es que siga creciendo en paz". La paz enfrenta y vence a un pasado de turbulencias. La anormalidad de la crisis se debilita frente a la normalidad de la estabilidad. Un país que suma y que no resta. Un presente estable que arremete contra un pasado de anarquía y dolor.

En "El casco", otro spot de la elección de Cristina Fernández, se recuperan las imágenes de desocupación, de falta de futuro; ambas parecen seguir el presente de cerca. Pero son reseñas de historias enfrentadas por una actualidad en la que prevalecen la esperanza y la recuperación de la dignidad. En la publicidad, un desempleado consigue trabajo y con su nuevo casco va al colegio de su hija a mostrarse como un trabajador, como todos los otros padres. El spot cierra: "Recuperamos la dignidad de tener un trabajo". Otra publicidad recupera el argumento de cambio: "Los argentinos llevamos siglos de peleas, desencuentros y violencias. Es hora de que esa misma historia nos una". La historia, el pasado, un fantasma que aún persiste en el imaginario actual, en las discusiones cotidianas. Un ente que atemoriza desde el ayer y al que hay que seguir enfrentando.

En 2011 Cristina Fernández se encuentra en plena gestión presidencial y con las encuestas a favor para que prosiga un segundo mandato. ¿Cómo se configuran los riesgos para el espacio político que está en el cenit del Estado y se supone que la misma candidata que se presenta a la elección está controlando? Como Menem en 1994, y de alguna forma también como en la transferencia entre la presidencia de Néstor Kirchner y Cristina Fernández, ella es una candidata que gestiona los riesgos de la actualidad. ¿Pero cómo 
dimensionar este peligro desde un presente estable? Las palabras del spot de Cristina Fernández de Kircher titulado "Atilio", cuenta una historia a través de un protagonista "de carne y hueso" y nos ayuda a pensar en este dilema:

Trabajé en un astillero hasta principios de los noventa. Después tuve el peor trabajo que nadie puede tener: buscar trabajo. Uno me dijo: "estamos buscando alguien con menos experiencia". Yo le dije: ¿Qué hago, vuelvo tres años antes? Llegué a sentirme en el fondo del mar. Un día suena el teléfono de casa y me dicen: "Don Atilio, venga mañana al astillero, se está reactivando todo y lo necesitamos. Y acá estoy, haciendo submarinos. Hoy enseño a los jóvenes todo lo que aprendí y lo primero que digo es "aprovechen, muchachos, que soplan otros vientos". Estamos haciendo historia. (Las palabras del spot de Cristina Fernández de Kircher, 1994).

Atilio cuenta su historia. La mayoría de los spots de la candidata del oficialismo apelan a categorías vitales, a historias singulares que se transforman en cercanas, en plausibles.

Desde estas historias se delinea un eje en el que la actualidad es progreso, y el progreso es futuro: "Estamos haciendo submarinos". Los relatos están narrados en tiempo presente. "Hoy hemos incorporado a más de 10 millones de argentinos a los beneficios de la jubilación", asegura Cristina Fernández en otra publicidad. "Hoy quiero anunciar que quiero extender esta Asignación Universal por Hijo a las mujeres embarazadas".

El hoy es esperanza. La crisis es pasado. "Los noventa" son el momento del desempleo, una época donde desaparece el horizonte vital del trabajo: "Me sentí en el fondo del mar", recuerda Atilio. La 
crisis circula, sin dudas, pero es un fantasma no tangible, es un miedo del ayer. El hoy es "reactivación". La crisis no desaparece como categoría posible, más bien se apela a ella como un silencio actual, como un recuerdo vívido, material; como una pesadilla del ayer. "Hoy soplan otros vientos". "Hoy -asegura Atilio-, estamos haciendo historia".

Mientras que los partidos opositores recurren a una dimensión contemporánea del peligro y definen al contexto presente como riesgoso, la longitud temporal de un gobierno que procura un nuevo período es el progreso. Un presente de mejoras, de expansión, de profesionales, con perspectivas de empleo, de futuro. Cristina Fernández representa la continuidad en esta actualidad exitosa y en este futuro promisorio que se encuentra sólo a pocos pasos. El miedo es del ayer. El pulso del imaginario contemporáneo lo marca la esperanza, la apelación al sueño, no a la pesadilla.

\section{Entre el riesgo y el futuro}

En sus publicidades, los candidatos trazan escenarios que estimulan momentos vividos, pensamientos individuales, discusiones cercanas. Sus narrativas son módulos imaginativos que evocan fantasmas presentes y esperanzas futuras. En estas discursividades, el pánico es un factor fundamental. El temor es un elemento constitutivo de la política, asegura Hobbes(2007); y un componente fundamental del gobierno del Príncipe, según Maquiavel(2006). Son pavores que revelan la arcaicidad de lo moderno: ser mortales en la modernidad es ser sujetos del temor. Y esta percepción de peligro sólo parece ser resuelta por la discursividad de un Estado protector; un Estado activo capaz de intervenir en la gestión de la alarma colectiva. Ahora bien, cuando se debilita la figura de 
protección estatal, nada mejor que las narrativas de campaña para recordar la sustancialidad simbólica de su potencialidad protectora.

Pero el miedo atesora múltiples rostros. En este trabajo exploramos los miedos a los que apelaron las elecciones argentinas desde el regreso de la democracia. En la pictoricidad de los spots de campaña de las elecciones entre 1983 y 2011 se entreven peligros contextuales que la figura del candidato procura enfrentar. El fantasma del autoritarismo en 1983, el fantasma de la crisis en 1989 y 1994, el fantasma de la corrupción y la inseguridad en 1999, y el fantasma del pasado entre 2003 y 2011. Cada candidato construye su figura y los riesgos que asumirá como jefe de gobierno desde el enfrentamiento enunciativo con los otros contrincantes. A la vez, configura el perfil de sus interlocutores y los modos de interpelarlos.

Para conquistar elecciones, la política exhorta muchas veces a través de experiencias de violencia en las ciudades; pero este no es necesariamente el temor que se delinea en las narrativas de las campañas de los últimos 25 años en Argentina. En la encuesta de opinión realizada por el grupo Latinobarómetro en 2011, se afirma que la inseguridad fue una prioridad para el electorado latinoamericano. Asegura, de hecho, que en la gran mayoría de las campañas de la región del período la problemática de la seguridad fue central en las agendas de discusión política. El caso argentino es paradigmático ya que el problema de la inseguridad ingresa como una preocupación fuerte a mediados de la década del noventa. Sin embargo, desde el comienzo de la última etapa democrática la violencia urbana se constituyó como un problema para la población urbana (véase KESSLER, 2010). Ahora bien, como hemos ido recorriendo a lo largo de estas páginas, que la seguridad se convierta en un eje primordial de discusión pública desde 1983 en adelante, no necesariamente implica que se instale como una dimensión sustancial de las campañas presidenciales. 
El momento en que sin dudas la preocupación sobre la seguridad se cristaliza en los discursos de los candidatos triunfadores es en 1999, año en que la circulación de noticias sobre la seguridad se instala fuertemente en la opinión pública argentina. De todas maneras, como hemos ido caracterizando, el peligro de lo inseguro es un elemento de alguna manera marginal a la hora de construir narrativas de campañas presidenciales. De esta forma, la definición social de riesgo que se observa en los relatos electorales asume múltiples dimensiones que manifiestan diversas coyunturas históricas y culturales.

La recorrida por las campañas arroja otro dato interesante: el uso del riesgo configura un tipo de ciudadanía atravesada por la victimización. Víctima del autoritarismo, víctima de la crisis económica, víctima de la corrupción y la violencia urbana, víctima del pasado reciente. Si bien en 1983 la ciudadanía es definida como activa y se renueva la sensación de una espacialidad pública colectiva, su modo de entenderla es, a la vez, como un nosotros hombres y mujeres que en el pasado reciente fueron víctimas de un Estado autoritario. El paradigma de la victimización ingresa en la batalla discursiva de la política electoral. La ciudadanía debe recuperar la protección que otrora le otorgara el Estado Nacional. Un pasado imaginario de protección del peligro, un pasado ideal de amparo estatal, de resguardo de la vida. Un tiempo contemporáneo, en cambio, percibido por la ciudadanía como amenazador. Lo temible se desplaza por doquier, y el Estado debe reasumir su moderno compromiso de protección. Los candidatos se mueven en la arena de disputa buscando amparar a una ciudadanía victimizada por la alarma y el riesgo. Ellos representan la quimera del retorno del rol central de protección del Leviatán. El ciudadano-víctima, plasmado en las imágenes como un sujeto estático, vuelve a ser resguardado por la agilidad e impulso de un candidato que busca el cenit del Estado como un espacio capaz de restituir una estabilidad señalada como en vertiginosa degeneración. 


\section{Referencías}

AGAMBEN, Giorgio. Che cos'è il contemporaneo? Nottetempo, 2008. Tradução de Vinícius Nicastro Honesko. Chapecó - SC: Argos, 2009. (em português: O que é o contemporâneo? e outros ensaios).

. Signatura rerum. Sul Método. Torino: Bollati Boringhieri, 2008.

BECK, U. Retorno a la teoría de la sociedad del riesgo. Boletín de la A.G.E, n.30, p.9-20, 2000.

BOURDIEU, P. El campo político. La Paz: Plural, 2001.

BORRINI, A. Cómo se vende un candidato. Un siglo de campañas políticas en la Argentina. Buenos Aires: La Crujía, 2005.

CASTORIADIS, C. La institución imaginaria de la sociedad. Buenos Aires: Tusquets, 1999.

ESPÓSITO, R. Inmunitas: protección y negación de la vida. Buenos Aires: Amorrortu, 2005.

FOUCAULT, Michel. A arqueologia do saber. Rio de Janeiro: Forense Universitária, 2002.

. O que é um autor? Trad. José A.Bragança. São Paulo:

Paisagens, 2000.

Seguridad, territorio y población. Buenos Aires: Fondo de Cultura Económica, 2006. 
HOBBES, T. Leviatán. Buenos Aires: FCE, 2007.

KESSLER, G. Entre el terrorismo de Estado y la inseguridad. Delito urbano y política en la transición democrática, En: GARGARELLA, R.; MURILLO, M.V. ; PECHENY, M. Discutir Alfonsín. Buenos Aires: Siglo XXI Editores, 2010.

LACLAU, E.; MOUFFE, C. Hegemonía y estrategia socialista. Hacia una radicalización de la democracia. Madrid: Siglo XXI Editores, 2004.

MAQUIAVELO, N. El príncipe. Buenos Aires: Claridad, 2006.

PITCH, Tamar. Responsabilidades Limitadas. Actores, Conflictos Y Justicia Penal, Buenos Aires: AdHoc, 2003.

. El género de la seguridad urbana. Universidad de Perugia, 2008.

VERÓN, E. La palabra adversativa. Observaciones sobre la enunciación política. In: AAVV. El discurso político. Buenos Aires: Hach, 2001.

WHITE, John Kenneth. Responsible party government in America. Perspectives on political Science, v.21, iss. 2, p.80-90, spring 1992. Disponível em: < http://www.apsanet.org/ pop/APSA1950/ White1992.html $>$. 


\section{Manchetes assustadoras: a construção social do medo entorno de um caso de violência sexual}

Jimena Maria Massa

Uma figura aparentemente indomável, recriada como fortemente ameaçadora e onipresente, foi a protagonista da extensa cobertura jornalística do caso publicamente conhecido como "o estuprador serial de Córdoba” (Argentina), referente a um homem que estuprou $93^{75}$ mulheres nessa cidade. A discursividade midiática construída em torno da criminalidade - habitualmente exibida como muito próxima dos cidadãos - incorporou, neste caso, durante os quatro meses de cobertura, a temida figura do "estuprador"

75 Cifra informada na época por fontes do Poder Judiciário de Córdoba e citada no livro La marca de la bestia (2005), cuja edição é posterior à cobertura utilizada para esta pesquisa. No entanto, existem dúvidas a respeito da existência de outros casos não denunciados, e de mais alguns que foram denunciados, mas não provados.

76 Cada vez que "estuprador", "estuprador serial" ou "o serial" aparece entre aspas significa que estou utilizando uma categoria nativa; trata-se das expressões presentes no discurso jornalístico para se referir ao homem que estuprava as mulheres e cuja identidade era ainda desconhecida. 
sempre apresentada como um perigo iminente e irredutível, especialmente para as mulheres.

Mientras (o estuprador) no cometa un error, seguirá habiendo pánico en la ciudad (LA VOZ DEL INTERIOR, 23.10.2004).

Mientras el e-mail que escribió la última víctima del violador serial sigue dando vueltas por Internet y enmudeciendo a quien lo lee, ayer se conocieron detalles de un nuevo ataque sexual cometido contra una joven estudiante en la Ciudad Universitaria de la Capital (LA VOZ DEL INTERIOR, 07.10.2004).

\section{Um estuprador na capa do jornal}

"O serial" ganhou de maneira definitiva as páginas dos jornais argentinos quando, em setembro de 2004, começou a circular massivamente um e-mail escrito por uma universitária de 20 anos, autoidentificada com o nome fictício de Ana, que denunciava ter sido estuprada na rua por um homem desconhecido. Na sua mensagem, ela contava que poucos dias antes, na noite de 28 de agosto, ia ao encontro de amigas quando foi atacada por um homem que a surpreendeu pelas costas e, sob a ameaça de "cortá-la inteira", obrigou-a a entrar num prédio abandonado, onde foi estuprada na escuridão.

Com um modus operandi similar, Marcelo Sajen, durante muito tempo conhecido apenas como "o serial", estuprou dezenas de mulheres - a maioria estudantes universitárias - enquanto conseguia escapar da intensa perseguição policial. Quando estava prestes a ser preso, atirou na própria cabeça na via pública, diante dos agentes policiais da operação que finalmente o agarravam. Mas esse 
desenlace, ocorrido em dezembro de 2004, esteve precedido por meses de pânico social, que se tornou evidente - entre outras formas - nas manifestações de rua organizadas pelas vítimas, pedindo maior eficiência do Estado na perseguição - prisão do "estuprador".

Em Córdoba, a segunda cidade em importância da Argentina, com 1,5 milhões de habitantes e uma média de $900^{77}$ delitos sexuais (denunciados) por ano, a denúncia de Ana provocou um impacto singular: uma potente combinação de susto coletivo, solidariedade espontânea e indignação popular. Por um lado, não era comum que uma mulher divulgasse um drama dessas características, sobretudo, considerando o silêncio que envolve grande parte dos crimes sexuais. Por outro, ela afirmava que o estuprador era "o serial" que já tinha cometido vários crimes na mesma zona, e levantava a suspeita de se tratar de um policial ou de alguém com proteção policial.

Além dos detalhes sobre os fatos acontecidos naquela noite como foi abordada pelo homem, qual foi o trajeto que realizaram juntos, que tipo de comentários ele fez - o relato de Ana pretendia chamar a atenção e promover ações destinadas a conseguir a prisão do estuprador. Não foi apenas um desabafo; foi uma denúncia concreta, repleta de elementos para o início (ou continuação) de uma investigação policial e um contundente protesto contra os organismos estatais responsáveis por erradicar a violência sexual e atender às vítimas.

Desde então, o tema adquiriu um status diferente, começou a captar a atenção permanente do jornalismo, e a informação fragmentada e esporádica que vinha sendo publicada se tornou um

77 A cifra é uma média das denúncias de violência sexual registradas nos anos 2006, 2007 e 2008 na Unidad Judicial de la Mujer y el Niño de Córdoba, criada em 2005, logo depois do caso do "estuprador serial". O número indica a quantidade de delitos efetivamente denunciados em Córdoba, e não inclui os casos da chamada "violência doméstica" ou "familiar”. Não existem estatísticas oficiais do ano 2004. 
assunto de interesse público e presença midiática constante. As primeiras matérias já permitem perceber uma das características do caso, recriada inúmeras vezes durante a cobertura: a incrível astúcia de um homem "perverso" que acossa uma sociedade imaginada como indefensa e atemorizada. A ideia de estar perseguindo um delinquente sagaz que conseguia burlar qualquer cerco se consolidou durante os meses posteriores, ao ritmo das novas - e estéreis - medidas instituídas para capturá-lo. Trata-se, segundo a retórica midiática, de um risco incontrolável que deixa os leitores vulneráveis à fatalidade.

Un violador serial, que tiene en jaque a la sociedad de Córdoba desde hace dos años, volvió a atacar en esta ciudad $[\ldots]$ El fiscal general de la provincia, Gustavo Vidal Lascano, pareció rendirse ante la evidencia: como con la Policía parece no alcanzar, le pidió a la gente que los ayuden a capturarlo. "Es francamente dificultoso llegar a este hombre $[\ldots]$ ”. La historia del caso le da la razón. Once hombres fueron detenidos en el último año por parecerse al identikit [...] Todos fueron liberados: su $\mathrm{ADN}$ no coincidía con el del violador. (CLARÍN, 18/09/2004).

$[\ldots]$ ustedes saben que estas personas son desviados psiquiátricos y además tienen una actividad perversa. No estamos ante un delincuente convencional. Son tipos que planifican, se preparan para producir hechos tan terribles como son las violaciones. Y no resulta fácil agarrarlos, ni acá ni en ningún lugar del mundo (do governador de Córdoba, José Manuel de la Sota; LA VOZ DEL INTERIOR, 19/09/2004). 
O continuum de notícias, informes e opiniões veiculado pela mídia fortalece o caráter intangível e onipresente das ameaças, ativando rapidamente o que Rossana Reguillo (2009) chama de "a causa eficiente" dos medos. A autora se refere ao dispositivo por antonomásia utilizado pela mídia na sua "temível vocação simplificadora". As violências existentes, diz Reguillo, unidas ao "trabalho da imaginação" (APPADURAI, 1994) e às retóricas dos meios, detonam um medo amorfo, criando uma atmosfera onde prevalece a ideia de uma "cidadania sitiada".

No entanto, se o caso foi paradigmático em virtude da quantidade de episódios de violência de gênero que abrangeu, também o foi pelos diversos processos e relações que gerou ao seu redor. Longe de permanecerem paralisadas, e ainda sentindo medo, muitas pessoas - sobretudo, mulheres - mobilizaram-se para conseguir a prisão de Sajen e, de forma mais geral, para lutar contra a violência sexual. Ana e um pequeno grupo de amigas - o mesmo grupo que aquela noite a acompanhou para fazer a denúncia policial e que depois organizou uma série de ações de mobilização pública - formaram a associação civil "Podemos hacer algo", que ainda hoje trabalha em Córdoba no atendimento às vítimas da violência sexual.

A partir da quebra do silêncio por parte de Ana, outras jovens decidiram "falar" e progressivamente foi se configurando um estado de denúncia coletiva que derivou, no epílogo do caso, em concretas mudanças institucionais: a criação da Unidad Judicial de la Mujer y el Niño, instituída em Córdoba logo após o desenlace do caso como resposta às reivindicações das mulheres que sofreram os estupros, é apenas um exemplo dessas mudanças.

Nesse contexto, o discurso jornalístico, ao invés de aparecer como o habitual "intruso" que violenta a intimidade das vítimas, pareceu identificar-se com o drama das mulheres abusadas, outorgando-lhes visibilidade e reivindicando a sua luta. E na construção 
midiática desse "evento crítico" (DAS, 1995), junto com a (re)criação de diversas representações de gênero e das violências ${ }^{78}$, o medo teve um protagonismo singular. Esse tópico foi construído através de múltiplas informações em torno da criminalidade e da chamada (in)segurança urbana, mas também apareceu como resultado de outras linhas de sentido que perpassaram a cobertura: a consideração do estupro como um sofrimento repentino e como quebra do cotidiano, a caracterização das mulheres ao mesmo tempo como vítimas e corajosas, e a representação do homem a partir de imagens animalizadas ou patologizadas.

\section{Etnografando (em) textos e contextos}

Por se tratar de uma prática significante na produção do discurso dos meios de comunicação operam condicionamentos ligados às relações de poder e, como tal, é um tipo de discurso socialmente legitimado para classificar, delimitar e interpretar. Assim, define lugares sociais para homens e mulheres, produzindo e reproduzindo aquilo que seria o próprio de cada sujeito segundo sua adscrição genérica, ao mesmo tempo em que marca limites e novas possibilidades de ação.

A análise do discurso jornalístico torna-se, então, fundamental para se conhecer como funciona essa estrutura simbólica hierarquizada que condiciona as relações de gênero (com as violências derivadas $)^{79}$, e também para entender como se construíram algu-

78 A análise da discursividade midiática em torno das diferenças de gênero e as violências é o foco da minha dissertação de mestrado, "Saiu no jornal: a construção da violência de gênero no discurso midiático sobre 'o estuprador serial' de Córdoba (Argentina)”, PPGAS, UFSC (2010), orientada por Carmen Silvia Rial.

79 Para a análise deste caso de violência sexual, situo-me no campo dos estudos de gênero (SCOTT, 1990; BUTLER, 2003) e, mais especificamente, na área de estudos 
mas das novas significações que este evento específico produziu. Por sua vez, foi através desse discurso que se concretizaram determinadas modalidades de ação que deram visibilidade ao caso, com as respectivas respostas por parte do Estado. Ainda mais: várias dessas ações se cristalizaram em e como discurso, pois tal como afirma Stuart Hall (1997), "toda prática social tem condições culturais ou discursivas de existência”.

As ideias aqui apresentadas em torno da construção do medo fazem parte de uma etnografia que inclui todos os textos, fotografias e infografias publicados em Clarín e La Voz del Interior, os jornais argentinos de maior circulação no país e na província de Córdoba, respectivamente, desde 17 de setembro até 31 de dezembro de 2004. São 220 peças, identificadas só nesses dois jornais. A amplitude da cobertura $^{80}$ tem relação com que o considerado impressionante ou terrível, em termos de ruptura a respeito da ordem habitual, resulta sempre matéria-prima noticiável e do tipo que favorece a construção espetacular do relato. Também convém destacar que os acontecimentos que surgem sob a forma do imprevisível não desaparecem instantaneamente da agenda midiática, senão que tendem a desdobrar-se em novos acontecimentos, que formam uma série, permitindo reorganizar a percepção da realidade por parte dos leitores (MARTINI, 2000).

da violência contra as mulheres (GROSSI, 1994, 1998; SEGATO, 1999; MARCUS, 2002; MOTTA, 2006).

80 Considerando apenas os textos veiculados por La Voz del Interior e Clarín durante quatro meses (desde $1^{\circ}$ de setembro até 31 de dezembro de 2004), o tema apareceu na capa dos jornais em 30 edições: 22 de La Voz del Interior e 8 de Clarín. Outro indicador significativo é o número de páginas da Internet em que aparecem juntas as palavras "violador", "serial” e "Córdoba", segundo o buscador Google: 53.200 registros só em espanhol. 
Por sua vez, as características que marcaram o processo de construção deste acontecimento - o imprevisível, o comovente, o terrível - coincidem com aquelas que Veena Das (1995) descreve para os "eventos críticos": momentos em que a violência irrompe no cotidiano da sociedade, provocando um sofrimento percebido como "repentino" e "inexplicável", em que conjuntos de atores que levavam até então uma vida anônima surgem no espaço público interpelando o Estado. Ainda quando a descrição das modalidades (e das consequências) dessa interpelação não seja o foco deste trabalho, é preciso dizer que o caso se tornou um evento crítico não apenas pela violência inesperada inerente aos estupros, mas também pela aparição de novas práticas derivadas da transformação das chamadas "vítimas" em agentes políticos.

Para a análise das linhas de sentido e das principais estratégias discursivas que caracterizam a cobertura jornalística, considero algumas categorias provenientes da Análise Crítica do Discurso (VAN DIJK, 1990, 1998, 2000; FUNCK, 2005, 2006, 2009) e da Teoria dos Discursos Sociais (TDS) construída por Eliseo Verón (1985, 1987, 1987a, 1987b, 1995, 2001, 2004), que concebem os discursos como fenômenos de manifestação espaço/temporal de sentido.

Por sua vez, as premissas foucaultianas sobre "a ordem do dizível” (FOUCAULT, 1990, 1991, 1995, 1996) ${ }^{81}$ funcionaram como o pano de fundo da análise, de forma tal que o discurso aqui é entendido como o resultado de um processo diferencial, relacional, incompleto, instável e aberto. Nesse sentido, a combinação da

81 Refiro-me à noção de discurso entendida como um conjunto de enunciados que ocorrem como performances verbais em função enunciativa, e que constituem objetos de luta, regulados por uma ordem do dizível, definida no interior de lutas políticas. Noção que se insere numa tradição que concebe os jogos de significação de maneira lógica, múltipla, heterogênea e plural. 
análise discursiva com entrevistas realizadas pelos jornalistas autores desses discursos se sustenta na ideia de ir além do texto e ao encontro do contexto; ou seja, ao encontro das redes complexas em que estes textos se inserem e das quais emergem, tal como sugere Carmen Rial (2004).

Finalmente, neste trabalho, a comunicação é pensada nos termos propostos pelos estudos culturais: como uma maneira em que os indivíduos se constroem a si mesmos e as suas relações. Não a partir dos meios, mas das "mediações"; não como mera circulação de informações, mas no seu caráter de "processo produtor de significados” (HALL, 2003; MARTÍN-BARBERO, 1995, 2003). Trata-se, então, de "sair da imanência dos meios e colocá-los na larga perspectiva da cultura” (SCHMUCLER, 2008), entendendo "cultura" como sentido compartido, espaço de consensos, dissensos e conflitos (REGUILLO, 2006).

A escolha de autores que procuram salientar a natureza comunicacional da cultura e a natureza cultural da comunicação se inscreve na linha traçada por outras pesquisas antropológicas também interessadas nos meios de comunicação ${ }^{82}$, que já constituem uma área de pesquisa bastante reconhecida e que poderíamos chamar de Antropologia da Comunicação ou Antropologia da Mídia (SPITULNIK, 1993; DICKEY, 1997; ABU-LUGHOD, 2006; RIAL, 2003, 2004, 2007).

82 Refiro-me aos trabalhos das antropólogas Carmen Rial (2003, 2004, 2007) e Esther Hamburger (2004), entre outros. Para um inventário detalhado das pesquisas antropológicas sobre mídia realizadas no Brasil, ver o artigo de Isabel Travancas (2008). Já sobre pesquisas na área da comunicação que utilizam o método etnográfico, ver os trabalhos de Ana Carolina Escosteguy (2001) e Fabrício Silveira (2006). 


\title{
A gestão de sentidos sobre a (in)segurança urbana
}

\begin{abstract}
Una catarata de desgracias cayó luego de que el gobernador se vangloriava de su política de seguridad. [... T Todos sus discursos fueron arruinados por el asesinato de dos ancianos $[\ldots]$, el asalto a un productor de aceite de oliva [...], el triple crimen en una pizzería $[\ldots]$, así como la aparición fantasmal de un violador serial (LA VOZ DEL INTERIOR, 02/10/2004).
\end{abstract}

A leitura das matérias da época, caracterizadas pelo discurso catastrófico e alarmista, remete ao que Theophilos Rifiotis (1997) define como a crescente extensão do campo semântico da violência, que nos leva a pensar que estamos diante de seu constante e inelutável aumento. Em um contexto repleto de relatos atemorizantes, as informações sobre "o serial” sitiaram as páginas dos jornais, realimentando de forma constante o tópico discursivo da (in) segurança urbana. As notícias sobre furtos, roubos, assaltos, assassinatos e, claro, estupros, cercavam (e continuam cercando) a vida cotidiana dos cordobeses, retratados como submersos no desconcerto e desesperação. E, sobretudo, como sujeitos invadidos pelo medo.

Mientras tanto, los vecinos miran cada rostro parecido al del identikit para desentrañar si detrás de esos ojos están los del violador; o alambran terrenos para evitar que pasen los de otros barrios; o vuelven con la idea de armarse porque murió el hombre que había sido asaltado un mes atrás (LA VOZ IDEL INTERIOR, 24/10/2004). 
Mediante a gestão de sentidos associados ao que se entende como perigoso, incerto, ameaçador ou violento ${ }^{83}$, a mídia administra os imaginários em torno da (in)segurança, ao mesmo tempo em que elabora hipóteses sobre suas possíveis causas, constrói os deveres do Estado, incluídas as leis que seriam necessárias para evitar esse estado de coisas, e até sugere modos de conduta individual para se prevenir da "onda criminosa”. Assim, "a mídia tem um papel destacado na produção de uma cultura específica sobre a violência e a segurança, associada a uma homogeneização das suas múltiplas e diferentes manifestações" (SOARES, 1995, p. 17).

Neste caso, é importante se pensar na violência como uma linguagem compartilhada a partir da qual é possível analisar os limites da sociabilidade, a sua crise e as suas possibilidades (SOARES, 1995), sendo o medo um condicionante cada vez mais presente no convívio urbano. Seja pela adesão a estratégias de maior proteção individual, seja pela distância social e geográfica que a desconfiança no "outro" provoca, a sensação de medo acaba configurando práticas que modificam de forma substantiva hábitos e estilos de vida.

Ando con el pelo recogido y trato de ir sin calzado que tenga tacos, por si tengo que correr. Para defenderme, tengo mi llavero en la mano, es bastante grande y de hierro", dice Liliana, estudiante de Ciencias Económicas.

83 Dentre os diversos significantes veiculados pela mídia que remetem a uma mesma matriz narrativa, aparece a noção de "pobre", ainda que sutilmente colocada, como similar ou equivalente à violência. Segundo Rifiotis (1997), os jornalistas reproduzem a recorrente associação entre crime e pobreza, como uma verdade primordial, reafirmando o mito das "classes perigosas", e a partir desta verdade se cria uma espécie de matriz narrativa capaz de gerar diferentes textos sobre os fatos registrados. 
[... Este año, muchas no cursaron materias de noche y le pidieron a sus padres que las fueran a buscar al salir de clases. Otras empezaron a usar taxis y el servicio gratuito de colectivos que se implementó en Ciudad Universitaria, precisamente para proteger a las estudiantes (LA VOZ DEL INTERIOR, 20/12/2004).

A antropóloga mexicana Rossana Reguillo, que analisa como a mídia propicia narrativas sociais que alimentam imaginários que naturalizam a relação entre violência, insegurança e pobreza, define o medo como "uma experiência individualmente experimentada, socialmente construída e culturalmente compartilhada" (REGUILLO, 2000c, p. 65; [tradução nossa]):

São as pessoas concretas as que experimentam medos; no entanto, é a sociedade que constrói as noções de risco, ameaça e perigo e gera modos de resposta estandardizada, re-atualizando ambos, noções e modos de resposta, segundo os diferentes períodos históricos (REGUILLO, p. 65; [tradução nossa]).

\section{As retóricas do medo: limites e possibilidades}

A discursividade em torno do "serial" oferece múltiplas "retóricas do medo", entendidas como "o conjunto de argumentações eloquentes que buscam persuadir e provocar respostas emotivas, através de tropos e imagens baseadas em juízos e razoamentos não reflexivos, ancorados num princípio de medos expandidos diante de riscos incontroláveis" (REGUILLO, 2010, p. 39; [tradução nossa]). Esses riscos incontroláveis aparecem repetidamente na cobertura midiática sob a forma de um estuprador astuto e inalcançável, capaz de atacar em qualquer momento e em todo lugar. 
[... el violador serial no sólo elige los lugares donde va a someter a sus víctimas sino que realiza un seguimiento previo de la mujer a atacar. (LA VOZ DEL INTERIOR, 23.10.2004)

El violador serial, para Courel (psiquiatra consultado pelo jornal), no tiene en cuenta el deseo del otro. La víctima no le importa como sujeto, sino como medio para saciar su pulsión de hacer sufrir. Su patología es mostrar el poder. "En él la violencia es un estimulante, algo que en su casa tal vez no tiene”, estimó.

(LA VOZ DEL INTERIOR, 25.10.2004).

Esse tipo de discurso pode provocar, entretanto, reações diversas: do recolhimento na intimidade à mobilização pública, incluindo alternativas tais como o armamentismo privado ou a tolerância com a produção política de "zonas de risco zero" (ou seja, a segurança em desmedro dos direitos humanos). Segundo Reguillo (2010), diante das "retóricas do medo", a cidadania parece assumir que não há instituição capaz de protegê-la deste "vírus mortal" que é a insegurança crescente, e então elabora uma variedade de respostas "pré-políticas ou altamente políticas". Ou, como explica Alba Zaluar em Medo do crime, medo do diabo (1994, p. 6), os jornais trazem manifestações de indignação dos moradores atemorizados, "que vivem atrás das grades de suas residências e dos vidros de seus automóveis, conclamando todos para o fim da passividade, sem dizer como fazê-lo".

[... ] la desesperación y la desconfianza de las chicas no cesa y la manía crece.

[...] es raro encontrar chicas solas a la noche. Después de las 21 ó las 22 , muchas se quedan en 
sus departamentos. No van a comprar nada que pueda esperar hasta la mañana siguiente. Cuando salen a bailar, si se pueden tomar un taxi para no caminar dos cuadras a solas y ponerse en riesgo, lo hacen (LA VOZ DEL INTERIOR, 20/12/2004).

No caso em foco, porém, o corpus analisado apresenta alguns exemplos de recolhimento para o íntimo e individual, mas também de estratégias de aliança, solidariedade entre pares e movimentos em grupo. Diante do "risco incontrolável" que o estuprador implicava, as mulheres de Córdoba criaram suas próprias e específicas formas de lidar com o medo.

Se mueven en grupo, en especial para ir y volver de la facultad.

[... Como medios de defensa, las jóvenes poseen en sus carteras cuchillos de cocina, aerosoles de gas de pimienta (los cuales están agotados), una pequeña alarma (ideada en principio para puertas y que pueden conseguir a seis pesos) o bien silbatos (LA VOZ DEL INTERIOR, 20/12/2004).

A profusa circulação de informação em torno do estuprador - "Nadie habla de otra cosa en Córdoba", disse Clarín - teve efeitos concretos no cotidiano de muitas mulheres. Algumas se organizaram coletivamente e criaram o grupo "Podemos hacer algo", que inicialmente se ocupava de exigir a captura de Sajen e depois se tornou uma associação civil que luta contra a violência sexual. Outras se mobilizaram publicamente e participaram das passeatas e dos atos de rua, como foi dito antes. Muitas outras mudaram seus hábitos como forma de se proteger. A cidade dos universitários tinha se tornado "insegura". 
Considerando que todos os estupros cometidos por Sajen foram contra mulheres, espera-se que sejam elas - tal como evidenciam as matérias analisadas - "os sujeitos do medo" (MARCUS, 2002) e, portanto, as criadoras das variadas estratégias de prevenção e as usuárias das tecnologias da segurança. No entanto, é possível que a vulnerabilidade associada às mulheres $-\mathrm{e}$, portanto, o interesse jornalístico pela forma com que elas se protegiam de um eventual ataque - não seja apenas uma consequência da vitimização constante que evidenciam as estatísticas criminais, e sim de um imaginário que atribui ao gênero feminino um medo que lhe seria inerente.

\section{Um medo feminino?}

A socióloga Lucía Dammert (2007) afirma que, segundo a literatura internacional, "o gênero é um dos principais prognosticadores do temor" e que as mulheres sentem mais medo do que os homens ${ }^{84}$. No entanto, por trás desse temor ao delito, há elementos que devem ser considerados, ainda quando tendem a ser invisibilizados. Segundo a autora, a vulnerabilidade às agressões sexuais - diante das quais a probabilidade de as mulheres serem vítimas é pelo menos dez vezes maior que a dos homens - é um elemento que deve ser levado em conta na hora de definir a percepção do risco de ser vítima de uma agressão. Trata-se de uma percepção que, em

84 Em contraposição com a ideia generalizada de que as mulheres sentem mais medo, Eckert (2002) assinala, no contexto de uma pesquisa sobre as vivências de idosos na cidade de Porto Alegre, que são os homens os que padecem de forma mais acentuadados determinantes da nova condição de insegurança e temor à vitimização. "Acostumados que estavam ao aproveitamento do tempo livre da aposentadoria para o convívio em formas de sociabilidade masculina no mundo público (rua), a opção pela restrição maior ao mundo doméstico, torna-se frequente" (Ibidem, p. 16; tradução nossa). 
grande medida, se origina no status de subordinação histórica das mulheres e nas relações desiguais entre ambos os sexos. O temor das mulheres não aparece espontaneamente, senão que é parte de um processo aprendido e socializado.

Numa perspectiva similar, Esther Madriz, autora do livro $A$ las niñas buenas no les pasa nada malo (2001), explica que os diferentes graus de medo da delinquência entre homens e mulheres "podem explicar-se, pelo menos parcialmente, pelas imagens dominantes que mostram divisões estruturais de gênero e apresentam às mulheres como comparativamente vulneráveis, fracas, impotentes e passivas, e os homens como fortes, enérgicos, poderosos e ativos" (Ibidem, p. 30; tradução nossa). Especificamente a respeito da violência sexual, a autora assinala que a maioria das mulheres "experimenta o medo ao estupro como uma persistente e corrosiva sensação de que algo terrível poderia acontecer; uma angústia que lhes impede fazer coisas que desejam ou precisam fazer" (Ibidem, p. 32; tradução nossa).

Entre as mulheres de Córdoba, também se verifica a presença do medo - em alguns casos, inclusive, como um obstáculo insuperável - mas ele nem sempre funcionou como um impedimento para fazer coisas que elas desejavam ou precisavam fazer. Pelo contrário, como foi dito em parágrafos anteriores, a ameaça latente do estuprador foi também um desafio e muitas das jovens desenvolveram criativas estratégias que lhes permitissem, mesmo com medo, continuar suas atividades e rotinas. A seguir, dois exemplos opostos, publicados na mesma edição do jornal:

[...] varias abandonaron la carrera y volvieron a su pueblo porque tenían terror de volver a la Ciudad Universitaria, uno de los lugares predilectos del violador serial. 
[...] También, muchas se están interesando en la práctica de artes marciales, por si el depravado las aborda por detrás. "Además te ayuda a tener carácter y decisión”, comenta Karina, también de Ciencias Económicas (LA VOZ DEL INTERIOR, 20/12/2004).

Além das imagens de vulnerabilidade com que habitualmente as mulheres são retratadas e das comparações de gênero hierarquizadas que a mídia, em termos gerais, produz e reproduz, neste caso se agrega mais um elemento que pode ter sido crucial para a construção do medo das mulheres: a discursividade em torno de Sajen, que durante a cobertura foi recriado como um homem astuto, hábil e indomável, que tinha o poder de surpreender, submeter e provocar dor. Patologizado e animalizado por meio das mais diversas hipérboles e metáforas, a imagem que o discurso midiático projetou do homem foi, efetivamente, atemorizante.

Em contrapartida, para descrever "El peligro que nos rodea" (manchete da matéria reproduzida a seguir) e demonstrar como a existência do estuprador mudou os hábitos de vida das mulheres, o jornal publicou o testemunho de algumas estudantes universitárias:

Siento que todos los hombres que me miran tienen la cara del violador $[\ldots]$ Siempre que voy sola miro para todos lados por temor a que parezca.

No ando más sola. A partir de las noticias sobre el violador, y como salgo tarde la facultad, empecé a organizar mi día desde el horario en que pasa el colectivo. (LA VOZ DEL INTERIOR, 20/12/2004). 
Assim, "a partir de las noticias sobre el violador", o medo se torna uma experiência coletiva, ${ }^{85}$ dominante e imanente que funciona como argumento de controle social. Pois, como explica Reguillo (2000b, 2000c), a enunciação midiática constrói e amplifica o medo, que já não é apenas uma experiência individual, e adquire sua força política na confirmação de uma comunidade de sentido na qual se constroem as noções de risco, ameaça e perigo; geram-se modos de resposta estandardizados e a certeza de um "nós" a partir do qual se interpreta a realidade.

No entanto, e ainda nesse contexto de respostas estandardizadas que o medo provoca, existe aqui um ponto de ruptura: a agência corajosa de um grupo de mulheres; a decisão de falar, a vontade de sair, a força de se manifestar, a valentia de denunciar, a determinação de não ficarem quietas nem paradas. Essas ações também fizeram parte, tanto quanto as expressões de cuidado e recolhimento, das formas de vida desenvolvidas "após o estuprador".

Las reacciones que generó la cadena de correos electrónicos con el relato de una de las víctimas del violador serial quedan como una muestra inobjetable de que, de cualquier manera, la comunidad es capaz de intentar para sí misma una cadena de auto-protección cuando el Estado, como responsable de la seguridad, falla (LA VOZ DEL INTERIOR, 10/10/2004).

85 Ao analisar os espaços societários de configuração das emoções, Mauro Koury (1999) explica que as relações sociais que emergem dos atores expostos a situações de risco determinadas são produto do movimento social ou institucional gerador da crise ou tragédia. "A dor e o sofrer fazem parte da experiência individual dos sujeitos sociais, como processo único e específico, mas ao mesmo tempo compreendido e compartilhado por toda uma coletividade espacial e temporalmente dada" (Ibidem, p. 75-76). 
Referindo-se às formas de socialidade que o medo provoca nas sociedades urbanas contemporâneas, Cornelia Eckert (2007, p. 77) salienta que "não há só evitação, há gestos de transformação nas relações que nos levam paradoxalmente a nos aproximar do outro: uma ONG fundada por vítimas, a necessária corrente de vizinhos e a familiarização com algum outro próximo são pequenas subversões à imagem do indivíduo alienado e sem qualidades". $\mathrm{E}$, tratando-se das mulheres, essas pequenas subversões adquirem outra dimensão, pois a capacidade de assumir riscos também pode ser entendida como um atributo que empodera às mulheres.

Nesse sentido, vale lembrar as reflexões de Tamar Pitch (2008) no sentido de que, para transitar nas cidades contemporâneas, as mulheres não precisam da "esterilização" do terreno urbano, senão de mais recursos sociais, econômicos e culturais que lhes permitam atravessar esse terreno com confiança.

As mulheres de Córdoba, que compartilharam sentimentos de insegurança e vulnerabilidade, recorreram a ações paliativas, mas também desenvolveram suas transgressões e assumiram riscos. "Se há adesão ao gradeamento, se há segregação e afastamento do Outro, estranho, há também motivação de reconhecimento do Outro, há busca de pertencimento, de conformação de redes de interação", explica Eckert (2007, p. 75), procurando dar conta da diversidade de modos de ação e relação que podem conviver ainda num contexto muito atemorizante ${ }^{86}$.

86 A maioria das etnografias sobre o cotidiano urbano desenvolvidas por Cornélia Eckert (2002, 2003, 2007, entre outras) inclui trabalhos de campo realizados em Porto Alegre, uma cidade que, por suas características sociopolíticas e demográficas, é comparável com Córdoba. 


\section{Crônicas atemorizantes e controle social}

La Policía salió ayer a saturar la Ciudad Universitaria y el barrio Nueva Córdoba, las zonas por donde habitualmente actúa el violador serial.

Una sencilla recorrida por los predios de la Universidad servía anoche para comprobar la presencia de móviles del CAP, policías parados en zonas oscuras, parejas de uniformados patrullando y efectivos en bicicleta. Algo similar sucedía en Nueva Córdoba, donde se advertía gran cantidad de móviles policiales con sus luces encendidas (LA VOZ DEL INTERIOR, 07/10/2004).

Em "A notícia como forma de controle social" (2006), Beatriz Marocco e Christa Berger descrevem, numa perspectiva foucaultiana, a mecânica de controle social que atravessa a produção dos discursos informativos. Assinalam que, embora Foucault não tratasse diretamente da notícia, ao caracterizar as instituições disciplinares, referiu-se à vigilância normalizadora que um tipo de imprensa francesa exercia sobre os corpos dos menos poderosos, quando incluía, obsessiva e diariamente, um "inimigo sem rosto", muito próximo, presente em qualquer lugar. Seguindo essa pista, as autoras avançam na ideia de notícia como um instrumento de exclusão social, graças à objetivação da periculosidade de certos indivíduos e das estratégias conjuntas, adotadas entre o jornalismo e outras instituições, para controlá-los.

Essa linha de pensamento permite questionar as representações que nesta cobertura se referem, por exemplo, aos homens trigueños ou morenos, com idades entre os 30 e os 45 anos. Numa operação discursiva que também implica uma interpretação hierárquica das diferenças, as fontes policiais e judiciais (em geral, 
homens brancos) insistiram na identificação do estuprador a partir da cor da sua pele e da sua possível origem em determinada região geográfica, seja esta o norte da Argentina - no limite com a Bolívia - ou a própria província de Córdoba.

Once hombres fueron detenidos en el último año por parecerse al identikit y todos debieron ser liberados al comprobarse que su $\mathrm{ADN}$ no coincidía con el del violador. El episodio más grave fue el de un verdulero que padeció 41 días de prisión y el escarnio público, ya que su identidad y hasta el domicilio de su familia, fue revelado por la Policía a la prensa (CLARÍN, 06/10/2004).

En las últimas horas recuperó su libertad un joven boliviano que había sido demorado por la Policía, a raíz de su parecido físico con el violador serial de Córdoba (LA VOZ DEL INTERIOR; 12/10/2004).

Também numa perspectiva foucaultiana, Daisi Vogel (2009) analisa a missão moralizante e estabilizante do jornalismo - no contexto da sua função docilizante - e em particular a das páginas policiais dos jornais que, com suas narrativas de crimes, "são instrumentos de produção do medo pelos grandes criminosos, tornando assim natural a presença da polícia no meio da população". A autora lembra que, segundo Foucault, no século XIX, como forma de proteção da riqueza na sociedade industrial, houve uma ofensiva de moralização sobre a população destinada a distinguir o povo dos delinquentes que foram definidos como aqueles que são perigosos para todos e quaisquer grupos.

A relação entre os discursos do medo veiculados pela mídia em torno do estuprador e a notável presença policial registrada em Córdoba durante a perseguição de Sajen - apresentada pelo governo 
como garantia de maior segurança para a população - poderia ser entendida, considerando as premissas foucaultianas, quase como uma questão de causa e efeito. No entanto, é importante lembrar que as mediações não funcionam de maneira linear e a mídia não trabalha de maneira autônoma, senão que multiplica e naturaliza discursos já existentes; por isso, nas enunciações midiáticas é possível encontrar as marcas ${ }^{87}$ de imagens e ideias que circulam no social.

Assim, é tão necessário questionar o discurso controlador da mídia, visando identificar seus traços moralizantes ou docilizantes, quanto olhar para a diversidade de vozes que nele aparecem, procurando identificar os jogos interdiscursivos que são colocados em cada caso, já que no discurso jornalístico, tal como acontece com as condutas humanas diante do medo, também há fissuras, deslizes e espaços de resistência.

\title{
Referências
}

\begin{abstract}
ABU-LUGHOD, Lila. Interpretando la(s) cultura(s) después de la televisión: sobre el método. Iconos, Revista de Ciencias Sociales. Facultad Latinoamericana de Ciencias Sociales, Sede Académica de Ecuador, n.24, p.119-141, enero 2006. Disponível em: <http://redalyc.uaemex.mx/redalyc/src/inicio/ArtPdf Red. jsp?iCve $=50902411>$.
\end{abstract}

APPADURAI, Arjun. Disjunção e diferença na economia cultural global. In: FEATHERSTONE, Mike (Org.). Cultura global: nacionalismo, globalização e modernidade. Petrópolis: Vozes, 1994.

87 Daí que alguns autores considerem a notícia como um sintoma social cuja análise de produção fornece pistas do mundo. Segundo Baczko (1984), a informação e os imaginários se estimulam e se contaminam mutuamente. 
BACZKO, Bronislaw. Los imaginarios sociales. Memorias y esperanzas colectivas. Buenos Aires: Nueva Visión, 1984.

BUTLER, Judith. Problemas de gênero: feminismo e subversão da identidade. Rio de Janeiro: Civilização Brasileira, 2003.

CLARÍN, [Buenos Aires, Argentina], 06/10/2004.

DAMMERT, Lucía. Entre el temor difuso y la realidad de la victimización femenina en América Latina. In: FALÚ, Ana; SEGOVIA, Olga (Eds.). Ciudades para convivir: sin violencias hacia las mujeres. Red Mujer y Hábitat de América Latina: UNIFEM: AECID. Santiago de Chile: Ediciones SUR, 2007.

DAS, Veena. Critical Events: An Anthropological Perspective on Contemporary India. New Delhi: Oxford University Press, 1995.

LA VOZ DEL INTERIOR. Argentina: Córdoba. Disponível em: <http://archivo.lavoz. com. br/2004/2012 UM/index.htm>. Em: 12 out.2004.

DICKEY, Sara. La antropología y sus contribuciones al estudio de los medios de comunicación. Revista Internacional de Ciências Sociais, UNESCO, n. 153 p. 1-23, 1997. Disponível em: <www. unesco.org/issj/rics153/dickeyspa.html>.

ECKERT, Cornélia. A cultura do medo e as tensões do viver a cidade: narrativa e trajetória de velhos moradores de Porto Alegre. In: MINAYO, M. C. de S.; COIMBRA Jr. C. (Orgs.). Antropologia, Saúde e Envelhecimento. Rio de Janeiro: Editora Fiocruz, p. 73-102, 2002. (Coleção Antropologia e Saúde). 
. Cultura do medo e cotidiano de idosos porto-alegrenses.

Revista Brasileira de Sociologia da Emoção. João Pessoa, Paraíba, v. 2, n. 4, p. 33-71, 2003.

. A cidade com qualidade. Estudo de memória e esquecimento sobre medo e crise na cidade de Porto Alegre. Sociedade e Cultura, v.10, n.1, dez., p.61-79, 2007. Disponível em: <http://www. revista.ufg.br/index.php/fchf/article/view/282/2123>

ESCOSTEGUY, Ana C. Cartografias dos estudos culturais: uma versão latino-americana. Belo Horizonte: Autêntica, 2001.

FOUCAULT, Michel. Arqueologia do saber. 4. ed. Rio de Janeiro: Forense Universitária, 1995.

. Historia de la sexualidad - La voluntad de saber, v.1. Buenos Aires: Siglo XXI, 1990.

. Em defesa da sociedade: curso no Collège de France (1975-1976). Tradução de Maria Ermantina Galvão. São Paulo: Martins Fontes, 2000.

. Eu, Pierre Rivière, que degolei minha mãe, minha irmã e meu irmão. Rio de Janeiro: Graal, 1991.

. Os anormais. São Paulo: Martins Fontes, 2001.

. Saber y verdad. Madrid: La Piqueta, 1992.

. A ordem do discurso. São Paulo: Edições Loyola, 1996. 
.Vigiar e punir. Petrópolis: Vozes, 2004.

FUNCK, Susana Bornéo; MINELLA, Luzinete Simões (Orgs.).

Saberes e fazeres de gênero: entre o local e o global. Florianópolis: Ed. da UFSC, 2006.

GLESER, Claudio; LEGUIZAMON, Dante. La marca de la bestia. Córdoba: El Emporio Ediciones, 2005.

GROSSI, Miriam. Novas/velhas violências contra a mulher no Brasil. Revista Estudos Feministas, v. 2 (número especial), p. 473-483, 1994.

. Identidade de Gênero e Sexualidade. Revista

Antropologia em Primeira Mão, Florianópolis: UFSC, Programa de Pós-Graduação em Antropologia Social, n. 24, p. 1-18, 1998.

. Gênero, Violência e Sofrimento. Revista Antropologia em

Primeira Mão, 2.ed. (1998ª). Florianópolis: UFSC, Programa de Pós Graduação em Antropologia Social, n.6, p. 1-22, 1995.

HALL, Stuart. A identidade cultural na Pós-Modernidade. Rio de Janeiro: DP\&A, 1997.

. Da diáspora: identidades e mediações culturais. Belo Horizonte: Editora da UFMG, 2003.

HAMBURGER, Esther I.; ALMEIDA, H. B. Sociologia, pesquisa de mercado e sexualidade na mídia: audiências $\mathrm{x}$ imagens. In: PISCITELLI, Adriana; GREGORI, Maria Filomena; CARRARA, 
Sérgio (Orgs.). Sexualidade e Saberes: Convenções e Fronteiras. Rio de Janeiro: Garamond, 2004.

HAMBURGER, Esther I. O Brasil antenado: a sociedade das novelas. Rio de Janeiro: Jorge Zahar Editor, 2005.

HENN, Ronaldo; OLIVEIRA, Carmen S. Criminalidade e notícias nos jornais de Porto Alegre. In: SBPJor, 3, Salvador: UFBA, CD-ROM, 2004.

KOURY, Mauro. A dor como objeto de pesquisa social. Ilha Revista de Antropologia, Florianópolis: UFSC, Programa de Pós-Graduação em Antropologia Social, n. 0, p. 73-83, 1999.

LACLAU, Ernesto. Breves reflexiones sobre la revolución de nuestro tiempo. Buenos Aires: Nueva visión, 1993.

MADRIZ, Esther. A las niñas buenas no les pasa nada malo. México: Siglo XXI, 2001.

MARCUS, Sharon. Cuerpos en lucha, palabras en lucha: una teoría y una política para la prevención de la violación. Revista Debate Feminista. México: Metis Productos Culturales, v. 13, n. 26, 2002.

MAROCCO, Beatriz; BERGER, Christa. A notícia como forma de controle social. Revista Contracampo, Niterói: UFF, v. 14, p. 7-17, 2006.

MARTÍN-BARBERO, Jesús. Secularización, desencanto y reencantamientomassmediático. In: PRE-TEXTOS. Conversaciones sobre las comunicaciones y sus contextos. Cali: Universidad del Valle, 1995. 
. Os métodos dos meios e das mediações. In: Dos meios às mediações: comunicação, cultura e hegemonia. Rio de Janeiro: Editora UFRJ, 2003.

MOTTA, Flávia de Mattos. A morte na janela: a ideia de morte em representações contemporâneas de estupro. In: MINELLA, Luzinete Simões; FUNCK, Susana Bornéo (Orgs.). Saberes e fazeres de gênero: entre o local e o global. Florianópolis: Ed. da UFSC, 2006.

. Raça, gênero, classe e estupro: exclusões e violências nas relações entre nativos e turistas em Florianópolis. PHYSIS: Revista Saúde Coletiva, Rio de Janeiro, v. 16, n. 1, p. 29-44, 2006 a.

PITCH, Tamar. El género de la seguridad urbana. Perugia: Universidad de Perugia, 2008.

REGUILLO, Rossana. Las estrategias del desencanto. Emergencia de culturas juveniles. Buenos Aires: Norma, 2000a.

. La construcción social del miedo. Narrativas y prácticas urbanas. In: ROTCKER, S. (Ed.). Ciudadanías del miedo. Caracas: Nueva Visión, 2000b.

. Los laberintos del miedo, Un recorrido para fin de siglo. Revista de Estudios Sociales, n. 5, Bogotá: Facultad de Ciencias Sociales, Uniandes/Fundación Social, p. 63-72, 2000c.

. Memorias, performatividad y catástrofes: Ciudad interrumpida. Contratexto: Revista de la Facultad de Comunicación de la Universidad de Lima. Lima: Perú, v. 4, mayo 2006. 
. Los miedos contemporáneos: sus laberintos, sus monstruos, sus conjuros. Una lectura socioantropológica. Revista Etnografías contemporáneas. Buenos Aires: Universidad Nacional de San Martín, p. 45-72, 2006a.

. Políticas de la mirada: hacia una antropología de las pasiones contemporáneas. In: DUSSEL, Inés; GUTIÉRREZ, Daniela (Comp.). Educar la mirada. Políticas y pedagogías de la imagen. Buenos Aires: Manantial/FLACSO/OSDE, p.59-74, 2006b.

. La in-visibilidad resguardada: Violencia(s) y gestión de la paralegalidad en la era del colapso. Diálogos transdisciplinarios en la sociedad de la información. La Paz: Fundación REDES, p. 33-44, 2010.

RIAL, Carmen. Guerra de imagens: o 11 de setembro na mídia. Antropologia em Primeira Mão, Florianópolis: UFSC, Programa de Pós Graduação em Antropologia Social, n.64, p.4-21, 2003.

. Estudos de mídia: breve panorama. Antropologia em primeira mão, Florianópolis: UFSC, Programa de Pós Graduação em Antropologia Social, n.74, 2004.

. Guerra de Imagens e Imagens da guerra: estupro e sacrifício na guerra do Iraque. Revista Estudos Feministas, v. 15, p. 14-49, 2007.

RIFIOTIS, Theóphilos. Nos campos da violência: diferença e positividade. Antropologia em primeira mão. Florianópolis: UFSC, Programa de Pós-Graduação em Antropologia Social, n. 19, p. 1-19, 1997. 
SCHMUCLER, Héctor. Triunfo y derrota de la comunicación.

Revista Artefacto, pensamientos sobre la técnica, Buenos Aires, 2008. Disponível em: <www.revista-artefacto.com.ar>.

SCOTT, Joan. Gênero, uma categoria útil de análise histórica. Mulher e realidade: Mulher e educação. Porto Alegre, Vozes, v. 16, n. 2, jul./dez. 1990.

SEGATO, Rita Laura. A Estrutura de Gênero e a Injunção do Estupro. In: BANDEIRA, Lourdes; SUÁREZ, Mireya (Org.). A Violência sexual no Distrito Federal. Brasília: Paralelo 15, 1999.

SOARES, Luiz E. Cultura do medo e violência no Rio de Janeiro. Rio de Janeiro: Ed. Relume Dumará, 1995.

SPITULNIK, Debra. Anthropology and mass media. Annual Review of Anthropology, n. 22, p. 293-315, 1993.

TRAVANCAS, Isabel. A mídia no foco da antropologia. In: REUNIÃO BRASILEIRA DE ANTROPOLOGIA, 26, 2008, Porto Seguro. Bahia, Brasil, 2008. (Trabalho apresentado).

VAN DIJK, Teun A. La noticia como discurso. Barcelona: Paidós Comunicación, 1990 [1980].

. La ciencia del texto. Barcelona: Paidós, 1996.

. Prólogo. In: GIALDINO, Irene V. La construcción de representaciones sociales. Discurso político y prensa escrita. Un análisis sociológico, jurídico y lingüístico. Barcelona: Gedisa, p.15-19, 1998. 
. (Org.). El discurso como interacción social. Barcelona:

Gedisa, 2000.

VERÓN, Eliseo. El análisis del contrato de lectura, un nuevo método para los estudios de posicionamiento delos soportes de los media. In: Les Medias: experiences, recherchesactuelles, aplications. París: IREP, 1985.

. La semiosis social: fragmentos de una teoría de la discursividad. Barcelona: Gedisa, 1987.

. La palabra adversativa, Observaciones sobre la enunciación política. In: Discurso Político, Lenguaje Y Acontecimiento. Buenos Aires: Hachette, p.12-26, 1987a.

. Construir el acontecimiento: los medios y el accidente de ThreeMile Island. Barcelona: Gedisa, 1987b.

. Semiosis de lo ideológico y del poder. La mediatización. Buenos Aires: Universidad de Buenos Aires, Secretaría de Extensión Universitaria, 1995.

. El cuerpo de las imágenes. Buenos Aires: Norma, 2001.

. Fragmentos de un tejido. Barcelona: Gedisa, 2004.

VOGEL, D. Sobre Foucault e o jornalismo. In: ENCONTRO NACIONAL DE PESQUISADORES EM JORNALISMO (SBPJor), 6, São Paulo, 2008. Anais... São Paulo, Unesp, 2008. Disponível em: http://sbpjor.kamotini.kinghost.net/sbpjor/admjor/arquivos/coordenada2daisivogel.pdf. Acesso em: 04/01/2011. 
VOGEL, Daisi. Sobre Foucault e o jornalismo. Verso e reverso, Revista de Comunicação, Unisinos, v. 25, n. 58, p. 45-48, jan./ abr. 2011. Disponível em: <http://www.unisinos.br/revistas/index.php/ versoereverso/article/view/789/145>

ZALUAR, Alba. Medo do crime, medo do diabo. Rio de Janeiro: IMS-UERJ; Campinas: Unicamp,1994. 


\section{Visões de um quase acontecimento: desenvolvimento, sustentabilidade e as disputas de sentido no debate midiático sobre Belo Monte}

Luciana de Oliveira

\section{Introdução}

A tomada de consciência sobre a existência de uma questão ambiental pode ser pensada como um dos grandes acontecimentos constituintes da contemporaneidade. A potência dos acontecimentos se consubstancia na abertura do debate em torno de campos problemáticos. No artigo, analiso os discursos sobre desenvolvimento econômico e sustentabilidade ambiental presentes numa amostra do debate midiático nacional sobre a instalação da Usina Hidrelétrica de Belo Monte na Amazônia brasileira que dão a ver - fazem-fazer e fazem-falar (LATOUR, 2002) - atores e enquadramentos tradutores de modos de entendimento acerca das relações entre natureza-cultura que se colocam em disputas hegemônicas de sentido (LACLAU; MOUFFE, 2004). A disputa pressupõe uma rearticulação hegemônica permanente, devendo ser pensada ao nível das superfícies 
discursivas. Assim sendo, elegi a observação da realidade social no campo da articulação, renunciando à sociedade como totalidade fundante e admitindo radicalmente seu caráter processual.

É preciso salientar que o que se apresenta tanto no caso amplo da questão ambiental, quanto no caso particular da construção de Belo Monte, é um quase acontecimento, na medida em que "a grande catástrofe" no caso da questão ambiental ou os efeitos positivos ou negativos da construção da usina, são, por hora, uma eminência, vivida predominantemente no campo narrativo, porém com alto grau de afetação tanto na vida cotidiana dos cidadãos quanto na mobilização de interesses em torno de uma disputa política repleta de antagonismos e assimetrias.

A pesquisa recorta temporalmente o debate na fase prévia à concessão da Licença de Instalação da Usina que ocorre em junho/2011. Além disso, a experiência de Belo Monte é para a maioria dos cidadãos brasileiros uma experiência vivida pela e com a "mediação da mídia". Ambos os elementos são fundamentais para caracterizar o que estou chamando de quase acontecimento. De maneira mais ampla, gostaria de enfatizar que quase acontecer é um modo de acontecer, valendo investigar esse quase como atributo de alguns acontecimentos. Nesse sentido, a dicotomia realidade $X$ representação perde terreno como base explicativa bem como a dicotomia correlata fato $X$ acontecimento midiático via da qual se enfatiza $o$ acontecimento como a narrativa do fato.

\section{Delineamento da questão: acontecimento, quase acontecimento e Belo Monte}

No contexto da comunicação, olhar para os fenômenos sob a lógica do acontecimento implica admitir que os fatos que ganham visibilidade e mobilizam um debate público podem introduzir algo 
de novo, não estando condicionado aquilo que os provocou. Queré (2005, 2012) e França (2012) têm buscado assinalar a potência do acontecimento em abrir o debate público sobre temas e problemas, muitas vezes, não visíveis e de produzir socialidade a partir das apropriações cotidianas que lhe imputam sentidos e se materializam por meio da sua narrativização, consolidando experiências do viver em comum de variado grau de intensidade.

Há uma dualidade temporal no acontecimento por sua capacidade de alongar-se para o futuro e desdobar-se ao passado. Dessa dualidade, resulta o fato de o acontecimento ser explicável e ao mesmo tempo explicativo. "O acontecimento é um fenômeno de ordem hermenêutica: por um lado, ele pede para ser compreendido, e não apenas explicado, por causas; por outro, ele faz compreender as coisas - tem, portanto, um poder de revelação" (QUERÉ, 2005, p. 60).

Ao entender o acontecimento como algo que irrompe é como se ele representasse o desequilíbrio numa situação de equilíbrio, ou seja, numa ordem dada, daí resultando inclusive sua potência transformadora. É que, ao impor a instabilidade, os acontecimentos requerem a revisão de quadros de sentidos instaurados e abre-se então a possibilidade para outras leituras dos fenômenos que ultrapassam os enquadramentos cristalizados.

Contudo, há uma noção de ordem implícita aí que, a meu ver, deve ser revista para conectar o conceito com algumas preocupações contemporâneas em torno da reificação do conceito de sociedade. A vida social é feita de acontecimentos - entrelaçados às nossas mais corriqueiras visões e experiências do/no mundo vivido - aos quais muitas vezes é difícil atribuir uma ordem. Como nos diz Frederich Barth (1992), em sua crítica radical ao conceito de sociedade, a vida social é caracterizada pela desordem, pelo fluxo 
das interações. A ordem é efeito emergente e não causa imanente. Assim como assinalou Aristóteles em sua Poética,

Nossas impressões sobre a vida humana são colhidas uma a uma e permanecem, para a maioria de nós, frouxas e desorganizadas. Entretanto, encontramos constantemente coisas que subitamente coordenam e trazem a foco uma grande quantidade dessas impressões. (ARISTÓTELES citado por GEERTZ, 1978, p. 318).

A narrativização que ocupa os meios de comunicação - jornalística ou não, especializada ou não - segue a lógica do que Aristóteles chamou de acontecimentos típicos posto que não se propõem a contar só o que aconteceu, mas aquilo que está sempre acontecendo. É, por isso, que a relação entre acontecimento-existencial - aquele que está inscrito no terreno do sensível e da experiência concreta do mundo - e acontecimento-objeto - aquele que é dotado de significação posto que é objeto de escrutínio ou de enquete e, portanto, de interpretação (QUERÉ, 2012) ganha tanta importância, pois é ela que constituirá o ordenamento do real, pela via da narrativização, buscando fazer emergir um mundo dentre tantos possíveis.

A tal perspectiva, que exalta de antemão uma positividade transformadora do acontecimento por sua capacidade de afetação e exigência de narrativização, eu agregaria um vetor de poder, ressaltando também que tal processo engendra disputas de sentido ao colocar em cena vários enquadramentos de uma mesma questão. Assim, para além de prever a produção de uma nova ordem a partir do acontecimento, é preciso, a meu ver, acentuar os antagonismos que estruturalmente perpassam as interações - não como um determinante delas, mas como algo que está em jogo e no jogo não 
somente de uma perspectiva exterior que as atravessa, mas como algo que está dentro dos sujeitos que a compõem - e que estabelecem, a partir do desordenamento inerente à experiência do mundo e dos outros, formas possíveis de lê-lo e, consequentemente, de vivê-lo.

Portanto, ao situar os símbolos no campo social, há modos de interpretação em disputa de sentido. Laclau e Mouffe (2004) descrevem a disputa hegemônica como uma disputa num campo discursivo, mais amplo que os limites da classe - conceito um tanto rígido na teorização marxista clássica e mesmo ainda no pensamento de Gramsci que os inspira.

A disputa pressupõe uma rearticulação hegemônica permanente, devendo ser pensada no mundo contemporâneo ao nível das superfícies discursivas. A hegemonia é uma construção de linguagem na qual suas ambiguidades são admitidas como fator explicativo. Sob a visão desconstrutivista de Derrida, os autores veem o signo tanto como traço daquilo que ele substitui (rastro) quanto como traço daquilo que ele não é (diferença). Decorre disto a ambiguidade discursiva, consistindo a luta hegemônica em tentar consagrar certas interpretações como válidas - o centro que detém o fluxo das diferenças ou pontos nodais - bem como em fornecer uma aparente unidade àquilo que em si mesmo é diverso. Assim sendo, o ponto de observação da realidade social escolhido por eles localiza-se no campo da articulação, devendo renunciar à sociedade como totalidade fundante de seus processos parciais:

Devemos, pois, considerar a abertura do social como constitutiva de uma "essência negativa" do existente e às diversas "ordens sociais" como tentativas precárias e em última instância falidas de domesticar o campo das diferenças. Nesse caso, a 
multiformidade do social não pode ser apreendida por meio de um sistema de mediações, nem pode a "ordem social" ser concebida como um princípio subjacente. Não existe um espaço suturado que possamos conceber como uma "sociedade", já que o social precisaria de essência. (LACLAU; MOUFFE, 2004, p. 132).

O discurso (singular no sentido conceitual, mas sempre plural na realidade empírica) seria a tentativa de dominar o campo da discursividade, de deter o fluxo das diferenças, de construir um centro - um ponto nodal - fornecendo ao real uma aparente unidade. $\mathrm{O}$ ponto nodal é, precisamente, o significado que se torna privilegiado numa articulação discursiva, que consegue se estabelecer como hegemônico, fixando-se em uma cadeia: na medida em que nenhum conteúdo específico está predeterminado a preencher o vazio estrutural, é o conflito entre vários conteúdos tentando desempenhar esse papel de preenchimento que vai tornar visível a contingência da estrutura ${ }^{88}$.

$\mathrm{Na}$ medida em que se refere a objetos somente acessíveis por meio de recursos comunicativos, não poderia deixar de aludir aos princípios constitutivos do "discurso", desde que na compreensão desse elemento haja um esforço em ultrapassar o nível das características, formas e estruturas linguísticas, para entrar no campo

88 As influências teóricas que mobilizam a revisão proposta por Laclau e Mouffe são três (elencadas pelos próprios autores no prólogo à primeira edição em espanhol Hegemonía y estratégia socialista): 1) a crítica ao essencialismo filosófico, consubstanciada na recusa à chamada metafísica da presença (o que inclui a noção de jogos de linguagem de Wittgenstein, a afirmação da faticidade e historicidade do ser no pensamento de Heidegger e a crítica pós-estruturalista à fixidez da relação significante/significado na constituição do signo); 2) o novo papel dado à linguagem na estruturação das relações sociais; 3 ) a desconstrução da categoria de "sujeito" no que diz respeito à construção das identidades coletivas. 
da ideologia. É exatamente a tentativa de consenso, que se dá no contexto da pluralidade e dos conflitos entre os grupos sociais, que constitui a prática articulatória de que falam Laclau e Mouffe, a disputa hegemônica ${ }^{89}$. Prática a partir da qual os significados podem assumir outros sentidos. Mas reconhecer que o sentido e as práticas articulatórias são posicionais e contingentes não elimina o pressuposto como fazem entender os autores - de que essas novas posições não se dão num vácuo, e sim sobre uma teia de outras representações e significados já existentes. Ao conflito e à busca do consenso, portanto, seguem-se a objetivação e a ancoragem (num processo dinâmico e conflitivo) do novo sobre o "estabelecido". Não é a pobreza de significados, mas, ao contrário, a polissemia que desarticula uma estrutura discursiva. Assim, as duas condições para uma articulação hegemônica são: a presença de forças antagônicas e a instabilidade das fronteiras que as separam.

No caso do debate midiático em torno da construção de Belo Monte e mesmo no caso amplo da chamada questão ambiental tais condições são facilmente notáveis. No entanto, também nos dois casos, pode-se dizer que estamos diante de um quase acontecimento, na medida em que "a grande catástrofe" é só uma eminência, mas a sua experiência, no plano narrativo, afeta a vida cotidiana das pessoas e seu modo de estar no mundo, além de mobilizar disputas políticas. Quase acontecer, portanto, não é um não acontecer, é um modo de acontecer, valendo investigar essa quasidade do

89 É nesse sentido que os autores reconhecem a maior contribuição de Gramsci ao avanço teórico e político da esquerda. Ele foi o único pensador da Terceira Internacional capaz de substituir o conceito de representação pelo de articulação, ou seja, a aceitar tanto a diversidade estrutural das relações nas quais os agentes sociais estão imersos, quanto o fato de que o grau de unidade que possa existir entre as mesmas não é expressão de uma essência comum subjacente, mas sim a resultante de uma luta e construção políticas. 
acontecimento (VIVEIROS DE CASTRO, 2011). É algo sobre o que se fala (passível de narrativização), mas que ainda não aconteceu como fato.

O quase acontecimento é o acontecimento cuja existência é estritamente narrativa. A morte é um exemplo de quase acontecimento. Nas sociedades ameríndias, por exemplo, a afetação causada pelo encontro com os espíritos na floresta, que podem distrair e atrair os vivos para o mundo sobrenatural é uma experiência chocante que precisa ser narrativizada. Entretanto, Viveiros de Castro aproxima tal experiência nas sociedades complexas com o encontro com o Estado (ser parado pela polícia, ser perseguido pelo leão do Imposto de Renda), já que o Estado é antítese do parentesco: diante dele somos todos iguais, todos não-pessoas. O Estado é a alteridade absoluta para nós e no encontro com as forças da ordem impessoal por ele imposta ocorre uma "despossessão subjetiva". O que está em disputa, portanto, é a condição de sujeito, pois é ela o que pode definir uma situação ${ }^{90}$.

A questão pública do meio ambiente pode ser pensada como um dos grandes quase acontecimentos contemporâneos e constitui atualmente uma agenda estratégica para as coletividades humanas

90 A definição de situação é um termo importante na economia explicativa do chamado interacionismo simbólico que tem por pano de fundo a filosofia pragmatista e que muito contribuiu para as análises fenomenológicas da vida social. Foi William I. Thomas quem a cunhou para designar tanto as tentativas idiossincráticas do indivíduo de se orientar numa situação atípica quanto sua aceitação da "definição" culturalmente preestabelecida de situações típicas. Segundo o autor, nossas ações são precedidas por um estágio de exame e deliberação no qual se rivalizam a definição individual espontânea da situação e a definição provida pela sociedade. O indivíduo tende para a seleção hedonista - prazer primeiro - e a sociedade para a seleção utilitária - segurança primeiro (THOMAS, 2002). A conexão teórica entre quase acontecimento e definição de situação é um dos eixos estruturadores da pesquisa, no entanto, sua apresentação aqui ultrapassa a questão recortada para este artigo. 
(LOPES, 2004; ZHOURI; LASCHEFSKI; PEREIRA, 2005; DUPAS, 2007). Em âmbito acadêmico, ela desvela fronteiras de estudo que tornam a observação antropológica de nosso próprio mundo algo possível e, indo mais longe, guarda uma potência transformadora da cultura intelectual que sustenta as distinções e especializações do saber.

É cada vez mais pertinente a discussão dos padrões de ação humana sobre a natureza em face de temas como as mudanças climáticas e o aquecimento global, o fim de certos recursos naturais, a intervenção genética como forma de ampliar a produtividade, o desaparecimento de espécies animais e vegetais e a ameaça de destruição de biomas. Se, por um lado, a intensidade com que tais discussões recentemente têm sido mediatizadas confere à questão ambiental particular urgência, por outro, é preciso entender como o tratamento da questão ocorre a fim de ver de que maneira se desenham os interesses dos atores envolvidos e suas possíveis implicações para o debate público, a qualidade da informação, a formação e reconfiguração de imaginários e o grau de abertura da discussão à participação de várias vozes.

A catástrofe final não aconteceu, mas o seu debate, acionado por um conjunto de indícios que vão desde descobertas científicas, fenômenos naturais e modos de organização social e política, instaura um campo problemático - conceito que Queré toma de empréstimo de Deleuze. Um dos aspectos mais relevantes descortinado pelo debate diz respeito às relações natureza-cultura. Beck (1992, p. 80) chamou de sociedade de risco ao atual momento da modernidade reflexiva e avaliou que nele assistiríamos ao "fim da antítese entre a natureza e a sociedade" a partir da "multiplicação de situações de risco", fazendo com que a natureza - o que é dado, atribuído, passível de ser subjugado, alheio, não-sociedade - pudesse ser vista como produto histórico. 
Bruno Latour (1994) oferece-nos um ponto de vista correlato, mas distinto. Na história da cultura, a modernidade é ordinariamente associada à invenção do humanismo, a irrupção das ciências e à secularização das visões de mundo. $\mathrm{O}$ autor identificou um movimento subjacente a este que, na perspectiva de sua longa duração, teve papel instituidor disto que caracteriza o moderno no Ocidente: o trabalho de depuração que resulta na distinção crítica entre humano e não-humano, entre natural e social.

Ao caracterizar o que chamou de "crise", o autor mostra como as pautas dos jornais diários misturam política, discurso e ciência numa operação em que natureza e cultura, não obstante as tentativas de separá-los em ordens de fatos diferentes, relacionam-se de maneira impura. Latour afirma que:

\begin{abstract}
se os fatos não ocuparem o lugar ao mesmo tempo marginal e sagrado que nossas adorações reservam para eles, imediatamente são reduzidos a meras contingências locais e míseras negociatas. Contudo, não estamos falando do contexto social e dos interesses do poder, mas sim de seu envolvimento nos coletivos e nos objetos (LATOUR, 1994, p. 10).
\end{abstract}

Reivindicando então que as redes são o real, ou seja, o entrelaçamento entre a natureza ou fato, o discurso ou narração dos fatos e as coletividades e seus jogos de poder, só não as enxergamos em sua tessitura inteiriça de natureza-cultura porque somos modernos e separamos, distinguimos, depuramos e especializamos o entendimento do real.

A modernidade produziu fenômenos e, ao mesmo tempo, um discurso (científico) para justificá-los que parecem hoje incompatíveis com a proliferação dos híbridos, ou seja, de quase-objetos e 
quase-sujeitos que localizam-se antes da divisão natureza-cultura, sendo em parte natureza e em parte cultura. Contra o modelo instável do relativismo cultural, o autor propõe a ideia de um multinaturalismo que traz uma consequência duplamente significativa: “(a) a natureza não é natural, mas feita; (b) a cultura não é cultural, mas... real. Tão real quanto a natureza, qualquer que seja o nível em que nos situemos" (LIMA, 1999, p. 44).

É possível então falar simetricamente de nós como dos outros sem acreditar nem na razão nem na crença, respeitando, ao mesmo tempo, os fetiches e os fatos (LATOUR, 2002). No entanto, o pensador crítico, o político, o governante, o empresário normalmente não conseguem realizar tal operação. Para eles, está na lista

de objetos-encantados tudo aquilo em que eles não acreditam mais - a religião, é claro, mas também a cultura popular, a moda, as superstições, a ideologia, etc. - e, na lista dos objetos-causa, tudo aquilo em que acreditam convictamente - a economia, a sociologia, a linguística, a genética, a geografia, as neurociências, a mecânica, etc. Reciprocamente, eles vão compor seu polo sujeito, inscrevendo no crédito todos os aspectos do sujeito pelos quais têm consideração - responsabilidade, liberdade, inventividade, intencionalidade, etc. - e no débito, tudo o que lhes parece inútil ou maleável - os estados mentais, as emoções, os comportamentos, as fantasias, etc. (LATOUR, 2002, p. 35). [grifos do autor].

Frente a tais delineamentos, surge a grande questão em relação ao objeto de estudo em foco no presente artigo: como a relação social-ambiental tem constituído a definição de situação no quase acontecimento de Belo Monte? 


\section{As visões de desenvolvimento e sustentabilidade em disputa: Brevíssima caracterização do quase acontecimento Belo Monte ${ }^{91}$}

Historicamente, o marco da construção do complexo de usinas no Rio Xingu remonta a meados dos anos 1970 e os primeiros estudos de viabilidade de barramentos na região amazônica. Naquela época, levar o desenvolvimento à Amazônia, uma "região esquecida", significava aprofundar o modelo econômico de substituição de importações, gerando grandes investimentos em insumos básicos e absorver a maior parte dos recursos externos captados para esse fim. Na década de 1980, a Eletronorte (Centrais Elétricas do Norte S/A) propôs a construção do Complexo Hidrelétrico de Altamira com a construção de três centrais e uma capacidade total de geração de energia de aproximadamente 11 megawatts por mês, o que, considerando-se as oscilações entre cheias e secas, resultaria numa média de 4 megawatts/mês.

Desde então, os diversos governos tentaram iniciar as obras, mas enfrentaram uma batalha técnica, jurídica, política e socioambiental que colocava, sob suspeita, a viabilidade do projeto, principalmente no que diz respeito à sustentabilidade socioambiental. A partir de 2000, a atuação da sociedade civil por meio de ONGs, movimentos sociais, lideranças indígenas e populares, grupos ligados à igreja, cientistas, especialistas na questão ambiental e o Ministério Público Federal do Pará (MPF/PA) intensificaram sua atuação contrária à construção da Hidrelétrica de Belo Monte, tendo como principais argumentos a defesa dos direitos das populações afetadas pelo empreendimento.

91 Síntese feita com base em Pont Vidal (2005), sites e documentos consultados identificados nas referências. 
Como contraponto, principalmente a partir de 2007, com o lançamento do Programa de Aceleração do Crescimento (PAC), a ação governamental para a instalação da hidrelétrica também se instaura de forma mais decisiva e incisiva, norteada pelo que Zhouri (2011, p. 14) vem chamando de paradigma da adequação ambiental.

Neste, a obra assume lugar central, apresentandose de forma inexorável. $\mathrm{O}$ ambiente é percebido como externalidade, ou seja, enquanto paisagem que deve ser modificada e adaptada aos objetivos do projeto técnico. Nesse processo, arranjos e ajustes tecnológicos dados por medidas mitigadoras e compensatórias cumprem a função de adequação. (ZHOURI, 2011, p. 14).

Com base nessa visão, instaurou-se um verdadeiro front de combate em torno do licenciamento ambiental que na visão de Zhouri (2011, p. 14) é "um campo de conflitos em torno da apropriação social da natureza”. Em 2009, a Fundação Nacional do Índio autoriza a construção de Belo Monte, antes mesmo da finalização e dos resultados conclusivos do Estudo de Impacto Ambiental (EIA) e seu respectivo Relatório de Impacto Ambiental (RIMA).

Foi ainda, em 2009, que teve lugar um debate sobre Belo Monte em Washington, o II Encontro dos Povos da Volta Grande do Rio Xingu e a realização de audiências públicas para discutir o Plano de Desenvolvimento Regional Sustentável, no qual se inscreve a construção de Belo Monte (consideradas insuficientes pelo $\mathrm{MPF} / \mathrm{PA}$, por organizações da sociedade civil e lideranças indígenas e comunitárias).

Apesar das manifestações públicas e dos dados sobre a inviabilidade do empreendimento, em dezembro de 2010, o IBAMA 
(Instituto Brasileiro de Meio Ambiente e dos Recursos Naturais Renováveis) concede a Licença Prévia (LP) da obra, o que significa dizer a aprovação da localização e concepção do empreendimento. Em janeiro de 2011, foi concedida a Licença de Instalação (LI) para instalações provisórias, aquelas que dão suporte à obra propriamente dita, e em junho de 2011, a LI para a construção da Usina. Segundo a visão do MPF/PA e das organizações da sociedade civil, o governo brasileiro autorizou o início das obras sem que 66 condicionantes das apontadas no EIA estivessem resolvidas (40 de caráter ambiental e 26 indígenas), incluindo a consulta às comunidades concernidas pela obra.

\section{Nota metodológica}

O objeto empírico sobre o qual me debrucei consistiu na análise das diferentes modalidades da relação natureza-cultura construídas no debate em torno de Belo Monte em quatro veículos diferentes: a Revista Veja (1989-2011) ${ }^{92}$, Jornal Nacional da Rede Globo de Televisão (uma série especial de reportagem 2011 exibida em 23/08/2011, 25/08/2011 e 26/08/2011) ${ }^{93}$, do site

92 A pesquisa foi realizada no arquivo digital da revista VEJA, no qual foram recuperados um total de 30 registros, assim distribuídos por ano: 1 (1989); 4 (2007); 3 (2008); 1 (2009); 12 (2010); 9 (até 08/06/2011).

93 Na pesquisa feita no site: www.globo.com foram recuperados 27 registros do tema "Belo Monte" entre 21/05/2008 e 16/12/2011). Destes, 5 só trazem citações a Belo Monte. São, portanto, 22 reportagens sobre a construção da Usina no total: 3 (2008); 7 (2010); 12 (2011). As reportagens de 2008 são sobre o "ataque" ao engenheiro da Eletronorte; as de 2010 enfocam a licitação da obra; só em 2011 é que os da controvérsia ganham espaço. 
Movimento Xingu Vivo Para Sempre (www.xinguvivo.org.br) ${ }^{94}$, do qual foram analisadas 7 cartas coassinadas pelas organizações membro e do blog Belo Monte de Violências (http://belomontedeviolencias.blogspot.com $)^{95}$. O recorte temporal compreende, no caso de Veja, um período mais extenso, buscando ver em quais momentos o debate ganhou maior visibilidade e com quais conteúdos. Os demais lócus de observação ganharam um tratamento mais sincrônico, considerando especialmente os anos mais recentes, quando o debate público de Belo Monte ganha abrangência massiva na imprensa brasileira. Veja e Jornal Nacional representam a chamada "grande mídia", pois são, respectivamente, a revista e o jornal televisivo de maior penetração no Brasil. O site e o blog escolhidos representam vozes de protesto e resistência contra a construção de Belo Monte de notável visibilidade pública ${ }^{96}$.

$\mathrm{O}$ material foi primeiramente mapeado e sistematizado na forma de um banco de dados de dupla entrada. Nas colunas, foram organizadas as categorias a serem observadas nos materiais, sendo

94 O Movimento Xingu Vivo é uma organização que congrega diversas organizações sociais de diferentes origens que atuam na Amazônia ou ligadas a causas ambientais em nível nacional e internacional. Sua articulação aconteceu após o Encontro Xingu Vivo Para Sempre em 2008. Para captar a visão dos movimentos que o integram, optei por priorizar as cartas divulgadas no site (um conjunto de 7 textos) e em outros meios de comunicação, normalmente coassinadas por várias das organizações-membro no período de maio/2008 a junho/2011.

95 O blog pertence ao procurador do Ministério Público Federal do Pará, Felício Pontes Jr, e foram observadas especialmente as colunas: Histórico (que congrega uma série de 10 artigos publicados na imprensa paraense com um histórico do caso a partir do ano 2000) e Artigos (que congrega 4 artigos publicados em diversos meios).

96 Fazem parte do escopo da pesquisa, além destes, a Folha de São Paulo (jornal impresso de maior circulação nacional), o Movimento dos Atingidos por Barragens - MAB (www.mabnacional.org.br), além de um conjunto de vídeos e de falas/perfis em redes sociais. 
elas: Desenvolvimento; Sustentabilidade; Progresso. Busquei ainda observar como se constituem as visões do Outro, ou seja, as visões recíprocas das forças antagônicas e como são apresentadas as relações Natureza-Cultura ou Natureza-Sociedade. Nas linhas, foram anotados os dados da fonte, tais como: autor da fala; lugar de fala; veículo. Buscando compreender o papel de vários grupos sociais em disputa - especialmente lideranças políticas, técnicas, empresariais, intelectuais, locais, comunitárias, indígenas - o objetivo é lançar luz sobre o papel articulador de certas formas de pensar, de ver e de experimentar o quase acontecimento. Portanto, não obstante o material empírico trabalhado seja composto por textos, o que importa deles reter é que são, antes de mais nada, "práticas de sentido" (VIVEIROS DE CASTRO, 2002) fundamentais para a análise como "sociograma vernacular" (MARTINS, 2008) que documenta as relações e as posições sociais numa descrição verbal de proximidades e distâncias presentes nas interações.

\section{Lugares da natureza-cultura}

A visão dos movimentos sociais e do Ministério Público Federal do Pará (MPF-PA) que atuaram e ainda atuam contra a construção da usina de Belo Monte pode ser exemplarmente notada no site do Movimento Xingu Vivo e no blog Belo Monte de Violências. As informações neles veiculadas, além de reveladoras de suas posições, reverberaram nas redes sociais e também na "grande mídia".

A atuação do MPF-PA no caso começa no ano de 2000 observando ilegalidades na condução do processo de licenciamento. No conjunto, foram 12 ações civis públicas impetradas contra o governo. Tal nível de ativismo por parte do MPF-PA não ocorre no vácuo e nem é fruto de um acaso. Num de seus textos, relatando o histórico do caso, destaca Pontes Jr.: 
Altamira possui o movimento social mais atuante da Amazônia. Os colonos que chegaram com a abertura da Transamazônica, e conseguiram sobreviver à propaganda enganosa da ditadura militar, se juntaram aos povos tradicionais, indígenas e ribeirinhos, somando forças contra principalmente fazendeiros e madeireiros, normalmente financiados pela Sudam e pelo Banco da Amazônia. Esse confronto fez a região produzir vários líderes importantes como Ademir Federicci (o Dema), Bartolomeu Silva (o Brasília), e Irmã Dorothy. Todos foram mortos no embate contra um modelo insustentável de desenvolvimento. Conheci todos eles. (...). [(Procurador da República, Dr. Felício Pontes Júnior, 2000)].

Mesmo considerando tal nível de engajamento das lideranças locais somadas ao esforço do Painel de Especialistas que analisou os resultados do EIA, tudo foi desprezado pelo governo e empresas, especialmente as questões indígenas e as contribuições das audiências públicas. Segundo Felício Pontes Jr, "o governo simplesmente não deu a mínima para questões que colocavam em xeque a viabilidade do projeto. O objetivo era obter a Licença Prévia, e só”. O mesmo modelo de desenvolvimento se repete no Pará:

A floresta vira carvão para alimentar os fornos das guseiras. Ou soja para alimentar os porcos da Europa. Ou pasto para formar a ineficiente equação de um boi/hectare. Ou é inundada para produzir energia para empresas de outros países... (Felício Pontes Jr., artigo publicado pelo Diário do Pará em 07.09.11). 
O verdadeiro potencial da região é o desenvolvimento local, integrado com a Floresta:

Tudo isso acontece justo agora que a região vem investindo em seu verdadeiro desenvolvimento econômico; justo agora que os projetos de reflorestamento começam a dar resultado; justo agora que ela se tornou a maior produtora de cacau do Brasil; justo agora em que uma fábrica de chocolate e pequenas usinas de beneficiamento de frutas e óleos vegetais se instalaram. (Procurador da República, Felício Pontes Jr., 2011).

Nos textos do Movimento Xingu Vivo, há dois eixos de ação importantes: o primeiro é desfazer a visão de que os direitos dos índios são contrários ao desenvolvimento. Nesse sentido, o desenvolvimento de um país não se mede apenas por seu crescimento econômico, mas também pela maturidade de suas instituições e capacidade destas em representar a nação,

Um país no qual um de seus principais tribunais fecha os olhos para as muitas irregularidades de um processo sob o pretexto de que isso é necessário para o desenvolvimento, tem um futuro sombrio. Como pode haver desenvolvimento sem respeitar as regras mínimas estabelecidas? (Nota do MOVIMENTO XINGU VIVO PARA SEMPRE acerca do leilão da UHE de Belo Monte).

O outro eixo de ação é propor um outro modo de desenvolvimento econômico. Os dizeres de um cartaz empunhado por ribeirinhos em manifestação contra Belo Monte resume tal 
posição: “Desenvolvimento sim! De qualquer jeito não!” (ênfases mantidas):

Um outro desenvolvimento [é] possível na Amazônia do século 21, partindo dos anseios das populações locais e pautado em princípios de justiça social, sustentabilidade ambiental e inovação econômica, com valorização da biodiversidade e dos serviços ambientais. Assim, experiências inovadoras como o Plano BR-163 Sustentável, construídas com forte protagonismo da sociedade civil, são abandonadas em favor do desenvolvimentismo convencional das mega-obras do PAC. (Carta à Presidente Dilma, 08/02/2011).

Na visão das entidades e grupos sociais que compõem o movimento, os investimentos necessários para um desenvolvimento social e ambientalmente sustentável para a região localizada na área prevista para a construção da Usina são: a consolidação do projeto de agricultura familiar por meio do ordenamento fundiário e ambiental, da infraestrutura para os assentamentos, da recomposição do passivo ambiental, da melhoria da qualidade de vida dos moradores das áreas rurais e urbanas, assim como a implementação das Reservas Extrativistas. As palavras social e ambiental são inseparáveis nos discursos do movimento.

Já nas reportagens de Veja, é possível perceber vários movimentos e posicionamentos distintos ao longo do tempo, porém, há uma linha condutora que preside a leitura: a desqualificação da participação social dos indígenas no caso. A separação natureza-cultura, essa distinção artificial que os modernos operam, faz situar o índio no polo natureza e, portanto, como entes naturais, eles não são portadores de direitos e seu destino está à mercê dos brancos. Assim, quando os índios se organizam para lutar por seus direitos, há duas grandes chaves de leitura: a selvageria e a cooptação. 
O cenário é maniqueísta. $\mathrm{O}$ mal são os ambientalistas engenheiros florestais brasileiros e "lobbystas" norte-americanos que negociam investimentos na Amazônia - e os índios por eles cooptados (pelo Conselho Indigenista Missionário - CIMI e pela Comissão Pastoral da Terra) que se uniram num ritual a la woodstock, "a taba dos ecologistas", onde "sentaram para fumar o cachimbo da paz e bradar contra a construção da hidrelétrica” (O GRITO..., 1989, p. 46-49). O bem é o pessoal da Eletronorte, principalmente seu corpo diretivo, vítimas dos ataques dos selvagens.

O primeiro episódio foi o da índia Tuíra que "atacou" com um facão no rosto de José Antônio Muniz Lopes porque este defendeu "entusiasmado" o projeto da hidrelétrica Kararaô. Segundo a revista, a índia "gritava incompreensíveis frases em caiapó": "não queremos o progresso". Quase 20 anos depois, ao reportar confrontos entre indígenas e Eletrobrás, notam-se os mesmos enquadramentos. Desde a primeira frase da matéria: "As cenas de um grupo de selvagens amazônicos atacando o engenheiro Paulo Fernando Rezende da Eletrobrás, rodaram o mundo da semana passada” (SOARES, 2008, p. 64). Desta vez, os índios foram incitados pelos ambientalistas ("brancos selvagens" segundo a revista) com a intenção de impressionar jornalistas estrangeiros.

Segundo a revista, um vídeo circulou na internet por obra de ONGs com a cena de Tuíra; outro vídeo flagrou integrantes das entidades que organizaram o evento, dentre eles um padre comprando facões acompanhado de um índio. Àquela altura, a atuação do MPF-PA em relação ao direito dos indígenas serem ouvidos e informados é lida como um empecilho ao início dos estudos, um ato de vontade e obscurantismo para que não se estudem os impactos. Mas, os argumentos agora se complexificam e apresentam contradições entre a visão privatista e as pressões democráticas já que a 
ordem liberal é facilmente absorvida do ponto de vista econômico, mas traz em seu bojo a defesa das liberdades no campo dos direitos.

Assim, nos informa a Revista, "como a obra é considerada estratégica pelo governo, os estudos são imprescindíveis. Ainda mais porque a construção de barragens é considerada por especialistas de todo o mundo a mais prejudicial entre as intervenções humanas na natureza (...). A redução do lago que será formado já foi reduzida de 18.000 quilômetros quadrados para os atuais 440 . Note-se que foram as pressões dos índios e ambientalistas que produziram esse e outros avanços. Tudo isso só demonstra a importância do debate" (SOARES, 2008, p. 65, ênfase minha).

Os polos natureza e cultura são tão separados que, quando indígenas adotam hábitos modernos, isso parece antinatural, "traumático", nas análises da Revista:

Mais complicado que defender o verde contra uma usina, porém, é a defesa da própria civilização indígena. A uma década do século XXI, o ingresso dos nativos no dia-a-dia do mundo moderno tem sido, e será traumático. (...) O índio quer preservar o verde, quer manter a posse de sua terra que são direitos legítimos. O homem branco também quer preservar o verde, e somente um maluco pensaria em colocar fim aos índios dizimando-os. Mas o progresso tecnológico é inevitável. Vai além da ecologia a passagem do índio para esta época de aviões e radiogravadores. (SOARES, 2008, p.49).

As visões de desenvolvimento propagadas na Revista também enfatizam a separação entre natureza-cultura, na medida em que o crescimento econômico aparece como algo oposto aos direitos indígenas. A leitura de Delfim Neto, em entrevista das páginas amarelas na qual cita o caso de Belo Monte, é emblemática dessa visão: 
O setor privado precisa de duas garantias para investir: a de que haverá crescimento e a de que não faltará energia. Se houver essas duas garantias os investimentos virão. Veja o caso do complexo hidrelétrico Belo Monte, no Rio Xingu. Por mais nobre que seja a questão indígena, é absurdo exigir dos investidores que reduzam pela metade a potência de energia prevista num projeto gigantesco porque doze índios cocorocós moram na região e um jesuíta quer publicar a gramática cocorocó em alemão (ENTREVISTA...1993, p. 14).

A partir de 2007, quando o tema ganha maior espaço na Revista, os argumentos apresentados, favoráveis à construção da usina, tornam-se mais sofisticados. A oposição central é desenvolvimento (pensado como crescimento econômico) versus preocupação ambiental. Um dos principais argumentos é o consumo de energia no Brasil que cresce à razão de 5,5\% ao ano e gerar mais energia (SOARES, 2008, p. 64). A tecnologia é a grande bandeira para salvação da natureza. Há um tom de alerta em relação aos perigos das hidrelétricas na Amazônia por "seu ecossistema delicado" (palavras de David Levojoy, acusado de negociador dos interesses norte-americanos na reportagem de 1989). Mas, a moral da história é que tudo será diferente porque a tecnologia construtiva a ser empregada em Santo Antônio, Jirau e Belo Monte é avançada e minimizará todos os possíveis danos ambientais que as usinas e os seus lagos poderão causar.

O mesmo fundamento - necessidades energéticas do Brasil versus direitos das populações atingidas especialmente dos indígenas e ribeirinhos - pode ser percebido na série de reportagens sobre Belo Monte no Jornal Nacional (JN) (23/08/2011; 25/08/2011 e 26/08/2011), [programa noticiário exibido na Rede Globo]. A vazão reduzida da água na Volta Grande do Xingu é apresentada 
como o grande problema na visão dos índios. Mas segundo a razão técnica, este problema também está resolvido. A vazão da água no Rio Xingu, denominada de "vazão ecológica," é uma condicionante que será respeitada com a diminuição do desvio do rio para alimentar o reservatório ou até mesmo a paralisação da Usina na época de seca. Entretanto, as reivindicações são um pouco mais extensas e complexas do que isso. Segundo o Movimento Xingu Vivo, a subestimação de impactos sociais e ambientais ocorre por falhas crônicas na:

a) adoção de conceitos de "atingidos" que desconsideram as relações específicas de populações tradicionais com as florestas, várzeas, igapós e rios da Amazônia (...)

b) sub-dimensionamento de problemas associados à chegada de milhares de migrantes na busca de empregos nos canteiros de obras (...)

c) redução artificial das áreas geográficas impactadas pelas hidrelétricas nos estudos de impacto ambiental (EIA) (...)

d) sub-estimação e negação de impactos sociais e ambientais, e riscos associados (...)

e) falta de abordagem nos EIAs de impactos cumulativos com outros empreendimentos (...)

f) mudanças nos projetos de engenharia e localização de projetos (...) (Carta à Presidente Dilma, 08/02/2011 - ênfases retiradas)

Voltando à reportagem e seu jogo informacional que imita a técnica cinematográfica do campo e contra campo, vê-se por um lado, o argumento de que "sem água não há comunidade" (índio não identificado) se opondo ao de que "o nosso país está crescendo e necessita de aproximadamente cerca de 7.000 megawatts por ano 
nos próximos 10 anos para permitir esse crescimento econômico e o desenvolvimento do nosso país" (Altino Ventura, secretário de planejamento Ministério de Minas e Energia). Como os índios lutaram por seus direitos: "com facões" - os enfrentamentos entre indígenas e corpo diretivo da Eletronorte de 1989 e 2008 voltam à cena.

Outro elemento acionado na narrativização da grande mídia sobre os índios e direitos indígenas é uma imagem de inocência fingida como se atuassem o papel de "bons selvagens". O líder indígena caiapó Cacique Ireô entra em cena: "Quem sabe não vai acontecer a guerra. Branco morre. Índio morre. Até o final eu quero ver acontecer esse barramento" (JORNAL NACIONAL, 26/08/2011). Nota-se também essa imagem em pequenos comentários como o que sucede uma frase do cacique Raoni na seção Radar de Veja: "o presidente Lula me disse que não ia assinar a construção de Belo Monte. Fico preocupado: será que ele falou a verdade pra mim? Do Cacique Raoni que não conhece os desvãos da política”. A visão sobre a participação dos estrangeiros, especialmente de celebridades, no debate - Sting, Signey Weaver, James Cameron e Arnold Schwarznegger - também reforça essa imagem, na medida em que os índios parecem fazer parte de um cenário de exotismo que "seduz" maliciosamente o olhar estrangeiro ${ }^{97}$.

97 Após leilão de licitação, ocorrido em 20/04/2010 com a vitória do consórcio capitaneado pela estatal Companhia Hidrelétrica do São Francisco (CHESF) e não pelas grandes empreiteiras tradicionalmente envolvidas na execução de megaprojetos de infraestrutura, a revista passa a questionar a lisura das empresas ganhadoras, a viabilidade de Belo Monte e desfere duras críticas ao governo. A entrada da Vale no Consórcio parece não ter sido suficiente, num primeiro momento, para mudar a nova trajetória de críticas à obra na revista Veja. Com efeito, no ano de 2011, a Revista reassume uma postura pró Belo Monte. Um dos sinais mais evidentes foi a crítica a um vídeo com celebridades globais que se posicionaram contra a construção da Usina, capa da edição de 12/07/2011. 
Na tabela 1, abaixo, apresento uma síntese dos argumentos presentes em cada veículo ou fonte de pesquisa analisada:

Tabela 1 - Síntese dos argumentos veiculada na mídia

\begin{tabular}{|c|c|}
\hline Blog Belo Monte de Violências & Movimento Xingu Vivo Para Sempre \\
\hline $\begin{array}{l}\text { - Efervescência política de Altamira } \\
\text { vem de uma tradição de líderes locais } \\
\text { contra modelo de desenvolvimento do } \\
\text { Estado e do mercado } \\
\text { - Defesa de modelo de desenvolvimen- } \\
\text { to local, explorando potencialidades da } \\
\text { região. }\end{array}$ & $\begin{array}{l}\text { - Direitos indígenas não são obstáculo } \\
\text { ao desenvolvimento: pensar uma nação } \\
\text { diversa e conseguir reconhecer os direi- } \\
\text { tos de todos é que significa desenvolvi- } \\
\text { mento } \\
\text { - Defesa de um modelo de desenvolvi- } \\
\text { mento calcado na agricultura familiar e } \\
\text { ordenamentos jurídicos, ambientais e } \\
\text { sociais que o preservem. }\end{array}$ \\
\hline Revista Veja & Jornal Nacional \\
\hline $\begin{array}{l}\text { - Desqualificação da participação social } \\
\text { dos indígenas em } 3 \text { chaves: cooptação, } \\
\text { selvageria e inocência fingida (nas três, } \\
\text { o índio está localizado no polo nature- } \\
\text { za) } \\
\text { - Cenário de mocinhos e bandidos: } \\
\text { crescimento econômico x direitos in- } \\
\text { dígenas } \\
\text { - Tecnologia como grande bandeira sal- } \\
\text { vacionista } \\
\text { - Tensões ao longo do tempo, especial- } \\
\text { mente entre uma lógica liberal (faci- } \\
\text { lidade de acolhê-la do ponto de vista } \\
\text { econômico, mas não do ponto de vista } \\
\text { dos direitos) e participação do Estado } \\
\text { no empreendimento em lugar das gran- } \\
\text { des empreiteiras privadas. }\end{array}$ & $\begin{array}{l}\text { - Necessidades energéticas do país x di- } \\
\text { reitos indígenas } \\
\text { - Os grandes problemas que envolvem a } \\
\text { construção da Usina são apresentados: } \\
\text { vazão da água, migração em massa e } \\
\text { seus efeitos e são também RESOLVI- } \\
\text { DOS nas reportagens. } \\
\text { - Tecnologia como solução dos proble- } \\
\text { mas }\end{array}$ \\
\hline
\end{tabular}

Fonte- Elaborada pela autora (2012). 
Já a tabela 2, sintetiza as visões em articulação e disputa hegemônica de sentido no caso da controvérsia em torno da construção de Belo Monte.

Tabela 2 - Visões antagônicas em articulação e seus enquadramentos midiáticos sobre Belo Monte (continua)

\begin{tabular}{|c|c|c|}
\hline \begin{tabular}{|l|} 
Visões \\
Categoria
\end{tabular} & Pró Belo Monte & Contra a Belo Monte \\
\hline Sustentabilidade & $\begin{array}{l}\text { - Governo e Norte Energia não } \\
\text { vão gerar danos sociais nem am- } \\
\text { bientais; } \\
\text { - Crença nas soluções tecnológi- } \\
\text { cas para os problemas (minimiza- } \\
\text { ção e mitigação dos impactos) } \\
\text { - É preciso sustentar os atuais ní- } \\
\text { veis de consumo e de crescimento }\end{array}$ & $\begin{array}{l}\text { - A observação dos modos de vida } \\
\text { das populações locais pode auxi- } \\
\text { liar na criação de modos sustentá- } \\
\text { veis de convivência humanidade- } \\
\text { natureza. } \\
\text { - Hábitos de consumo podem/ } \\
\text { devem ser modificados } \\
\text { - Matriz energética pode ser di- } \\
\text { versificada }\end{array}$ \\
\hline Desenvolvimento & $\begin{array}{l}\text { - Direitos dos índios são contrá- } \\
\text { rios ao progresso. } \\
\text { - Todos os esforços governamen- } \\
\text { tais são para satisfazer necessida- } \\
\text { des energéticas do país e sustentar } \\
\text { taxas de crescimento. }\end{array}$ & $\begin{array}{l}\text { - Observação dos direitos de } \\
\text { todos é sinônimo de nação ple- } \\
\text { namente desenvolvida. O desen- } \\
\text { volvimento não se mede só pelo } \\
\text { crescimento econômico } \\
\text { - Caráter local, observando-se } \\
\text { potencialidade e vocações das } \\
\text { comunidades no relacionamento } \\
\text { com a Floresta e sua biodiversi- } \\
\text { dade. }\end{array}$ \\
\hline Progresso & $\begin{array}{l}\text { - Sinônimo de crescimento eco- } \\
\text { nômico, similar ao otimismo ilu- } \\
\text { minista. }\end{array}$ & - \\
\hline
\end{tabular}

Fonte- Elaborada pela autora (2012). 


\section{Considerações finais}

O debate na grande mídia vem privilegiando os interesses hegemônicos - governamental e mercadológico - de forma mais grosseira quando denomina os defensores da causa dos atingidos pela obra e da preservação ambiental como "ecochatos" (no caso de Veja, essa ênfase é mais explícita e o tom geral é o de caracterizar o movimento como um conluio woodstockiano entre indígenas e ambientalistas) e/ou dar um tom espetacular ao debate como se se tratasse de emoções que dividem as opiniões numa espécie de maniqueísmo simplista.

Mas há também uma maneira mais sofisticada de privilegiar aqueles interesses equacionando o dilema da seguinte forma: de um lado, as necessidades energéticas do país para o crescimento econômico e manutenção dos hábitos de consumo de um amplo espectro da população e, de outro, as necessidades de preservação ambiental à biodiversidade e proteção social e cultural ancorada no campo dos direitos, especialmente os direitos indígenas.

A equação é simples: fazer ou não hidrelétricas é escolher entre crescer ou não crescer. Logo, nessa abordagem, o contrário de crescer é não crescer. Por outro lado, para movimentos ambientalistas e lideranças comunitárias (indígenas e ribeirinhos), em seu modo de ver e dar publicidade à controvérsia, a questão é: há mais de um modo de crescer. Não menos polêmico, mas de certo modo mais obscurecido no debate é o modo como o projeto foi conduzido e o grau de participação e dissenso por ele aberto. Afinal, a destruição de sociedades indígenas em nome de alçá-las ao patamar de progresso da civilização ocidental tem deixado historicamente um rastro de subcidadania.

As visões do outro, tomando como referência, por um lado, a visão dos movimentos de resistência a Belo Monte e, por outro, 
o Estado e os interesses de mercado, são respectivamente: para os movimentos anti-Belo Monte, o Estado é violento, opressor, máquina (rolo compressor) de encobrimento das diferenças, autoritário, não representa arena de disputas de interesses na medida em que há a primazia do interesse econômico sobre o campo dos direitos indígenas.

Já na visão dos poderes hegemônicos, cujos discursos têm encontrado bastante espaço na grande mídia, os índios são ora selvagens ora sujeitos cooptáveis, massa de manobra de ambientalistas e missionários; ora inocentes, ora forças demoníacas; mas sempre parcela insignificante da população sem poder político - não reconhecível nem como agente das modificações no projeto nem como parte importante da Nação.

Entendendo o debate midiático da questão ambiental no quadro da discussão sobre o acontecimento (e quase acontecimento) e seu papel na reinvenção de modalidades de ação habituais e forças estruturais cristalizadas, busco refletir sobre a viabilidade da seguinte hipótese de trabalho: a separação dicotômica do par natureza-cultura subsidia e confere força ao discurso estatal/mercadológico no debate, assim como, por outro lado, a visão que pressupõe a ontologia da relação natureza-cultura (LATOUR, 1994; 2002; VIVEIROS DE CASTRO, 2002; 2011) estruturante dos discursos alternativos, minoritários e indígenas encontra obstáculos de tradução e reverberação na grande mídia, circunscrevendo-se a uma comunicação mais dirigida.

\section{Referências}

BARTH, F. Towards greater naturalism is conceptualizing societies. In.: KUPER, Adam. Conceptualizing Society. London: Routledge, 1992. 
BECK, U. Risk Society: towards a new modernity. London: Sage Publications, 1992.

DUPAS, Gilberto. A questão ambiental e o futuro da humanidade. Política Externa. São Paulo, v.16, n.1, jun/jul/ago, 2007.

ENTREVISTA com Delfim Netto. Veja, edição 1993, 31 jan. 2007. Disponível em: < http://veja.abril.com.br/310107/entrevista.html>.

FRANCA, V. O acontecimento para além do acontecimento: uma ferramenta heurística. In: FRANÇA, V.; OLIVEIRA, L. (org.). Acontecimento: reverberações. Belo Horizonte: Autêntica, 2012.

GEERTZ, C. Uma descrição densa: por uma teoria interpretativa da cultura. In: A interpretação das culturas. Rio de Janeiro: Zahar Editores, 1978.

O GRITO dos caiapós. Veja. Ed. 1065-1068, São Paulo, p.46- 49, fev. 1989.

LACLAU, E.; MOUFFE, C. Hegemonía y estratégia socialista: hacia uma radicalización de la democracia. 2.ed. en español. Buenos Aires: Fondo de Cultura Económica, 2004.

LATOUR, B. Jamais fomos modernos. São Paulo: Editora 34, 1994. . Reflexão sobre o culto moderno dos deuses fe(i)tiches. Santa Catarina: Edusc, 2002.

LIMA, T. S. Para uma teoria etnográfica da distinção natureza e cultura na cosmologia juruna. RBCS. São Paulo, v.14, n.40, jun.1999. 
LOPES, José Sérgio Leite (coord.); ANTONAZ, D., PRADO, R. e SILVA, G. (org.). A Ambientalização dos conflitos sociais. Rio de Janeiro: Relume-Dumará/Núcleo de Antropologia Política/UFRJ, 2004.

. A dupla vida do acontecimento: por um realismo pragmatista. In: FRANÇA, V.; OLIVEIRA, L. (org.). Acontecimento: reverberações. Belo Horizonte: Autêntica, 2012.

PONT VIDAL, J. Acción gubernamental e institucionalismo en la Amazonia brasileña. El conflicto entorno a las infraestructuras hidroeléctricas. Estudios Sociales, v. 18, 2010.

QUÉRÉ, L. Entre o facto e sentido: a dualidade do acontecimento. In: Trajectos, n.6. Lisboa: ISCTE: Casa das Letras, 2005

SOARES, R. Um golpe de insensatez. Veja. São Paulo: n. 2062, p.4065, 28 maio 2008.

THOMAS, William. The Definition of the Situation. In:

ROUSSEAU, Nathan (ed). Lanham. Self, Symbols, and Society: Classic Readings in Social Psychology., MD: Rowman \& Littlefield, p.103-115. 2002.

VEJA. Ed. 2225. São Paulo: Abril. 13 jul. 2011.

VIVEIROS DE CASTRO, E. O Nativo Relativo. Revista Mana, v. 8, n. 1, p.113-148. 2002.

. A inconstância da alma selvagem. São Paulo: Cosac

Naify, 2011. 
. A morte como quase-acontecimento. Palestra proferida

no Café Filosófico CPFL exibido pela TV Cultura em 16/10/2009. Disponível em: <http://www.cpflcultura.com.br/site/2009/10/16/ integra-a-morte-como-quase-acontecimento-eduardo-viveiros-decastro/>

ZHOURI, A; LASCHEFSKI, K; PEREIRA, D. B. (Org.). A insustentável leveza da política ambiental: desenvolvimento e conflitos socioambientais. Belo Horizonte: Autêntica, 2005.

ZHOURI, A (org.). As tensões do lugar: hidrelétricas, sujeitos e licenciamento ambiental. Belo Horizonte, Editora UFMG, 2011.

\section{Sites Consultados}

AMAZÔNIA. Disponível em: < www.amazonia.org.br>

BLOG de Belo Monte, Norte Energia AS. Disponível em: <http:// www.blogbelomonte.com.br>

BLOG de Felício Pontes Jr., procurador MPF/PA. Disponível em: <http://belomontedeviolencias.blogspot.com>

Cobertura Completa sobre Belo Monte. Disponível em: <http:// noticias.r7.com/economia/noticias/veja-cobertura-completa-do-leilao-para-construcao-de-belo-monte-20100420.html>

Coordenação das Organizações Indígenas da Amazônia Brasileira. Disponível em: <http://www.coiab.com.br> 
INSTITUTO Socioambiental. Disponível em: <www.socioambiental.org>

MOVIMENTO dos Atingidos por Barragens. Disponível em:

$<\mathrm{http}: / /$ www.mabnacional.org.br $>$

MOVIMENTO Gota D’Água Disponível em: $<$ http://movimentogotadagua.com.br>

MOVIMENTO Xingu Vivo. Disponível em: < http://www.xinguvivo.org.br>

ORGANIZAÇÃO dos Estados Americanos. Disponível em: < www. oas.org>

PORTAL ECODEBATE. Disponível em: < www.ecodebate.com.br> PORTAL UOL. Disponível em: < www.uol.com.br> 


\section{As estratégias da Secom/PR e a construção de uma identidade brasileira no âmbito internacional}

Silvia Garcia Nogueira

Participar da "sociedade do espetáculo" atual implica em fazer o jogo social da exposição midiática, cuja principal meta é tornar-se visível. Não se trata da busca pela visibilidade em si, mas de uma administração de visibilidade diante dos outros, como analisada por Thompson (1998), na qual os jogadores tentam controlar o que e o modo como algo será dado a conhecer. Ou, nas palavras do autor, trata-se de um contínuo processo de "tomada de decisões sobre o que, a quem e como se pode tornar público” (p.125).

Tais tomadas de decisão costumam levar em consideração benefícios e riscos para o grupo que a exposição pública poderá trazer. Entre os riscos, o principal é o da perda de controle sobre a construção da imagem de si desejada, que em geral culmina na produção de um "escândalo". Este, na análise de Thompson (1998, p.130), "é um risco profissional da política na era da visibilidade mediada”. 
Tendo essa discussão como pano de fundo neste trabalho, pretende-se apresentar e analisar as estratégias utilizadas pela Secretaria de Comunicação da Presidência da República para a produção de informações sobre o "Brasil", direcionadas a formadores de opinião pública mundial, com o objetivo de influenciar as percepções do país no âmbito internacional.

Para isso, tendo como fonte uma pesquisa intitulada "A Construção Estratégica de Imagens do Brasil no Exterior: Comunicação Internacional e Política Externa na ótica da SECOM/ Presidência da República" (2010-2012) ${ }^{98}$, com apoio financeiro do $\mathrm{CNPq}$, utilizar-se-ão abordagens tanto do campo da Antropologia da Comunicação quanto das Relações Internacionais.

Trata-se, em especial, de tentar discutir que "Brasil" é esse apresentado atualmente na ótica do governo brasileiro e as dimensões políticas e culturais estratégicas presentes nesse jogo em que a utilização dos meios de comunicação de massa desempenha papel central.

\section{Opinião pública, identidade (Inter) nacional e política externa}

Os papéis desempenhados pela mídia e pela opinião pública nas relações internacionais vêm ganhando destaque no campo da Comunicação Internacional, particularmente no que se refere a sua influência em formulações de políticas externas, ao construir um ambiente social em que tais políticas são elaboradas e empreendidas.

98 Gostaria de agradecer aos profissionais da Secom/PR, incluindo-se aí a CDN, a Área Internacional e a Comunicação Pública, e especialmente a Rodrigo de Lima Baena Soares, Augusto Pestana, Jorge Duarte e Maysa Provedello, por gentilmente me atenderem e fornecerem informações preciosas para esta pesquisa. Agradeço, ainda, ao CNPq por ter apoiado financeiramente a pesquisa, viabilizando sua realização. 
Assim, os discursos midiáticos, políticos, diplomáticos, empresariais, militares e acadêmicos são essenciais na construção de representações coletivas internas e externas sobre um Estado, e a identidade nacional a ele relacionado.

Como observado por Faria (2008), sobre a relação entre opinião pública e a Política Externa Brasileira (PEB), apesar da tendência tradicional ao insulamento da formulação da política externa do país no Executivo - seguindo um padrão top down atualmente há uma "maior porosidade do processo de produção da PEB” (p.84), com a participação de novos atores, produzindo um efeito bottom up (p.85) ${ }^{99}$.

Quando o assunto é opinião pública, contudo, nem sua compreensão conceitual nem a dimensão concreta que o termo carrega são isentas de múltiplas compreensões. Para alguns, como Bourdieu (1982; 1997), cabe a pergunta se de fato ela existe ou trata-se de uma abstração. Já para Champagne (1990), trata-se de um jogo político do qual fazem parte especialistas que alimentam e constroem a crença de um povo, particularmente por meio da aplicação de pesquisas de opinião. Como lembra Scotto (2003), ambos acreditam que nos regimes democráticos, a opinião pública corresponde a um espaço social dominado por profissionais da política que disputam a definição do próprio termo.

99 Isso significa o entendimento de que outros atores sociais - como ONGs, movimentos sociais, imprensa, opinião pública, etc. - passaram a influenciar de baixo para cima (bottom up) a formulação no campo da Política Externa Brasileira, já que começaram a se interessar e a ter mais acesso aos assuntos relacionados ao campo internacional. Antes, o tema da PEB restringia-se basicamente ao Executivo e demais agentes governamentais a ele relacionados, tendo sua formulação caracterizada pela direção do tipo cima para baixo (top down), ou seja, com a formulação da PEB pelo Executivo e sem participação de outros atores sociais nesse processo. 
Ainda para Champagne (1990), nas sociedades democráticas, a "opinião pública", relacionada às elites políticas até o início do século XX, passa a ser substituída por outra "opinião pública", esta produto espontâneo dos movimentos de massa e das manifestações das ruas.

No que se refere ao que poderia ser chamado de "opinião pública mundial”, Ekekrantz (2006, p.97) ressalta que se trata de um fenômeno de "dupla face":

Primeiro, trata-se de uma construção ou projeção baseada nas necessidades legítimas, nas percepções da realidade conduzidas pela mídia, e, às vezes, media panics, entre várias elites. $\mathrm{Ou}$ melhor, opinião pública projetada de cima. Segundo, há opinião pública no sentido clássico, de baixo, isto é, para não ser associada a dados gerados pelas pesquisas de opinião. (EKEKRANTZ, 2006, p. 97).

Então, de acordo com Champagne e Ekekrantz, está embutido no próprio conceito o duplo entendimento de que tanto pode relacionar-se às elites quanto às "manifestações de rua". E, nesse sentido, fica mais claro perceber a dimensão política estratégica em torno da própria definição do que seja "a" ou "uma" opinião pública, para os agentes que integram tal disputa discursiva.

Cabe observar que o conceito adotado aqui de opinião pública é o mesmo utilizado por Manzur (1999, p.30), ou seja, um "conjunto das correntes de pensamento expressas em um país em um determinado período". A autora aponta, também, a relevância do papel desempenhado pela imprensa - que simultaneamente reflete e induz a formação de opiniões e tendências - para a construção desse conceito (p.31). 
Embora entendendo ainda que a definição da autora implica em um grande nível de abstração, é justamente por ser pouco preciso que acreditamos que ela só pode ser definida em ato, sendo construída a partir dos discursos dos agentes que falam em seu nome e referidos a situações concretas. Assim, para alguns, a opinião pública é percebida por meio de pesquisas de opinião (enquetes); para outros, por um imaginário relativamente compartilhado em relação a um assunto; e, para outros ainda, pode ser apreendida por tendências de comportamentos e práticas sociais observáveis.

De qualquer modo, perpassando a construção de um espaço social de influência sobre tais tendências e comportamentos sociais compartilhados, está a produção da visibilidade midiática em torno de assuntos e questões de interesse de diversos agentes. Isso porque, como analisado por Weber (2006, p.118), que chama a atenção para a dimensão de cálculo político - embora esta seja uma interpretação nossa - estão incluídos na visibilidade gerada pela mídia,

os votos e a formação da imagem pública, com
todas as suas consequências controladas por atuan-
tes assessorias. As relações e interesses entre política
e meios de comunicação de massa produzem uma
perversa interdependência e salutar infidelidade,
em que os interesses sociais e a ética podem ser
defendidos ou driblados, dependendo da audiência
ou do futuro da nação. (WEBER, 2006, p.118).

A interpretação da autora, assim, está em consonância com a dimensão política profissional que envolve a questão da opinião pública em sentido empírico, tal como abordado por Scotto. Para Weber (2006, p.127), "a política tem meios e investimentos sofisticados para se comunicar, para obter visibilidade, mas é no espaço público da mídia que essa visibilidade provoca credibilidade”. 
Entretanto, o espaço de visibilidade é disputado e o sucesso de sua ocupação depende de vários aspectos, segundo Weber (2006, p.132):

A natureza da instituição em relação aos interesses sociais, políticos e econômicos; estabelecimento de ações e relações com os media; a concepção estratégica da comunicação e a utilização de meios adequados a exigências e expectativas dos públicos-alvos, assim como em relação à opinião pública. Weber (2006, p.132).

A conexão entre visibilidade e credibilidade dependeria, no entanto, de ações comunicativas que envolvam a decodificação de informações:

Todas as informações (jornalísticas e publicitárias) deverão ser passíveis de decodificação, desde a sugestão de pautas para mídia impressa e eletrônica, logomarcas, peças publicitárias, material audiovisual, espaços internéticos, eventos, viagens, premiações, espetáculos, protocolos públicos até o discurso. A visibilidade deve deixar marcas, pistas atratoras para a formação da imagem pública favorável. (WEBER, 2006, p.132).

Como será visto adiante, a Secom/PR utiliza grande parte de tais recursos, listados por Weber, para participar do dinâmico processo de produção de códigos compartilhados para fins de formação de imagem pública favorável. Neste caso, na construção de uma percepção positiva de "Brasil".

Cabe observar, em consonância com Hall (2006, p.50-51), que "as culturas nacionais são compostas não apenas de instituições culturais, mas também de símbolos e representações". Como 
um discurso - "um modo de construir sentidos que influencia e organiza tanto nossas ações quanto a concepção que temos de nós mesmos" (p.51) - as culturas nacionais produzem sentidos sobre "a nação", com os quais nos identificamos.

Tais identificações no período em que vivemos - como "habitantes do líquido mundo moderno", conforme Bauman (2005, p.32) - são caracterizadas como "identidades em movimento". Assim, a Secom/PR utiliza recursos de distintas naturezas para ocupar um bom espaço de visibilidade e alcançar uma imagem positiva na construção de percepção política sobre quem o "Brasil é". Para isso, se por um lado lança mão das novas tecnologias e das mídias sociais para atingir públicos diversos, por outro, trabalha com uma ideia resiliente de identidade nacional.

\section{A Secom/Presidência da República}

A Secretaria de Comunicação Social da Presidência da República (Secom/PR), segundo Duarte (2012), divide-se em duas grandes esferas de atuação: 1) Imprensa e Porta-Voz (Presidência); 2) Comunicação Institucional (Executivo e Presidência).

Os profissionais envolvidos na primeira, que trabalham diretamente ligados à Presidência da República, atuam nos seguintes segmentos: Imprensa Nacional, Imprensa Regional, Imprensa Internacional, Monitoramento e Análise da Mídia de Comunicação, Blog do Planalto, além do Porta-Voz da Presidência.

Já na Comunicação Institucional, os profissionais dedicamse aos setores de Comunicação Pública, Comunicação para o Exterior, Internet, Planejamento, Patrocínio, Norma, Comunicação Integrada (Publicidade), Eventos.

Cabe ressaltar, conforme Jorge Duarte, coordenador do Núcleo de Comunicação Pública, em entrevista à autora (em 
08/05/2012), que se trata de uma divisão informal, baseada principalmente em uma distribuição de tarefas. O jornalista ressalta, ainda, que na Secom/PR, trabalham jornalistas, diplomatas, advogados, entre outros profissionais, e que para fazer parte do quadro a principal característica é "entender de comunicação".

Embora as funções no geral sejam preestabelecidas, há cotidianamente uma integração forte entre os profissionais da Secom/ PR. Além de executarem trabalhos conjuntos, coordenados e complementares em nível interno à própria secretaria, estão constantemente conectados a 262 órgãos - que incluem ministérios, Banco Central, Caixa Econômica, Ibama, escolas técnicas e universidades, entre outros - por meio do Sistema de Comunicação do Poder Executivo Federal (Sicom).

No que se refere à comunicação externa no âmbito internacional, foi precisamente para "promover o Brasil e a sociedade brasileira no exterior" ${ }^{100}$ que se criou em 2009, na Secom/PR, a "Área Internacional". De acordo com a própria apresentação exposta em seu site, "o que se busca é, por meio de um trabalho persistente e de longo prazo, promover o país, sua identidade, sua diversidade e suas potencialidades. A mensagem se centra na confiabilidade e na estabilidade do país" ${ }^{101}$.

Desenvolvendo um trabalho coordenado com alguns órgãos públicos e, eventualmente, com a iniciativa privada, o foco da Área Internacional (AI) da Secom/PR recai, do ponto de vista estratégico,

100 Citação retirada do site da Secretaria de Comunicação Social da Presidência da República, no item "Atribuições”, postada em: 09/11/2009 (http://www.secom.org. br). Em 2012, o site estava passando por uma reformulação. Neste caso, optou-se por trabalhar pelo que era divulgado no período de sua criação.

101 Citação retirada do site da Secretaria de Comunicação Social da Presidência da República, no item "Atribuições", postada em: 09/11/2009 (http://www.secom.org. br). 
sobre quatro eixos temáticos (denominados pela secretaria como "temas estratégicos"), que norteiam o desenvolvimento de suas atividades: "Economia", "Estabilidade Político-Institucional", "Inclusão Social" e "Meio Ambiente"102. O lema de campanha da Secom/PR, conforme explicitado em seu site103, é: "Estamos vivendo um novo Brasil. Feito por você. Respeitado pelo mundo". O objetivo é a divulgação das transformações positivas pelas quais o país passou, nos últimos anos, dentro de um "processo de crescimento econômico sustentado com desenvolvimento social”.

Os desafios aos quais estão submetidos, segundo a Secretaria, são: 1) sensibilizar para o novo patamar de desenvolvimento atingido pelo país, fortalecendo a autoestima da população; 2) demonstrar que os avanços econômicos e sociais estão presentes no dia a dia da população e refletem em vários indicadores; 3 ) destacar que o processo de construção de um país melhor continua em andamento e que é preciso se preparar para desafios ainda maiores.

Tais metas inserem-se em uma dimensão estratégica em que a divulgação de informações nos níveis doméstico e internacional ocupa na formação de uma imagem - para dentro e para fora - de quem "è" o Brasil e nas políticas implementadas a partir dessa identidade nacional construída ${ }^{104}$.

Em termos concretos, uma série de ações vem sendo empreendida nesse sentido. Entre elas, uma importante foi a realização de uma licitação, em 2008, para a contratação de uma empresa que

102 Id.,ibid

103 Id.,ibid.

104 Cabe ressaltar que a construção da imagem de uma identidade nacional quando aliada a um enfoque carregado de intenções políticas funciona como um importante capital simbólico - no sentido bourdiano do termo - que produz impactos concretos na relação de um estado com outros no âmbito internacional. 
cuidasse da divulgação do país no exterior, na qual saiu vencedora a $\mathrm{CDN}$, com um contrato de 15 milhões.

Criada em 2009, a CDN International Inc., com sede em Washington, D.C., e trabalhando com a empresa Fleishman-Hilard, é a empresa do Grupo CDN responsável por ações de comunicação corporativa nos Estados Unidos. Assim, ela desenvolve atividades de planejamento, coordenação e suporte nas áreas de assessoria de imprensa e comunicação, relações públicas e relações institucionais, objetivando criar ou fortalecer seu relacionamento com os mercados brasileiro e americano (fonte: http://www.grupocdn.com.br).

A Área Internacional da Secom/PR é formada basicamente por jornalistas da própria Secretaria, diplomatas de carreira e jornalistas da CDN. Paralelamente, ocorre ainda uma conexão com outro setor da Secom/PR, o de Comunicação Pública, mais direcionado à comunicação doméstica, ao público brasileiro. Nele, trabalham jornalistas e outros profissionais que "entendam de comunicação", segundo o coordenador do Núcleo de Comunicação Pública, Jorge Duarte.

Cabe observar que, de acordo com os que lá desempenham suas atividades, o diálogo estreito entre os envolvidos no trabalho de comunicação governamental se tornou possível na medida em que ocorreu uma mudança da política de comunicação antes fragmentada para uma percepção de que a comunicação produzida pelo governo deveria ser unificada e integrada.

Em palestra intitulada "Comunicação Social", proferida no Ciclo de Palestras da Secretaria de Assuntos Estratégicos (SAE) da Presidência da República (em 2 de setembro de 2010), o então Ministro da Secretaria de Comunicação Social da Presidência da República, Franklin Martins (2010), apresenta sua visão sobre o tema, particularmente sobre o modo como o governo trata do assunto no período compreendido entre 2007 e 2010, mas que 
podemos considerar ainda válidos pelo atual governo da presidenta Dilma Roussef.

Segundo o ministro, nesse período o governo seguiu sete princípios: 1) a comunicação deve ser integrada, de modo que o governo não produza mensagens contraditórias, já que deve compartilhar uma mesma linguagem; 2) a relação com a imprensa deve se constituir como o eixo da comunicação do governo e não a propaganda; 3) a liberdade de imprensa, uma conquista social, inclui a possibilidade de que o trabalho jornalístico deva ser criticado ou corrigido quando erra ou desinforma a população; 4) existem várias imprensas com características e necessidades distintas; 5) a publicidade do governo deve obedecer a parâmetros "técnicos, claros, transparentes, acessáveis por todos” (MARTINS, 2010, p.8); 6) nas relações com os meios de comunicação, deve haver "profissionalismo", "transparência" e "fluidez"; 7) a comunicação deve ser institucionalizada, a partir da criação de instrumentos que permaneçam no tempo, gerando "marcos legais estáveis para serem acompanhados pela população".

Junte-se a tais diretrizes governamentais a recente Lei de Acesso à Informação, de maio de 2012. De acordo com análise de Patrício e Silvestrin (2012), a Instrução Normativa n. 05/2011, publicada em 7 de junho de 2011, conceitua as ações de comunicação do Poder Executivo Federal, sendo que tais ações já estavam previstas no artigo $3^{\circ}$ do Decreto n. 7.379, de 1 de dezembro de 2010. Segundo os autores, o artigo prevê que as ações do Executivo Federal abranjam: "comunicação digital, comunicação pública, promoção, patrocínio, publicidade (classificada em de utilidade pública, institucional, mercadológica e legal), relações com a imprensa e relações públicas".

Entre as ações estratégicas de divulgação de informações pela Secom/PR estão: o programa de formadores de opinião, no qual 
jornalistas estrangeiros, intelectuais e outras pessoas consideradas influentes em termos de opinião pública mundial são convidados a conhecer de perto experiências brasileiras em vários campos (produtivo, social, ambiental, etc.); publicações; realização de seminários nacionais e internacionais, dentro e fora do país, para tratar de temáticas diversas de interesse do governo, inclusive sobre comunicação pública; uso de mídias digitais e sociais próprias, como o "Portal Brasil", twitter e facebook, entre outras.

Além disso, dentro do princípio da comunicação integrada, regularmente são realizadas reuniões com outros órgãos governamentais, especialmente com as assessorias de comunicação social ou de imprensa (embora não somente), para que se afinem os discursos, se compartilhem informações e se tracem ações conjuntas. A Área Internacional da Secom/PR, coordenada por um diplomata, costuma atuar muitas vezes em parceria com o Itamaraty/MRE e com a APEX (Agência Brasileira de Promoção de Exportações e Investimentos) para a divulgação do país no exterior.

Norteados pelos princípios da integração e da difusão é que os produtores de informações governamentais da Secom/PR são unânimes em afirmar que eles procuram dar visibilidade para ações positivas do governo, e não fazer propaganda política do governo, de governantes ou partidos, configurando o que se convencionou chamar de "chapa branca" 105 .

105 Para uma discussão sobre "comunicação chapa branca" e um ponto de vista "de dentro" da comunicação social durante o governo Lula da Silva, ver: Bucci (2008). Cabe esclarecer que este trabalho não se preocupa em verificar empiricamente se os discursos condizem com a realidade dos fatos. Antes, o que se pretende é apresentar a perspectiva da Secom/PR e de seus profissionais. 


\section{O"Brasil" e os "brasis"}

Com o título de "Por dentro do Brasil" (na versão inglesa, Brasil Insights Series), a Secom/PR produziu uma coletânea de livretos bilíngue contendo informações sobre "quem somos nós" na perspectiva econômica e política, tendo por base dados empíricos e numéricos, que são distribuídos como forma de divulgação do país dentro e fora do âmbito nacional.

A coletânea, que traz em sua capa uma espécie de mapa contendo o contorno do Brasil nas cores nacionais em destaque - como se fosse um corte de bandeira - e os perfis dos demais continentes em verde sob um fundo branco, traz os seguintes volumes: Ciência, Tecnologia e Inovação/Science, Technology and Innovation; Meio Ambiente/Environment; Eleições/Elections; Ambiente de Negócios/Business Environment; Combate ao Trabalho Análogo ao de Escravo/Fight Against Labor Analogous to Slavery; Sistema Financeiro/Financial System; Modernização da Gestão Pública/The Modernization of Public Management; Esportes/Sports; Energia/ Energy; Educação/Education.

Cada um deles representa um tema estratégico que de algum modo ajuda a construir uma percepção de quem é o Brasil no que se refere a parâmetros de "desenvolvimento real", de acordo com o diplomata da AI, Augusto Pestana, e uma jornalista da CDN/ Secom/PR, Maysa Provedello, ouvidos. Segundo eles, o Brasil apresentado não se baseia em uma divulgação "chapa branca", no sentido de ser uma representação fabricada artificialmente pelo governo brasileiro. Antes, seria um Brasil que "avançou" e cujo "avanço" deve ser divulgado.

Nas palavras do idealizador da AI da Secom/PR e ex-portavoz da Presidência da República no governo Dilma Roussef, o diplomata Rodrigo de Lima Baena Soares (em entrevista à autora 
em maio de 2011), trata-se de "modificar a percepção do Brasil no exterior, antes identificado apenas como uma terra de belas mulheres, do samba e do futebol". Para ele, "não há nenhum problema em ver o país dessa forma, o problema está em ver apenas isso" - é interessante observar que, há poucos meses, ele deixou a porta-voz da Presidência da República e passou a coordenar ações relativas às Olimpíadas de 2014.

Segundo a explicação do diplomata, a construção de uma percepção mais voltada para uma "identidade cultural brasileira" ficaria a cargo do setor cultural do Itamaraty, e de uma "identidade política e econômica" ficaria sob a responsabilidade da Secom/PR. Mas, conforme esclarece o coordenador da AI da Secom/PR, Augusto Pestana, "trabalhamos de uma forma muito integrada".

A construção da identidade internacional do Brasil, no exterior, é um tema tanto de reflexão teórica quanto serve como referencial para formulações de política externa. Para o ex-Ministro das Relações Exteriores, Celso Lafer (2009, p.19), a característica política que identifica o Brasil como um mediador externo "parte de uma visão da identidade coletiva, de um nós assinalador de especificidades. Entre estas especificidades, cabe destacar a localização geográfica no mundo, a experiência histórica, o código da língua e da cultura, os níveis e desenvolvimento e os dados de estratificação social”.

Na perspectiva adotada por Lafer, é interessante notar suas referências do que seria essa "identidade brasileira" identificando-a com o pensamento social brasileiro clássico: ele cita como referências de uma identidade nacional brasileira autores como Darcy Ribeiro, Sérgio Buarque de Holanda e Gilberto Freyre, ressaltando nosso caráter "de miscigenação, de flexibilidade, fruto de um amálgama de diferentes matrizes raciais e distintas tradições culturais".

Não é à toa que ao ser perguntado sobre que noção de "Brasil" estaria em jogo cotidianamente no desenvolvimento das atividades 
de divulgação das ações do país no exterior e da construção da percepção de uma opinião pública internacional favorável ao país em termos de "quem somos", o coordenador da AI/Secom/PR tenha respondido em uma frase: "somos um Brasil plural".

A amplitude da frase e dos sentidos que carrega do ponto de vista das possibilidades de seu uso e das definições que engendra correspondem antes a uma característica de resiliência política do que de uma percepção ingênua de "identidade nacional". Ainda que tomando emprestadas as especificidades culturais de que fala Lafer, declarações públicas de representantes do governo ressaltam um maior protagonismo brasileiro no cenário internacional.

Nesse sentido, se antes do Governo Lula da Silva (2003-2010) se tinha uma percepção política interna e externa em que a flexibilidade brasileira vinha sempre acompanhada de uma passividade política diante dos assuntos internacionais, passou-se a entender que ela agora estaria combinada a um maior protagonismo internacional.

Um exemplo que ressalta o caráter flexível, pacífico e plural brasileiro do ponto de vista das percepções externas aliado a um posicionamento mais protagônico foi o episódio da intermediação do Brasil para uma negociação entre Irã e Turquia relativa ao programa nuclear iraniano em 2010. Outro caso mais atual é o da realização da Conferência "Rio+20" que trata do desenvolvimento sustentável mundial, no Rio de Janeiro, em junho de 2012.

No caso da "Rio+20", a identificação de quem seríamos estaria atrelada ainda a uma construção de percepção de que "somos" um país que caminha em direção "ao desenvolvimento sustentável, e isso inclui o desenvolvimento ambiental, produtivo e social", segundo o coordenador da $\mathrm{AI} / \mathrm{Secom} / \mathrm{PR}$, em entrevista à autora em maio, um mês antes da conferência. Um dos modos de explicitar essa "nossa vocação" foi o convite a formadores de opinião pública 
e jornalistas estrangeiros (já comentado) para conhecerem experiências brasileiras bem-sucedidas nesse sentido. Assim, visitas a indústrias em São Paulo e a fazendas produtivas sustentáveis no Sul do país foram realizadas em 2012.

\section{Considerações finais}

O debate acadêmico e político sobre a noção de identidade apresenta entendimentos que englobam tanto a solidificação de seu conceito quanto o pressuposto de uma abstração radical que no limite significa a sua inexistência teórica ou prática. Mas, como nos lembram Bastos e Lopes (2011, p.13), "a questão da identidade tornou-se um dos grandes temas dos tempos em que vivemos" e ela se torna "uma indagação quando colocada sob suspeita".

A perspectiva adotada nesta pesquisa junto a Secom/PR é a de que a noção de identidade existe para os agentes que com ela trabalham cotidianamente ao construírem imagens e percepções de "Brasil", assim como eles utilizam o próprio termo "identidade" - e não "identificação", por exemplo. Diante disso, trabalha-se aqui como uma categoria nativa que expressa uma espécie de singularidade brasileira, mesmo que tal especificidade não seja considerada de um modo tão engessado ou sólido como a própria noção de identidade possa sugerir.

$\mathrm{O}$ entendimento do grupo pesquisado sobre o que seria a "identidade brasileira", para dentro ou para fora do país, é marcado pela resiliência que seus usos em contextos e situações concretas ou presumidas pedem politicamente. E nesse sentido, talvez a concepção em termos de práticas sociais e representacionais dos agentes governamentais se aproxime da própria concepção de Hall (2006) sobre o que seria uma identidade cultural na pós-modernidade: "formada e transformada continuamente em relação às formas pelas 
quais somos representados ou interpelados nos sistemas culturais que nos rodeiam" (p.13).

Desse modo, mesmo que o pressuposto de um caráter nacional clássico formulado por intelectuais brasileiros - que abrange traços culturais como flexibilidade, pacifismo, miscigenação e pluralidade - seja tido como referencial, a orientação governamental baseada na ideia de protagonismo político atualiza tais características em termos de intensidade e objetivos a serem cumpridos, assim como em relação aos interlocutores nacionais e internacionais do próprio governo brasileiro.

Em uma dimensão mais concreta, as informações divulgadas sobre o Brasil no exterior estão orientadas para a construção de uma percepção internacional de que o país está mais "desenvolvido" econômico, ambiental e socialmente em relação a períodos anteriores, segundo o discurso compartilhado de membros da Secom/PR.

Paralelamente, o governo vem investindo pesadamente na política de divulgação do país no Brasil e no exterior, tanto por meio da Lei de Acesso à Informação, quanto por meio da contratação da CDN que possui escritório em Washington e profissionais trabalhando diretamente na Secom/PR (em Brasilia), ou de investimentos na Empresa Brasileira de Comunicação que abrange a TV Brasil Internacional, por exemplo.

Além dessas ações, outras estratégias adotadas para melhorar as percepções do Brasil lá fora - e, portanto, construir um ambiente político internacional mais favorável - é criar situações em que os aspectos considerados positivos em relação a parâmetros internacionais possam ser dados a conhecer. Isso é feito por meio de sites governamentais, divulgação nos meios de comunicação domésticos e estrangeiros e mídias governamentais, convites realizados aos formadores de opinião mundiais para conhecer a "realidade brasileira". 
Ao trabalhar a comunicação pública nacional e internacional de modo integrado, em cima de diálogos estabelecidos entre a Secom/PR, os diversos ministérios e órgãos governamentais, além da iniciativa privada, o discurso político constrói o pressuposto identitário de um "Brasil Plural" aberto ao diálogo embora não subserviente. Se essa corresponde de fato à percepção da comunidade internacional sobre "quem somos" não é possível nem é a intenção deste trabalho dizer. No entanto, trata-se de uma concepção norteadora de políticas governamentais no campo da comunicação internacional e da política externa brasileira.

\section{Referências}

BASTOS, Liliana Cabral; LOPES, Luiz Paulo da Moita (orgs.). Introdução. In: . Estudos de identidade, entre saberes e práticas. Rio de Janeiro: Garamond, 2011.

BAUMAN, Zygmunt. Identidade. Rio de Janeiro: Jorge Zahar Ed., 2005.

BOURDIEU, Pierre. Ce que parler veut dire: l'économie des échanges linguistiques. Paris: Fayard, 1982.

. Sobre a televisão. Rio de Janeiro: Jorge Zahar Editor, 1997.

BUCCI, Eugênio. Em Brasília, 19 horas: a guerra entre a chapa -branca e o direito à informação no primeiro governo Lula. Rio de Janeiro: Record, 2008. 
CHAMPAGNE, Patrick. Faire l'opinion. Le Nouveau Jeu

Politique. Paris: Les Editions de Minuit, 1990.

EKECRANTZ, Jan. Espetáculos midiatizados e comunicações democráticas: entre a hegemonia global e a ação cívica. In: MAIA, Rousiley; CASTRO, Maria Céres Pimenta Spínola (orgs.). Mídia, esfera pública e identidades coletivas. Belo Horizonte: Editora UFMG, 2006.

FARIA, Carlos Aurélio Pimenta. Opinião pública e política externa: insulamento, politização e reforma na produção da política exterior do Brasil. Revista Brasileira de Política Internacional, v.51, n.2, p.80-97. 2008

LAFER, Celso. A identidade internacional do Brasil e a política externa brasileira. São Paulo: Perspectiva, 2009.

HALL, Stuart. A identidade cultural na pós-modernidade. 11.ed. Rio de Janeiro: DP\&A, 2006.

MANZUR, Tânia Maria P. Gomes. Opinião pública e política externa do Brasil do Império a João Goulart: um balanço historiográfico. Revista Brasileira de Política Internacional, v.42, n.1, p.30-61.1999.

MARTINS, Franklin de Souza. Ciclo de palestras: Comunicação Social. Brasília: Presidência da República/ Secretaria de Assuntos Estratégicos, Imprensa Nacional, 2010.

PATRÍCIO, Tássia Valente Viana Arouche; SILVESTRIN, Celsi Brönstrup. Comunicação no governo federal: análise da Instrução 
300 Normativa n. 05/2011 da Secretaria de Comunicação Social da Presidência da República. Revista Brasileira de Políticas de Comunicação, ed. 2, 2012. Disponível em: .....

SCOTTO, Maria Gabriela. As (difusas) fronteiras entre a política e o mercado: um estudo antropológico sobre marketing político, seus agentes, práticas e representações. PPGAS/Museu Nacional/UFRJ. Tese (Doutorado em Antropologia Social), Rio de Janeiro, 2003.

THOMPSON, John B. A mídia e a modernidade: uma teoria social da mídia. Petrópolis: Vozes, 1998.

WEBER, Maria Helena. Visibilidade e credibilidade. Tensões da comunicação política. In: MAIA, Rousiley; CASTRO, Maria Céres Pimenta Spínola (orgs.). Mídia, esfera pública e identidades coletivas. Belo Horizonte: Editora UFMG, 2006. 


\section{Sobre os autores}

ANA LUCIA ENNE é jornalista com doutorado em Antropologia pelo Programa de Pós-Graduação em Antropologia Social do Museu Nacional/Universidade Federal do Rio de Janeiro (PPGAS/MN/UFRJ). É professora da Pós-Graduação em Cultura e Territorialidades (PPCULT) da Universidade Federal Fluminense (UFF), onde coordena o Grupo de Estudos sobre Comunicação e Sociedade (GRECOS) e o Laboratório de Mídia e Identidade (LAMI). E-mail: anaenne@gmail.com.

CARLA BARROS é doutora pelo Instituto de Pós-Graduação e Pesquisa em Administração da Universidade Federal do Rio de Janeiro (COPPEAD/UFRJ), especializada em Antropologia Social pelo Museu Nacional/Universidade Federal do Rio de Janeiro (PPGAS/MN/UFRJ) e formada em Ciências Sociais pelo Instituto de Filosofia e Ciências Sociais/Universidade Federal do Rio de Janeiro (IFCS/UFRJ). Professora do Departamento de Estudos Culturais e Mídia da Universidade Federal Fluminense (UFF). Tem como principal interesse de pesquisa a área de antropologia do consumo.

CÉSAR CUNDARI DA ROCHA SANTOS possui graduação em História pela Universidade Federal do Paraná (UFPR) e pós-graduação em "Comunicação e Semiótica” pela Pontifícia 
Universidade Católica do Paraná (PUC-PR). Desde 2011, é participante do grupo "Olhares sobre a escola: educação nos discursos de entretenimento”.E-mail: cesar_ocundari@yahoo.com.br.

ISABEL TRAVANCAS é professora adjunta da graduação e do Programa de Pós- Graduação em Comunicação da Escola de Comunicação da Universidade Federal do Rio de Janeiro (ECO/ UFRJ).É jornalista, mestre em Antropologia Social pelo Programa de Pós-Graduação em Antropologia Social do Museu Nacional/ Universidade Federal do Rio de Janeiro (PPGAS/MN/UFRJ) e doutora em Literatura Comparada pela Universidade do Estado do Rio de Janeiro (UERJ). É autora dos livros: O mundo dos jornalistas (Summus Editorial, 1993), O livro no jornal (Ateliê Editorial, 2001), Juventude e televisão (FGV, 2007) e organizadora com Patrícia Farias de Antropologia e comunicação (Garamond, 2003). E-mail: isabeltravancas@yahoo.com

JANIE K. PACHECO é cientista social e mestre em Antropologia Social pela Universidade Federal do Rio Grande do Sul (UFRGS), doutoranda em Comunicação Social pela Pontifícia Universidade Católica do Rio Grande do Sul (PUC-RS) e professora da Escola Superior em Propaganda e Marketing-Sul (ESPM/ Sul). Organizadora dos Livros Juventude, Consumo \& Educação 1, 2, 3 e 4. Foi coordenadora regional do Projeto Jovem na ESPM/Sul, financiado pelo CAEPM-ESPM/SP, no período de 2009-2011. E-mail: janiekpacheco@yahoo.com.br.

JEANA LAURA DA CUNHA SANTOS é jornalista pela Universidade Federal de Santa Catarina (UFSC), mestre e doutora em Teoria Literária também pela UFSC. Autora do livro A Estética da Melancolia em Clarice Lispector e de artigos científicos para as 
revistas acadêmicas Estudos em Jornalismo e Mídia e Alceu, entre outras. Atualmente é pós-doutoranda do curso de Pós-Graduação em Antropologia Social (UFSC).E-mail: jeanasantos@terra.com.

JIMENA MARIA MASSA possui graduação em Comunicação Social pela Escuela de Ciencias de la Información da Universidad Nacional de Córdoba (UNC, Argentina) e mestrado em Antropologia Social pela Universidade Federal de Santa Catarina (UFSC). Durante o mestrado, integrou o Núcleo de Antropologia Audiovisual e Estudos da Imagem (NAVI, UFSC) e pesquisou na área de violência sexual, gênero e mídia. Foi professora de Jornalismo na Escuela de Ciencias de la Información da UNC e trabalhou como jornalista na Argentina durante 14 anos (jornais Página/12, La Mañana de Córdoba, La Nación, entre outros). Foi coordenadora editorial da revista digital da Facultad de Filosofía y Humanidades da UNC e secretária de redação da revista Vibrant da Associação Brasileira de Antropologia (ABA). Atualmente, cursa o doutorado em Antropologia Social na UFSC, onde integra o Núcleo de Identidades de Gênero e Subjetividades (NIGS) e pesquisa na área dos estudos de gênero e parentesco.

JÚLIA SCHNORR é graduada em História e mestranda em Comunicação Midiática pela Universidade Federal de Santa Maria (UFSM). Faz parte do Grupo de Pesquisa Mídia, Recepção e Consumo Cultural da UFSM e é integrante do Ponto de Cultura Espelho da Comunidade, onde desenvolve atividades no projeto "Por onde passa a memória da cidade".

LENNITA OLIVEIRA RUGGI possui graduação em Ciências Sociais pela Universidade Federal do Paraná (UFPR) e mestrado em Sociologia na mesma instituição (2005). Atualmente 
leciona Sociologia da Educação na UFPR, onde coordena o grupo "Olhares sobre a escola: a educação nos discursos de entretenimento”.E-mail: lennitaruggi@hotmail.com.

LUCIANA DE OLIVEIRA é professora adjunta do Departamento de Comunicação Social da Universidade Federal de Minas Gerais (UFMG), pesquisadora associada do Grupo de Pesquisa em Imagem e Sociabilidade (GRIS) da mesma instituição e de seu núcleo Grupo de Estudos sobre Interações em Práticas e Processos Organizacionais (GRISORG). É graduada em Publicidade e Propaganda pela Pontifícia Universidade Católica de Minas Gerais (PUC-Minas), mestre e doutora em Ciências Sociais pela UFMG. E-mail: lucianaoliveira@ufmg.br

MARCELO FRANCISCO é graduando em Ciências Sociais pela Universidade Federal do Paraná (UFPR). Integrante do grupo de pesquisa "Olhares sobre a escola: a educação nos discursos do entretenimento". Concentra sua preocupação nos estudos da sociologia da educação e da linguagem cinematográfica. E-mail: marcelosociais@gmail.com

MERCEDES CELINA CALZADO é licenciada em Ciencias de la Comunicación, Magíster en Investigación e doutora em Ciências Sociais pela Universidad de Buenos Aires (UBA). Investigadora Assistente do Consejo Nacional de Investigaciones Científicas y Técnicas (CONICET) em temas vinculados a comunicação, política e violência urbana. É membro do Instituto de Investigaciones Gino Germani e docente de carreira de Ciencias de la Comunicación da UBA. E-mail: mcalzado@sociales.uba.ar 
SILVIA GARCIA NOGUEIRA é professora do Mestrado e da Graduação em Relações Internacionais da Universidade Estadual da Paraíba (UEPB), jornalista formada pela Pontifícia Universidade Católica do Rio de Janeiro (PUC-Rio), mestre e doutora em Antropologia pelo Programa de Pós-Graduação em Antropologia Social do Museu Nacional/Universidade Federal do Rio de Janeiro (PPGAS/MN/UFRJ). Há alguns anos vem pesquisando dentro do campo da Antropologia da Comunicação, em especial de um ponto de vista dos produtores de informações. Organizou o livro América Andina: Integração Regional, Segurança e Outros Olhares (Eduepb, 2012), em conjunto com Renata Oliveira e Filipe Reis Melo, além de ter publicado artigos em diversos periódicos. E-mail: snogueirari@gmail.com

TALITA CASTRO é formada em Ciências Sociais pela Universidade Estadual de Campinas (UNICAMP), onde também concluiu seu Mestrado e atualmente cursa seu Doutorado, ambos pelo Programa de Pós-Graduação em Antropologia Social. Interessa-se pela produção de diferenças sociais e tem se dedicado ao estudo do curso da vida contemporâneo no campo da publicação editorial de autoajuda, por meio dos marcadores sociais da diferença de gênero e gerações. 
Sobre 0 livro

Projeto Gráfico e Editoração Jéfferson Ricardo Lima Araujo Nunes

Design da Capa Erick Ferreira Cabral

Revisão Linguística Elizete Amaral de Medeiros

Normalização Jane Pompilo dos Santos

\author{
Impressão Gráfica Universitária da UEPB \\ Formato $15 \times 21 \mathrm{~cm}$ \\ Mancha Gráfica $\quad 10,5 \times 16 \mathrm{~cm}$ \\ Tipologias utilizadas Arno Pro 12/14 pt \\ Futura Condensed Medium 14/ \\ $16 \mathrm{pt}$ \\ Papel Apergaminhado $75 \mathrm{~g} / \mathrm{m}^{2}$ (miolo) \\ e Cartão Supremo $250 \mathrm{~g} / \mathrm{m}^{2}$ (capa)
}

